Eng. Rodrigo Pires Leandro

\title{
ESTUDO LABORATORIAL ACERCA DA POSSIBILIDADE DE APROVEITAMENTO DA CINZA PESADA DE TERMELÉTRICA EM BASES E SUB-BASES DE PAVIMENTOS FLEXÍVEIS
}

Dissertação apresentada à Escola de Engenharia de São Carlos, Universidade de São Paulo, como parte dos requisitos para a obtenção do Título de Mestre em Engenharia Civil - Área de Concentração: Transportes.

Orientador: Prof. Dr. Glauco Tulio Pessa Fabbri 
Aos meus pais, Pedro e Marlene, ao "Vô Longe" (in memorian), à "Vó Longe" e à avó Edília (in memorian) 


\section{AGRADECIMENTOS}

Aos meus pais (Pedro e Marlene) e irmãos (Kelly, Marlon e Tatá), por todo apoio, dedicação, luta, amor e incentivo durante todos os passos da minha vida.

Ao meu avô João Pires (in memorian) e às minhas avós Regina e Edília (in memorian) por todo amor, carinho e cumplicidade.

À Karina pela ajuda na correção dos textos e, principalmente, por todo apoio, incentivo, carinho e amizade.

Ao professor Dr. Glauco Túlio Pessa Fabbri, pelos ensinamentos, conselhos, orientação e confiança depositados e ao professor Dr. Alexandre Benetti Parreira, pelo apoio e ensinamentos transmitidos.

Aos funcionários e amigos do Laboratório de Estradas do Departamento de Transportes da EESC-USP, João, Paulo e Gigante pelo companheirismo e ajuda na realização dos ensaios.

A todos os professores, alunos e funcionários do Departamento de Transportes da EESC-USP pela colaboração, paciência e amizade.

A todos meus amigos e colegas, em especial à Fernanda Biroli, Rogério Ribeiro, Lia, Shirley, Toni, Cida, João, Claudio Debeux, José Miguel, Ana Furlan, Vivi, Caio, Adriana, Andréa Helena, Kobayashi, Mané, Fábio, Celane, Adalberto, Marilda, Cynthya, Idaliria, Glene Fagundes, Higashi e Luiz Vezzaro pela amizade e apoio durante minha trajetória até aqui.

Ao CNPQ pela concessão da bolsa de estudos utilizada para a realização desta pesquisa. 


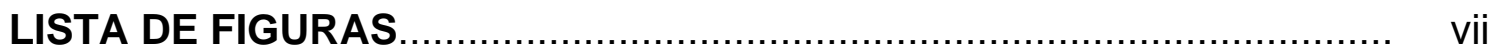

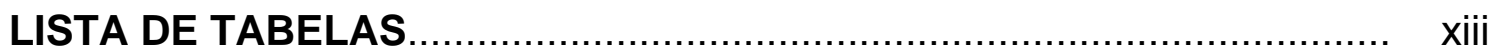

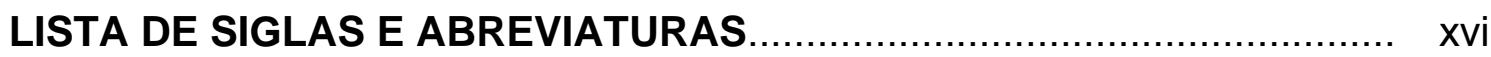

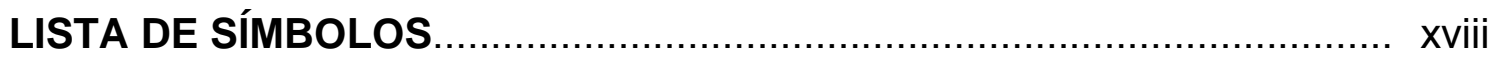

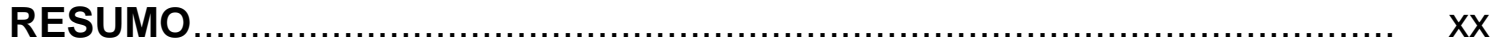

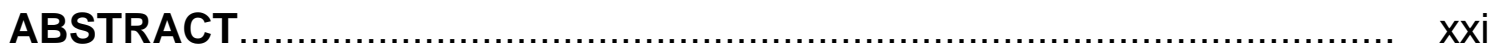

\section{CAPÍTULO 1}

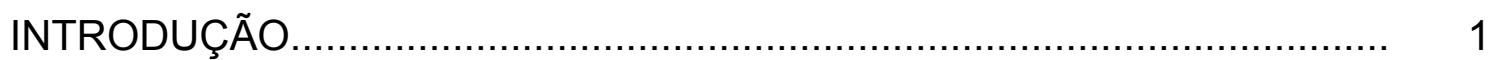

1.1 - Histórico................................................................................. 1

1.2 - Identificação do Problema........................................................ 2

1.3 - Justificativa........................................................................... 5

1.4 - Objetivo.......................................................................... 5

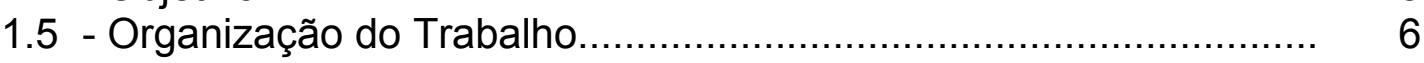

\section{CAPÍTULO 2}

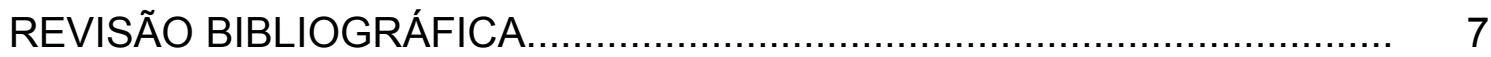

2.1 - Introdução.......................................................................... 7

2.2 - Processo de Obtenção das Cinzas Leve e Pesada........................ 8

2.3 - Cinza Pesada................................................................... 12

2.3.1 - Características químicas.......................................... 12

2.3.2 - A cinza pesada e o meio ambiente................................. 16

2.3.3 - Características físicas.................................................. 18

2.3.4 - Características mineralógicas e morfológicas.................... 23

2.3.5 - Propriedades mecânicas da cinza pesada....................... 24

2.4 - Misturas Compactadas Contendo Cinza Pesada......................... 35

2.4.1 - Cinza pesada com cimento e cinza leve........................... 35

2.4 .2 - Cinza pesada com materiais geotécnicos....................... 38 
2.5 - Utilização da Cinza Pesada na Construção Civil............................ 43

2.5.1 - Cinza pesada na produção de concretos........................... 44

2.5.2 - Cinza pesada na fabricação de artefatos de concreto......... 46

2.5.3 - Cinza pesada na fabricação de argamassas..................... 47

2.5.4 - Cinza pesada e cal hidratada em tijolos prensados............ 49

2.6 - Cal na Estabilização de Solos................................................... 51

2.6.1 - Reações solo-cal....................................................... 52

2.6.2 - Propriedades das misturas solo-cal............................... 54

2.6.2.1 - Características de compactação........................... 54

2.6.2.2 - Resistência à compressão simples....................... 55

2.6.2.3 - Resistência ao cisalhamento.............................. 56

2.6.2.4 - Módulo de elasticidade.................................... 57

2.6.3 - Métodos para determinação dos teores de cal.................. 58

2.6.4 - Relação entre as propriedades naturais dos solos e a reatividade com a cal........................................................... 60

\section{CAPÍTULO 3}

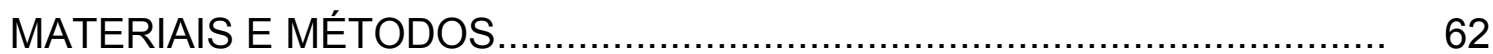

3.1 - Introdução....................................................................... 62

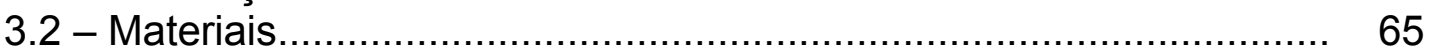

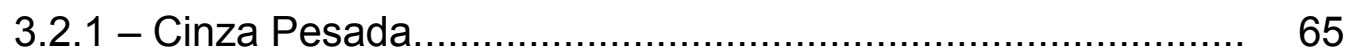

3.2.1.1 - Massa específica dos sólidos............................. 65

3.2.1.2 - Granulometria............................................ 66

3.2.1.3 - Limites de Atterberg..................................... 67

3.2.1.4 - Classificação................................................... 67

3.2 .2 - Solos................................................................... 67

3.2.2.1 - Caracterização e classificação dos solos................ 69

3.2 .3 - Cal......................................................................... 72

3.3 - Método Experimental....................................................... 73

3.3.1 - Estudo preliminar................................................ 73

3.3.1.1 - Preparo dos materiais.................................... 73

3.3.1.2 - Determinação das proporções de solo, cinza e cal.. 73

3.3.2 - Estudo definitivo......................................................... 75

3.3.2.1 - Ensaios de compressão simples......................... 75

3.3.2.2 - Ensaios de compressão diametral........................ 78

3.3.2.3 - Cálculo do intercepto coesivo e do ângulo de atrito através dos resultados de RCS e RCD............................. 81

3.3.2.4 - Ensaios de CBR ......................................... 82

3.3.2.5 - Cura dos corpos-de-prova................................ 83

3.3.2.6 - Análise dos resultados.................................... 83

\section{CAPÍTULO 4}

APRESENTAÇÃO E DISCUSSÃO DOS RESULTADOS......................... 85

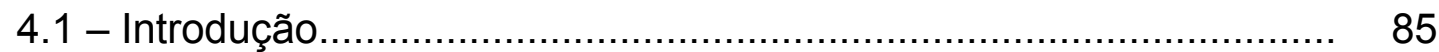

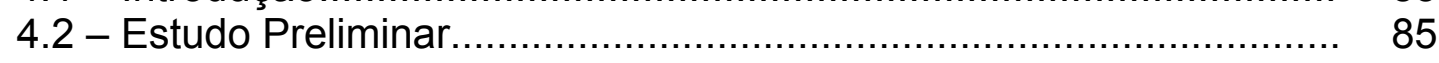


4.2.1 - Ensaios de Mini-CBR ..................................................... 86

4.3 - Estudo Definitivo.............................................................. 90

4.3.1 - Resistência à compressão simples..................................... 90

4.3.2 - Módulo tangente inicial................................................. 97

4.3.2.1 - Influência das adições de cinza, cal e do período de cura no módulo tangente inicial das misturas................... 98

4.3.2.2 - Comparação da resistência à compressão simples e módulo tangente inicial.................................................. 103

4.3.3 - Resistência à tração por compressão diametral................. 107

4.3.3.1 - Comparação das resistências à compressão simples e à tração por compressão diametral........................ 114

4.3.4 - Intercepto coesivo e ângulo de atrito das misturas solocinza e solo-cinza-cal............................................................. 118

4.3.5 - Resultados dos ensaios de CBR.................................... 128

4.3.5.1 - Influência das adições de cinza pesada e da cal sobre o CBR das misturas solo-cinza e solo-cinza-cal.

4.3.5.2 - Influência das adições de cinza e da cal sobre a expansão das misturas de solo-cinza e solo-cinza-cal.

4.3.6 - Resistência à compressão simples na condição imersa das misturas solo-cinza e solo-cinza-cal aos 7 dias de cura.

\section{CAPÍTULO 5}

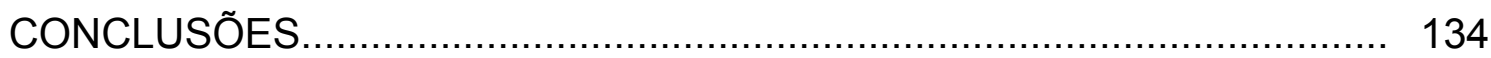

RECOMENDAÇÕES PARA TRABALHOS FUTUROS............................. 139

REFERÊNCIAS BIBLIOGRÁFICAS................................................... 141

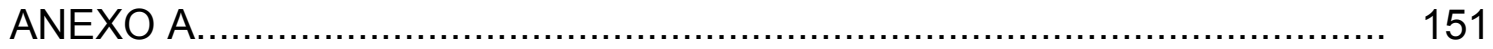

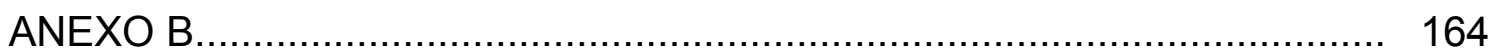

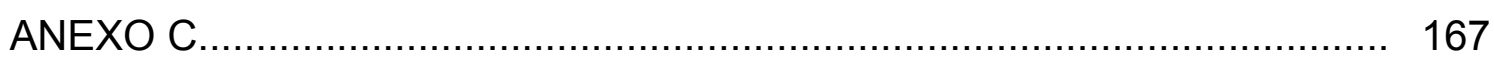

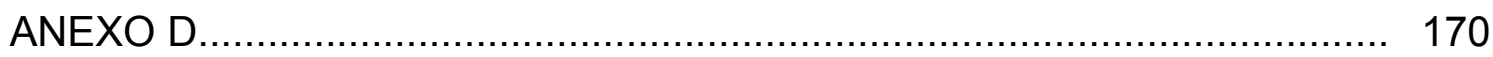




\section{LISTA DE FIGURAS}

FIGURA 1.1 - Bacias de sedimentação de cinzas do Complexo Termelétrico Jorge Lacerda...

FIGURA 2.1 - Esquema de geração de energia térmica e produção das cinzas (TRACTEBEL ENERGIA, 2002).

FIGURA 2.2 - Faixa granulométrica das cinzas pesadas estudadas por Lovell et al. (1991) e distribuições granulométricas das cinzas pesadas da Usina Termelétrica Jorge Lacerda (ROCHA, 2001; LEANDRO, 2002).

FIGURA 2.3 - Variação das curvas granulométricas de três cinzas pesadas coletadas em diferentes épocas (LOVELL et al., 1991)

FIGURA 2.4 - Curvas de compactação típicas das cinzas pesadas (LOVELL et al., 1991).

FIGURA 2.5 - Variação do CBR com o teor de umidade de compactação e condição de saturação das amostras compactadas (adaptado de LOVELL et al., 1991).

FIGURA 2.6 - Ângulo de atrito "versus" massa específica seca de cinzas pesadas resultantes dos processos de queima MB e RDF (PANDELINE et al., 1997).

FIGURA 2.7 - Curvas deformação axial "versus" tensão desvio das cinzas pesadas resultantes dos processos de queima $\mathrm{MB}$ e RDF (PANDELINE et al., 1997).

FIGURA 2.8 - Curvas de deformação axial "versus" deformação volumétrica das cinzas pesadas resultantes dos processos de queima MB e RDF (PANDELINE et al., 1997)

FIGURA 2.9 - Resistência à compressão simples "versus" teor de umidade das cinzas pesadas resultantes dos processos de queima MB e RDF (PANDELINE et al., 1997). 
FIGURA 2.10 - Trajetória de tensões da cinza pesada e de um material granular sob carregamento repetido (NUNES e DAWSON, 1997).

FIGURA 2.11 - Resistência à compressão simples dos materiais submetidos a carregamento triaxial (NUNES e DAWSON, 1997)

FIGURA 2.12 - Módulo de resiliência dos materiais estudados por Nunes e Dawson, 1997

FIGURA 2.13 - Massas específicas secas máximas em função do teor e do tipo de cinza nas misturas (KSAIBATI e BOWEN, 1999)

FIGURA 2.14 - Teores ótimos de umidade em função do teor de cinza e do tipo nas misturas (KSAIBATI e BOWEN, 1999)

FIGURA 2.15 - Valores de "cohesion value" (CV - Value) em função do teor de cinza e do tipo nas misturas (KSAIBATI e BOWEN, 1999).

FIGURA 2.16 - Variação dos R - Value com a adição de cinza pesada ao material granular (KSAIBATI e BOWEN, 1999).

FIGURA 2.17 - Resistência à compressão simples de concretos com substituição da areia por cinza pesada (ROCHA et al., 2001)

FIGURA 2.18 - Resistência à compressão dos concretos com substituição do cimento Portland por cinza pesada (ROCHA et al., 2001).....

FIGURA 2.19 - Resistência à compressão simples de blocos estruturais com substituição do cimento Portland pela cinza pesada (ROCHA et al., 1999).

FIGURA 2.20 - Resistência à compressão simples das argamassas de cimento-areia e cimento-cinzas (adaptado de PIAZZA e RUI, 1999).

FIGURA 2.21 - Resistência à tração por flexão das argamassas de cimento-areia e cimento-cinzas (adaptado de PIAZZA e RUI, 1999).

FIGURA 2.22 - Exemplo de comportamento tensão deformação do solo natural e do solo tratado com cal (TRB, 1987)

FIGURA 3.1 - Fluxograma das etapas do estudo experimental. 
FIGURA 3.2 - Localização da Usina Termelétrica Jorge Lacerda

65

FIGURA 3.3 - Distribuição granulométrica da cinza pesada empregada no presente estudo e a obtida por Leandro (2002)

FIGURA 3.4 - Localização dos pontos de coleta das amostras de solo e de cinza pesada

FIGURA 3.5 - Perfis dos solos provenientes de: Treze de Maio (TM), Sangão (SG) e Jaguaruna (JG).

FIGURA 3.6 - Distribuição granulométrica dos solos coletados na área de estudo.

FIGURA 3.7 - Posição dos solos no ábaco de classificação MCT.

FIGURA 3.8 - Exemplo de nomenclatura adotada para distinguir as misturas dos três solos com os vários teores de cinza e também com a cal.

FIGURA 3.9 - Exemplo da estimativa de $E_{0}$ a partir da determinação do coeficiente "a" (adaptado de DUCAN e CHANG, 1970)......

FIGURA 3.10 - Exemplo da estimativa de $E_{0}$ a partir da curva tensão $x$ deformação.

FIGURA 3.11 - Esquema de distribuição de tensões no ensaio de compressão diametral ou Ensaio Brasileiro.

FIGURA 3.12 - Comparação entre o critério de ruptura empírico e o critério de ruptura de Mohr Coulomb.

FIGURA 3.13.- Esquema do traçado dos círculos de Mohr Coulomb a partir dos resultados dos ensaios de compressão simples e compressão diametral para determinação do intercepto coesivo (c) e do ângulo de atrito $(\varnothing)$.

FIGURA 4.1 - Curvas de compactação das misturas do solo JG com cinza pesada.

FIGURA 4.2 - Massa específica seca máxima das misturas de solocinza em função do teor de cinza pesada.

FIGURA 4.3 - Teor de umidade ótimo das misturas de solo-cinza em função do teor de cinza pesada.

FIGURA 4.4 - Variação das resistências à compressão simples imediatas das misturas solo-cinza em função do teor de cinza pesada. 
FIGURA 4.5 - Resistência à compressão simples em função do período de cura das misturas do solo laterítico TM com cinza pesada.

FIGURA 4.6 - Resistência à compressão simples imediata em função do teor de cinza pesada das misturas do solo TM com cinza pesada e cal em comparação com as misturas desse solo com apenas cinza.

FIGURA 4.7 - Resistência à compressão simples em função do período de cura para as misturas do solo JG com cinza pesada e cal.

FIGURA 4.8 - Variação do módulo tangente inicial imediato das misturas de solo-cinza em função do teor de cinza pesada

FIGURA 4.9 - Variação do módulo tangente inicial em função do período de cura para as misturas do solo laterítico JG com cinza pesada.

FIGURA 4.10 - Variação do módulo tangente inicial imediato das misturas de solo-cinza-cal em função do teor de cinza pesada em comparação com as misturas solo-cinza do solo TM na condição sem cura

FIGURA 4.11 - Variação do módulo tangente inicial aos 84 dias de cura das misturas de solo-cinza-cal em função do teor de cinza pesada em comparação com as misturas solo-cinza do solo TM.

FIGURA 4.12 - Variação do módulo tangente inicial das misturas de solocinza-cal do solo JG em função do tempo de cura.

FIGURA 4.13 - Resistência à compressão simples versus módulo tangente inicial das misturas de solo-cinza.

FIGURA 4.14 - Resistência à compressão simples versus módulo tangente inicial das misturas de solo-cinza-cal.

FIGURA 4.15 - Variação percentual das resistências à compressão simples e módulo tangente inicial das misturas de solocinza devido à adição de $3 \%$ de cal sem cura prévia.

FIGURA 4.16 - Variação percentual das resistências à compressão simples e módulo tangente inicial das misturas de solocinza devido à adição de $3 \%$ de cal aos 28 dias de cura....

FIGURA 4.17 - Variação percentual das resistências à compressão simples e módulo tangente inicial das misturas de solo- 106 
cinza devido à adição de $3 \%$ de cal aos 84 dias de cura....

FIGURA 4.18 - Resistência à tração por compressão diametral das misturas de solo-cinza em função do teor de cinza aos 28 dias de cura.

FIGURA 4.19 - Resistência à tração por compressão diametral das misturas do solo laterítico JG com cinza pesada em função do período de cura.

FIGURA 4.20 - Resistência à tração por compressão diametral das misturas do solo não laterítico SG com cinza pesada em função do período de cura.

FIGURA 4.21 - Resistência à tração por compressão diametral das misturas do solo JG com cinza e cal e das misturas desse solo apenas com cinza na condição sem cura em função do teor de cinza pesada.

FIGURA 4.22 - Resistência à tração por compressão diametral das misturas do solo JG com cinza e cal e das misturas desse solo com apenas cinza aos 84 dias de cura em função do teor de cinza pesada

FIGURA 4.23 - Resistência à tração por compressão diametral das misturas do solo SG com cinza pesada e cal em função do período de cura

FIGURA 4.24 - Resistência à compressão simples versus resistência à tração por compressão diametral das misturas de solocinza

FIGURA 4.25 - Resistências à compressão simples versus resistência à tração por compressão diametral das misturas de solocinza-cal.

FIGURA 4.26 - Variação percentual das resistências à compressão simples e à tração por compressão diametral das misturas de solo-cinza devido à adição de $3 \%$ de cal sem cura prévia.

FIGURA 4.27 - Variação percentual das resistências à compressão simples e à tração por compressão diametral das misturas de solo-cinza devido à adição de $3 \%$ de cal aos 28 dias de cura.

FIGURA 4.28 - Variação percentual das resistências à compressão simples e à tração por compressão diametral das misturas de solo-cinza devido à adição de $3 \%$ de cal aos 84 dias de cura. 
FIGURA 4.29 - Intercepto coesivo aos 84 dias de cura das misturas de solo-cinza em função do teor de cinza pesada..

FIGURA 4.30 - Intercepto coesivo sem cura prévia das misturas do solo SG com cinza e cal em comparação com as misturas desse solo com apenas cinza pesada.

FIGURA 4.31 - Intercepto coesivo das misturas do solo JG com cinza pesada em função do período de cura

FIGURA 4.32 - Intercepto coesivo das misturas do solo JG com cinza pesada e cal em função do período de cura.

FIGURA 4.33 - Variação do ângulo de atrito das misturas solo-cinza aos 28 dias de cura em função do teor de cinza pesada.

FIGURA 4.34 - Variação do ângulo de atrito das misturas solo-cinza-cal aos 28 dias de cura em função do teor de cinza pesada....

FIGURA 4.35 - Influência da adição de 3\% de cal às misturas do solo TM com cinza pesada aos 28 dias de cura.

FIGURA 4.36 - Variação do ângulo de atrito das misturas do solo TM com cinza pesada em função do período de cura.

FIGURA 4.37 - Variação do ângulo de atrito das misturas do solo TM com cinza pesada e cal em função do período de cura.

FIGURA 4.38 - Variação do CBR em função do teor de cinza pesada para as misturas de solo-cinza e solo-cinza-cal.

FIGURA 4.39 - Resistência à compressão simples versus teor de cinza pesada nas condições imersa e não imersa das misturas de solo-cinza e solo-cinza-cal. 


\section{LISTA DE TABELAS}

TABELA 1.1 - Utilização aproximada dos resíduos da combustão de carvão (ZWONOK et al'., 1996 apud POZZOBOM, 1998).

TABELA 2.1 - Composição química de cinzas pesadas americanas (FEDERAL HIGHWAY ADMINISTRATION, 1998)

TABELA 2.2 - Composição química de cinzas pesadas provenientes de diferentes usinas do estado de Indiana (LOVELL et al., 1991) e da cinza pesada da Usina Jorge Lacerda, Santa Catarina (NARDI, 1988 e ROCHA, 1999).

TABELA 2.3 - Corrosividade das cinzas pesadas do estado americano de Indiana (KE e LOVELL et al., 1992).

TABELA 2.4 - Análise toxicológica das cinzas pesadas (LOVELL et al., 1991; DESCHAMPS, 1997).

TABELA 2.5 - Ensaios de Lixiviação das Cinzas Pesadas (LOVELL et al., 1991; DESCHAMPS, 1997).

TABELA 2.6 - Distribuição granulométrica típica das cinzas pesadas de três usinas térmicas de West Virginia (FEDERAL HIGHWAY ADMINISTRATION, 1998).

TABELA 2.7 - Variação de massa específica dos sólidos das cinzas pesadas

TABELA 2.8 - Faixa dos valores de CBR das cinzas pesadas americanas (LOVELL et al., 1991).

TABELA 2.9 - Degradação granulométrica das cinzas pesadas sob compactação e abrasão "Los Angeles" (adaptado de LOVELL et al., 1991).

${ }^{1}$ ZWONOK, O., CHIES, F., SILVA, N. I. W. (1996). Identificação dos usos possíveis para as cinzas carboníferas de termelétricas brasileiras. Relatório ELETROBRÁS. Porto Alegre, CIENTEC. 88p. 
TABELA 2.10 - Porcentagens de cimento, cal e cinza leve utilizados na estabilização de materiais (NUNES e DAWSON, 1997)..

TABELA 2.11 - Porcentagens de cinzas pesadas utilizadas nas misturas com agregado convencional e respectivos valores de absorção de água (KSAIBATI e BOWEN, 1999).

TABELA 2.12 - Resistência à compressão simples dos tijolos com 10\% de cal e $90 \%$ de cinza pesada (CHIES et al., 1998).......

TABELA 3.1 - Resultados dos ensaios de massa específica dos sólidos e dos Limites de Atterberg para os solos estudados.

TABELA 3.2 - Porcentagens de areia, silte e argila dos solos estudados.

TABELA 3.3 - Classificação dos solos segundo os métodos MCT, HRB, USCS e atividade dos argilo-minerais em função do CA

TABELA 3.4 - Propriedades da cal cálcica, Supercal CH-III.

TABELA 3.5 - Proporções de solo, cinza pesada e cal empregadas em cada mistura para cada tipo de solo

TABELA 4.1 - Resultados de mini-CBR imediato, mini-CBR após 24 horas de imersão, expansão e contração para a massa específica seca máxima e teor de umidade ótimo das misturas de solo-cinza.

TABELA 4.2 - Resistência à compressão simples dos solos e das misturas de solo-cal, solo-cinza e solo-cinza-cal para todos os períodos de cura.

TABELA 4.3 - Módulo tangente inicial dos solos e das misturas de solo-cal, solo-cinza e solo-cinza-cal para todos os períodos de cura.

TABELA 4.4 - Resistência à tração por compressão diametral dos solos puros e das misturas de solo-cal, solo-cinza e solo-cinza-cal para todos os períodos de cura..

TABELA 4.5 - Intercepto coesivo dos solos e das misturas de solo-cal, solo-cinza e solo-cinza-cal para todos os períodos de cura. 
TABELA 4.6 - Ângulo de atrito dos solos e das misturas de solo-cal, solo-cinza e solo-cinza-cal para todos os períodos de

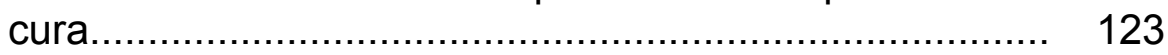

TABELA $4.7-\quad$ CBR das misturas de solo-cinza e solo-cinza-cal............ 128

TABELA 4.8 - Expansão das misturas de solo-cinza e solo-cinza-cal.... 131 


\section{LISTA DE SIGLAS E ABREVIATURAS}

AASHTO - American Association of State Highway and Transportation Officials ABNT - Associação Brasileira de Normas Técnicas

AFBC - Atmospheric Fluidized Bed Combustion

CA - Coeficiente de Atividade

CBR - California Bearing Ratio

DER/SP - Departamento de Estradas de Rodagem do Estado de São Paulo

DNER - Departamento Nacional de Estradas de Rodagem

EESC - Escola de Engenharia de São Carlos

EP - Extração toxicológica

EPA - Environmental Protection Agency

FHWA - Federal Highway Administration

HRB - Highway Research Board

LVDT - Linear Variable Differential Transducers

MB - Mass Burn

MCL - Maximum contaminant levels

MCT - Miniatura, Compactado, Tropical

MWC - Municipal waste combustor

RCS - Resistência à Compressão Simples

RCD - Resistência à Compressão Diametral

RTCD - Resistência à Tração por Compressão Diametral 


\author{
RDF - Refuse Derived Fuel \\ TRB - Transportation Research Board \\ USP - Universidade de São Paulo \\ USCS - Unified Soil Classification System \\ UTLC - Usina Termelétrica Jorge Lacerda - Unidade C
}




\section{LISTA DE SÍMBOLOS}

a - Constante de regressão

$\mathrm{Al}_{2} \mathrm{O}_{3}$ - Óxido de alumínio

b - Constante de regressão

c - Intercepto coesivo

CaO - Óxido de cálcio

$\mathrm{Ca}(\mathrm{OH})_{2}-$ Hidróxido de Cálcio

CCS2 - Areia argilosa com $2 \%$ de cimento e $8 \%$ de cinza leve

CCS4 - Areia argilosa com $2 \%$ de cimento

CCS6 - Areia argilosa

$E_{0}$ - Módulo tangente inicial

$\varepsilon_{a}-$ Deformação axial

$\varepsilon_{R}-$ Deformação resiliente

FBA3 - Cinza pesada com $2 \%$ de cimento e $8 \%$ de cinza leve

FBA4 - Cinza pesada com $2 \%$ de cimento

$\mathrm{Fe}_{2} \mathrm{O}_{3}-$ Óxido Férrico

GRA1 - Granito Britado

$\mathrm{h}_{0}-$ Altura inicial

$\Delta \mathrm{h}$ - Deslocamento resiliente

JG - Jaguaruna

$\mathrm{K}_{2} \mathrm{O}$ - Óxido de potássio

MIN1 - Minestone com 5\% de cal

MIN4 - Minestone com 3\% de cal e 12\% de cinza leve

$M_{R}-$ Módulo de resiliência

$\mathrm{MgO}$ - Óxido de magnésio

$\mathrm{MnO}$ - Óxido de manganês

$\mathrm{Na}_{2} \mathrm{O}$ - Óxido de sódio 
$\mathrm{P}_{2} \mathrm{O}_{5}$ - Óxido de fósforo

PFA2 - Cinza leve com $2 \%$ de cimento

PFA3 - Cinza leve com $5 \%$ de cimento

$\mathrm{pH}$ - Logaritmo negativo da concentração hidrogeniônica

PV - Podzólico vermelho amarelo

$r$ - resistividade

SG - Sangão

$\mathrm{SiO}_{2}$ - Óxido de silício

$\mathrm{SO}_{3}$ - Óxido de enxofre

SW1 - Resíduos de ardósia

$\sigma_{3}-$ Tensão confinante

$\sigma_{a}-$ Tensão axial

$\sigma_{c}-$ Tensão de contato

$\sigma_{d}-$ Tensão desvio

TM - Treze de Maio

$\rho_{\mathrm{dmax}}$ - Massa específica seca máxima

$\mathrm{w}_{\mathrm{o}}$ - Teor de umidade ótimo

$\phi$ - Ângulo de atrito interno 


\title{
RESUMO
}

\begin{abstract}
LEANDRO, R. P. (2005). Estudo Laboratorial Acerca da Possibilidade de Aproveitamento da Cinza Pesada de Termelétrica em Bases e Sub-bases de Pavimentos Flexíveis. São Carlos 2005. 172p. Dissertação de Mestrado. Escola de Engenharia de São Carlos - Universidade de São Paulo.
\end{abstract}

A cinza pesada é um sub-produto gerado do processo da queima do carvão mineral pulverizado nas caldeiras das termelétricas para a produção de vapor aquecido que atuará na geração de energia elétrica. Não há um destino adequado para esse tipo de cinza, sendo que o volume gerado diariamente é depositado em bacias de sedimentação, causando, dessa forma, problemas ambientais. Principalmente nos Estados Unidos, muitas pesquisas têm evidenciado o sucesso do emprego deste resíduo na construção de rodovias. Contudo, no Brasil as pesquisas sobre cinza pesada estão mais voltadas para a área de edificações. Deste modo, a proposta da pesquisa foi investigar os efeitos da cinza pesada quando incorporada a solos, através de ensaios laboratoriais, visando o aproveitamento deste resíduo na construção de bases e sub-bases de pavimentos. Também foi avaliado o efeito da adição de cal às misturas solo-cinza. Os ensaios utilizados na etapa experimental foram os de mini-CBR, resistência à compressão simples e resistência à tração por compressão diametral. Complementarmente, realizaram-se ensaios de CBR e de resistência à compressão simples na condição imersa. Os resultados mostraram que as adições de cinza pesada aos solos não melhoram as propriedades mecânicas das misturas compactadas. Entretanto, a adição de $3 \%$ de cal às misturas de solo-cinza proporciona a melhora significativa no comportamento mecânico das misturas, oferecendo uma solução para aproveitamento da cinza pesada na construção rodoviária.

Palavras-chave: Resíduo, cinza pesada, cal, pavimento. 


\title{
ABSTRACT
}

\begin{abstract}
LEANDRO, R. P. (2005). Laboratory Study Concerning the Possible Utilization of the Bottom Ash from Thermal Power Station in the Bases and Sub-bases of Pavements. São Carlos 2005. 172p. Master in Science Thesis. Escola de Engenharia de São Carlos - Universidade de São Paulo.
\end{abstract}

Bottom ash is a by-product from the burning of mineral coal. It is utilized as fuel in thermal power stations in order to produce electrical energy. The bottom ashes are deposited in the lagoons and are harmful to the environment. In the United States, several researches have indicated successful uses of this waste in the construction of roadways. However, in Brazil the researches have been accomplished to use the bottom ashes in the civil construction. Thus, the purpose of the present research was to investigate the results of the bottom ash additions to soil in order to utilization in bases and sub-bases of pavements. Afterward, the effects of lime additions to soil-bottom ash mixtures were evaluates. The tests employded were mini-CBR, unconfined compressive strength and indirect tensile strength. California Bearing Ratio and immersion unconfined compressive strength were accomplish such supplementary tests. The results indicated that bottom ash additions to soils does not improve the mechanical properties of the compacted mixtures. However, the addition of the $3 \%$ of the lime to soil-bottom ash mixtures provided better mechanical performance, offering a feasible solution for the use of this waste in road construction.

Keywords: Wastes, bottom ash, lime, pavement. 


\section{CAPÍTULO 1}

INTRODUÇÃO

\section{1 - HISTÓRICO}

O emprego de cinzas na construção civil não é uma técnica nova. Há 2000 anos, os romanos já conheciam as propriedades pozolânicas das cinzas vulcânicas e faziam seu uso na construção de moradias, templos e monumentos; o Coliseum e o Pont du Gard são exemplos da utilização de cinza.

Os romanos elaboravam uma mistura de cinza vulcânica e cal para conseguir uma pasta cimentante. A sílica ativa e a alumina, presentes nas cinzas, combinadas com a cal e com a água originavam uma pasta com propriedades pozolânicas. A palavra "pozolana" deriva do nome da vila de Pozzuoli, localizada no interior da Itália, próxima ao Vulcão Vesúvio, região onde a cinza era usada com freqüência e denota a importância deste material na construção civil desde aquela época.

Com a industrialização, surgiram processos rudimentares de queima de carvão para geração de energia. No inicio, o carvão era queimado em torrões sobre grelhas dentro das câmaras de combustão, gerando, além de energia mecânica ou elétrica, um resíduo conhecido como cinder (escória). As empresas geradoras de energia térmica freqüentemente empregavam o cinder como revestimento granular sobre as estradas de terra em substituição ao cascalho. 
A modernização e a implantação de processos de queima de carvão mineral mais eficientes, nas usinas térmicas, aconteceram na década de 1920. Os novos processos consistiam em queimar o carvão mineral pulverizado nas caldeiras ao invés de torrões. Assim, o cinder deu lugar à geração de dois resíduos mais finos e tão ou mais prejudiciais ao meio ambiente: a cinza leve e a cinza pesada.

Nesta época, as cinzas resultantes dos novos processos de combustão do carvão mineral não despertavam qualquer interesse. Somente com o decorrer dos anos, as propriedades cimentantes e pozolânicas das cinzas foram reconhecidas e passaram a ser estudadas por vários pesquisadores, elevando o "status" da cinza de um simples resíduo ao de um sub-produto de interesse econômico.

\section{2 - IDENTIFICAÇÃO DO PROBLEMA}

As pesquisas direcionadas ao aproveitamento das cinzas tornaram possível o emprego desses materiais na construção civil e, sobretudo, na fabricação do cimento Portland pozolânico. Contudo, como o consumo de cinzas sempre foi muito menor que sua produção, o material não utilizado é depositado a céu aberto em grandes bacias de sedimentação até hoje.

Em 1971, nos Estados Unidos, foram geradas 27.751.054 t de cinza leve e 10.058.967 t de cinza pesada. Entretanto, apenas $3.738 .488 \mathrm{t}$, cerca de $13 \%$, de cinza leve e $1.612 .026 \mathrm{t}$, ou $16 \%$, de cinza pesada foram utilizadas. $\mathrm{O}$ restante foi descartado em bacias de sedimentação (TORREY, 1978). A tabela 1.1 apresenta o percentual de aproveitamento dos resíduos da combustão do carvão nos cinco continentes. 
TABELA 1.1 - Utilização aproximada dos resíduos da combustão de carvão (ZWONOK et al'., 1996 apud POZZOBOM, 1998).

\begin{tabular}{|c|c|}
\hline Continente & Percentual de Aproveitamento (\%) \\
\hline Europa & 42,5 \\
\hline Ásia & 30,0 \\
\hline América & 27,5 \\
\hline África & 19,0 \\
\hline Oceania & 10,5 \\
\hline
\end{tabular}

Nas últimas décadas, a reciclagem de resíduos industriais ganhou especial importância devido aos altos custos de disposição e, principalmente, devido às exigências impostas pelos órgãos reguladores. Por outro lado, o crescente desenvolvimento industrial da sociedade tem provocado o aumento do consumo de energia elétrica. Para suprir essa maior demanda novas fontes e, sobretudo novos projetos de usinas geradoras estão previstos e, dentre estes, têm-se as termelétricas a carvão, que produzem energia mediante a queima do carvão mineral pulverizado nas caldeiras de combustão.

No Brasil, a produção de cinza pesada, oriunda da queima do carvão mineral está concentrada na região Sul, sobretudo no estado de Santa Catarina e Rio Grande do Sul. Somente no Estado de Santa Catarina, a produção anual de cinzas alcança $818.000 \mathrm{t}$, sendo que $30 \%$ desse total, aproximadamente $245.400 \mathrm{t}$, é correspondente à cinza pesada, (ROCHA et al., 1999). Nos Estados Unidos, a produção de cinza pesada no ano de 1996 alcançou 16.100.000 t (FEDERAL HIGHWAY ADMINISTRATION, 1998). Com o aumento da demanda de energia elétrica e com a perspectiva de instalação de novas usinas térmicas a carvão, conseqüentemente ocorrerá um aumento na produção de cinzas.

A cinza leve, por ser um material finamente dividido e apresentar boa atividade pozolânica, é empregada em vários ramos da construção civil em todo o mundo: construção de barragens e aterros rodoviários, estabilização de solos, fabricação de tijolos, telhas, artefatos de cimento (blocos estruturais, blocos de vedação e blocos para pavimentação), como aditivo em concretos,

${ }^{2}$ ZWONOK, O, CHIES, F., SILVA, N. I. W. (1996). Identificação dos usos possíveis para as cinzas carboníferas de termelétricas brasileiras. Relatório ELETROBRÁS. Porto Alegre, CIENTEC. 88p. 
além de também ser usada como fertilizante. No Brasil, a cinza leve é quase que totalmente utilizada na fabricação do cimento Portland pozolânico e na confecção de concretos.

Nos Estados Unidos, a cinza pesada é empregada com sucesso na construção rodoviária desde a década de 50 , além de ser utilizada também na fabricação de blocos de concreto, drenos de rodovias e aterros. Entretanto, no Brasil, a cinza pesada não tem tido o mesmo aproveitamento, sendo o material quase que totalmente descartado a céu aberto nas bacias de sedimentação, constituindo risco ambiental e, por isso, comprometendo a instalação de novas unidades geradoras de energia térmica.

A disposição das cinzas a céu aberto exige grandes áreas para a construção das bacias que, por sua vez, têm capacidade limitada. Além disso, o resíduo fica exposto a processos de lixiviação de metais pesados presentes nas cinzas, podendo contaminar o solo e o lençol freático da região. Outro problema desse método de descarte é a poeira silicosa, resultante da ação do vento sobre a superfície das bacias, que atinge a população residente próximo a essas instalações.

A figura 1.1 mostra algumas das bacias de sedimentação de cinzas da Usina Termelétrica Jorge Lacerda, utilizadas para disposição final do resíduo. A maior bacia desse complexo termelétrico tem capacidade de armazenamento de aproximadamente $720.000 \mathrm{~m}^{3}$ de cinza pesada.

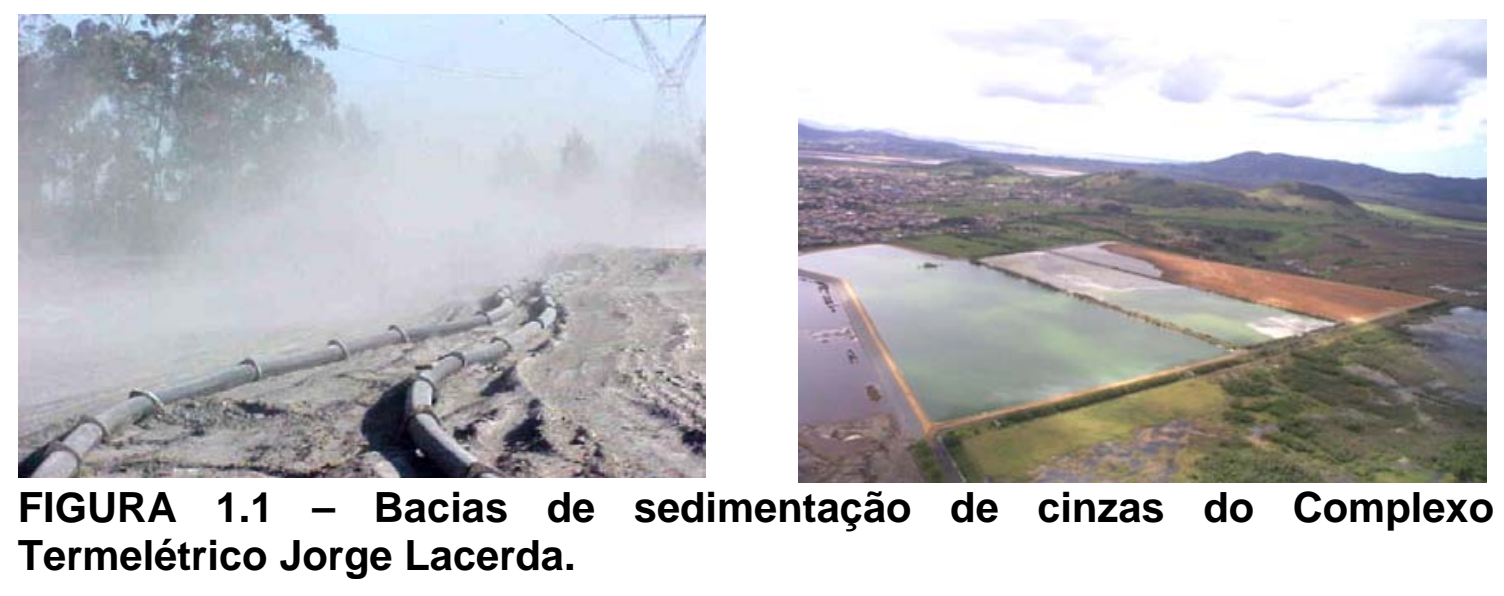




\section{3 - JUSTIFICATIVA}

A cinza pesada produzida na região Sul do Brasil, principalmente no Complexo Termelétrico Jorge Lacerda, em Santa Catarina, não tem tido qualquer tipo de aproveitamento, ficando depositada a céu aberto, caracterizando potencial risco ambiental.

Ao contrário do que ocorre em outros países, a maioria das pesquisas desenvolvidas no Brasil sempre esteve direcionada exclusivamente ao emprego da cinza leve como material de construção, não sendo dispensada a mesma atenção à cinza pesada.

Deste modo, é importante que novas investigações sejam desenvolvidas no sentido de procurar novas aplicações para esse resíduo, reduzindo, assim, os impactos ambientais, além de diminuir os custos de disposição em bacias de sedimentação.

\section{4 - OBJETIVO}

O objetivo principal desta dissertação foi investigar, através de ensaios laboratoriais, os efeitos da cinza pesada quando incorporada a solos, visando o aproveitamento deste resíduo na construção de bases e sub-bases de pavimentos. Também foi avaliado o efeito da adição de cal às misturas solocinza.

A verificação da viabilidade do emprego da cinza foi feita por meio de uma avaliação dos efeitos resultantes da incorporação de cinza pesada aos solos coletados na região da Usina Termelétrica Jorge Lacerda à luz das especificações para materiais tipicamente empregados na construção de bases e sub-bases de pavimentos.

O estudo foi desenvolvido com base na análise da resistência à compressão simples, à tração por compressão diametral e ensaios para determinação da capacidade de suporte mini-CBR e CBR de corpos-de-prova 
compactados, compostos de misturas de solo e cinza pesada em vários teores e também de solo-cinza-cal ensaiados em três períodos de cura diferentes.

\section{5 - ORGANIZAÇÃO DO TRABALHO}

Este estudo foi desenvolvido como dissertação de mestrado e dividido em cinco capítulos. O primeiro é a presente introdução e os outros quatro foram divididos da seguinte maneira:

O capítulo 2 apresenta a revisão bibliográfica, abordando aspectos relevantes para o desenvolvimento da pesquisa. Destacam-se neste capítulo o processo de obtenção da cinza, suas características químicas, físicas, mecânicas, mineralógicas e morfológicas, o comportamento, em laboratório, de misturas compactadas contendo este resíduo e seu uso na construção civil.

O capítulo 3 descreve o procedimento para escolha do local de estudo e dos solos, apresenta a caracterização e classificação dos materiais utilizados (solo, cinza pesada e cal) bem como a descrição do método experimental e dos ensaios laboratoriais realizados.

O capítulo 4 apresenta e discute os resultados obtidos a partir dos ensaios laboratoriais, com destaque para a influência do teor de cinza pesada e do tempo de cura na resistência à compressão simples, resistência à tração por compressão diametral e na deformabilidade, além dos efeitos resultantes da adição de cal às misturas com solo e cinza.

No capítulo 5 são apresentadas as conclusões obtidas a partir da análise dos resultados laboratoriais e as recomendações para trabalhos futuros. 


\section{CAPÍTULO 2}

\section{REVISÃO BIBLIOGRÁFICA}

\section{1 - INTRODUÇÃO}

Nas usinas termelétricas, a queima do carvão mineral para a geração de energia elétrica produz dois subprodutos sólidos: a cinza leve e a cinza pesada, ambos nocivos ao meio ambiente (ROCHA et al. 1999; LOVELL et al. 1991). As propriedades destas cinzas dependem de diversos fatores, tais como: qualidade do carvão utilizado, tipo de caldeira e temperatura de queima.

A cinza leve é um material de granulometria fina, não plástico e que apresenta propriedades pozolânicas. Esse subproduto é coletado através do fluxo de gases provenientes da combustão do carvão, nas caldeiras das termelétricas, pelos precipitadores eletrostáticos. A cinza aderida a estes equipamentos é transferida para os silos de estocagem para, então, ser comercializada e empregada na fabricação de cimentos pozolânicos. Além disso, várias pesquisas têm indicado seu uso na engenharia, seja na construção de bases e sub-bases de pavimentos ou na fabricação de argamassas e concretos.

A cinza pesada, por sua vez, é um material granular, poroso, com granulometria predominantemente de areia. Essa cinza, gerada a partir da aglomeração dos grãos semifundidos no interior da câmara de combustão, deposita-se no fundo da caldeira e é transportada por arraste hidráulico até as bacias de sedimentação. 
Nos Estados Unidos e em outros países desenvolvidos, a cinza pesada é usada, principalmente, como material para base e sub-base de pavimentos, como agregado para concretos, asfaltos e argamassas para alvenaria e na construção de diques.

No Brasil, ao contrário do que acontece com a cinza leve, a cinza pesada tem tido pouca utilização, ficando depositada a céu aberto em grandes bacias de sedimentação. As poucas pesquisas desenvolvidas no país visando o emprego mais nobre da cinza pesada estão voltadas para a fabricação de artefatos de cimento e de concreto. Desta maneira, é imprescindível investigar e avaliar novas alternativas de aproveitamento desse material como, por exemplo, na construção de bases e sub-bases de pavimentos.

\section{2 - PROCESSO DE OBTENÇÃO DAS CINZAS LEVE E PESADA}

As cinzas provenientes das usinas termelétricas, que utilizam o carvão mineral como combustível, têm composição sílico-aluminosa e resultam da combustão do carvão pulverizado a altas temperaturas no interior das caldeiras, produzindo o vapor aquecido que atuará na geração de energia elétrica (USMEN et al., 1983).

No interior das caldeiras, a existência de diferentes zonas de temperaturas faz com que as partículas do carvão pulverizado apresentem, após a queima, características diferentes, resultando em frações de cinzas com características físicas, químicas, mineralógicas e microestruturais distintas, sendo possível classificar as cinzas em dois tipos distintos: leves (secas) e pesadas (úmidas) que serão descritas posteriormente neste capítulo. Devido às altas temperaturas, as partículas tendem a tomar a forma arredondada, enquanto exposições limitadas à baixa temperatura provocam um menor grau de arredondamento, sendo que as frações mais finas são ricas em partículas esféricas (NARDI, 1988). 
Nas indústrias de geração de energia, o processo mais comum de queima do carvão mineral é o seco. Quando o carvão pulverizado é queimado a seco, cerca de $80 \%$ do material não queimado ou cinza é conduzido pelos gases da combustão através de dutos até os precipitadores eletrostáticos, que ficam posicionados antes da chaminé de exaustão. Estes precipitadores retêm a chamada cinza leve ou volante que em seguida é armazenada em silos de concreto, prontas para serem comercializadas e empregadas na fabricação do cimento pozolânico (FEDERAL HIGHWAY ADMINISTRATION, 1998). Este tipo de cinza é um resíduo finamente dividido, não plástico, inorgânico, de cor cinza, com partículas esféricas, granulometria uniforme e tamanho dos grãos semelhante ao dos siltes, apresentando atividade pozolânica quando na presença da água (USMEN et al., 1983).

Os outros $20 \%$ do material restante não queimado é a cinza pesada. Este material é caracterizado por ser um resíduo inorgânico relativamente grosso, poroso, de cor cinza escuro e com granulometria predominantemente de areia, que cai por gravidade, através da caldeira, dentro de um tanque. Quando uma quantidade suficiente de cinza cai nesse tanque, a cinza pesada é removida por meio de arraste hidráulico para as bacias de sedimentação, nas quais fica estocada (FEDERAL HIGHWAY ADMINISTRATION, 1998). A figura 2.1 ilustra o processo de geração de energia térmica por meio da queima do carvão mineral pulverizado a seco em uma termelétrica tipicamente encontrada no Brasil. Desse processo resultam as cinzas leves e pesadas.

Outro tipo de processo de obtenção da cinza pesada é o úmido e, nesse caso, a cinza é conhecida como "boiler slag" (escória de caldeira). Existem dois tipos de caldeiras que podem ser empregadas neste processo: a caldeira tipo ciclone e a caldeira tipo "slag-tap". O primeiro tipo queima o carvão triturado, enquanto que o segundo queima o carvão pulverizado. Em ambos os tipos, a cinza é mantida em um estado fundido e é extraída como um líquido. Esses dois tipos de caldeira têm uma base sólida com um orifício que é aberto para permitir que a cinza no estado fundido caia em um tanque, onde é resfriada por meio de jatos d'água. 
Quando a cinza pesada, no estado fundido, entra em contato com a água de resfriamento há um fraturamento imediato, ocorrendo cristalização e formação de "pelotas". A escória resultante é um material grosso, duro, negro, angular e vítreo.

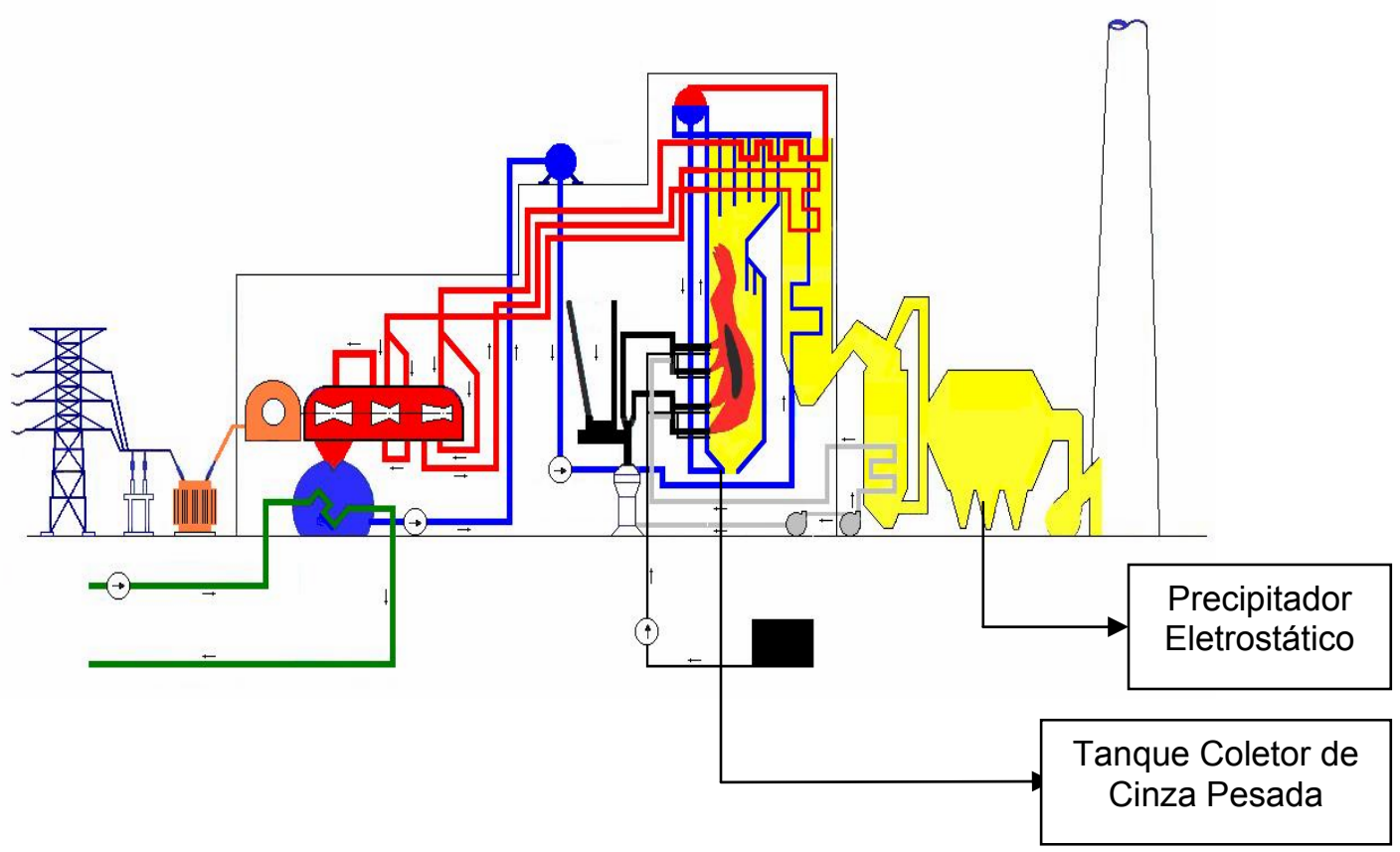

FIGURA 2.1 - Esquema de geração de energia térmica e produção das cinzas (TRACTEBEL ENERGIA, 2002).

Nos Estados Unidos, é produzido ainda outro tipo de cinza. Essa cinza é derivada de uma tecnologia que permite controlar a emissão de dióxido de enxofre na atmosfera. Isso se deve ao fato de que o combustível mineral é queimado numa caldeira denominada AFBC (Atmospheric Fluidized Bed Combustion). Uma desvantagem desse tipo de caldeira é que são produzidas grandes quantidades de resíduos sólidos. Para cada tonelada de carvão queimado em uma caldeira AFBC são adicionados de $1 / 3$ a $1 / 5$ de pedra calcária para reduzir as emissões de enxofre, resultando em um aumento de 3 a 4 vezes a geração de resíduos sólidos, se comparado às caldeiras de queima pulverizada de carvão a seco (DESCHAMPS, 1997). Esse aumento deve provocar, então, uma saturação mais acelerada das lagoas de disposição de cinzas, exigindo, assim, a construção de novos locais para depósito. 
Nos Estados Unidos, segundo Pandeline et al. (1997), as cinzas pesadas também podem ser geradas através da incineração de lixo, por meio do processo denominado de Combustão de Resíduos Sólidos Municipais (MWC). Esse processo tem a finalidade de reduzir os volumes de lixo depositados nos aterros sanitários, através da queima dos resíduos em dois tipos de instalações de incineração: "Mass- Burn" (MB) e "Refuse-Derived-Fuel" (RDF). A redução no volume de lixo é da ordem de $90 \%$, contudo ainda restam $10 \%$ de resíduos não combustíveis (cinzas), resultantes do processo de queima, que são depositados nas lagoas de sedimentação.

No processo de incineração de lixo através das instalações RDF, os resíduos são despejados num espaço pavimentado, onde itens processáveis e não-processáveis são separados. A correia transportadora transfere o material propício ao beneficiamento (queima) para os alimentadores, que abastecem os trituradores, que trituram o lixo a um tamanho adequado. Em seguida, o lixo triturado é submetido ao processo responsável pela remoção de metais e alumínios que são encaminhados a reciclagem. O restante do material é estocado e usado como combustível na geração de energia por meio da incineração em caldeiras. Deste modo, a queima dos resíduos origina a cinza pesada, que precipita em um tanque com água e, então, é misturada com a cinza leve para depois ser depositada, também, nas bacias de sedimentação.

O processo de queima MB é idêntico ao anterior, contudo, neste processo o material é classificado em metálico e não metálico depois da combustão. A cinza que cai através da caldeira é resfriada em água e combinada com a cinza leve, coletada por meio de precipitadores. Essa mistura de cinzas é então levada a um separador de materiais ferrosos e não-ferrosos para permitir a posterior reciclagem. Os materiais ferrosos são extraídos por eletroímãs, enquanto que os não-ferrosos são classificados por tamanho e peso. O material restante (cinzas) é depositado em bacias de sedimentação. 


\section{3 - CINZA PESADA}

Serão apresentados a seguir vários estudos desenvolvidos por alguns autores referentes às características químicas, físicas e mecânicas das cinzas pesadas, principalmente das derivadas da queima do carvão pulverizado a seco em usinas termelétricas.

\subsection{1 - Características Químicas}

A cinza pesada é composta principalmente por sílica, alumina e óxido de ferro, com porcentagens menores de cálcio, magnésio, sulfatos e outras combinações. A composição química desse tipo de material depende principalmente da fonte de carvão mineral. Cinzas derivadas de linhitas ou carvões sub-betuminosos têm uma porcentagem maior de cálcio do que as cinzas derivadas de antracito ou carvão betuminoso (FEDERAL HIGHWAY ADMINISTRATION, 1998). A tabela 2.1 apresenta os resultados das análises químicas de amostras de cinza pesada de diferentes tipos de carvão e diferentes regiões dos Estados Unidos.

TABELA 2.1 - Composição química de cinzas pesadas americanas (FEDERAL HIGHWAY ADMINISTRATION, 1998).

\begin{tabular}{|c|c|c|c|c|c|c|}
\hline \multirow{2}{*}{\multicolumn{2}{|c|}{$\frac{\text { Localização }}{\text { Tipo do Carvão }}$}} & \multicolumn{2}{|c|}{ West Virginia } & Ohio & \multicolumn{2}{|c|}{ Texas } \\
\hline & & & tumin & & Sub-betuminoso & Linhita \\
\hline \multirow{7}{*}{ 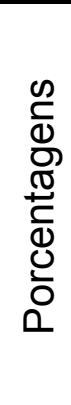 } & $\mathrm{SiO}_{2}$ & 53,6 & 45,9 & 47,1 & 45,4 & 70 \\
\hline & $\mathrm{Al}_{2} \mathrm{O}_{3}$ & 28,3 & 25,1 & 28,3 & 19,3 & 15,9 \\
\hline & $\mathrm{Fe}_{2} \mathrm{O}_{3}$ & 5,8 & 14,3 & 10,7 & 9,7 & 2,0 \\
\hline & $\mathrm{CaO}$ & 0,4 & 1,4 & 0,4 & 15,3 & 6,0 \\
\hline & $\mathrm{MgO}$ & 4,2 & 5,2 & 5,2 & 3,1 & 1,9 \\
\hline & $\mathrm{Na}_{2} \mathrm{O}$ & 1,0 & 0,7 & 0,8 & 1,0 & 0,6 \\
\hline & $\mathrm{K}_{2} \mathrm{O}$ & 0,3 & 0,2 & 0,2 & - & 0,1 \\
\hline
\end{tabular}

Lovell et al. (1991), também realizaram as análises químicas de várias amostras de cinzas pesadas provenientes de diferentes usinas do estado de Indiana, Estados Unidos, através do método de absorção atômica espectrofotométrica. Além de determinar a porcentagem de cada elemento 
presente na composição das cinzas, os pesquisadores também verificaram a perda ao fogo, com objetivo de obter uma indicação do teor de carbono não queimado. A tabela 2.2 apresenta a composição química de cinzas pesadas provenientes de diferentes usinas americanas e da Usina Jorge Lacerda, localizada no estado de Santa Catarina.

As propriedades químicas das cinzas pesadas são muito específicas quando comparadas às dos agregados convencionais. A variabilidade nos teores de óxido de ferro e alumínio na maior parte das cinzas pesadas, para uma mesma usina, é relativamente pequena se o carvão e outras condições de combustão são mantidas, como pode ser visto na tabela 2.2. Através desta tabela, é possível verificar que nas usinas onde as condições de queima foram mantidas parecidas, no primeiro e no segundo dia de coleta, as porcentagens de óxido de ferro e alumínio na composição química de cada cinza mostraram um razoável grau de uniformidade, com exceção da cinza da usina de "Mitchell", onde ocorreu uma variação significativa na porcentagem de óxido de alumínio. Já nas usinas onde a condição de queima não foi mantida constante, os pesquisadores observaram uma considerável variação na quantidade de óxido de ferro e de alumínio. Na cinza pesada proveniente da usina de "Stout", além de verificadas variações significativas nos teores de óxido de ferro e óxido de alumínio, essa cinza também apresentou uma diferença razoável na quantidade de $\mathrm{SiO}_{2}$.

No Brasil, Nardi (1988) e Rocha et al. (1999) caracterizaram quimicamente a cinza pesada proveniente da Usina Termelétrica Jorge Lacerda. Os resultados obtidos revelaram que esta cinza também é essencialmente constituída por uma composição sílico-aluminosa (ROCHA, 1999) ou sílico-ferrosa-aluminosa (NARDI, 1988), sendo que o somatório dos teores de $\mathrm{SiO}_{2}, \mathrm{Al}_{2} \mathrm{O}_{3}$ e $\mathrm{Fe}_{2} \mathrm{O}_{3}$ correspondem, praticamente, a totalidade em peso dos componentes óxidos em sua composição química. Outros elementos, como $\mathrm{TiO}_{2}, \mathrm{MnO}$ e $\mathrm{P}_{2} \mathrm{O}_{5}$, aparecem em uma quantidade mínima, totalizando apenas 1,19\% em peso na análise feita por Nardi (1988) e 1,59\% na análise feita por Rocha et al. (1999). 
TABELA 2.2 - Composição química de cinzas pesadas provenientes de diferentes usinas do estado de Indiana (LOVELL et al., 1991) e da cinza pesada da Usina Jorge Lacerda, Santa Catarina (NARDI, 1988 e ROCHA, 1999).

\begin{tabular}{|c|c|c|c|c|c|c|c|c|c|c|}
\hline \multirow[b]{2}{*}{ Usina } & \multirow[b]{2}{*}{$\begin{array}{l}\text { Data de } \\
\text { coleta }\end{array}$} & \multicolumn{9}{|c|}{ Porcentagens } \\
\hline & & $\mathrm{SiO}_{2}$ & $\mathrm{Fe}_{2} \mathrm{O}_{3}$ & $\mathrm{Al}_{2} \mathrm{O}_{3}$ & $\mathrm{CaO}$ & $\mathrm{MgO}$ & $\mathrm{K}_{2} \mathrm{O}$ & $\mathrm{Na}_{2} \mathrm{O}$ & $\mathrm{SO}_{3}$ & $\begin{array}{c}\text { Perda } \\
\text { ao } \\
\text { fogo }\end{array}$ \\
\hline \multirow{2}{*}{$\begin{array}{c}\text { Schahfer } \\
\text { Unidade } 14\end{array}$} & 19/06/87 & 60.1 & 5.2 & 10.4 & 16.6 & 5.7 & 0.9 & 0.4 & 0.9 & 0.3 \\
\hline & $12 / 05 / 88$ & 53.4 & 6.0 & 13.5 & 18.5 & 5.7 & 1.2 & 0.3 & 1.0 & 0.1 \\
\hline \multirow{2}{*}{$\begin{array}{l}\text { Schahfer } \\
\text { Unidade } 17\end{array}$} & 19/06/87 & 58.1 & 15.2 & 12.7 & 7.0 & 0.8 & 1.9 & 0.3 & 2.2 & 0.1 \\
\hline & $12 / 05 / 88$ & 52.1 & 23.2 & 13.2 & 4.8 & 0.9 & 1.4 & 0.2 & 1.5 & 0.8 \\
\hline \multirow{2}{*}{ Gibson } & $18 / 05 / 87$ & 58.7 & 14.6 & 14.1 & 3.1 & 0.8 & 2.0 & 0.4 & 1.3 & 0.4 \\
\hline & $17 / 05 / 88$ & 53.6 & 20.8 & 14.8 & 2.6 & 1.0 & 1.9 & 0.5 & 1.1 & 1.0 \\
\hline \multirow{2}{*}{ Gallagher } & $26 / 05 / 87$ & 41.2 & 28.4 & 11.2 & 12.6 & 0.7 & 1.6 & 0.3 & 1.0 & 0.9 \\
\hline & $14 / 05 / 88$ & 49.3 & 24.2 & 16.4 & 3.9 & 0.9 & 1.7 & 0.2 & 2.6 & 1.4 \\
\hline \multirow{2}{*}{ Perry $^{(a)}$} & 19/05/87 & 48.0 & 22.2 & 13.0 & 0.8 & 0.7 & 2.2 & 0.3 & 0.6 & 7.2 \\
\hline & $14 / 05 / 88$ & 52.5 & 6.0 & 24.3 & 0.9 & 0.1 & 2.3 & 0.4 & 0.6 & 6.2 \\
\hline \multirow{2}{*}{ Mitchell } & 19/06/87 & 58.8 & 6.8 & 7.8 & 7.9 & 2.2 & 1.4 & 0.1 & 3.3 & 8.1 \\
\hline & $12 / 05 / 88$ & 51.3 & 6.5 & 14.2 & 8.5 & 3.0 & 0.9 & 0.3 & 1.0 & 8.0 \\
\hline \multirow{2}{*}{ Wabash } & $23 / 06 / 87$ & 55.7 & 21.5 & 14.3 & 1.7 & 0.7 & 1.9 & 0.3 & 0.8 & 0.2 \\
\hline & $26 / 04 / 88$ & 51.7 & 23.0 & 16.0 & 1.7 & 0.9 & 1.9 & 0.3 & 0.6 & 1.0 \\
\hline \multirow{2}{*}{ Richmond $^{(a)}$} & $17 / 08 / 87$ & 48.3 & 33.3 & 11.9 & 1.3 & 0.4 & 0.9 & 0.2 & 1.7 & 2.2 \\
\hline & $05 / 05 / 88$ & 41.6 & 20.9 & 18.6 & 1.3 & 0.6 & 1.1 & 0.1 & 1.9 & 14.1 \\
\hline \multirow{2}{*}{ Stout $^{(a)}$} & $27 / 05 / 87$ & 24.2 & 42.0 & 6.9 & 2.2 & 0.4 & 0.6 & 0.2 & 0.8 & 18.4 \\
\hline & $20 / 06 / 88$ & 54.9 & 20.2 & 16.7 & 1.6 & 0.9 & 1.9 & 0.8 & 1.8 & 0.3 \\
\hline \multirow{2}{*}{ Culley } & $21 / 08 / 87$ & 35.6 & 30.1 & 11.7 & 14.6 & 0.8 & 1.4 & 0.3 & 1.0 & 0.0 \\
\hline & $14 / 05 / 88$ & 31.0 & 31.1 & 11.8 & 13.9 & 1.1 & 0.5 & 0.2 & 0.9 & 0.3 \\
\hline \multirow{2}{*}{ Brown } & $21 / 08 / 87$ & 48.1 & 27.6 & 13.4 & 3.1 & 0.8 & 2.1 & 0.3 & 1.7 & 1.9 \\
\hline & $17 / 05 / 88$ & 38.5 & 38.0 & 12.6 & 3.8 & 0.7 & 1.3 & 0.2 & 3.3 & 1.1 \\
\hline Média & & 48.6 & 21.2 & 13.6 & 6.0 & 1.4 & 1.5 & 0.3 & 1.4 & 3.4 \\
\hline BRASIL $^{(b)}$ & & 41,3 & 30,3 & 18,9 & 1,4 & 0,6 & 1,8 & 0,24 & - & 4,0 \\
\hline$\pi$ & & $0 b, 9 c$ & 5,80 & 6,1 & J, ৪< &,, 5 & 2,59 & 25 & & 4,61 \\
\hline
\end{tabular}

\footnotetext{
(a) Usinas que queimaram carvões diferentes da primeira para a segunda amostragem.

(b) Usina Termelétrica Jorge Lacerda (NARDI, 1988).

(c) Usina Termelétrica Jorge Lacerda (ROCHA et al., 1999).
}

As interações entre o uso da cinza pesada e estruturas de concreto e aço são pouco conhecidas, uma vez que as características eletroquímicas das cinzas pesadas não são bem definidas. Assim, Ke e Lovell (1992) avaliaram o potencial corrosivo das cinzas pesadas do estado americano de Indiana com o objetivo de verificar a extensão deste problema. 
Pesquisas referentes ao estudo da corrosão em metais provocada pela cinza pesada são escassos. Assim, Ke (1990) fez uso do conhecimento do mecanismo de corrosão de metais em contato com solos para estudar a corrosão devido à presença da cinza pesada.

Ke (1990), considerando a natureza das cinzas pesadas e as condições do local depois da construção, concluiu que os parâmetros que melhor se relacionam com a corrosividade das cinzas são: resistividade, $\mathrm{pH}$, teor de cloreto solúvel e sulfato solúvel. Segundo Ke (1990), um material com valores menores de resistividade e $\mathrm{pH}$ e valores maiores de cloreto solúvel e sulfato solúvel é, geralmente, mais corrosivo.

Os limites para se estabelecer o potencial não corrosivo das cinzas pesadas são baseados nos critérios disponíveis de corrosividade em solos: uma resistividade mínima de 1500ohm-cm, um pH mínimo de 5,5, um máximo de 200ppm de cloreto solúvel e um máximo de 1000ppm de sulfato solúvel. Caso qualquer um desses parâmetros citados não seja alcançado, a cinza será classificada como corrosiva.

Desta forma, das onze usinas do estado de Indiana pesquisadas por Ke e Lovell (1992), sete apresentaram cinzas classificadas como corrosivas, o que sugere que cuidados especiais devem ser tomados quando se fizer uso deste tipo de resíduo junto a estruturas metálicas. A tabela 2.3 apresenta os valores referentes aos parâmetros de corrosividade das cinzas pesadas estudadas por Ke e Lovell (1992). 
TABELA 2.3 - Corrosividade das cinzas pesadas do estado americano de Indiana (KE e LOVELL et al., 1992).

\begin{tabular}{|c|c|c|c|c|c|}
\hline $\begin{array}{c}\text { Procedência } \\
\text { da Cinza } \\
\text { Pesada }\end{array}$ & $\begin{array}{c}\text { Resistividade } \\
(\mathrm{r})\end{array}$ & $\mathrm{pH}$ & $\begin{array}{c}\text { Cloreto } \\
\text { Solúvel } \\
\left(\mathrm{Cl}^{-}\right)\end{array}$ & $\begin{array}{c}\text { Sulfato Solúvel } \\
\left(\mathrm{SO}^{-2}{ }_{4}\right)\end{array}$ & \multirow{2}{*}{ Corrosiv. } \\
\cline { 2 - 5 } & $\begin{array}{c}\mathrm{r}>1500 \\
\mathrm{ohm}-\mathrm{cm}\end{array}$ & $\mathrm{pH}>5,5$ & $\begin{array}{c}\mathrm{Cl}^{-}<200 \\
\mathrm{ppm}\end{array}$ & $\mathrm{SO}^{-2}{ }_{4}<1000$ & \\
\hline Perry & 980 & 4,8 & 15,5 & 598 & $\mathrm{C}$ \\
\hline Gibson & 2201 & 7,6 & 7,3 & 1127 & $\mathrm{C}$ \\
\hline Schahfer 14 & $>6663$ & 9,6 & 0,4 & 50 & $\mathrm{NC}$ \\
\hline Schahfer 17 & 3082 & 8,6 & 6,1 & 383 & $\mathrm{NC}$ \\
\hline Gallegher & 335 & 9,1 & - & - & $\mathrm{C}$ \\
\hline Mitchell & 1771 & 8,0 & - & - & $\mathrm{NC}$ \\
\hline Wabash & 1051 & 5,7 & - & - & $\mathrm{C}$ \\
\hline Richmond & 247 & 8,2 & - & - & $\mathrm{NC}$ \\
\hline Stout & 4249 & 6,6 & - & - & $\mathrm{C}$ \\
\hline Culley & 486 & 8,5 & - & - & $\mathrm{C}$ \\
\hline Brown & 213 & 3,2 & - & - & \\
\hline
\end{tabular}

C - Corrosiva

NC - Não Corrosiva

\subsection{2 - A Cinza Pesada e o Meio Ambiente}

Para analisar a periculosidade do uso de cinzas pesadas ao meio ambiente, sobretudo sobre a qualidade da água e a contaminação do solo, Lovell et al. (1991) e Deschamps (1997) realizaram testes de lixiviação nas cinzas pesadas provenientes da queima do carvão pelo método tradicional e pelo método AFBC, respectivamente.

O método proposto pela Environmental Protection Agency (EPA), conhecido como procedimento de Extração Toxicológica (EP), foi utilizado em ambas as pesquisas para averiguar o potencial contaminante das cinzas. Este procedimento procura simular a lixiviação de um resíduo sólido em um aterro sanitário.

As concentrações de metais pesados, obtidas nessas duas pesquisas citadas, ficaram bem abaixo do nível máximo de contaminação (MCL) especificado pela EPA. Deste modo, ambas as pesquisas concluíram que as cinzas pesadas podem ser classificadas como um material sem periculosidade 
ao meio ambiente. Entretanto, Lovell et al. (1991) encontraram um teor de Cádmio maior do que o permitido para a água potável (tabela 2.4).

TABELA 2.4 - Análise toxicológica das cinzas pesadas (LOVELL et al., 1991; DESCHAMPS, 1997).

\begin{tabular}{|c|c|c|c|c|c|c|c|c|}
\hline Procedência & \multicolumn{7}{|c|}{ Contaminante (mg/L) } \\
\cline { 2 - 9 } & Mercúrio & Prata & Cádmio & Cromo & Arsênio & Selênio & Bário & Chumbo \\
\hline $\begin{array}{c}\text { Schahfer } \\
\text { Unid. 17 }\end{array}$ & 0,0002 & 0,001 & 0,0008 & 0,0009 & 0,020 & 0,005 & 0,098 & 0,007 \\
\hline Gibson & 0,0001 & $<0,001$ & 0,025 & 0,0005 & 0,010 & 0,005 & 0,103 & 0,002 \\
\hline $\begin{array}{c}\text { Schahfer } \\
\text { Unid. 14 }\end{array}$ & $<0,0001$ & $<0,001$ & 0,0007 & 0,0012 & 0,005 & 0,003 & 0,136 & $<0,001$ \\
\hline $\begin{array}{c}\text { Perry } \\
\text { (b) }\end{array}$ & 0,0002 & $<0,001$ & 0,0004 & 0,0009 & 0,008 & 0,004 & 0,108 & 0,005 \\
\hline $\begin{array}{c}\text { Purdue Bag } \\
\text { House }{ }^{(a)}\end{array}$ & - & - & - & 0,03 & - & 0,002 & 0,07 & - \\
\hline $\begin{array}{c}\text { Purdue } \\
\text { Heat } \\
\text { Recovery }\end{array}$ & - & - & - & 0,03 & 0,01 & $<0,008$ & - & - \\
\hline $\begin{array}{c}\text { Purdue } \\
\text { Spend } \\
\text { Bed }\end{array}$ & - & - & - & 0,04 & 0,01 & 0,002 & - & - \\
\hline $\begin{array}{c}\text { Teor } \\
\text { Máximo } \\
\text { Permitido } \\
\text { (EPA) }\end{array}$ & $<0,2$ & $<5,0$ & $<1,0$ & $<5,0$ & $<5,0$ & $<1,0$ & $<100$ & $<5,0$ \\
\hline $\begin{array}{c}\text { Padrão para } \\
\text { Água } \\
\text { Potável }\end{array}$ & $<0,002$ & $<0,05$ & $<0,01$ & $<0,05$ & $<0,05$ & $<0,01$ & $<1,0$ & $<0,05$ \\
\hline $\begin{array}{c}\text { (a) Deschamps (1997) } \\
\text { (b) Lovell et al. (1991) }\end{array}$ & & & & & & & \\
\hline
\end{tabular}

O efeito das cinzas pesadas sobre a qualidade da água subterrânea também foi avaliado nas duas pesquisas pelo teor de sais lixiviados, através do método de ensaio de lixiviação do estado de Indiana. Este ensaio é realizado da mesma forma que o processo EP, porém sem adição de ácido acético.

A tabela 2.5 apresenta os resultados dos ensaios de lixiviação, realizados através do método proposto pelo estado de Indiana e executados por Lovell et al. (1991) e Deschamps (1997). Os primeiros concluíram, através dos resultados obtidos, que as concentrações de sais das cinzas pesadas provenientes da queima do carvão pulverizado estão dentro dos padrões estabelecidos. Contudo, as cinzas estudadas por Deschamps (1997), derivadas 
do processo de queima AFBC, apresentaram concentrações elevadas de sulfato e sulfeto, além de quantidades muito altas de sólidos dissolvidos e elevados valores de $\mathrm{pH}$.

TABELA 2.5 - Ensaios de Lixiviação das Cinzas Pesadas (LOVELL et al., 1991; DESCHAMPS, 1997).

\begin{tabular}{|c|c|c|c|c|c|c|c|c|c|}
\hline \multirow[b]{3}{*}{ Elemento } & \multicolumn{9}{|c|}{ Concentrações (mg/L) } \\
\hline & \multicolumn{3}{|c|}{ LOVELL et al. (1991) } & \multicolumn{4}{|c|}{ DESCHAMPS (1997) } & \multirow[b]{2}{*}{$\begin{array}{c}\text { Conc. } \\
\text { Máxima } \\
\text { (Indiana) }\end{array}$} & \multirow[b]{2}{*}{$\begin{array}{c}\text { Padrão } \\
\text { para } \\
\text { Água } \\
\text { Potável }\end{array}$} \\
\hline & 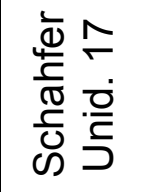 & 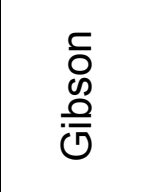 & 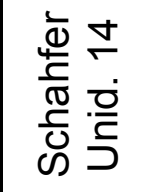 & 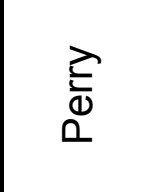 & 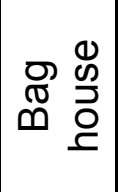 & 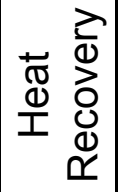 & 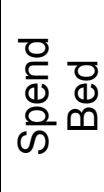 & & \\
\hline Bário & 0,098 & 0,103 & & & 0,38 & 0,37 & 0,18 & 1,0 & 1,0 \\
\hline Boro & 0,21 & 0,19 & & & 0,25 & 0,20 & 0,74 & 2,0 & - \\
\hline Cobre & $<0,1$ & $<0,1$ & $<0,1$ & 0,1 & 0,03 & 0,02 & 0,01 & 0,25 & 1,0 \\
\hline Cloreto & $<1,0$ & $<1,0$ & $<1,0$ & 1,0 & & & & 250 & 250,0 \\
\hline Cianeto & $<0,005$ & $<0,005$ & $<0,005$ & $<0,005$ & - & - & - & 0,20 & - \\
\hline Fluoreto & $<0,1$ & $<0,1$ & $<0,1$ & $<0,1$ & 1,0 & 1,6 & 0,39 & 1,40 & $\begin{array}{c}1,4 a \\
2,4\end{array}$ \\
\hline Ferro & 0,1 & 0,4 & 0,1 & 0,1 & 0,02 & 0,02 & 0,01 & 1,50 & 0,3 \\
\hline Sódio & 0,8 & 1,0 & $<0,5$ & 1,5 & 1,04 & 0,69 & 0,64 & 250,0 & - \\
\hline Sulfato & 31,0 & 55,0 & 19,0 & 26,0 & 1600 & 1800 & 1600 & 250,0 & 250,0 \\
\hline Sulfeto & $<0,1$ & $<0,1$ & $<0,1$ & $<0,1$ & 32,0 & 29,0 & 11,0 & 1,0 & - \\
\hline Zinco & 0,1 & 0,3 & $<0,1$ & $<0,1$ & 0,46 & 0,67 & 0,52 & 2,50 & 5,0 \\
\hline \multicolumn{10}{|l|}{$\begin{array}{c}\text { Total } \\
\text { Dissolvido }\end{array}$} \\
\hline Sólidos & 90,0 & 140,0 & 10,0 & 145,0 & 4700 & 4600 & 4700 & 500,0 & 500,0 \\
\hline Cálcio & 19,0 & 24,0 & 2,0 & 30,0 & - & - & - & - & - \\
\hline Magnésio & 0,7 & 2,0 & 0,2 & 0,1 & - & - & - & - & - \\
\hline Potássio & 1,0 & 0,7 & 0,1 & 2,0 & - & - & - & - & - \\
\hline $\mathrm{pH}$ & 8,9 & 8,4 & 7,8 & 7,7 & 12,6 & 12,6 & 12,5 & 6 a 9 & $\begin{array}{c}6,5 a \\
8,5\end{array}$ \\
\hline
\end{tabular}

\subsection{3 - Características Físicas}

Segundo o FHWA (1998), as cinzas apresentam partículas com textura superficial muito porosa. O tamanho destas partículas varia de um pedregulho a uma areia, com baixa porcentagem de finos. A maior parte dos grãos de cinza pesada apresenta tamanho característico de areia, normalmente com 50 a $90 \%$ passando na peneira $4,75 \mathrm{~mm}\left(\mathrm{~N}^{\circ} 4\right), 10$ a $60 \%$ passando na peneira de malha $0,42 \mathrm{~mm}\left(\mathrm{~N}^{\circ} 40\right), 0$ a $10 \%$ passando na peneira $0,075 \mathrm{~mm}\left(\mathrm{~N}^{\circ} 200\right)$, 
podendo apresentar, ainda, diâmetros máximos na faixa entre $19 \mathrm{~mm}$ e $38,1 \mathrm{~mm}$.

Ainda segundo o FHWA (1998), a cinza pesada é normalmente um material bem graduado, embora possam ser encontradas variações na distribuição granulométrica em amostras coletadas em uma mesma usina, mas em épocas diferentes. A tabela 2.6 mostra a granulometria típica de três amostras de cinzas pesadas provenientes de usinas diferentes do estado americano de West Virginia.

TABELA 2.6 - Distribuição granulométrica típica das cinzas pesadas de três usinas térmicas de West Virginia (FEDERAL HIGHWAY ADMINISTRATION, 1998).

\begin{tabular}{|c|c|c|c|c|}
\hline \multicolumn{2}{|c|}{ Peneira } & \multicolumn{3}{c|}{ Porcentagem Passante } \\
\hline $\mathrm{N}^{\circ}$ & Abertura $(\mathrm{mm})$ & Glasgow & New Haven & Moundsville \\
\hline & 38 & 100 & 99 & 100 \\
\hline & 19 & 100 & 95 & 100 \\
\hline & 9,5 & 100 & 87 & 73 \\
\hline 4 & 4,75 & 90 & 77 & 52 \\
\hline 8 & 2,36 & 80 & 57 & 32 \\
\hline 16 & 1,18 & 72 & 42 & 17 \\
\hline 30 & 0,60 & 65 & 29 & 10 \\
\hline 50 & 0,30 & 56 & 19 & 5 \\
\hline 100 & 0,15 & 35 & 15 & 2 \\
\hline 200 & 0,075 & 9 & 4 & 1 \\
\hline
\end{tabular}

Lovell et al. (1991) coletaram amostras de cinza pesada provenientes de diferentes bacias de sedimentação de usinas termelétricas do estado americano de Indiana. Duas amostras de cada uma das 11 usinas foram coletadas, porém cada uma das coletas foi realizada em um dia diferente.

A análise granulométrica realizada seguiu o método proposto pela AASHTO T27, que indicou que as cinzas pesadas exibem uma distribuição granulométrica bem graduada, sendo que a porcentagem passante na peneira $0,075 \mathrm{~mm}\left(\mathrm{~N}^{\circ} 200\right)$ variou de 0 a $14 \%$ e todas as amostras eram não-plásticas. A figura 2.2 mostra a faixa granulométrica obtida para as 11 cinzas pesadas estudadas por Lovell et al. (1991), área cinza da figura, e as curvas granulométricas das cinzas pesadas da usina Jorge Lacerda, estudadas por 
Rocha (2001) e por Leandro (2002). Através desta figura, é possível verificar que a distribuição granulométrica das cinzas pesadas estudadas por Rocha (2001) e Leandro (2002) não se enquadram na faixa granulométrica determinada por Lovell et al. (1991). Isto se deve, provavelmente, às diferentes características dos carvões empregados no processo de queima.

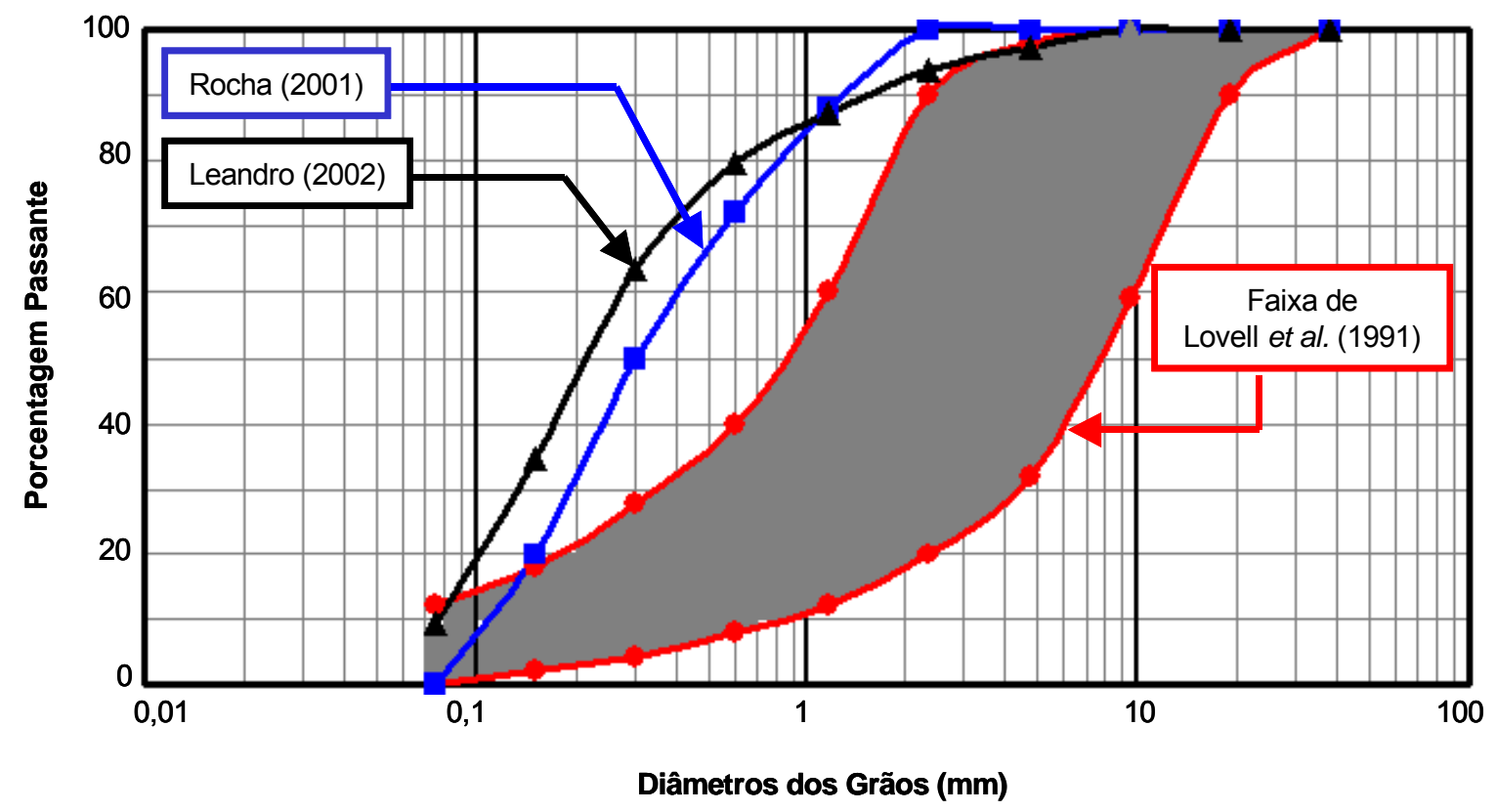

FIGURA 2.2 - Faixa granulométrica das cinzas pesadas estudadas por Lovell et al. (1991) e distribuições granulométricas das cinzas pesadas da Usina Termelétrica Jorge Lacerda (ROCHA, 2001; LEANDRO, 2002).

Das onze cinzas pesadas estudadas por Lovell et al. (1991), dez foram classificadas pelo Sistema Unificado como areias e uma delas como pedregulho. A classificação pelo sistema da AASHTO mostrou que todas as amostras caíram no grupo A-1, sendo que sete amostras foram classificadas como A-1-a e o restante como A-1-b.

Para analisar a variação granulométrica das cinzas provenientes de uma mesma usina, Lovell et al. (1991) coletaram duas amostras de cinzas, porém em dias diferentes. A figura 2.3 mostra a variação na distribuição granulométrica destas cinzas.

Observando a figura 2.3, percebe-se que o deslocamento das curvas granulométricas entre amostras de uma mesma usina foi relativamente 
pequeno. A maior variação granulométrica, com relação a porcentagem passante na peneira $\mathrm{n}^{\circ} 2(9,5 \mathrm{~mm})$, ocorreu para a usina de "Gibson". A diferença entre as quantidades passantes na peneira $n^{\circ} 2$ da amostra 1 e da amostra 2 daquela usina foi de aproximadamente $12 \%$.

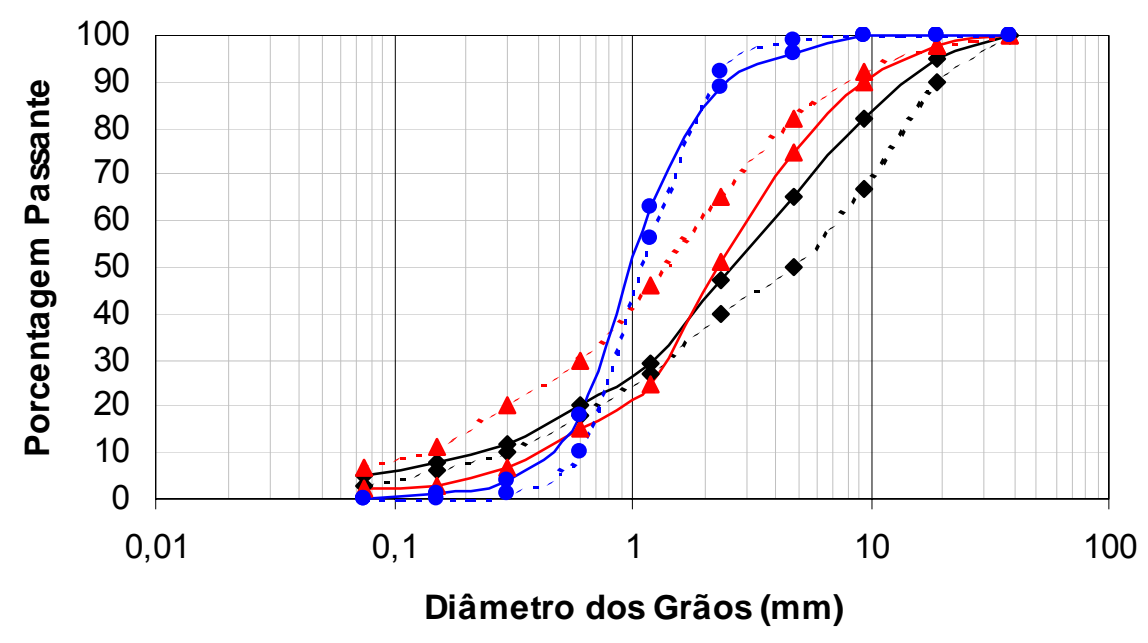

... . . Culley Amostra 2

$\longrightarrow$ Culley Amostra 1

$\longrightarrow$ Gibson Amostra 1

- - - - Gibson Amostra 2

... •. . Schahfer Unid. 14 Amostra $2 \_$Schahfer Unid. 14 Amostra 1

FIGURA 2.3 - Variação das curvas granulométricas de três cinzas pesadas coletadas em diferentes épocas (LOVELL et al., 1991).

Cinzas pesadas com baixa massa específica sempre têm uma textura muito porosa ou vesicular, contribuindo para a degradação das partículas quando submetidas a carregamentos ou compactação, uma vez que a textura porosa está relacionada com a resistência mecânica do material. Deste modo, a massa específica da cinza pode ser usada como um indicativo da sua qualidade (LOVELL et al., 1991).

A massa específica dos sólidos foi determinada por Ksaibati e Bowen (1999) para as cinzas pesadas de três diferentes usinas termelétricas do estado de Wyoming, Estados Unidos. Os resultados obtidos para esses materiais variaram de 2,12 a $2,34 \mathrm{~g} / \mathrm{cm}^{3}$.

Lovell et al. (1991) determinaram a massa específica dos sólidos de onze cinzas pesadas através da AASHTO T84 para agregados finos e através 
da AASHTO T100 para solos. As massas específicas das cinzas pesquisadas apresentaram valores entre 1,90 e $3,40 \mathrm{~g} / \mathrm{cm}^{3}$, ou seja, uma faixa de valores muito mais ampla do que para solos (entre 2,50 e $2,80 \mathrm{~g} / \mathrm{cm}^{3}$ ). Ainda segundo estes pesquisadores, a massa específica dos sólidos é função da composição química, onde alto teor de carbono resultará em uma baixa massa específica, enquanto que alto teor de ferro produzirá altas massas específicas.

Usmen et al. (1983) e Majizadeh et al. (1979) classificaram a cinza pesada como um material não plástico e obtiveram variações nos valores de massa específica dos sólidos similares, compreendidas entre 2,10 e 2,70 $/ \mathrm{cm}^{3}$, mostrando uma disparidade significativa quando comparadas com os resultados obtidos por Ksaibati e Bowen (1999) e Lovell et al. (1991).

A cinza pesada resultante da incineração de resíduos sólidos, estudada por Pandeline et al. (1997), apresenta uma variação de massa específica dos sólidos de 2,45 a $2,79 \mathrm{~g} / \mathrm{cm}^{3}$. Esses valores são similares aos relatados por Collins (1979), por Zhang et al. (1999), por Huang e Lovell (1990) e por Seals et al. (1972). A tabela 2.7 apresenta um resumo das variações de massa específica dos sólidos.

TABELA 2.7 - Variação de massa específica dos sólidos das cinzas pesadas.

\begin{tabular}{|c|c|c|}
\hline Autor & Origem da Cinza Pesada & $\begin{array}{c}\text { Massa } \\
\text { Específica dos } \\
\text { sólidos (g/cm }{ }^{3} \text { ) }\end{array}$ \\
\hline SEALS et al. (1972) & Queima do carvão mineral & 2,28 a 2,78 \\
\hline MAJIZADEH et al. (1979) & Queima do carvão mineral & 2,10 a 2,70 \\
\hline COLLINS (1979) & Queima do carvão mineral & 2,27 a 2,53 \\
\hline USMEN et al. (1983) & Queima do carvão mineral & 2,10 a 2,70 \\
\hline HUANG e LOVELL (1990) & Queima do carvão mineral & 1,94 a 3,23 \\
\hline LOVELL et al. (1991) & Queima do carvão mineral & 1,90 a 3,40 \\
\hline PANDELINE et al. (1997) & Incineração de resíduos sólidos & 2,45 a 2,79 \\
\hline KSAIBATI e BWEN (1999) & Queima do carvão mineral & 2,12 a 2,34 \\
\hline ZHANG et al. (1999) & Incineração de resíduos sólidos & 1,85 a 2,19 \\
\hline
\end{tabular}


No estudo desenvolvido por Rocha (2001), visando o emprego das cinzas leves e pesadas na produção de concretos de cimento Portland usinados, blocos e pavimentos de concreto, a cinza pesada utilizada apresentava uma massa específica de $1,91 \mathrm{~g} / \mathrm{cm}^{3}$, ou seja, inferior ao citado na bibliografia internacional. Já em outro estudo apresentado em 2002 por Leandro, a cinza pesada oriunda da mesma usina termelétrica estudada por Rocha (2001) apresentou uma massa específica de $1,98 \mathrm{~g} / \mathrm{cm}^{3}$. Uma outra pesquisa desenvolvida por Nardi relatada em 1988 indicou uma massa específica de $2,28 \mathrm{~g} / \mathrm{cm}^{3}$ para a cinza pesada proveniente da mesma usina, ou seja, apresenta um valor bem diferente daqueles obtidos por Rocha em 2001 e Leandro em 2002.

Já Piazza e Rui (1999), analisando o comportamento da cinza pesada na substituição da areia quartzosa em argamassas, encontraram um valor de massa específica de $2,26 \mathrm{~g} / \mathrm{cm}^{3}$ para a cinza pesada da termelétrica de Charqueadas, Rio Grande do Sul, valor semelhante ao apresentado por Nardi (1988) para a termelétrica Jorge Lacerda.

\subsection{4 - Características Mineralógicas e Morfológicas}

Segundo Nardi (1988), do ponto de vista mineralógico, a cinza pesada é formada por uma fase vítrea, de natureza sílico-aluminosa, constituindo a maioria dos grãos de cinza e, secundariamente, por mulita, quartzo, hematita e magnetita, sendo comum a ocorrência de carbono amorfo associado aos grãos.

A fase vítrea é a mais importante e é constituída principalmente por grãos não opacos de forma arredondada. Sua formação está relacionada ao conteúdo de argilo-minerais e às condições de calcinação do carvão. A presença e a freqüência dos esferolitos vítreos é um indicativo de boa qualidade pozolânica. A cinza pesada da termelétrica Jorge Lacerda apresenta grande quantidade de esferolitos vítreos, indicando que esta cinza pode apresentar bom potencial pozolânico (NARDI, 1988). 
Ainda segundo o estudo feito por Nardi (1988), a freqüência de quartzo diminui em função do aumento da temperatura de calcinação e da finura, participando na formação da fase vítrea. Já a magnetita e a hematita formamse a partir da decomposição da pirita. O carbono nas cinzas, por sua vez, apresenta morfologia variada, estando presente na forma de massas irregulares, aglomerados reticulares e esferas. Esse carbono apresenta-se na forma amorfa e a quantidade está relacionada às condições de combustão, umidade e finura do carvão.

Com o objetivo de caracterizar a forma das partículas e a textura superficial da cinza pesada, Lovell et al. (1991) conduziram um exame microscópico nas onze cinzas pesadas. Nele foi verificado que as partículas de cinza eram completamente angulares e apresentavam uma superfície altamente porosa, com uma textura semelhante a de uma "pipoca".

\subsection{5 - Propriedades Mecânicas da Cinza Pesada}

O ensaio de compactação das cinzas pesadas, através do método de Proctor, produz curvas irregulares devido a complexa estrutura porosa das partículas constituintes (USMEM et al., 1983). Essa irregularidade das curvas de compactação também foi verificada por Lovell et al. (1991) e a figura 2.4 mostra um exemplo desse comportamento.

Essas curvas são caracterizadas por apresentarem uma massa específica seca elevada para o ramo mais seco da curva de compactação, baixa massa específica seca para teores de umidade intermediários e, por fim, voltam a apresentar alta massa específica seca para teores de umidade maiores, no ramo úmido da curva de compactação (figura 2.4). Segundo Lovell et al. (1991), este comportamento é típico de materiais sem coesão.

No campo, ainda segundo Lovell et al. (1991), geralmente as curvas de compactação exibem também massa específica seca máxima tanto numa condição mais seca como numa condição mais úmida, com teor de umidade 
próximo da saturação. Contudo, como a compactação da cinza pesada, no campo, num estado seco não é possível, é recomendado que ela seja mantida num teor de umidade alto, com o objetivo de se alcançar uma maior densificação.

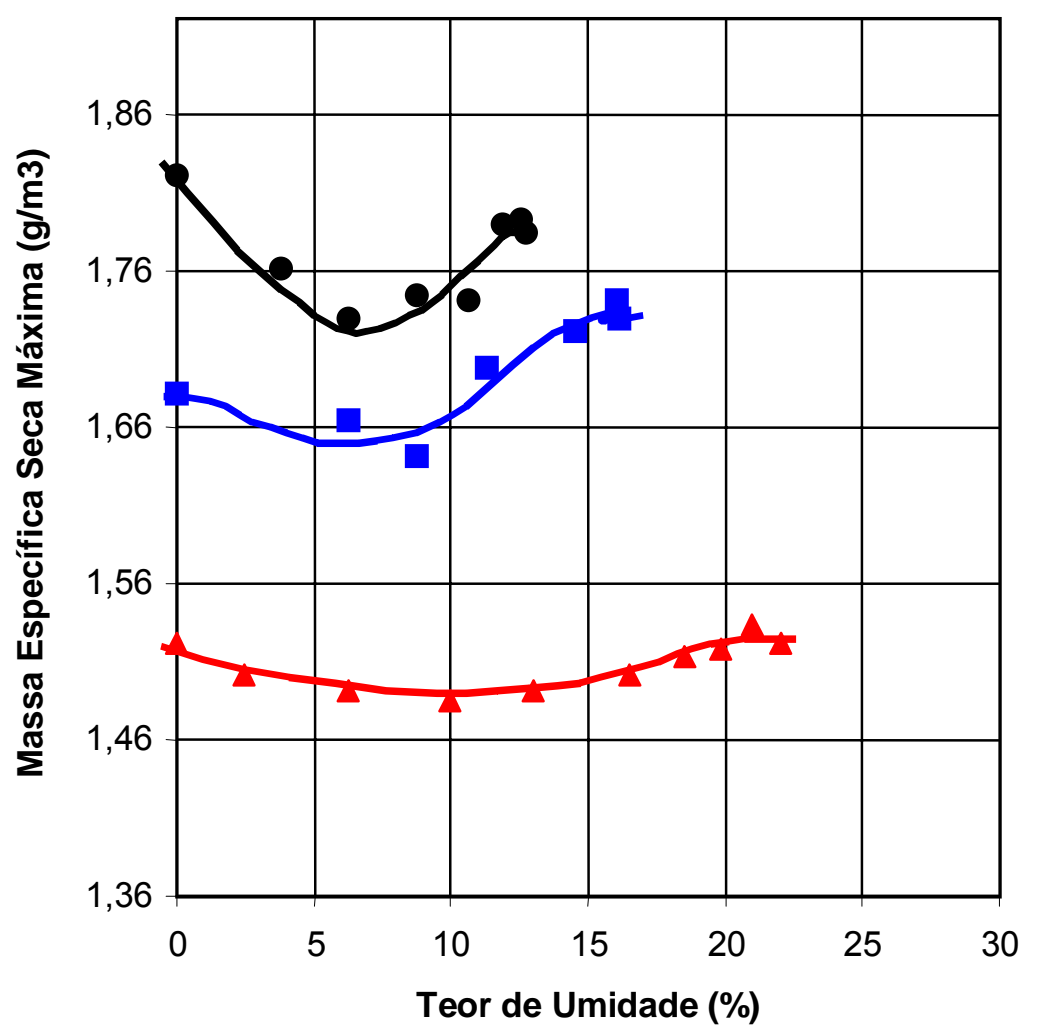

- Schahfer Unid. 14ロ Gallagher $\Delta$ Schahfer Unid. 17

FIGURA 2.4 - Curvas de compactação típicas das cinzas pesadas (LOVELL et al., 1991).

Geralmente, as cinzas pesadas apresentam massa específica seca máxima 10 a $25 \%$ menores do que a dos materiais tipicamente granulares. $\mathrm{A}$ umidade ótima, por outro lado, é normalmente maior nas cinzas pesadas do que nos materiais granulares convencionais (FEDERAL HIGHWAY ADMINISTRATION, 1998).

As faixas de valores obtidas em pesquisas desenvolvidas por vários autores, para as variações entre massa específica seca máxima e umidade ótima, foram relativamente semelhantes. Segundo Usmen et al. (1983), a massa específica seca máxima da cinza pesada pode variar de $1,121 \mathrm{~g} / \mathrm{cm}^{3}$ a 
$1,842 \mathrm{~g} / \mathrm{cm}^{3}$, enquanto que a umidade ótima pode apresentar valores na faixa entre 15 e 30\%. Lovell et al. (1991), por sua vez, obtiveram valores de massa específica seca máxima de 1,537 a $1,734 \mathrm{~g} / \mathrm{cm}^{3}$ e umidade ótima variando entre 12 e 24\%. Já Pandeline et al. (1997), estudando a aplicação de cinzas pesadas, derivadas da queima de resíduos municipais, na construção de rodovias, obtiveram uma variação de 1,290 a $1,910 \mathrm{~g} / \mathrm{cm}^{3}$ na massa específica seca máxima, sendo que o teor ótimo de umidade variou de 12,6 a 20,8\%.

A saturação das amostras compactadas de cinza pesada não interfere nos valores de CBR (California Bearing Ratio), devido à natureza granular da cinza. Lovell et al. (1991) seguiram o procedimento de ensaio proposto pela AASHTO T193 para determinação do CBR e obtiveram valores entre 40 e $70 \%$ para três cinzas pesadas do estado de Indiana. Comparando os resultados obtidos com os valores de CBR de solos típicos americanos e materiais para base de pavimentos, as cinzas pesadas foram classificadas como materiais bons para sub-bases e bases de pavimentos. A pesquisa desenvolvida por Majizadeh et al. (1979) apresentou a mesma faixa de variação nos valores de CBR obtidos por Lovell et al. (1991). A tabela 2.8 mostra os valores de CBR obtidos por Lovell et al. (1991).

Entretanto, Ramme e Tharaiyil (1999) descrevem que as cinzas pesadas provenientes da "Wisconsin Energy Company" apresentam valores de CBR iguais a $30 \%$.

Ramme e Tharaiyil (1999) também verificaram que para se obter a mesma deflexão na superfície da camada de base, a camada com cinza pesada deveria ter uma espessura igual a duas vezes a espessura de uma camada de base granular. E para se atingir o mesmo nível de tensão no topo do subleito, essa espessura de camada, quando da utilização da cinza, deveria ser igual a 1,5 a espessura de uma base com agregado convencional. 
TABELA 2.8 - Faixa dos valores de CBR das cinzas pesadas americanas (LOVELL et al., 1991).

\begin{tabular}{|c|c|c|c|}
\hline \multirow{2}{*}{$\begin{array}{c}\text { Procedência da } \\
\text { Cinza Pesada }\end{array}$} & \multirow{2}{*}{ Teor de Umidade Inicial (\%) $^{(\mathrm{a})}$} & \multicolumn{2}{|c|}{ CBR } \\
\cline { 2 - 4 } & & Condição das Amostras \\
\cline { 2 - 4 } & 0,2 & 40 & 53 \\
\cline { 2 - 4 } & 8.5 & 47 & 46 \\
\cline { 2 - 4 } & 10.6 & 51 & 47 \\
\cline { 2 - 4 } & 12.8 & 51 & 52 \\
\cline { 2 - 4 } & 14.1 & 52 & 47 \\
\cline { 2 - 4 } & 0,4 & 70 & 53 \\
\cline { 2 - 4 } & 13,8 & 67 & 53 \\
\cline { 2 - 4 } & 17,4 & 56 & 54 \\
\hline
\end{tabular}

(a) Teor de umidade na compactação.

A figura 2.5 apresenta as variações nos valores de CBR com o aumento do teor de umidade de compactação e com a condição de saturação das amostras compactadas estudadas por Lovell et al. (1991). Por meio desta figura, é possível observar que os valores de CBR, na condição saturada, são menores que para as amostras ensaiadas na condição não saturada, diminuindo gradativamente, até certo ponto, com o aumento da umidade. A partir daí, os valores de CBR na condição saturada apresentam um aumento significativo, atingindo um pico de máximo, e diminuem novamente com o aumento do teor de umidade.

Nas amostras ensaiadas na condição não saturada, as curvas de CBR "versus" teor de umidade apresentaram comportamentos diferentes e irregulares. A curva de compactação para a cinza proveniente da usina de "Gibson" foi semelhante a curva obtida para a cinza desta mesma usina na condição saturada. Já a cinza da usina de "Schahfer 14" apresentou um aumento crescente dos valores de CBR com o aumento do teor de umidade, sendo que para o mesmo teor de umidade inicial de compactação $(0,2 \%)$, o CBR na condição não saturada foi cerca de $13 \%$ menor do que para a amostra ensaiada na condição saturada. 
A cinza pesada da usina de "Schahfer 17" apresentou uma curva de CBR na condição não saturada "versus" teor de umidade irregular. Inicialmente, o valor de CBR aumenta com o aumento do teor de umidade e em seguida diminui para depois apresentar um novo aumento atingindo um pico de valor máximo. Por fim, o aumento da umidade conduz a uma redução considerável no valor de CBR.

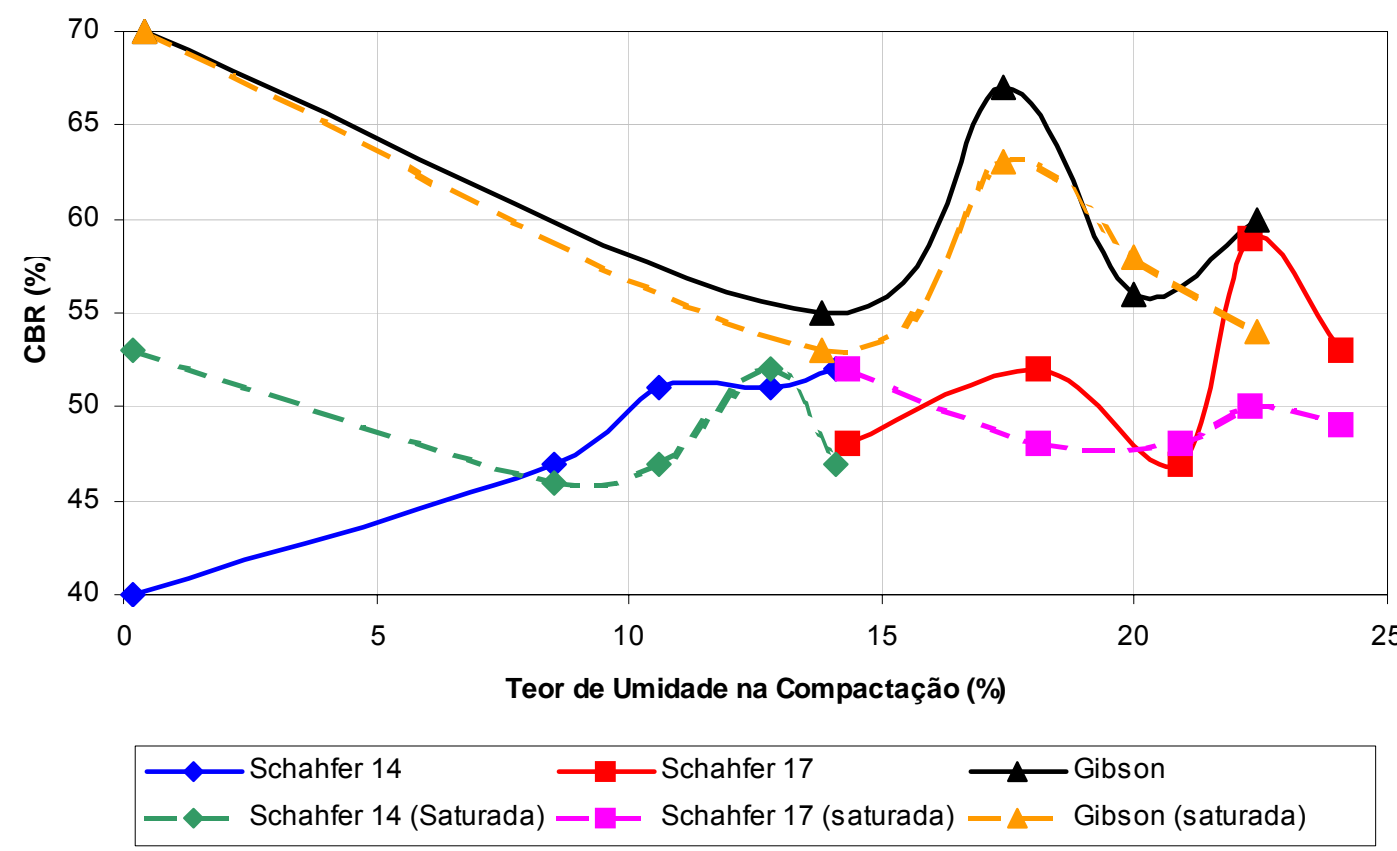

FIGURA 2.5 - Variação do CBR com o teor de umidade de compactação e condição de saturação das amostras compactadas (adaptado de LOVELL et al., 1991).

Segundo Gress et al. (1992), a cinza pesada apresenta um desgaste elevado por causa da fragilidade de suas partículas vítreas. Isso foi verificado através do ensaio de abrasão "Los Angeles", onde o resíduo apresentou um desgaste de $50 \%$. O valor elevado pode ser explicado também devido à severidade do ensaio.

Normalmente, as cinzas pesadas exibem através do ensaio de abrasão "Los Angeles", um desgaste menor do que 45\%, satisfazendo as especificações da ASTM D1241 e da AASHTO M147 para agregados para base e sub-base (LOVELL et al., 1991). Os valores obtidos por estes pesquisadores e por Moulton (1973) foram praticamente os mesmos, ou seja, os valores de abrasão "Los Angeles" variaram de 30 a $50 \%$. 
Na pesquisa de Lovell et al. (1991), avaliou-se o índice de desgaste da cinza através da relação entre o valor de abrasão "Los Angeles" após 100 revoluções do equipamento de teste e o valor obtido após 500 revoluções. Esse índice indica a uniformidade de resistência à abrasão do material. Um índice igual a 0,2 representa uma resistência uniforme do material testado. Os índices obtidos para as onze cinzas pesquisadas apresentaram valores entre 0,28 e 0,39 , indicando que a maior parte das partículas quebrou durante 0 estágio inicial do teste, mostrando a fragilidade das partículas constituintes.

As cinzas pesadas também sofrem degradação granulométrica durante o ensaio de compactação Proctor. Essa degradação foi avaliada por Lovell et al. (1991) para amostras de cinzas compactadas no teor ótimo de umidade. Para quantificar a degradação, o aumento na porcentagem de finos e o índice de esmagamento foram determinados. A tabela 2.9 mostra os resultados obtidos.

TABELA 2.9 - Degradação granulométrica das cinzas pesadas sob compactação e abrasão "Los Angeles" (adaptado de LOVELL et al., 1991).

\begin{tabular}{|c|c|c|c|c|c|}
\hline $\begin{array}{c}\text { Procedência } \\
\text { da Cinza } \\
\text { pesada }\end{array}$ & $\begin{array}{c}\text { Antes da } \\
\text { Compact. }\end{array}$ & $\begin{array}{c}\text { Depois da } \\
\text { Compact. }\end{array}$ & $\begin{array}{c}\text { Aumento } \\
(\%)\end{array}$ & $\begin{array}{c}\text { Índice de } \\
\text { Esmagamento } \\
(\%)\end{array}$ & $\begin{array}{c}\text { Abrasão } \\
\text { "Los } \\
\text { Angeles" } \\
(\%)\end{array}$ \\
\hline Schahfer 14 & 0,3 & 0,4 & 33,33 & 4,8 & - \\
\hline Schahfer 17 & 2,5 & 3,5 & 40,00 & 11,5 & 38 \\
\hline Gibson & 6,1 & 6,5 & 6,56 & 10,0 & 34 \\
\hline Gallagher & 9,4 & 10,1 & 7,45 & 5,1 & 37 \\
\hline Perry & 2,4 & 5,9 & 145,83 & 32,6 & 48 \\
\hline $\begin{array}{c}\text { Agregado } \\
\text { granular de } \\
\text { pedra } \\
\text { calcária }\end{array}$ & 3,0 & 6,0 & 100,00 & 4,9 & - \\
\hline $\begin{array}{c}\text { Agregado } \\
\text { natural de } \\
\text { rio }\end{array}$ & 1,0 & 3,0 & 200,00 & 6,5 & - \\
\hline
\end{tabular}

Com exceção da cinza da usina de "Perry", para as demais amostras o aumento na porcentagem de finos após a compactação da cinza foi menor do que os apresentados por materiais granulares. Contudo, por causa da 
fragilidade e da porosidade das partículas, o índice de esmagamento foi, geralmente, maior do que os exibidos pelos agregados granulares.

Uma série de ensaios de cisalhamento direto foi executada por Lovell et al. (1991), com nível de tensão variando de 33 a $227 \mathrm{kPa}$, para as cinzas pesadas do estado americano de Indiana. Através dos ensaios e assumindo como envoltória de ruptura a de "Mohr-Coulomb", os pesquisadores obtiveram o ângulo de atrito e o intercepto coesivo das amostras estudadas.

A maior parte das amostras de cinza pesada apresentou ângulo de atrito maior que os dos solos. As amostras das cinzas foram ensaiadas nas condições compactada e solta. Para a condição compactada, os ângulos de atrito variaram de 46 a $55^{\circ}$ e, no estado solto, os valores obtidos ficaram entre 35 a $45^{\circ}$. Por causa da natureza granular da cinza, o intercepto coesivo das amostras ensaiadas foi relativamente baixo, variando de 0,93 a 3,20 kPa para condição solta e de 9,93 a 20,80 kPa na condição compactada.

As cinzas pesadas apresentam, geralmente, ângulos de atrito ligeiramente maiores do que os apresentados por solos granulares. Isso se deve, provavelmente, ao fato de que as cinzas exibem textura mais áspera e angular (FEDERAL HIGHWAY ADMINISTRATION, 1998). Nos estudos realizados por Majizadeh et al. (1979), os valores de ângulo de atrito variaram entre 38 e $42^{\circ}$. No entanto, Ramme e Tharaniyil (1999), através do mesmo ensaio de cisalhamento direto, obtiveram $40^{\circ}$ para o ângulo de atrito da cinza compactada e um intercepto coesivo de 35,91 KPa. Contudo, os pesquisadores esperavam obter um intercepto coesivo igual a zero, uma vez que a cinza se assemelha muito a uma areia siltosa. Estes autores também verificaram que no inverno, devido ao congelamento da água, a camada compactada de cinza pesada apresentou uma expansão de $0,4 \%$, mas durante o período de degelo a expansão diminuiu para $0,1 \%$.

Dechamps (1997), estudando as cinzas provenientes das caldeiras tipo AFBC, realizou ensaios de cisalhamento direto e, a partir dos resultados 
obtidos de ângulo de atrito, concluiu que este tipo de material poderia ser empregado na construção de taludes com inclinação típica de $26,5^{0}$ (1:2).

As cinzas pesadas provenientes da queima de resíduos sólidos municipais apresentam, quando comparadas com as cinzas resultantes da queima do carvão mineral, valores semelhantes de ângulo de atrito na condição compactada, contudo, os resultados de intercepto coesivo são consideravelmente distintos. Isto foi relatado por Pandeline et al. (1997) no estudo realizado com cinzas pesadas resultantes de dois processos diferentes de combustão de resíduos: "Mass-burn" (MB) e "Refuse-Derived-Fuel" (RDF).

Os interceptos coesivos para as amostras dos dois tipos de cinza também foram relativamente pequenos, como já citado anteriormente, sendo que desta vez as cinzas apresentaram uma variação para esse parâmetro de 13,8 a 34,5 KPa. Segundo Pandeline et al. (1997), esses valores de intercepto coesivo são resultado da atividade pozolânica das cinzas, que proporciona a cimentação das partículas do material.

O ângulo de atrito é função do grau de compactação e do tamanho dos grãos. Quando a energia de compactação é mantida constante, a cinza pesada passante na peneira $n^{0} 4$ tende a apresentar intercepto coesivo e ângulo de atrito maiores que a cinza passada na peneira $n^{0} 8$. Tanto as cinzas provenientes do processo MB como do RDF exibiram um aumento de 2 a $7^{0}$ no ângulo de atrito com o aumento do grau de compactação, sendo que a cinza MB apresentou ângulos ligeiramente maiores. Por meio da figura 2.6, é possível verificar que o ângulo de atrito das cinzas aumenta com o aumento da massa específica seca. 


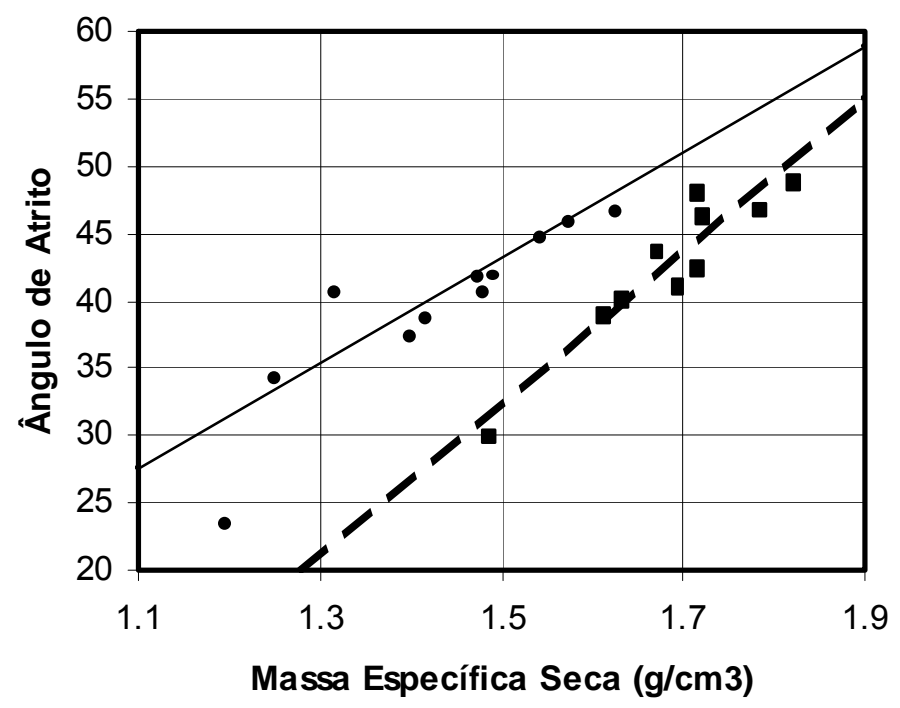

$\longrightarrow$ Cinza MB $\left(R^{\wedge} 2=0,917\right) \longrightarrow$ Cinza $\operatorname{RDF}\left(R^{\wedge} 2=0,817\right)$

FIGURA 2.6 - Ângulo de atrito "versus" massa específica seca de cinzas pesadas resultantes dos processos de queima MB e RDF (PANDELINE et al., 1997).

A figura 2.7 apresenta as curvas de tensão desvio "versus" deformação axial para as cinzas pesadas analisadas por Pandeline et al. (1997). Analisando essa figura, observa-se que, quando compactadas, as amostras de cinza apresentam um comportamento semelhante. Com o aumento da tensão desvio as deformações axiais exibidas pelas amostras densamente compactadas foram menores do que as apresentadas pelas amostras ensaiadas na condição "solta" (não densamente compactada).

Após a aplicação da tensão desvio de aproximadamente 280 KPa e 210 $\mathrm{KPa}$ para as amostras $\mathrm{MB}$ e RDF, respectivamente, no estado solto, as deformações axiais apresentaram um aumento crescente, indicando o rompimento das amostras. As amostras ensaiadas na condição compactada só atingiram o rompimento após a aplicação de tensão desvio de, aproximadamente, $560 \mathrm{KPa}$ (PANDELINE et al., 1997).

As amostras densamente compactadas apresentaram aumento na deformação volumétrica com o aumento na deformação axial, enquanto que as amostras no estado solto primeiro diminuíram de volume, para depois apresentarem um ligeiro aumento (figura 2.8). 


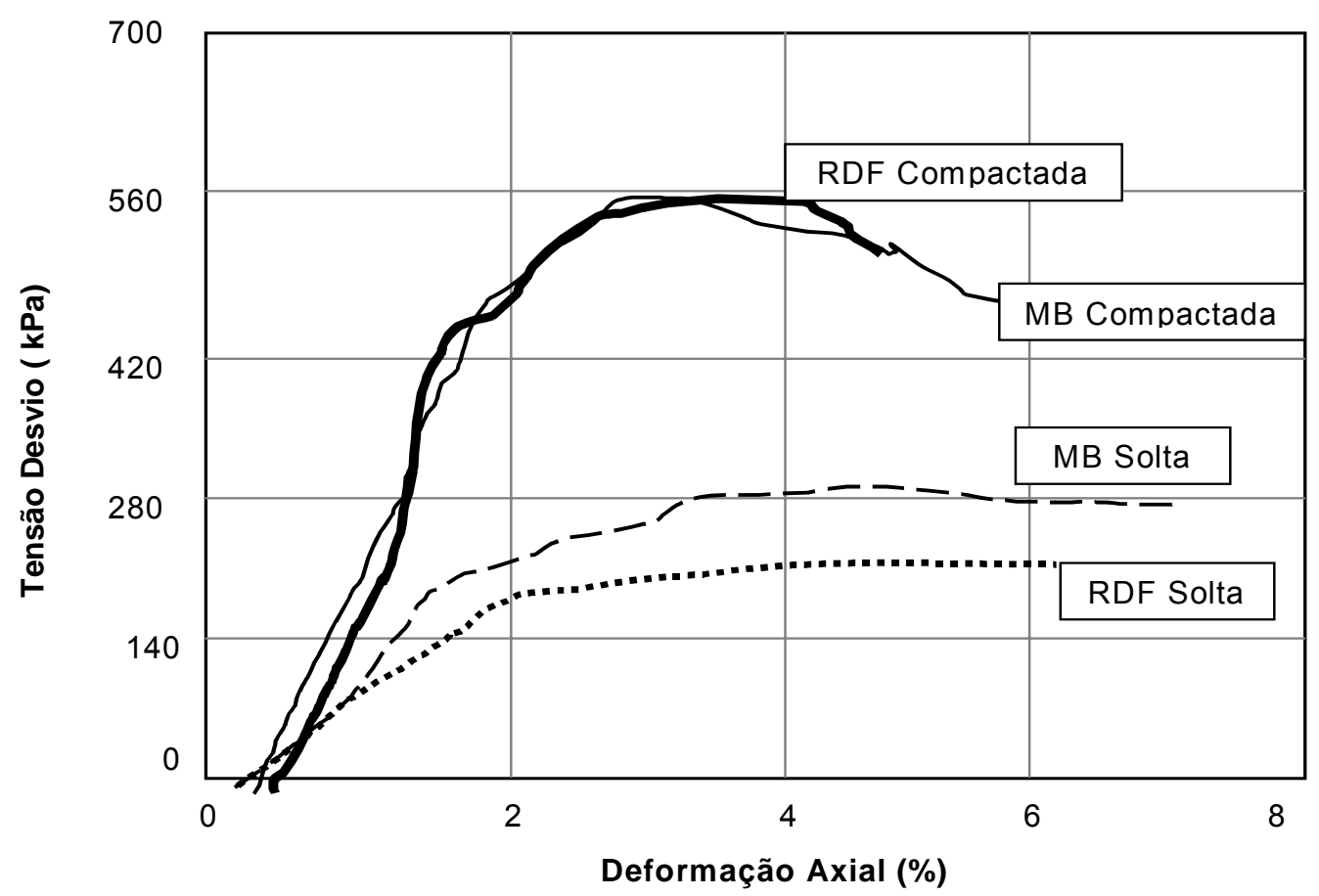

FIGURA 2.7 - Curvas deformação axial "versus" tensão desvio das cinzas pesadas resultantes dos processos de queima MB e RDF (PANDELINE et al., 1997).

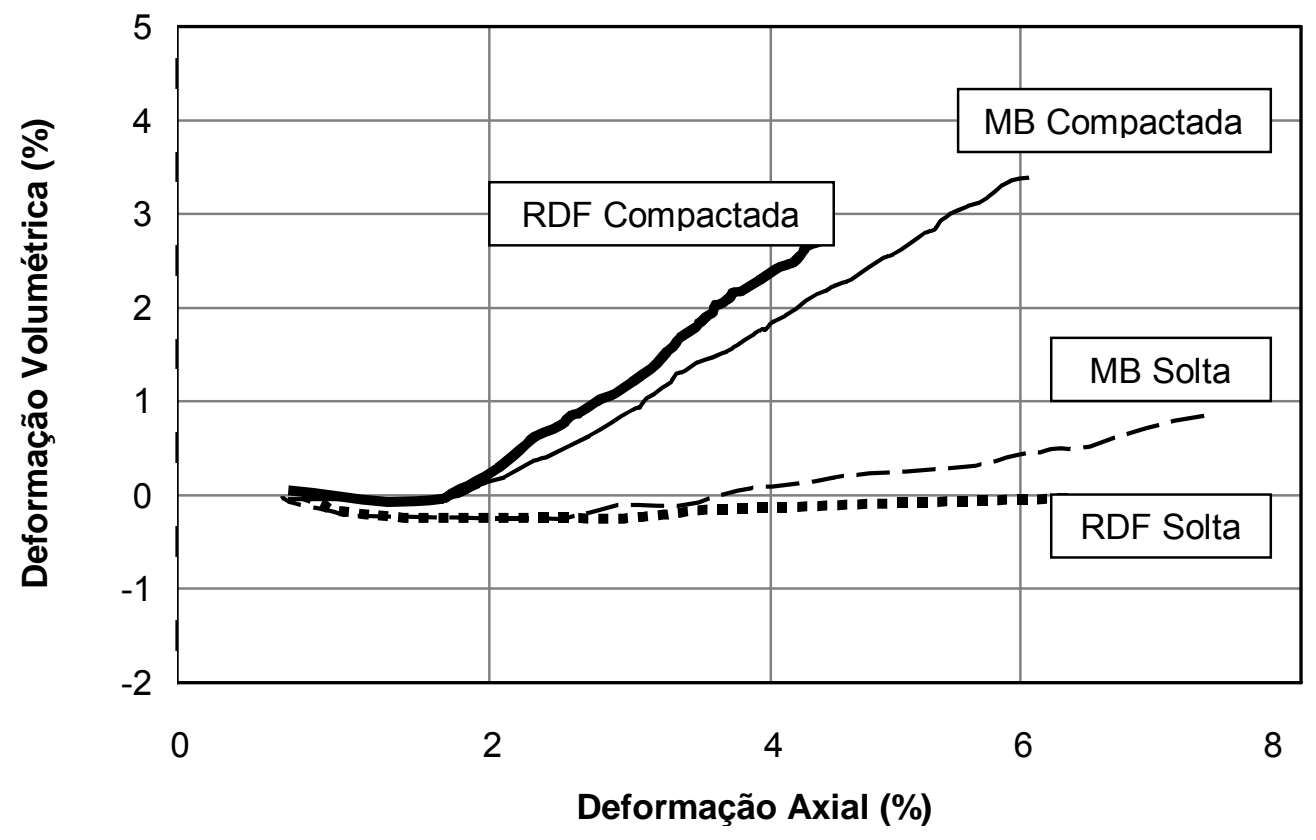

FIGURA 2.8 - Curvas de deformação axial "versus" deformação volumétrica das cinzas pesadas resultantes dos processos de queima MB e RDF (PANDELINE et al., 1997).

Algumas pesquisas já relataram a melhora de desempenho da cinza pesada, com respeito ao seu comportamento mecânico, devido às reações pozolânicas. Deste modo, Pandeline et al. (1997) realizaram ensaios de 
compressão simples em amostras de cinzas pesadas do tipo MB e RDF. As amostras foram compactadas e ensaiadas após 120 dias de cura. A amostra de cinza MB ensaiada imediatamente após a compactação apresentou uma resistência à compressão simples de aproximadamente $134,37 \mathrm{KPa}$, enquanto que a amostra ensaiada após o envelhecimento exibiu uma resistência à compressão simples de quase $689,47 \mathrm{KPa}$. Este comportamento caracteriza, desta forma, que realmente ocorre reação pozolânica e que, conseqüentemente, há um aumento da resistência à compressão das cinzas ao longo do tempo.

A forma da curava de resistência à compressão simples versus teor de umidade da cinza pesada compactada é bastante similar a de solos granulares, uma vez que esta resistência é maior para umidades pouco abaixo do teor de umidade ótimo e com energia de compactação maior.

Por meio da figura 2.9, é possível notar que os maiores valores de resistência à compressão simples ocorrem para as energias de compactação maiores e as amostras compactadas apresentam valores maiores de resistência no ramo seco da curva de compactação (PANDELINE et al., 1997).

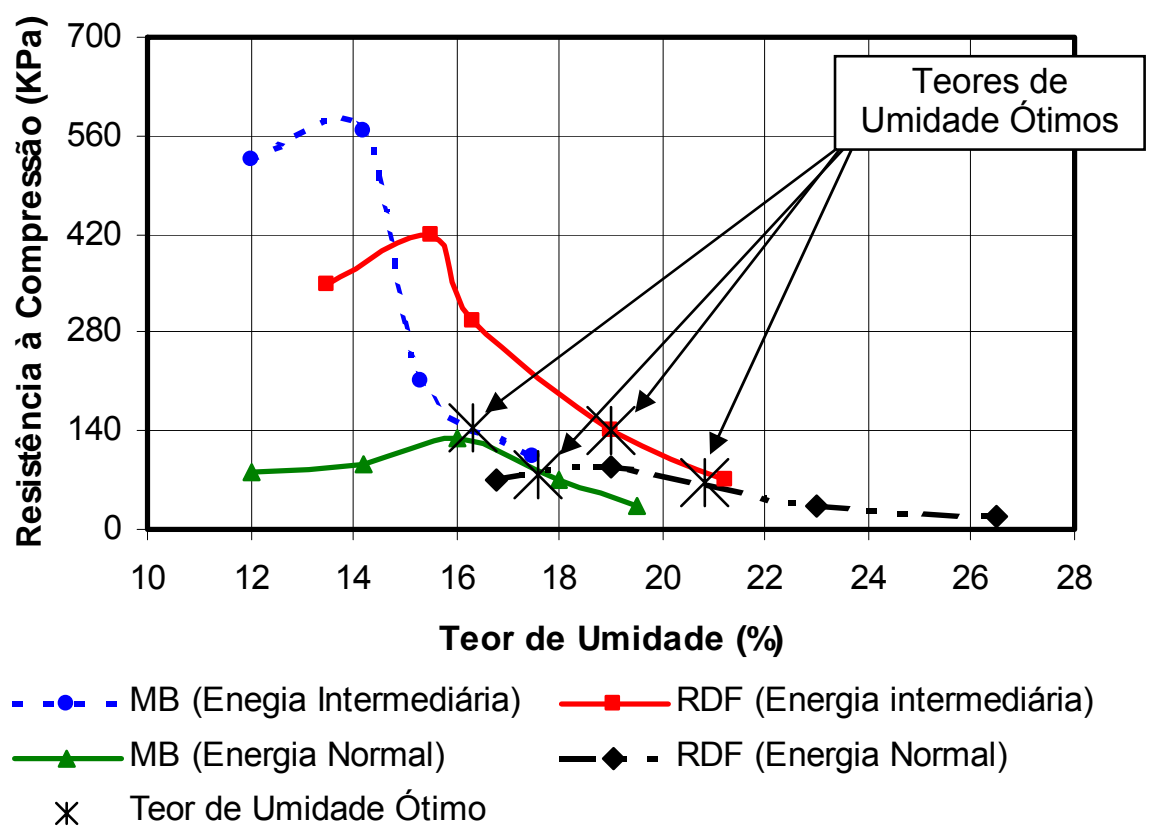

FIGURA 2.9 - Resistência à compressão simples "versus" teor de umidade das cinzas pesadas resultantes dos processos de queima MB e RDF (PANDELINE et al., 1997). 


\section{4 - MISTURAS COMPACTADAS CONTENDO CINZA PESADA}

\subsection{1 - Cinza Pesada com Cimento e Cinza Leve}

Nunes e Dawson (1997) realizaram ensaios triaxiais dinâmicos, com o objetivo de analisar o comportamento resiliente e determinar as propriedades mecânicas de cinco materiais diferentes: cinza leve e cinza pesada, areia argilosa, "Minestone" (rocha escavada durante a mineração do carvão, geralmente folhelhos), resíduos de ardósia e como material de referência o granito britado. Esses materiais foram estabilizados com cimento, cal e com a própria cinza leve. A tabela 2.10 mostra as porcentagens de cimento, cal e cinza leve usadas em cada mistura.

TABELA 2.10 - Porcentagens de cimento, cal e cinza leve utilizados na estabilização de materiais (NUNES e DAWSON, 1997).

\begin{tabular}{|c|c|c|c|c|}
\hline \multirow{2}{*}{ Agregado } & \multirow{2}{*}{ Nomenclatura } & \multicolumn{3}{|c|}{ Teor de estabilizante (\%) } \\
\cline { 3 - 5 } & & Cimento & Cal & Cinza Leve \\
\hline \multirow{2}{*}{ "Minestone" } & MIN1 & - & 5 & 12 \\
\cline { 2 - 5 } & MIN4 & - & 3 & 8 \\
\hline \multirow{3}{*}{ Areia argilosa } & CCS2 & 2 & - & - \\
\cline { 2 - 5 } & CCS4 & 2 & - & - \\
\cline { 2 - 5 } & CCS6 & - & - & - \\
\hline $\begin{array}{c}\text { Resíduos de } \\
\text { Ardósia }\end{array}$ & SW1 & - & - & - \\
\hline \multirow{2}{*}{\begin{tabular}{c} 
Cinza Leve \\
\cline { 2 - 5 }
\end{tabular}} & PFA2 & 2 & - & - \\
\hline Cinza Pesada & FBA3 & 5 & - & - \\
\cline { 2 - 5 } & FBA4 & 2 & - & - \\
\hline $\begin{array}{c}\text { Granito } \\
\text { britado }\end{array}$ & GRA1 & - & - & - \\
\hline
\end{tabular}

A figura 2.10 representa a evolução de tensões da cinza pesada com adição de $2 \%$ de cimento, curada por um período de 28 dias e 0 comportamento de um material tipicamente granular.

Através deste gráfico, Nunes e Dawson (1997) verificaram que a cinza estabilizada com $2 \%$ de cimento apresenta um comportamento tensão "versus" deformação semelhante ao do material granular. A principal diferença é a 
quantidade de energia dissipada durante um ciclo de carregamento, que parece ser reduzida para a cinza tratada com cimento, uma vez que esta mistura apresenta um ciclo de histerese mais estreito do que para o material granular (rejeito de ardósia, SW1). A figura 2.11 mostra que a cinza pesada tratada com $2 \%$ de cimento apresentou uma resistência à ruptura à compressão simples maior do que para o granito britado (GRA1), quando empregada uma tensão confinante igual a zero.

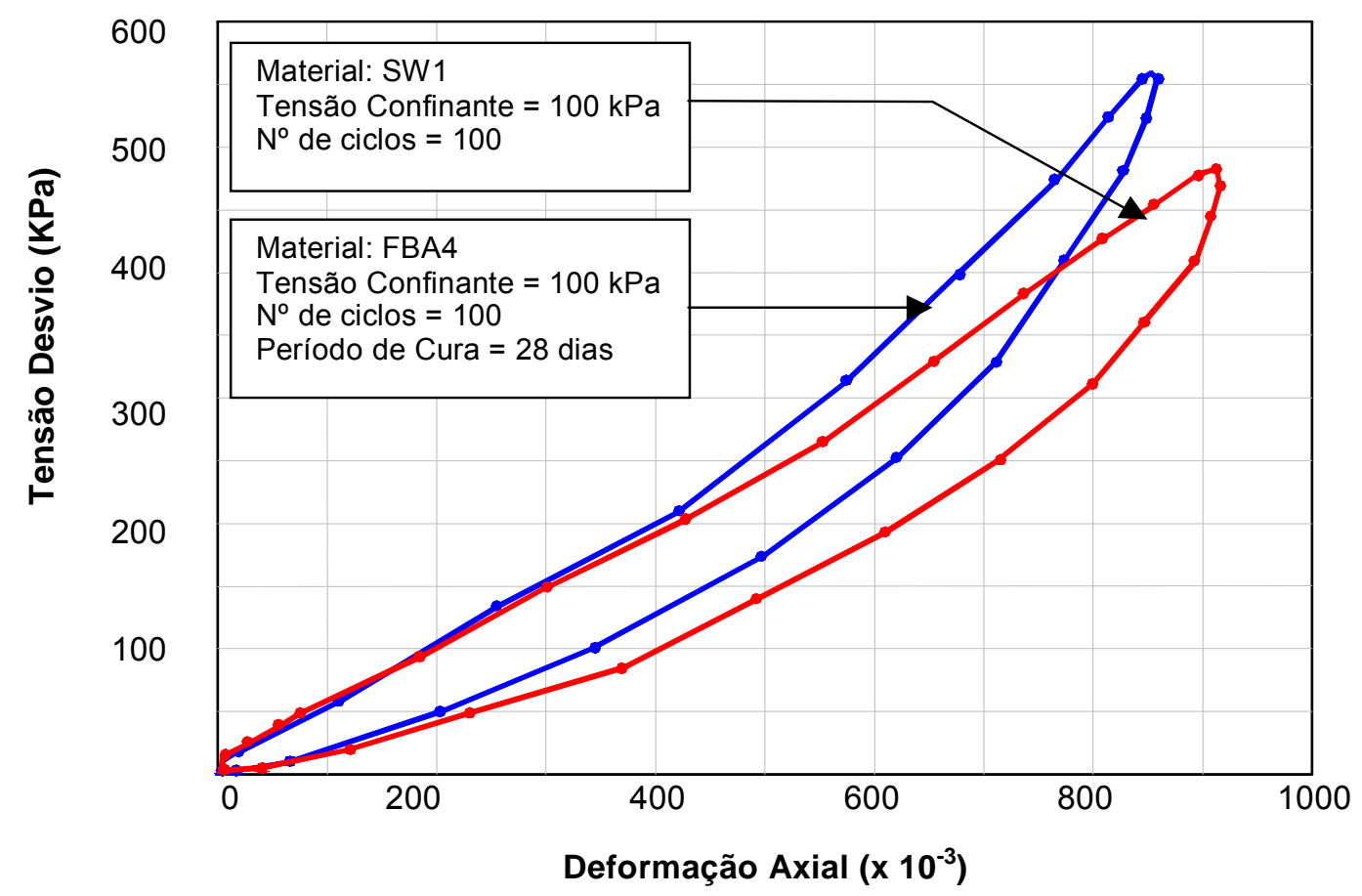

FIGURA 2.10 - Trajetória de tensões da cinza pesada e de um material granular sob carregamento repetido (NUNES e DAWSON, 1997).

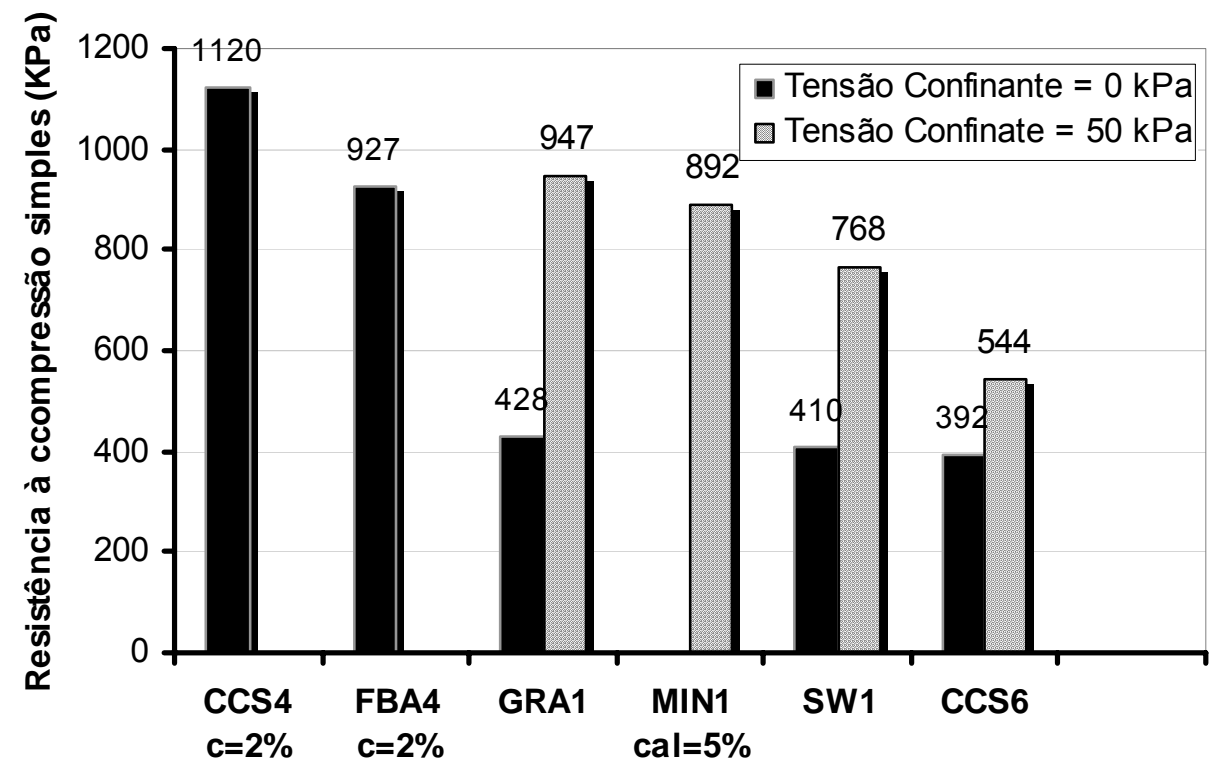

FIGURA 2.11 - Resistência à compressão simples dos materiais submetidos a carregamento triaxial (NUNES e DAWSON, 1997). 
A cinza pesada, quando não estabilizada, apresenta um módulo de resiliência de $230 \mathrm{MPa}$, que foi aumentado com a adição de $2 \%$ de cimento e, posteriormente, com a adição de $2 \%$ de cimento e $8 \%$ de cinza leve. Esse aumento fez com que o módulo de resiliência da cinza pesada com estabilizantes fosse comparado aos módulos resilientes dos materiais sem tratamento, como areia argilosa, granito britado e a ardósia. A figura 2.12 traz os valores dos módulos de resiliência obtidos para as misturas estudadas por Nunes e Dawson (1997), sendo possível verificar nela que a cinza leve com 5\% de cimento apresentou o maior valor de módulo de resiliência.

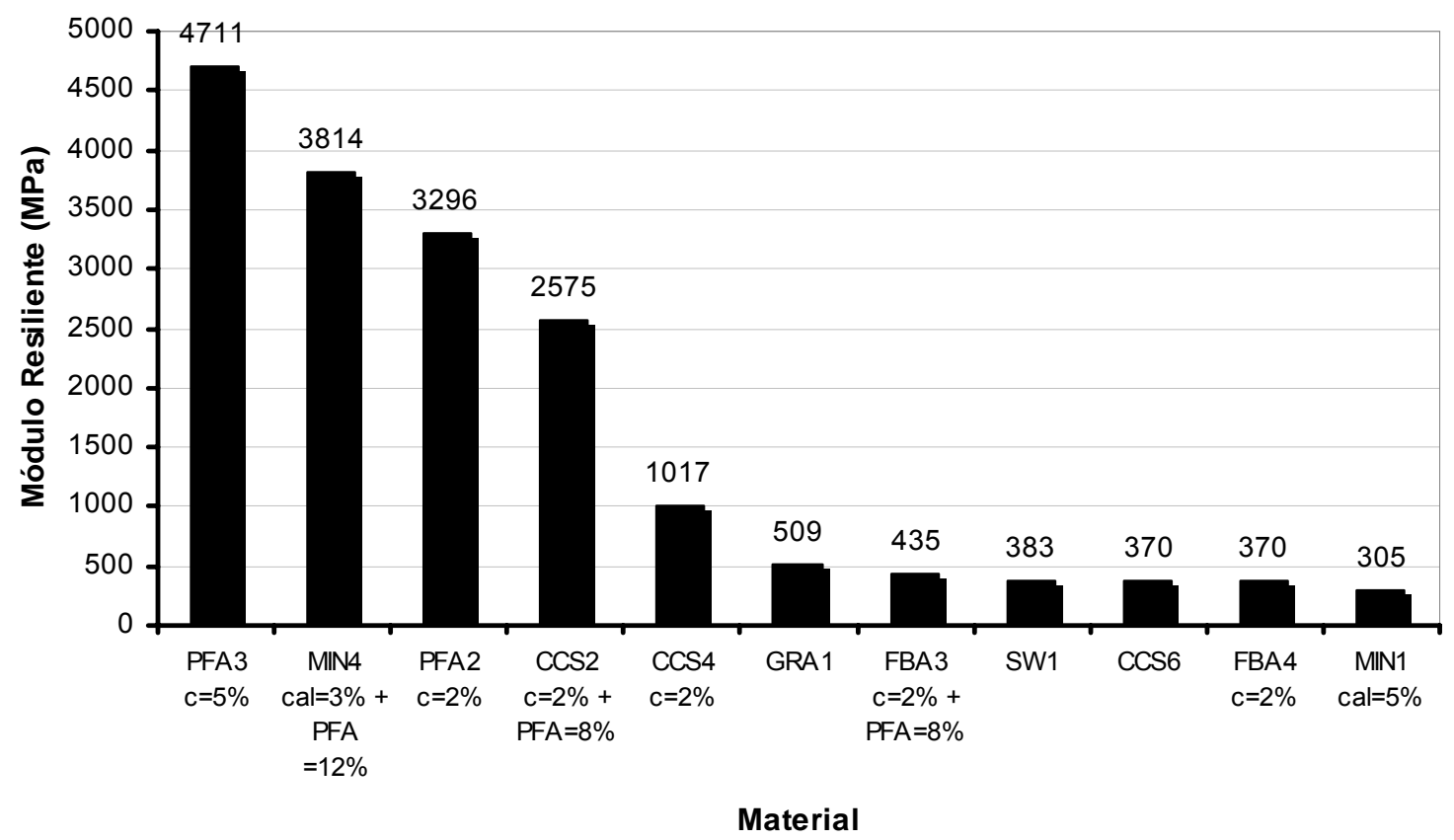

FIGURA 2.12 - Módulo de resiliência dos materiais estudados por Nunes e Dawson, 1997.

O uso de cinza leve na estabilização da "Minestone" aumentou significativamente o módulo de resiliência deste material, evidenciando a vantagem da utilização da cinza leve como material estabilizante. Além disso, proporcionou o aumento do módulo da mistura de cinza pesada e cimento. $O$ aumento nos valores dos módulos de resiliência destes materiais deve-se, possivelmente, ao fato de a cinza leve apresentar uma distribuição granulométrica mais fina, preenchendo os espaços vazios dos materiais mais granulares e, além disso, a atividade pozolânica das cinzas pode provocar a cimentação das partículas durante o período de cura. 


\subsection{2 - Cinza Pesada e Materiais Geotécnicos}

Na pesquisa desenvolvida por Ksaibati e Bowen (1999), foram utilizados os ensaios de compactação, absorção de água, "resistance value" (R-Value) e "cohesion value" (CV-Value) para avaliar a viabilidade da incorporação de cinza pesada em materiais granulares. As cinzas pesadas utilizadas na pesquisa eram provenientes de três fontes diferentes do estado americano de Wyoming, sendo que o material granular foi empregado como amostra de controle.

O R-Value é determinado através do estabilômetro de Hveem. Este equipamento mede a resistência à deformação de uma amostra compactada por meio da leitura da pressão lateral desenvolvida devido à aplicação de um carregamento vertical. Valores obtidos entre 55 e 80 caracterizam solos de boa qualidade.

O coesímetro de Hveem é utilizado para medir a coesão (CV-Value) da amostra compactada através da mensuração da força necessária para quebrar a amostra colocada no equipamento como uma viga em balanço.

O estudo consistiu em adicionar a cinza ao material granular em quatro teores para, então, realizar os ensaios laboratoriais desejados. A cinza pesada foi misturada ao material granular nas seguintes porcentagens: 0, 25, 50, 75 e $100 \%$, onde $0 \%$ de cinza pesada corresponde à amostra de controle $(100 \%$ material granular).

Os resultados obtidos foram comparados com os padrões de classificação do "Wyoming Departament of Transportation" e analisados estatisticamente. O propósito da análise estatística era determinar se os resultados obtidos para as misturas agregado/cinza apresentavam diferenças significativas em relação à amostra de controle.

Ksaibati e Bowen (1999) realizaram ensaios de absorção de água para três amostras de cinzas pesadas passadas na peneira $N^{\circ} 4$ e fizeram uma comparação com os valores de absorção obtidos para uma amostra de 
agregado convencional e para várias misturas deste agregado com os três tipos de cinzas estudadas. As porcentagens de cinzas em cada uma das misturas com agregado e os respectivos resultados estão apresentados na tabela 2.11.

TABELA 2.11 - Porcentagens de cinzas pesadas utilizadas nas misturas com agregado convencional e respectivos valores de absorção de água (KSAIBATI e BOWEN, 1999).

\begin{tabular}{|c|c|c|c|c|}
\hline Procedência & Designação & $\begin{array}{c}\text { Cinza pesada } \\
(\%)\end{array}$ & $\begin{array}{c}\text { Agregado } \\
\text { granular (\%) }\end{array}$ & $\begin{array}{c}\text { Absorção de } \\
\text { Água (\%) }\end{array}$ \\
\hline Controle & $\mathrm{H} 1$ & 0 & 100 & 2,2 \\
\hline \multirow{4}{*}{ WyoDak } & $\mathrm{A} 1$ & 100 & 0 & 2,8 \\
\cline { 2 - 5 } & $\mathrm{A} 2$ & 75 & 25 & 4,4 \\
\cline { 2 - 5 } & $\mathrm{A} 3$ & 50 & 50 & 5,4 \\
\cline { 2 - 5 } & $\mathrm{A} 4$ & 25 & 75 & 2,6 \\
\hline \multirow{4}{*}{ Jim Bridger } & $\mathrm{B} 1$ & 100 & 0 & $\mathrm{ND}$ \\
\cline { 2 - 5 } & $\mathrm{B} 2$ & 75 & 25 & 0,6 \\
\cline { 2 - 5 } & $\mathrm{B} 3$ & 50 & 50 & 0,9 \\
\cline { 2 - 5 } & $\mathrm{B} 4$ & 25 & 75 & 1,3 \\
\hline \multirow{3}{*}{ Naughton } & $\mathrm{C} 1$ & 100 & 0 & 0,9 \\
\cline { 2 - 5 } & $\mathrm{C} 2$ & 75 & 25 & 1,0 \\
\cline { 2 - 5 } & $\mathrm{C} 3$ & 50 & 50 & 1,3 \\
\cline { 2 - 5 } & $\mathrm{C} 4$ & 25 & 75 & 1,5 \\
\hline
\end{tabular}

ND" - Não determinado.

Através da tabela 2.11, é possível observar que, para as usinas de "Jim Bridger" e "Naughton", o aumento no teor de cinza nas misturas com agregado convencional para bases provocou uma diminuição na absorção de água, sendo que a absorção de água da amostra de controle (100\% material granular) permaneceu maior do que aquela apresentada por todas as misturas com cinza pesada das duas usinas acima citadas. Já as amostras procedentes da usina de "WyoDak" não apresentaram uma tendência de valores de absorção de água com a porcentagem de cinza utilizada, mas essas amostras mostraram valores de absorção maiores que os da amostra de controle.

A massa específica dos sólidos determinada para as misturas diminuiu com o aumento no teor de cinza, uma vez que a cinza apresenta menor massa especifica que o agregado granular. A massa específica dos sólidos 
para as cinzas estudadas variou de 2,12 a $2,34 \mathrm{~g} / \mathrm{cm}^{3}$, enquanto que para 0 agregado granular a massa específica obtida foi de $2,79 \mathrm{~g} / \mathrm{cm}^{3}$. Com a adição das cinzas ao agregado granular, a massa específica dos sólidos das misturas variou entre $1,99 \mathrm{~g} / \mathrm{cm}^{3}$ e $2,44 \mathrm{~g} / \mathrm{cm}^{3}$.

A massa específica seca máxima e o teor de umidade ótimo foram determinados por meio do ensaio de compactação Proctor com material passante na peneira $4,75 \mathrm{~mm}\left(\mathrm{n}^{\circ} 4\right)$. A amostra de controle $(100 \%$ material granular) foi a que apresentou maior massa específica seca máxima e menor teor de umidade ótimo. O aumento no teor de cinza adicionada ao material granular provocou uma diminuição gradativa nas massas específicas secas máximas e, ao mesmo tempo, aumentou os valores dos teores de umidade ótimos (KSAIBATI e BOWEN, 1999). Provavelmente este comportamento é reflexo da maior porosidade da cinza e da baixa massa específica das suas partículas. As figuras 2.13 e 2.14 representam o comportamento descrito acima para a massa específica seca máxima e para o teor ótimo de umidade, respectivamente.

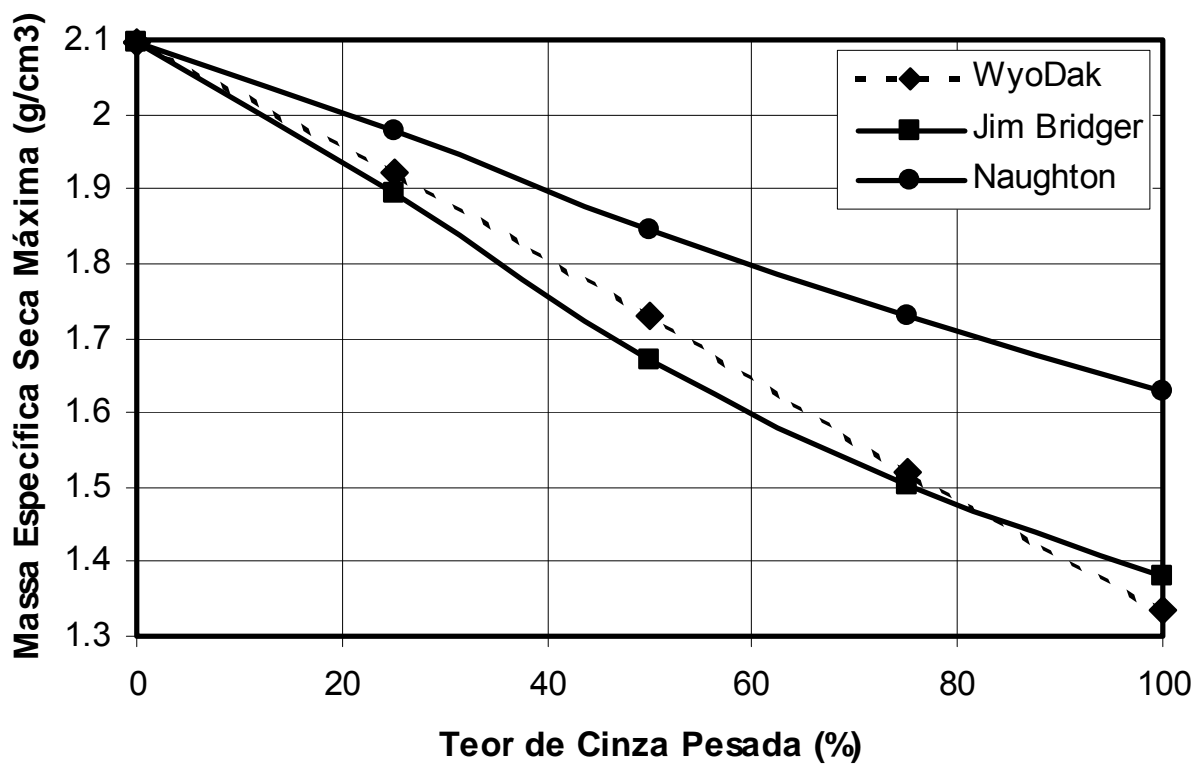

FIGURA 2.13 - Massas específicas secas máximas em função do teor e do tipo de cinza nas misturas (KSAIBATI e BOWEN, 1999). 


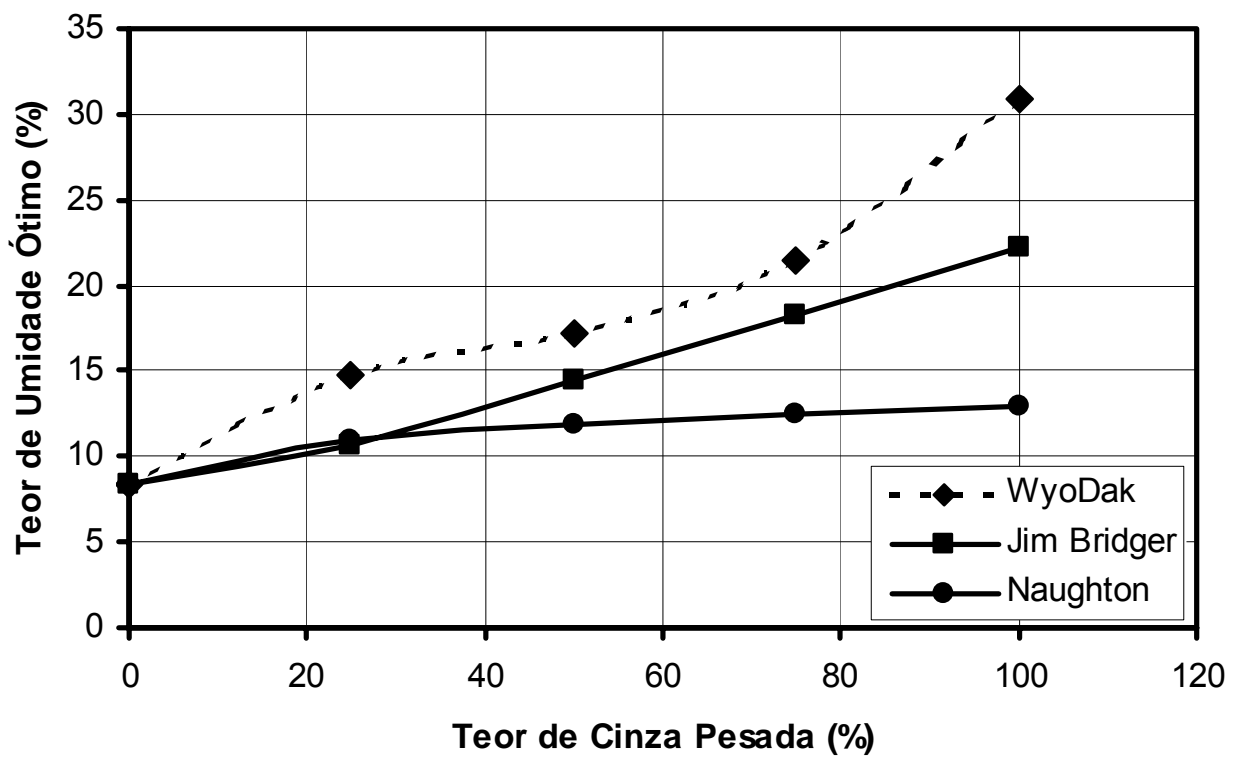

Figura 2.14 - Teores ótimos de umidade em função do teor de cinza e do tipo nas misturas (KSAIBATI e BOWEN, 1999).

Através da análise granulométrica, Ksaibati e Bowen (1999) classificaram quase todas as misturas como A-1-b, segundo o sistema de classificação de solos da AASHTO. As misturas com maior teor de cinza pesada (75\% e 100\% de cinza) das usinas de "Wyodak" e "Jim Bridger", foram classificadas como A-2-4.

Para determinar o "cohesion value", os autores utilizaram o coesímetro de Hveem. Por meio da figura 2.15, é possível verificar que a amostra de controle foi muito mais coesiva do que qualquer outra mistura. O aumento no teor de cinza adicionada à amostra de controle provocou uma grande diminuição nos valores de coesão. 


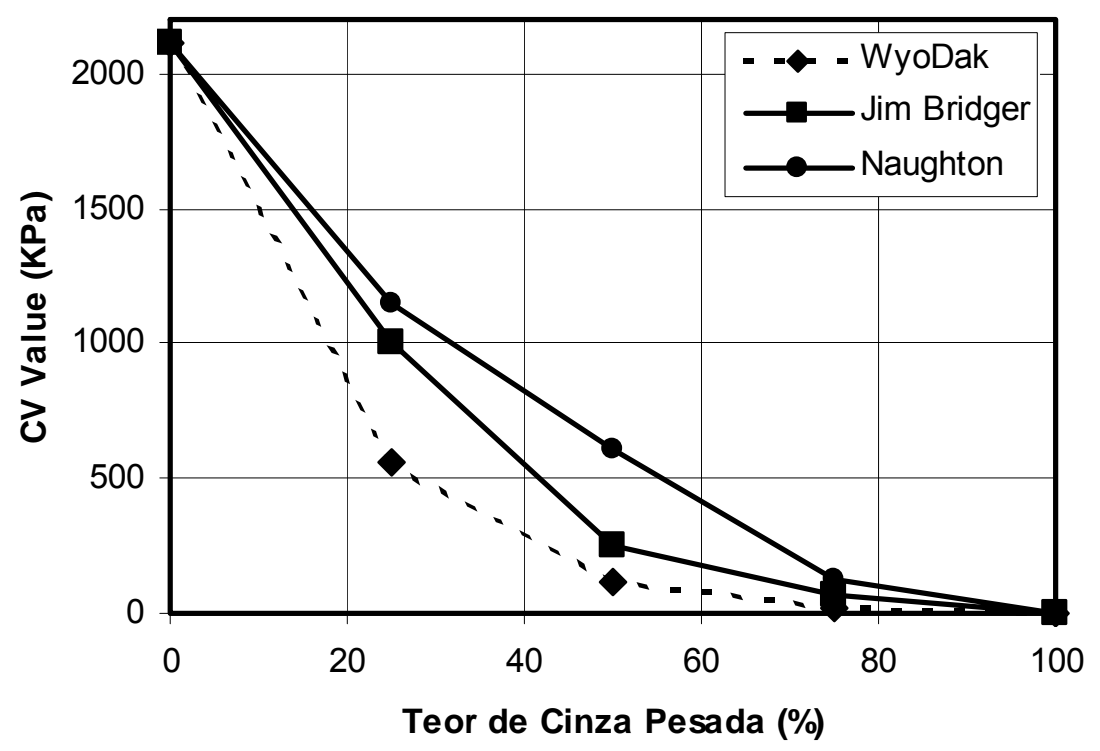

FIGURA 2.15 - Valores de "cohesion value" (CV - Value) em função do teor de cinza e do tipo nas misturas (KSAIBATI e BOWEN, 1999).

A figura 2.16 mostra a variação dos valores obtidos através do ensaio de "resistance value" (Estabilômetro de Hveem) com o aumento no teor de cinza pesada. Os valores encontrados pelos pesquisadores variaram entre 72 e 81 , indicando que as misturas são de boa qualidade. As misturas contendo $75 \mathrm{e}$ $100 \%$ de agregado granular apresentaram os maiores valores de R-Value. Contudo, percebe-se que os valores de R-Value tenderam a aumentar ou permanecer constantes até 25 a 50\% de cinza pesada, depois, para teores maiores de cinza, os valores de R-Value diminuíram gradativamente.

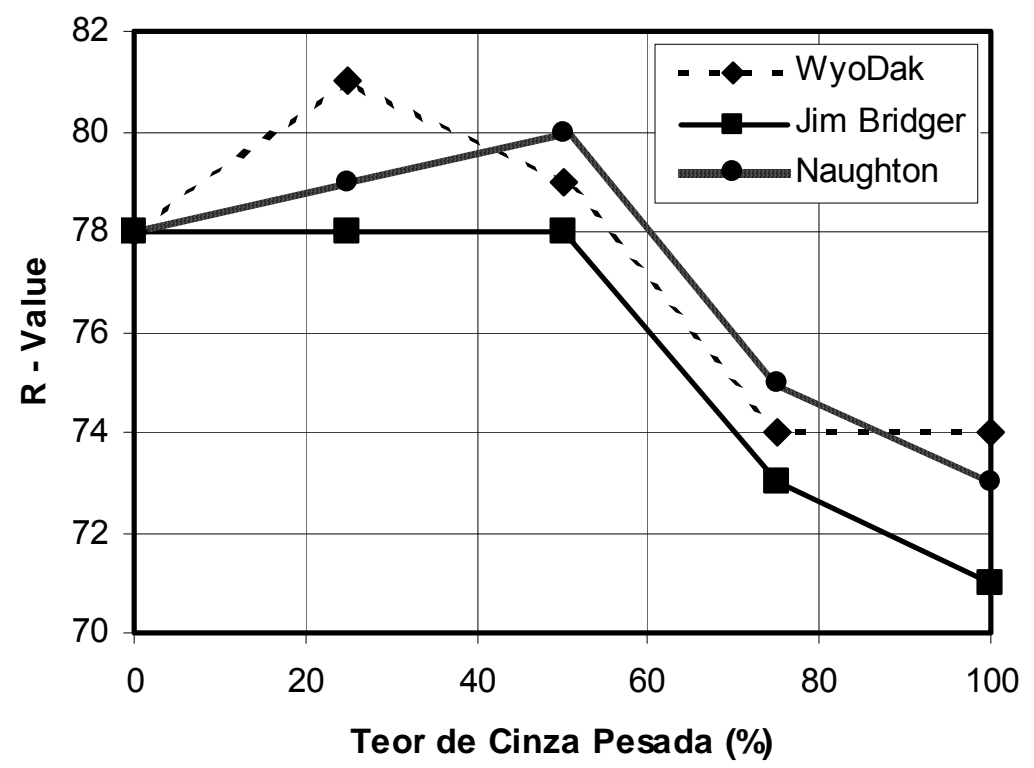

FIGURA 2.16 - Variação dos R - Value com a adição de cinza pesada ao material granular (KSAIBATI e BOWEN, 1999). 
A análise estatística feita com os resultados obtidos para as diversas misturas teve o propósito de verificar se estes resultados eram significativamente diferentes para um determinado ensaio. Por meio desta análise, Ksaibati e Bowen (1999) concluíram o seguinte:

a) As massas específicas dos sólidos para as cinzas provenientes das diferentes usinas eram estatisticamente iguais. Entretanto, a adição de cinza na amostra de controle resultou numa diminuição significativa das massas específicas dos sólidos, devido à natureza porosa da cinza;

b) A porcentagem de cinza pesada adicionada à mistura com agregado não exerce uma influência significativa sobre os valores de absorção de água e que os valores de absorção entre as cinzas pesadas e 0 agregado convencional foram estatisticamente iguais;

c) Para as misturas com $50 \%$ ou menos de cinza pesada, os $\mathrm{R}$ - Value foram estatisticamente iguais ao da amostra de controle;

d) Os CV - Value para as cinzas pesadas foram estatisticamente iguais. No entanto, a adição de cinza ao agregado granular resultou numa redução significativa da coesão global das misturas;

e) Adições de até $50 \%$ de cinza não interferem na massa específica seca máxima e nem no teor de umidade ótimo das misturas.

\section{5 - Utilização da Cinza Pesada na Construção Civil}

Na construção civil, a cinza pesada tem sido usada na fabricação de argamassas, concretos convencionais, blocos de vedação, blocos estruturais, tijolos prensados e briquetes para pavimentação. A utilização da cinza na fabricação destes produtos é realizada geralmente pela substituição dos agregados naturais ou do cimento Portland pela cinza. 


\subsection{1 - Cinza Pesada na Produção de Concretos}

A adição de cinza pesada em concretos convencionais proporciona concretos de densidades menores, devido à baixa massa específica da cinza. Além disso, na pesquisa desenvolvida por Rocha et al. (2001), a granulometria da areia empregada na confecção dos concretos apresentou uma importante melhora devido ao suprimento do material fino pelos grãos da cinza pesada. Nesse estudo, os pesquisadores avaliaram o comportamento dos concretos mediante a substituição do cimento Portland e, depois, da areia pela cinza pesada. Os teores de cinza empregados na substituição do cimento Portland foram de $0 \%, 10 \%, 20 \%$ e $30 \%$, enquanto que na substituição da areia os teores de cinza foram: $0 \%, 10 \%, 25 \%$ e $50 \%$.

O comportamento mecânico das misturas foi avaliado por meio de ensaios de resistência à compressão simples. Assim, os pesquisadores moldaram corpos de prova em um molde metálico cilíndrico de $10 \mathrm{~cm}$ de diâmetro e $20 \mathrm{~cm}$ de altura. Depois de decorridas 24 horas do processo de moldagem, os corpos de prova foram submetidos à cura úmida por meio da imersão em uma solução de água e cal, sob uma temperatura controlada de $23^{\circ} \mathrm{C}$ até a idade de rompimento à compressão axial $(3,7,28,90$ e 180 dias).

As adições de cinza pesada nos concretos proporcionaram concretos com o mesmo comportamento do concreto sem adição de cinza, ou seja, não ocorreu um decréscimo significativo na resistência à compressão simples devido à incorporação da cinza. Nas substituições da areia pela cinza, os concretos apresentaram um melhor desempenho, atingindo a partir dos 28 dias de idade maior resistência à compressão simples do que a resistência do concreto de referência (sem adição de cinza). A partir dos 90 dias de cura, a resistência à compressão simples tendeu a permanecer constante, ou seja, houve uma diminuição na taxa de aumento da resistência. A figura 2.17 apresenta os resultados de resistência à compressão simples para as amostras com substituição da areia por cinza pesada obtidos por Rocha et al. (2001). 


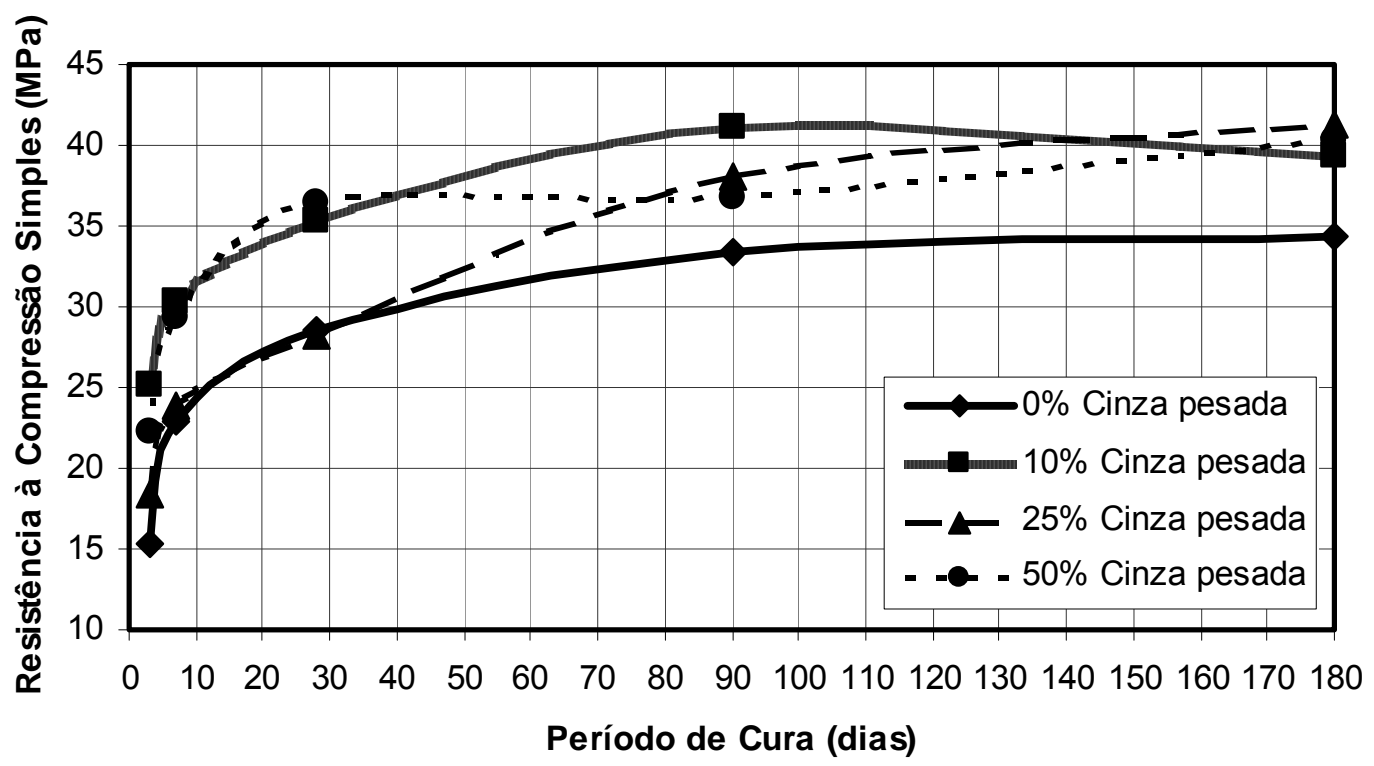

FIGURA 2.17 - Resistência à compressão simples de concretos com substituição da areia por cinza pesada (ROCHA et al., 2001).

Os concretos que tiveram os teores de cimento Portland substituídos por teores de cinza pesada apresentaram resistências menores do que a do concreto referência (figura 2.18). Segundo Rocha et al. (2001), as taxas de crescimento de resistência à compressão simples, tanto para os concretos com substituição da areia quanto para os concretos com substituição do cimento pela cinza pesada, não se diferenciaram do concreto de referência.

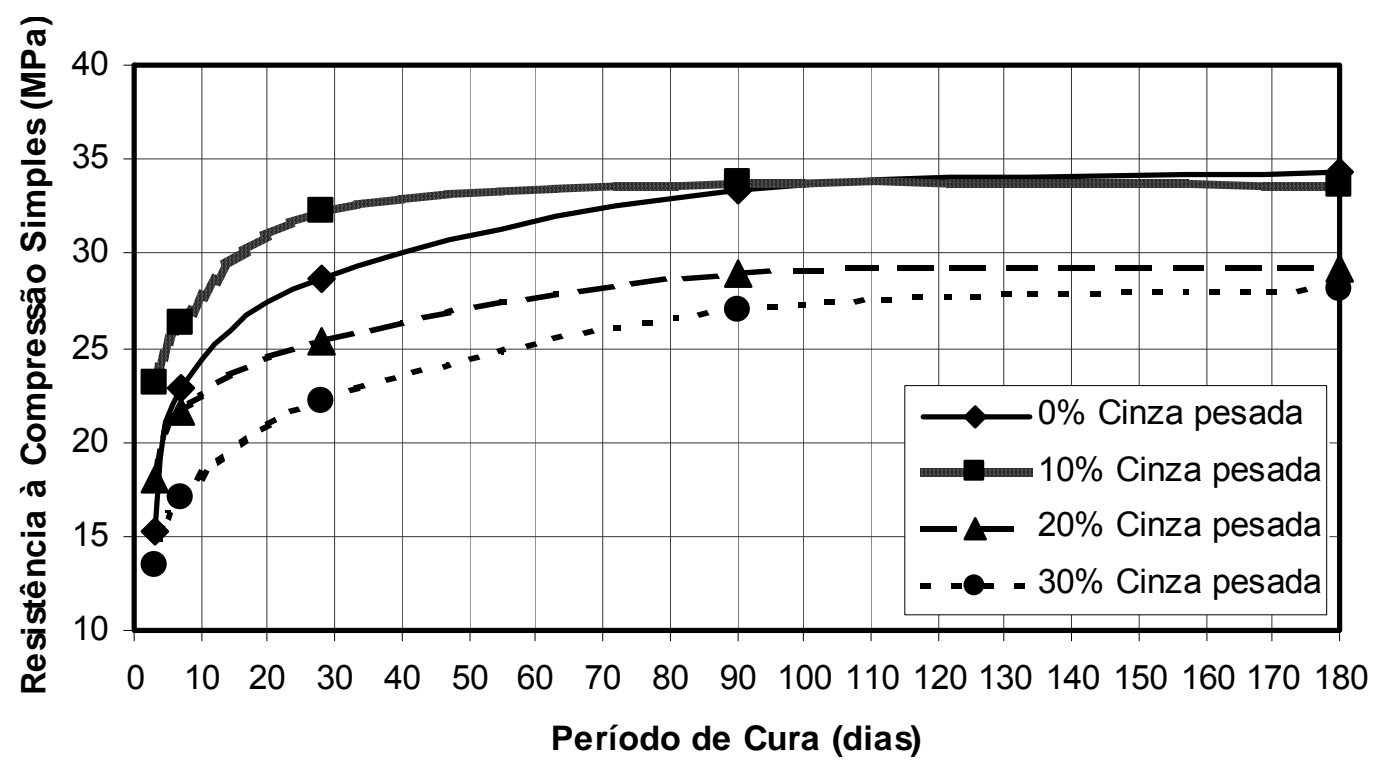

FIGURA 2.18 - Resistência à compressão dos concretos com substituição do cimento Portland por cinza pesada (ROCHA et al., 2001). 


\subsection{2 - Cinza Pesada na Fabricação de Artefatos de Concreto}

$\mathrm{Na}$ pesquisa realizada por Rocha et al. (1999), o comportamento mecânico de blocos estruturais, blocos de vedação e briquetes para pavimentação com adição de cinza pesada foi avaliado através dos ensaios de resistência à compressão simples.

Os resultados obtidos por Rocha et al. (1999), tanto para os blocos quanto para os briquetes de pavimentação, indicaram que a cinza pesada apresenta potencial suficiente para ser empregada como matéria-prima na fabricação de artefatos de concreto, tanto pelo desempenho mecânico dos artefatos quanto pela disponibilidade das cinzas geradas no complexo termelétrico Jorge Lacerda (SC).

Nos blocos estruturais, o cimento Portland foi substituído pela cinza nas seguintes porcentagens: 0\% (bloco referência), 5\% e 10\%. Os corpos de prova foram submetidos ao ensaio de resistência à compressão simples aos 7 e aos 28 dias de cura. Os resultados indicaram que as adições de cinza provocaram uma diminuição da resistência à compressão dos blocos, porém, o ganho de resistência durante o período de cura foi maior para as amostras com incorporação de cinza pesada, indicando a atividade pozolânica deste material (figura 2.19). Os briquetes destinados à pavimentação também tiveram o cimento substituído pela cinza pesada, mas em diferentes porcentagens: $0 \%$ (briquete de referência), 10\%, 20\% e 30\%. O comportamento dos briquetes foi semelhante ao dos blocos estruturais, ou seja, as adições de cinza provocaram uma diminuição da resistência à compressão simples, porém, a taxa de aumento das resistências durante o período de cura foi maior para as amostras com cinza pesada. 


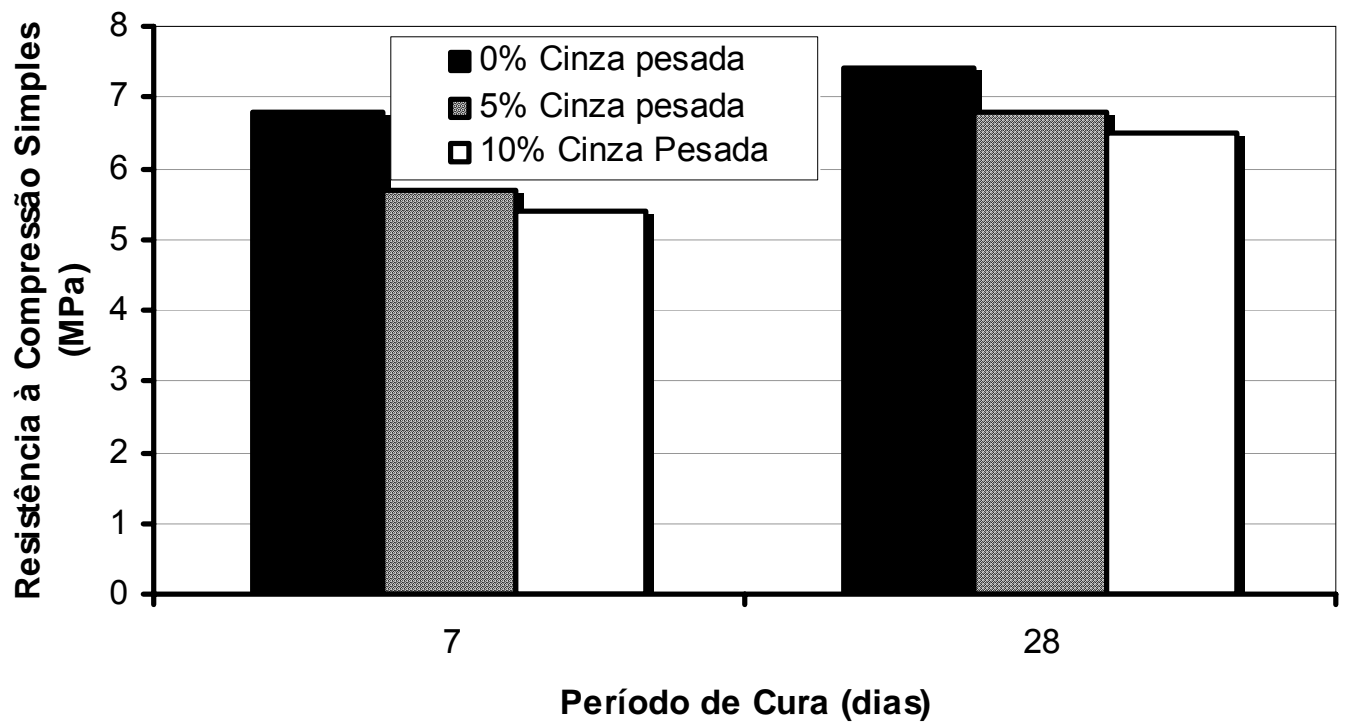

FIGURA 2.19 - Resistência à compressão simples de blocos estruturais com substituição do cimento Portland pela cinza pesada (ROCHA et al., 1999).

\subsection{3 - Cinza Pesada na Fabricação de Argamassas}

$\mathrm{Na}$ confecção de argamassas, a substituição das areias quartzosas pelas cinzas pesadas eleva a relação água/cimento. No trabalho realizado por Piazza e Rui (1999), esta relação foi $70 \%$ maior para as argamassas com adição de cinza pesada em relação às argamassas fabricadas com o emprego apenas de areias quartzosas. Esse alto valor na demanda de água de amassamento foi creditado à estrutura porosa da cinza.

Para diminuir a quantidade de água de amassamento, os autores fizeram uso de um superfluidificante e da substituição de parte da cinza pesada por cinza leve. Dessa forma, a pesquisa elaborada por Piazza e Rui (1999) consistiu na confecção de moldes prismáticos (4 x $4 \times 16 \mathrm{~cm})$ de argamassas de cimento e areia, cimento e cinza pesada, cimento e cinza pesada com $15 \%$ de cinza leve, cimento e cinza pesada com $30 \%$ de cinza leve.

Para avaliar o efeito do período de cura no desenvolvimento das reações pozolânicas e na resistência mecânica das argamassas, os corpos-de-prova que utilizaram como agregado a cinza pesada, a areia e misturas de cinza 
pesada e cinza leve foram submetidos à cura durante os períodos de 1 (ensaio imediato), 2, 3, 7, 28 e 90 dias.

A elevada relação água/cimento foi responsável pelas menores resistências à compressão e à tração por flexão dos corpos de prova contendo cinzas. Aos 28 dias de cura, as argamassas apresentaram cerca de 1/5 da resistência à compressão das argamassas elaboradas com areia quartzosa, enquanto que a resistência à tração por flexão foi cerca de $30 \%$ menor para as argamassas com cinza do que as fabricadas com areia (figura 2.20 e 2.21).

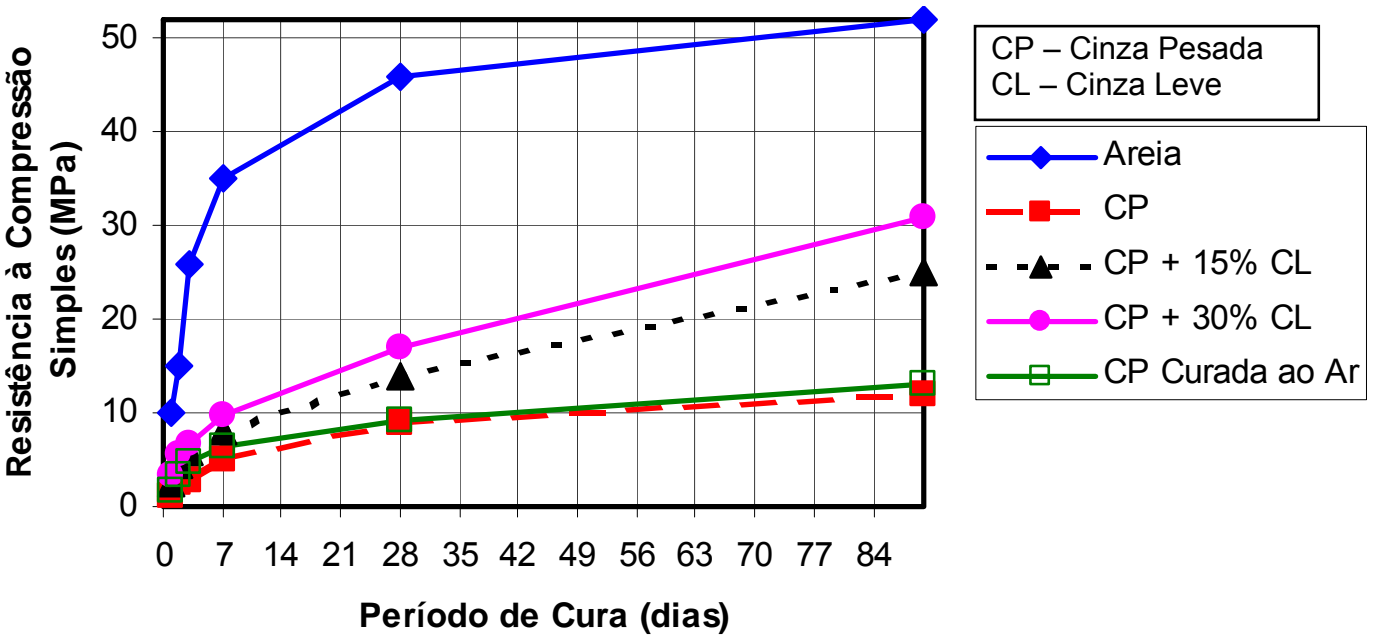

FIGURA 2.20 - Resistência à compressão simples das argamassas de cimento-areia e cimento-cinzas (adaptado de PIAZZA e RUI, 1999).

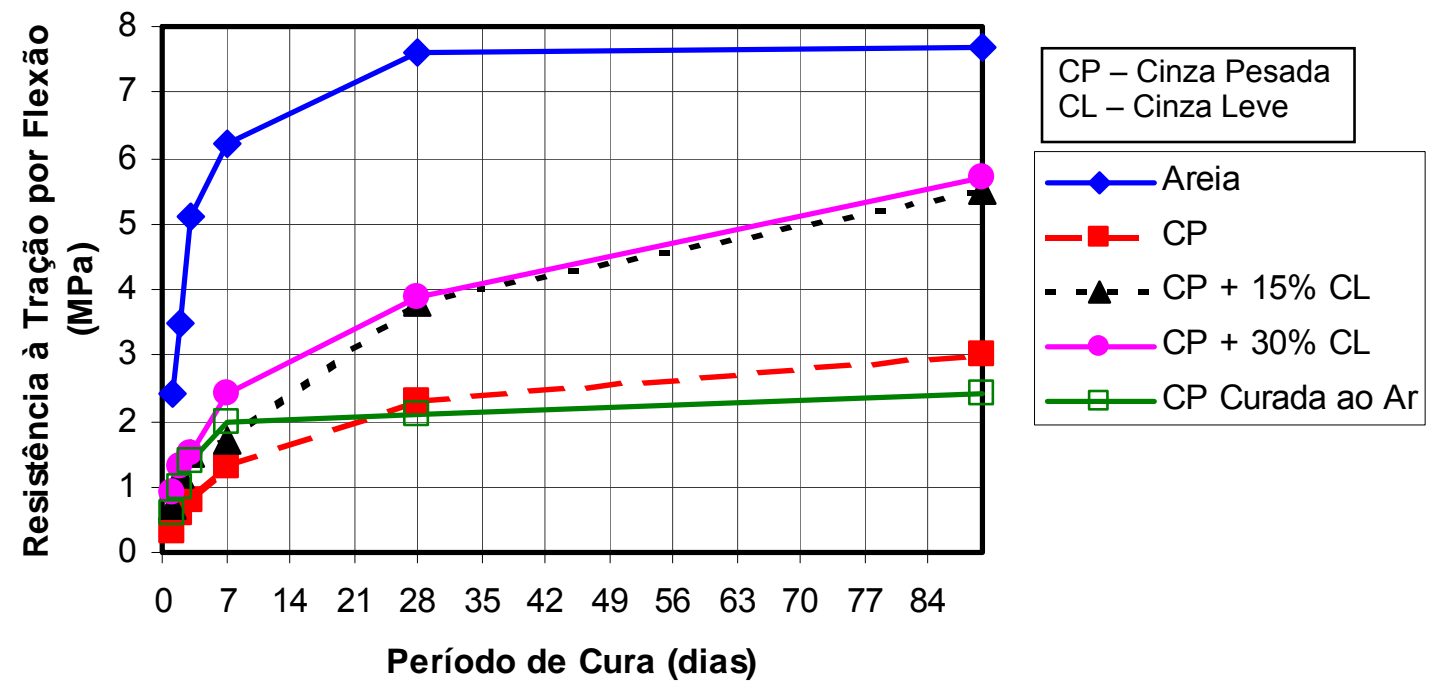

FIGURA 2.21 - Resistência à tração por flexão das argamassas de cimento-areia e cimento-cinzas (adaptado de PIAZZA e RUI, 1999). 
A atividade pozolânica das cinzas pesadas ficou evidenciada no estudo de Piazza e Rui (1999), através do incremento, em torno de 100\%, na resistência à tração por flexão e à compressão de argamassas ensaiadas aos 28 dias de cura, quando comparadas às argamassas ensaiadas aos 7 dias (figura 2.20 e figura 2.21). Outro fato indicativo da ocorrência das reações pozolânicas, devido ao emprego das cinzas, é que enquanto as resistências das argamassas de cimento e areia tendem a se manterem constantes após 28 dias de cura, as argamassas de cimento e cinzas apresentam ainda um aumento significativo e contínuo das resistências ao longo do tempo de cura.

A substituição de parte da cinza pesada pela leve elevou as resistências à compressão e à tração por flexão das argamassas (figura 2.21). Segundo os autores responsáveis pelo estudo, esse incremento ocorreu pelo fato de que as cinzas leves proporcionam uma menor demanda de água de amassamento e apresentam maior atividade pozolânica do que as cinzas pesadas. Além disso, a incorporação de cinza leve à cinza pesada proporciona um melhor preenchimento dos espaços vazios entre as partículas de cinza pesada por causa da menor dimensão das partículas de cinza leve.

Apesar de as argamassas de cimento e cinzas terem apresentado valores de resistência mecânica inferiores aos das argamassas de cimento e areia, Piazza e Rui (1999) afirmaram que os resultados obtidos indicam que as cinzas pesadas têm apresentado potencial significativo para substituir as areias quartzosas na fabricação de argamassas.

\subsection{4 - Cinza Pesada e Cal Hidratada em Tijolos Prensados}

Chies et al. (1998) desenvolveram um estudo que avaliou o comportamento mecânico dos tijolos através da resistência à compressão simples, visando o aproveitamento da cinza pesada estabilizada com cal hidratada na fabricação de tijolos prensados. As cinzas utilizadas naquele estudo eram provenientes das usinas termelétricas do sul do Brasil: Candiota 
(RS), Charqueadas (RS) e Capivari de Baixo (SC) e das centrais de vapor da RIOCELL (RS) e da COPESUL (RS).

A estabilização de cinzas com cal hidratada é geralmente similar à estabilização com cimento. Na estabilização com cimento, as cinzas têm a função quase que exclusiva de um agregado. Já na estabilização com cal, além de incorporar-se como agregados, as cinzas atuam também como elementos responsáveis pela formação de novos compostos cimentantes (CHIES et al., 1998).

A cal hidratada age sobre a cinza pesada explorando as propriedades pozolânicas dos resíduos sílico-aluminosos, melhorando a resistência, a estabilidade, a durabilidade e diminuindo a permeabilidade. Contudo, para que ocorram as reações pozolânicas, é necessário que exista quantidade de água suficiente para que elas se desenvolvam por completo. Além disso, essas reações ocorrem ao longo do tempo, sendo necessário, portanto, providenciar um período de cura adequado.

Na pesquisa de Chies et al. (1998), foram avaliadas várias umidades de moldagem: $15 \%$, 20\% e 25\%. Entretanto, os tijolos moldados com umidade de $15 \%$ apresentaram resistências menores do que os moldados com $20 \%$ de umidade, caracterizando a falta de água para a ocorrência completa da reação pozolânica. Para os tijolos moldados com $25 \%$ de umidade, ocorreram trincas, evidenciando o excesso de água. O teor de umidade de $20 \%$ foi o que melhor satisfez as condições para obtenção de tijolos de maior resistência e melhor aspecto físico.

Os tijolos foram moldados com uma mistura de 10\% de cal e $90 \%$ de cinza pesada, com $22 \mathrm{~cm}$ de largura, $10,5 \mathrm{~cm}$ de altura e $5 \mathrm{~cm}$ de espessura, sendo prensados mediante a aplicação de uma carga de 30t. Esses tijolos foram submetidos a dois processos de cura diferentes: (a) o primeiro consistiu na manutenção dos tijolos em sacos plásticos para a preservação de umidade à temperatura ambiente e em períodos de cura de 7, 14 e 28 dias. (b) no outro processo, os tijolos foram tratados hidrostaticamente em autoclave, onde foi 
adotada uma pressão/temperatura de vapor de água de $980,66 \mathrm{KPa} / 180^{\circ} \mathrm{C}$, com um tempo de permanência no processo de cura de 2 horas. O processo de cura em autoclave foi adotado pelos pesquisadores com a finalidade de acelerar as reações pozolânicas entre a cinza e a cal hidratada, fazendo com que surgissem novos grupos de silicatos de cálcio, que proporcionariam maiores ganhos de resistência.

Na tabela 2.12, é possível observar que a resistência à compressão simples dos tijolos estudados por Chies et al. (1998) aumentou com o aumento do tempo de cura para todas as cinzas pesadas estudadas, sendo que a máxima resistência obtida foi para os tijolos curados em autoclave. Os valores alcançados aos 28 dias de cura e na cura em autoclave excederam com folga as exigências vigentes para os tijolos cerâmicos e de solo-cimento estabelecidas pela ABNT, evidenciando, dessa forma, o potencial do emprego da cinza pesada na fabricação de tijolos para a construção civil.

TABELA 2.12 - Resistência à compressão simples dos tijolos com 10\% de cal e $90 \%$ de cinza pesada (CHIES et al., 1998).

\begin{tabular}{|c|c|c|c|c|}
\hline \multirow{2}{*}{$\begin{array}{c}\text { Procedência das } \\
\text { Cinzas Pesadas }\end{array}$} & \multicolumn{4}{|c|}{ Resistência à Compressão Simples (MPa) } \\
\cline { 2 - 5 } & \multicolumn{3}{|c|}{ Saco Plástico de Cura } \\
\cline { 2 - 5 } & 7 dias & 14 dias & 28 dias & \\
\cline { 2 - 5 } & 0,3 & 1,0 & 2,4 & 7,4 \\
\hline Candiota & 1,4 & 2,1 & 3,2 & 4,8 \\
\hline Charqueadas & 1,4 & 3,9 & 5,9 & 9,4 \\
\hline Copesul & 2,6 & 2,9 & 3,4 & 7,6 \\
\hline Riocell & 1,3 & 2,2 & 5,5 & 9,2 \\
\hline Capivari de Baixo & & &
\end{tabular}

\section{6 - CAL NA ESTABILIZAÇÃO DE SOLOS}

Assim como a cinza vulcânica, a cal é usada na construção civil há mais de 2.000 anos e credita-se aos romanos as primeiras aplicações desse material na construção rodoviária. A cinza vulcânica ou pozolana, material disponível e encontrado com freqüência naquela época e naquela região, era misturada à 
cal com o propósito de se obter uma pasta cimentante com melhores propriedades mecânicas.

A pozolana, segundo Heath e Brandenburg (1953) ${ }^{4}$ apud Lima (1981), por si só apresenta reduzida ou nenhuma capacidade de cimentação e pode ser definida como um material silicoso que reage com a cal e a água para formar compostos cimentícios capazes de aglutinarem as partículas do solo.

A cal reage com solos de granulometria média a fina para produzir redução da plasticidade, aumento da trabalhabilidade, redução da expansão e aumento da resistência mecânica. Os solos mais reativos à cal incluem os cascalhos argilosos, as argilas siltosas $\mathrm{e}$ as argilas. Todos os solos classificados pelo HRB como A-5, A-6 e A-7 e alguns classificados como A-2-6 e A-2-7 são mais propícios à estabilização com cal. Para o sistema unificado, os solos mais indicados à estabilização com cal são os solos $\mathrm{CH}, \mathrm{CL}, \mathrm{MH}, \mathrm{CL}$ MH, SC, SM, GC e GM (LIMA, 1981). Alguns autores não recomendam a estabilização de solos orgânicos (THOMPSON, 1966; INGLES e METCALF, 1973).

\subsection{1 - Reações Solo-Cal}

A adição de cal a um solo e na presença de água desencadeia uma série de reações. A troca catiônica e a floculação causam uma melhora imediata na plasticidade, trabalhabilidade, na resistência não curada e nas propriedades mecânicas (tensão x deformação).

A floculação (aglomeração das partículas) produz uma aparente modificação na textura do material com partículas de argila que se aderem à superfície dos agregados. Esse fenômeno pode ser atribuído ao aumento da concentração de eletrólitos nos poros e da adsorção de cálcio à superfície das partículas (TRB, 1987).

\footnotetext{
${ }^{4}$ HEATH, J. C. O.; BRANDENBURG, N. R. (1953). Pozzolanic properties of several Oregon. Corvallis, Oregon State System of Higher Educative, Oregon State College. Bulletin n. 34, 35 p.
} 
Nas misturas solo-cal geralmente ocorrem reações pozolânicas, formando vários agentes cimentantes que aumentam a resistência e a durabilidade das misturas compactadas. Essas reações pozolânicas, segundo TRB (1987), dependem, sobretudo, da temperatura e do tempo de cura. A resistência curada se desenvolve gradualmente ao longo do tempo e pode levar anos para se completar.

Os minerais do solo que reagem com a cal para produzir compostos com características de cimentação são conhecidos como pozolanas. Quando o solo não apresenta esses minerais em quantidade suficiente, outros materiais pozolânicos, tais como as cinzas volantes, ajudam a produzir a desejada reação com a cal (LIMA, 1981).

A cal, a água, a sílica e a alumina reagem formando componentes cimentantes. Possíveis fontes de sílica e alumina em solos incluem os minerais de argila, quartzo, feldspato, micas e outros silicatos ou alumino-silicatos similares, na forma cristalina ou amorfa na natureza.

A reatividade dos solos à cal é influenciada principalmente pelo $\mathrm{pH}$, teor de carbono orgânico, drenagem natural, presença de quantidades excessivas de sódio, mineralogia da fração argila, presença de carbonatos, ferro livre e relações sílica-sesquióxido e sílica-alumínio do solo natural (HARTY, 1971).

Quando uma quantidade suficiente de cal é adicionada ao solo, o pH da mistura solo-cal aumenta até alcançar o valor aproximado de 12,4, que aumenta significativamente a solubilidade da sílica. Segundo Chauvel e Nóbrega (1980), a dissolução parcial dos constituintes mineralógicos do solo, pela elevação do $\mathrm{pH}$ devido à adição da cal, pode ser seguida da formação de novos silicatos e aluminatos, estáveis nas condições de meio alcalino, e que estes minerais apresentam-se na forma de produtos cristalizados que se associam, constituindo grânulos capazes de conferir ao material uma determinada resistência mecânica. 
Alto valor de $\mathrm{pH}$ produz sílica a partir da dissolvição dos minerais de argila e a combinação com cálcio forma silicato de cálcio. Essa reação continuará acontecendo enquanto existir $\mathrm{Ca}(\mathrm{OH})_{2}$ e sílica disponível no solo (EADES, 19625 ; apud TRB, 1987).

\subsection{2 - Propriedades das Misturas Solo-Cal}

De uma forma generalizada, todos os solos exibem uma melhora na sua plasticidade e trabalhabilidade quando misturados com cal. No entanto, nem todos os solos apresentam melhora nas propriedades de fadiga, resistência e no comportamento tensão deformação (TRB, 1987). As propriedades das misturas solo-cal dependem de muitas variáveis como: tipo de solo, tipo de cal, porcentagem de cal, condições de cura incluindo tempo, temperatura e umidade. O efeito produzido por uma dada mudança em uma dada variável é dependente do nível de mudança das outras variáveis.

\subsubsection{1 - Características de compactação}

Quando compactada numa dada energia, a mistura solo-cal apresenta uma massa específica seca máxima menor do que a apresentada pelo solo natural, continuando a diminuir com o aumento do teor de cal adicionado. Já o teor de umidade ótimo aumenta com o aumento no teor de cal.

No estudo desenvolvido por Correa (1989), onde foram adicionados três teores de cal $(0,3$ e $6 \%)$ a um latossolo roxo fortemente argiloso, a massa específica seca máxima foi menor em relação ao solo natural para qualquer energia de compactação. Contudo, para 44 golpes, a diferença máxima entre as massas específicas do solo-cal ( $3 \%$ de cal em peso seco) e o solo natural não foi significativa.

\footnotetext{
${ }^{5}$ EADES, J. S. (1962). Reactions of $\mathrm{Ca}(\mathrm{OH})_{2}$ with clay minerals in soil stabilization. PhD thesis. Geology Department, University of Illinois.
} 


\subsubsection{2 - Resistência à compressão simples}

A resistência de solos tratados com cal pode ser avaliada de muitas maneiras, sendo mais comum a utilização de ensaios de compressão simples. Os ensaios de CBR, apesar de utilizados nesta avaliação, não são recomendados para este fim (TRB, 1987).

Uma diferenciação deve ser feita com respeito à cura. Um ganho imediato de resistência ocorre com a adição de cal, resultado das reações imediatas: troca catiônica, floculação - aglomeração. O ganho de resistência a longo prazo é regido, principalmente, pelas reações pozolânicas. Portanto, é necessário dividir a avaliação da resistência em: condição com cura e condição sem cura.

O efeito imediato benéfico da adição de cal é adequado à construção de acessos temporários que possibilitem o tráfego de veículos onde há ocorrência de solos moles, altamente plásticos ou que não ofereçam suporte satisfatório. O efeito imediato sobre a resistência do solo-cal pode ser avaliado através do ensaio de CBR e do ensaio de compressão simples. Em alguns casos, o ganho de resistência imediato pode ser maior que $100 \%$.

A resistência à compressão simples dos solos compactados na massa específica seca máxima e no teor de umidade ótimo, submetidos ao processo de cura, pode variar de $172 \mathrm{KPa}$ a $2068 \mathrm{KPa}$, dependendo da natureza do solo (TRB, 1987). Solos com cal do estado americano de Illinois apresentam uma resistência à compressão simples aos 28 dias de cura de mais de $670 \mathrm{KPa}$. Estendendo o período de cura para 56 dias, o ganho de resistência foi ainda maior, $4309 \mathrm{KPa}$. Prolongando o período de cura para 75 dias, de uma mistura com $5 \%$ de cal, a resistência média à compressão simples obtida foi de 10.893 KPa (TRB, 1987).

A diferença entre a resistência à compressão simples de um solo natural e do mesmo solo tratado com cal é usada como indicação do grau de reatividade do solo à cal. Ganhos substanciais de resistência indicam que o 
solo é reativo e que provavelmente pode ser estabilizado, produzindo um material de pavimentação de qualidade.

Lima (1981) realizou ensaios de compressão simples com teores de 3, 5, 7, 10 e $12 \%$ de cal misturados a oito solos do estado de São Paulo. Os corpos de prova foram moldados no equipamento de compactação de mini-CBR no teor de umidade ótimo e na massa específica seca máxima com $5 \mathrm{~cm}$ de diâmetro e $5 \mathrm{~cm}$ de altura. Os resultados indicaram uma queda de resistência para misturas com 5 e $7 \%$ de cal.

Os resultados de compressão simples obtidos por Lima (1981) para teores de cal de 3\% foram, em média, 2,41 vezes maiores do que a resistência apresentada pelos solos naturais. A reatividade dos solos à cal variou entre $196 \mathrm{KPa}$ (solo saprolítico de argilito) e $1404 \mathrm{KPa}$ (latossolo vermelho escuro fase arenosa). Dos oito solos estudados, apenas dois não apresentaram ganho suficiente de resistência à compressão simples para serem considerados reativos à adição de $3 \%$ de cal.

\subsubsection{3 - Resistência ao cisalhamento}

Os ensaios triaxiais têm sido empregados para simular parcialmente as condições de campo as quais os pavimentos são submetidos. O principal efeito da adição de cal a um solo reativo é o aumento no intercepto coesivo, com um pequeno aumento no ângulo de atrito interno (TRB, 1987).

Para solos típicos de Illinois, as misturas solo-cal apresentaram ângulo de atrito interno entre 25 e $35^{\circ}$, enquanto que o intercepto coesivo das misturas foi substancialmente aumentado quando comparado com a coesão do solo natural e continua a aumentar com o aumento na pressão de confinamento (TRB, 1981). 


\subsubsection{4 - Módulo de elasticidade}

O estudo das propriedades de tensão-deformação de um solo tratado com cal é essencial para a análise do comportamento mecânico da estrutura de um pavimento que possua em uma de suas camadas esse tipo de mistura.

O módulo de elasticidade está relacionado com a rigidez do material e é definido como a relação entre a variação de tensão e a respectiva variação na deformação, para um dado incremento de tensão. Para os materiais que apresentam uma relação tensão-deformação linear, o módulo é uma constante representada pela inclinação da "curva" tensão x deformação. Contudo, para materiais não perfeitamente elásticos, não é possível definir um valor para o módulo de elasticidade. Deste modo, Thompson (1967) ${ }^{6}$ apud Lima (1981), sugere para solos naturais e para misturas solo-cal não curadas o uso do módulo secante, que é definido como a inclinação de uma linha reta que passa pela origem e algum ponto arbitrário da curva tensão x deformação.

No estudo desenvolvido por Thompson (1967) apud Lima (1981), o módulo secante ficou definido a $75 \%$ da tensão desvio máxima com tensão confinante de $33,80 \mathrm{KPa}$. A figura 2.22 mostra o típico efeito da adição de cal a um solo no comportamento tensão deformação.

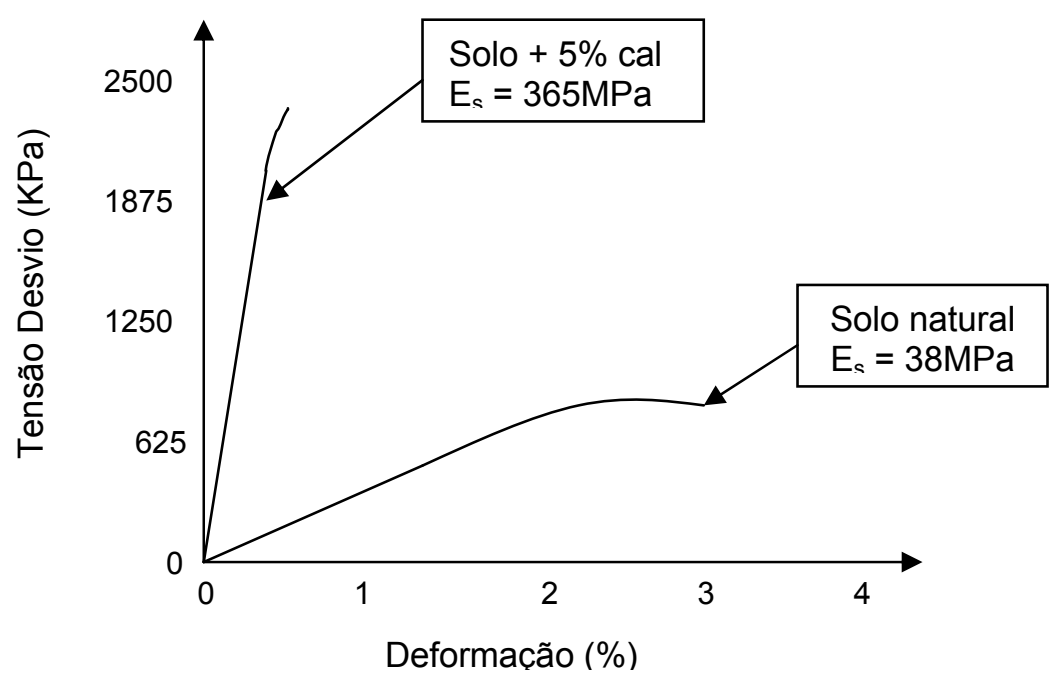

FIGURA 2.22 - Exemplo de comportamento tensão deformação do solo natural e do solo tratado com cal (TRB, 1987).

${ }^{6}$ THOMPSON, M. R. (1967). Engineering properties of lime-soil mixtures. ASTM, paper n. 78, $66 p$. 
Como pode ser observado no exemplo da figura 2.22, a adição de cal ao solo natural provoca o aumento da tensão de ruptura e a diminuição das deformações, ou seja, proporciona estabilidade ao solo com aumento elevado no módulo secante $\left(E_{s}\right)$.

No estudo elaborado por Neubauer e Thompson (1972), com relação a estabilização de quatro solos coesivos com cal, o módulo secante das misturas solo-cal não curadas variou de $12,26 \mathrm{MPa}$ a $57,86 \mathrm{MPa}$, sendo que os solos naturais apresentaram módulo secante entre 1,2MPa e 4,90MPa.

Para misturas solo-cal curadas, Thompson (1967) apud Lima (1981) sugere a adoção do módulo tangente inicial para o estudo da deformabilidade das misturas que apresentem resistência elevada (solos reativos).

Através de ensaios triaxiais, Thompson (1967) apud Lima (1981) encontrou para misturas solo-cal curadas módulo tangente inicial entre 189Mpa a 1.082MPa, enquanto que o módulo tangente inicial dos solos naturais variou entre 28MPa e 35MPa.

O módulo tangente inicial $\left(E_{0}\right)$ para uma tensão confinante de $103 \mathrm{KPa}$ pode ser estimado a partir da resistência à compressão não confinada para as misturas de solo cal curadas segundo a expressão 2.1 (THOMPSON, 1966):

$$
E_{0}=1.480+0.126 q u
$$

Onde:

$\mathrm{E}_{0}=$ Módulo tangente inicial (MPa);

qu $=$ resistência à compressão não confinada $(\mathrm{KPa})$.

\subsection{3 - Métodos para Determinação dos Teores de Cal}

Os métodos para determinação dos teores de cal nas misturas com solo podem ser divididos em duas categorias. A primeira é referente a situações 
onde o principal objetivo da estabilização é a redução do índice de plasticidade, melhora da trabalhabilidade e aumento imediato da resistência. A segunda categoria está relacionada com a melhora da resistência devido as reações pozolânicas entre o solo e a cal, ou seja, se uma mistura de solo-cal vai ser utilizada na construção de sub-base ou base de um pavimento, ela deverá apresentar resistência e durabilidade mínimas para atender as condições que serão exigidas.

Deste modo, a maior parte dos métodos especifica a resistência mínima requerida para uma mistura de solo-cal, sendo que o teor de cal adotado é aquele que proporciona a maior resistência para uma dada condição de cura. $\mathrm{O}$ método para determinação do teor de cal do estado americano de Illinois considera as duas categorias apresentadas anteriormente (TRB, 1987):

a) Modificação do Subleito: baseia-se no efeito da cal no índice de plasticidade do solo, podendo ser empregado opcionalmente o ensaio de CBR. Determina-se o limite de liquidez, limite de plasticidade e o índice de plasticidade (IP) do solo tratado com vários teores de cal. Antes da realização dos ensaios, a mistura solta de solo-cal é curada por uma hora e prepara-se um gráfico de índice de plasticidade versus teores de cal. O teor de cal de projeto será aquele para o qual posteriores adições de cal não proporcionem reduções significativas no índice de plasticidade. Dependendo da finalidade da estabilização, podese utilizar o ensaio de CBR para medida da estabilidade e expansão da mistura sol-cal.

b) Solo-cal em Camadas de Base e Sub-base: para este objetivo, o projeto da mistura baseia-se na resistência à compressão simples. São moldados corpos de prova com $5,10 \mathrm{~cm}$ de diâmetro e $10,20 \mathrm{~cm}$ de altura, no teor de umidade ótimo e na massa específica seca máxima do solo natural e do solo com vários teores de cal. Esses corpos de prova são curados por $48 \mathrm{~h}$ a uma temperatura de $48,90^{\circ} \mathrm{C}$ antes de serem submetidos aos ensaios. Exige-se que a resistência à compressão simples da mistura, no teor de $3 \%$ de cal, apresente um ganho mínimo 
de $338 \mathrm{KPa}$ com relação à resistência apresentada pelo solo natural. $\mathrm{O}$ teor de cal de projeto será aquele para o qual adições posteriores não proporcionem ganhos significativos de resistência. A resistência mínima requerida para base é de $1010 \mathrm{KPa}$ e para sub-base é de $677 \mathrm{KPa}$.

Outros departamentos de estradas americanos (Louisiana e Texas) consideram que a resistência à compressão simples mínima dos corpos de prova de solo-cal de $15,20 \mathrm{~cm}$ de diâmetro e $20,30 \mathrm{~cm}$ de altura, moldados no teor ótimo de umidade e na massa específica seca máxima, deve ser de 677 $\mathrm{KPa}$ e de $338 \mathrm{KPa}$ para base e sub-base de pavimentos, respectivamente. Segundo o método proposto por Thompson (TRB, 1987), misturas de solo-cal que apresentem ganhos maiores que $338 \mathrm{KPa}$ em relação ao solo natural são adequadas à construção de bases e sub-bases, ou seja, considera o solo reativo à cal.

O método do Departamento de Estradas do South Dakota estabelece o teor de cal em função do ensaio de CBR e do $\mathrm{pH}$. O teor inicial de cal é determinado através do pH e o teor de projeto é avaliado em relação ao ganho de "resistência" no ensaio de CBR. Se o ganho após 96 horas de cura imersa em água for maior do que 3 a 4 vezes a obtida para o solo natural, então, a mistura solo-cal será considerada de qualidade e propícia ao uso como camada de pavimento.

\subsection{4 - Relação entre as Propriedades Naturais dos Solos e a Reatividade com a Cal}

A reatividade solo-cal pode ser atribuída a quantidade de sílica e alumina presentes no solo e capazes de reagir com a cal. Então, Thompson (1966) afirma que a reatividade é passível de correlacionar-se com os fatores responsáveis pela relativa abundância de fontes de sílica e alumina, bem como a outros que exerçam ação catalisadora ou de atraso na dissolução da sílica e alumina nestas fontes. 
Moore e Jones (1971) estudaram vinte e quatro solos do estado de Illinois e encontraram correlações lineares significativas entre a sílica e o ferro extraível e a reatividade. Já no estudo elaborado por Harty (1971), os valores totais de sílica, alumina e ferro não apresentaram correlações significativas para um grupo de solos podzólicos.

Contudo, para o grupo de solos latossólicos, as quantidades de sílica, alumina e ferro apresentaram correlações lineares significativas com a reatividade solo-cal. Carvalho e Cabrera (1979) consideram que a reatividade dos solos vermelhos tropicais à cal apresenta correlações lineares significativas com os valores de sílica e alumina.

Com o objetivo de elucidar quais as propriedades naturais dos solos que influenciam significativamente a reatividade solo-cal, Lima (1981) testou existência de correlação linear simples das propriedades químicas e físicas para oito solos do estado de São Paulo.

No trabalho de Lima (1981), apenas a relação cálcio-magnésio e a porcentagem de sílica extraível, dentre todas as propriedades químicas, apresentaram correlação com a reatividade solo-cal. A relação cálcio-magnésio apresentou um coeficiente de correlação linear simples extremamente significativo, $r=0.93503$, enquanto que a porcentagem de sílica extraível mostrou uma correlação significativa $r=0,78508$.

As propriedades físicas que melhor se relacionam com a reatividade solo-cal, segundo Lima (1981), são o limite de liquidez, limite de plasticidade, índice de plasticidade e massa específica seca máxima. A porcentagem da fração argila, teor de umidade ótimo, massa específica dos sólidos não apresentaram correlação linear significativa com a reatividade solo-cal.

Entretanto, a granulometria e o índice de plasticidade exercem influência sobre a reatividade solo-cal, sendo que Harty (1971) recomenda a estabilização de solos que apresentem IP maior ou igual a 10\% e fração argila com mínimo de $10 \%$ a $15 \%$. 


\section{CAPÍTULO 3}

\section{MATERIAIS E MÉTODOS}

\section{1 - INTRODUÇÃO}

O estudo da viabilidade do aproveitamento da cinza pesada na construção de bases e sub-bases de pavimentos por meio da incorporação da cinza a solos é o foco principal da presente dissertação. A investigação foi feita através da avaliação dos efeitos resultantes da incorporação desse resíduo a solos, a partir da análise dos resultados dos ensaios de mini-CBR, resistências à compressão simples e à compressão diametral e CBR.

Para se conhecer e avaliar a capacidade de suporte das misturas de solo-cinza foi empregado o ensaio de mini-CBR, uma vez que este ensaio exige uma quantidade de material reduzida para a sua realização. Além disso, através deste ensaio foi determinado o teor de umidade ótimo, a massa específica seca máxima, a expansão e a contração de cada uma das misturas.

O ensaio de CBR foi realizado complementarmente por ser um ensaio corrente no meio rodoviário e por fornecer uma idéia da capacidade de suporte dos materiais a serem empregados na construção de bases e sub-bases de pavimentos e permitir o dimensionamento das camadas a partir de métodos usuais. Para a avaliação do comportamento mecânico das misturas de solo e cinza foram utilizados os ensaios de compressão simples e compressão diametral. 
Além disso, para avaliar o desenvolvimento das possíveis reações pozolânicas, os corpos-de-prova destinados à realização dos ensaios de compressão simples e compressão diametral, moldados com quatro proporções diferentes de solo e cinza pesada e solo-cinza-cal, foram submetidos a três períodos de cura diferentes em ambiente com condições de temperatura e umidade controladas.

Os teores de cinza foram determinados, preliminarmente, através dos ensaios de mini-CBR, tomando como base os teores estudados por Leandro (2002) para elaboração de misturas de um solo Podzólico Vermelho-Amarelo e a cinza pesada proveniente da mesma fonte da que foi estudada nesta dissertação. Dessa forma, após a definição das proporções de solo e cinza foram determinados os teores ótimos de umidade e as massas específicas secas máximas de cada uma das misturas através dos ensaios de mini-CBR, além de se obter o comportamento das misturas em termos de capacidade de suporte frente às adições de cinza pesada.

O teor de umidade ótimo e a massa específica seca máxima de cada mistura, obtidos preliminarmente, foram empregados para a moldagem dos corpos-de-prova que foram submetidos aos ensaios de compressão simples, compressão diametral e CBR.

No estudo experimental também foi verificada a necessidade da adição de cal hidratada às misturas de solo-cinza através de uma avaliação dos resultados preliminares dos ensaios de compressão simples sobre corpos-deprova curados em câmara úmida por 28 dias.

A figura 3.1 mostra o fluxograma das etapas adotadas no desenvolvimento do estudo. A seguir, são apresentadas as características dos solos, da cinza pesada e da cal hidratada utilizados neste trabalho e dos procedimentos empregados para a realização dos diversos ensaios envolvidos no desenvolvimento desta pesquisa. 


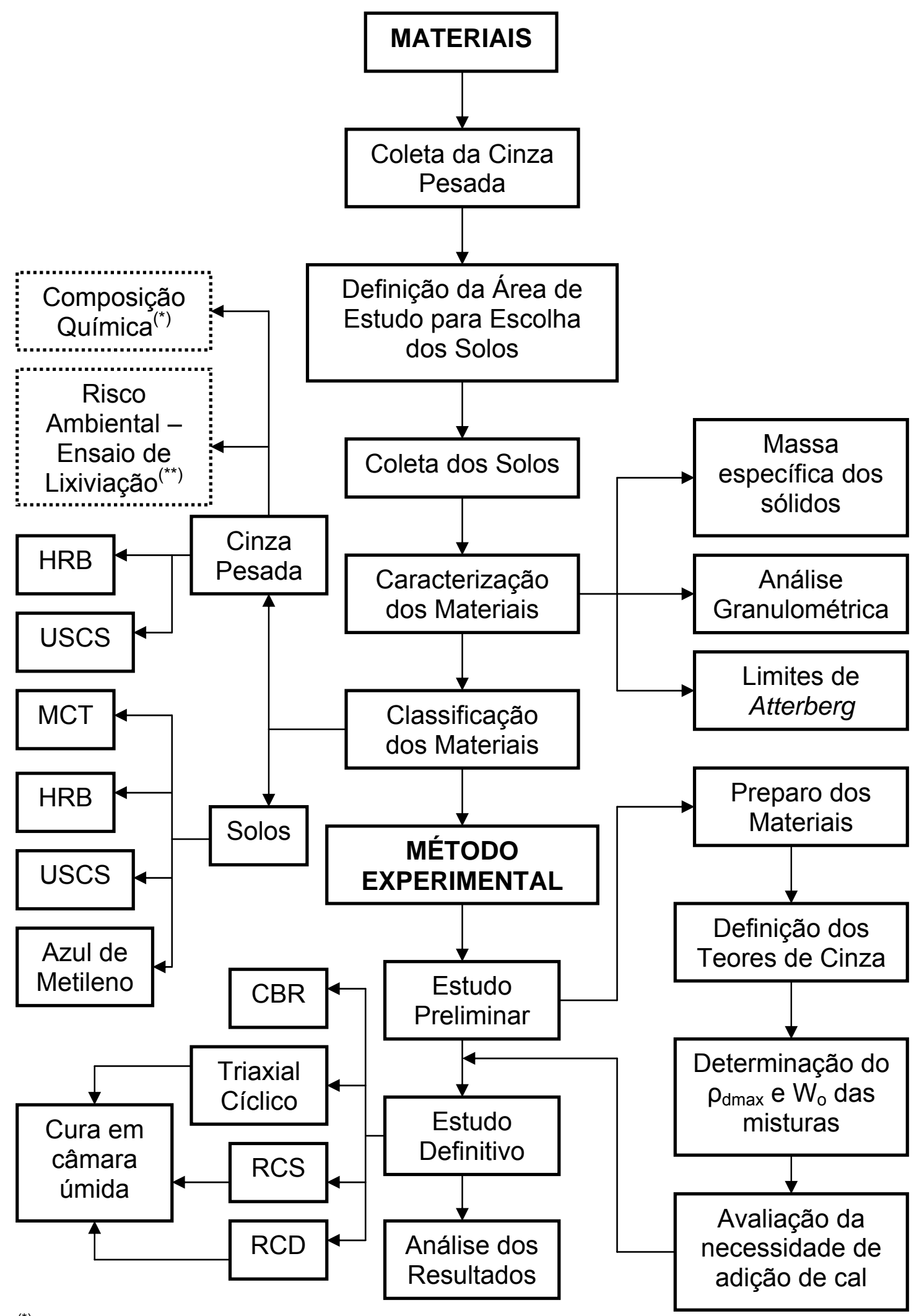

${ }^{(*)}$ Lovell et al. (1991), Nardi (1998) e Rocha et al. (1991).

${ }^{(*)}$ Lovell et al. (1991) e Deschamps (1997).

FIGURA 3.1 - Fluxograma das etapas do estudo experimental. 


\section{2 - MATERIAIS}

\subsection{1 - Cinza Pesada}

A cinza pesada empregada no programa experimental da presente dissertação foi coletada na bacia de sedimentação da Unidade C da Usina Termelétrica Jorge Lacerda, que está localizada no município de Capivari de Baixo, sul de Santa Catarina (figura 3.2) e que é composta por mais duas outras unidades: A e B.

A caracterização da cinza pesada foi feita por meio dos ensaios para determinação da massa específica dos sólidos, granulometria e dos limites de Atterberg.

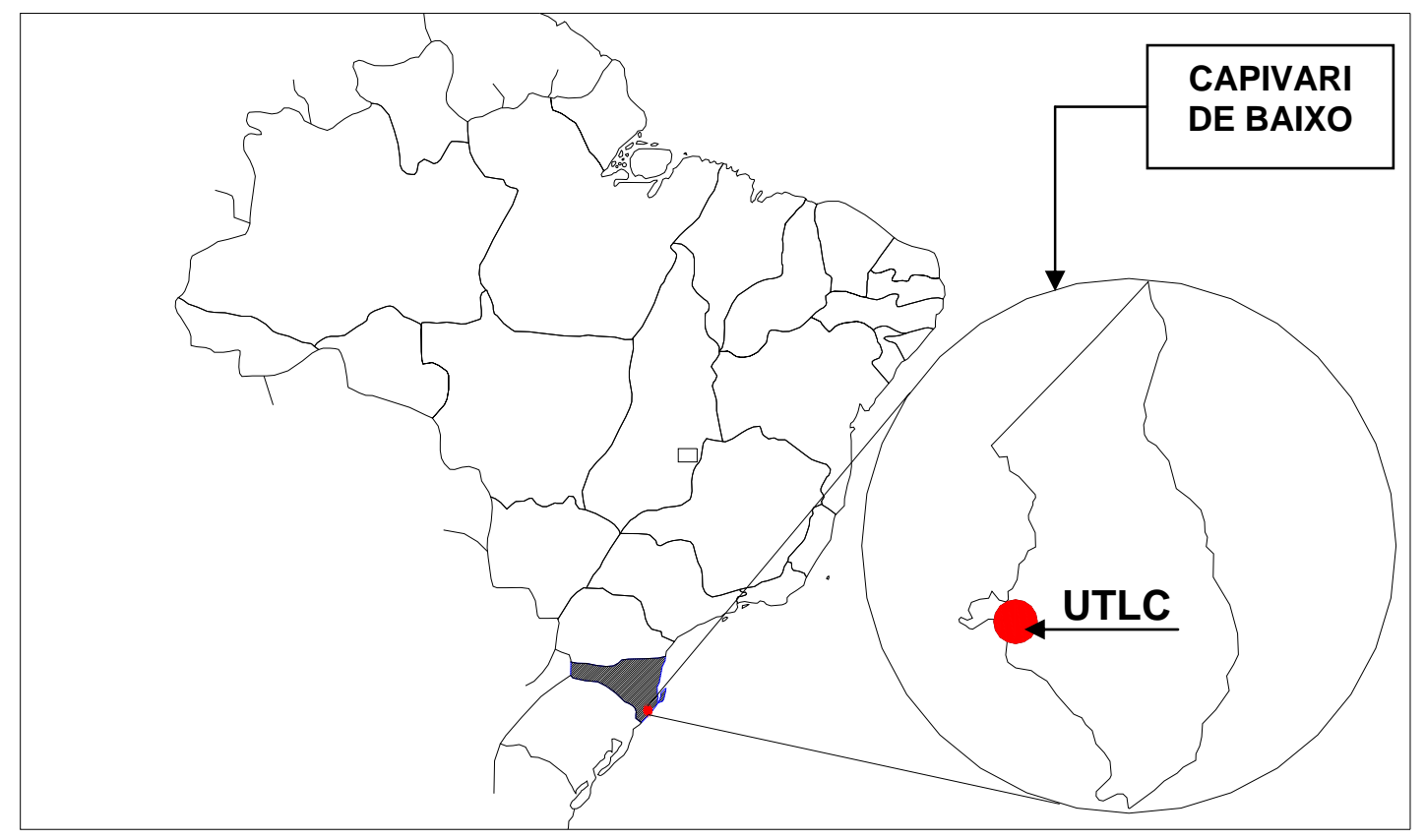

FIGURA 3.2 - Localização da Usina Termelétrica Jorge Lacerda.

\subsubsection{1 - Massa Específica dos Sólidos}

O ensaio para a determinação da massa específica dos sólidos foi realizado segundo a norma da ABNT NBR 6508 e o valor obtido foi de 
$1,979 \mathrm{~g} / \mathrm{cm}^{3}$, muito semelhante ao resultado encontrado por Leandro (2002) de $1,980 \mathrm{~g} / \mathrm{cm}^{3}$ e o encontrado por Rocha (2001) de $1,910 \mathrm{~g} / \mathrm{cm}^{3}$.

\subsubsection{2 - Granulometria}

A análise granulométrica foi realizada segundo o método de ensaio ABNT NBR 7181/84, obtendo-se, desta maneira, a distribuição granulométrica apresentada na figura 3.3. Esta figura também mostra a distribuição granulométrica obtida por Leandro (2002) para a cinza pesada proveniente da mesma fonte.

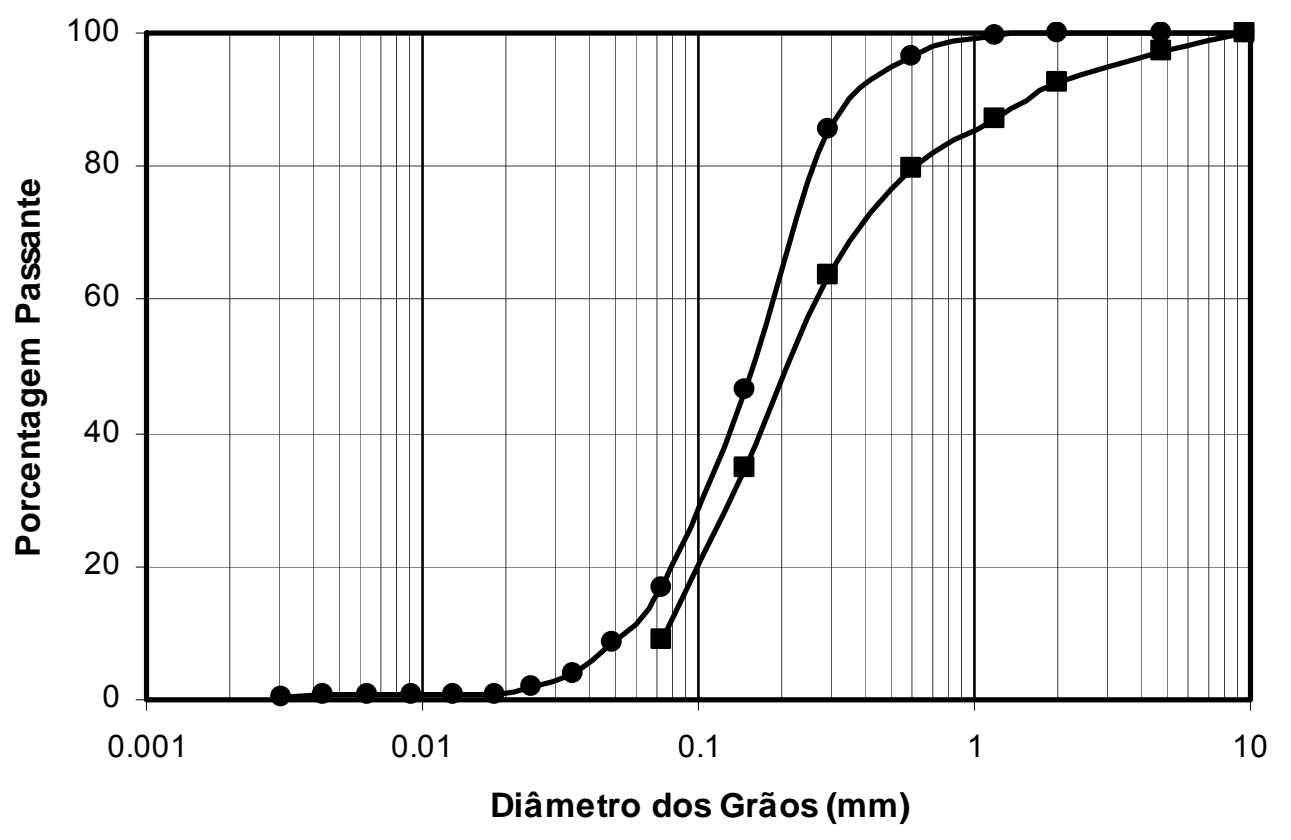

FIGURA 3.3 - Distribuição granulométrica da cinza pesada empregada no presente estudo e a obtida por Leandro (2002).

Segundo a distribuição granulométrica, a cinza pesada seria classificada como uma areia fina. Fazendo uma comparação entre as duas distribuições granulométricas, apresentadas na figura 3.3, percebe-se certa semelhança entre elas com respeito à forma da curva entre os grãos com dimensões maiores que $0,075 \mathrm{~mm}$ e menores que 0,200 $\mathrm{mm}$. Contudo, uma diferença razoável entre as duas distribuições é observada para os grãos maiores que $0,200 \mathrm{~mm}$. 


\subsubsection{3 - Limites de Atterberg}

O ensaio de limite de liquidez, segundo a norma da ABNT NBR 6459, foi considerado inexeqüível, uma vez que a cinza pesada não apresentou trabalhabilidade suficiente para a execução do ensaio de limite de plasticidade conforme especificado pela norma da ABNT NBR 7180, levando a classificar a cinza pesada como um material não plástico. Outros autores, como Usmen et al. (1983) e Majizadeh et al. (1979), também classificaram a cinza como um material não plástico.

\subsubsection{4 - Classificação}

O resultado da análise granulométrica e o caráter não plástico da cinza pesada possibilitaram classificar este resíduo segundo o método de classificação da HRB (Highway Research Board). Assim, se a cinza pesada fosse um solo, seria classificada como um solo pertencente ao grupo A-3. Já segundo o sistema de classificação USCS (Unified Soil Classification System), a cinza pesada seria classificada como um solo SM (areia siltosa).

A tentativa de classificar a cinza segundo a metodologia MCT de classificação de solos (NOGAMI e VILLIBOR, 1995) não foi possível. Durante a realização do ensaio de mini-MCV, verificou-se que, devido à baixa massa específica dos grãos de cinza pesada, a massa de $200 \mathrm{~g}$ (padronizada segundo o método DNER - ME 258/94) de cinza a ser colocada dentro do cilindro de ensaio proporcionaria um volume maior do que a capacidade do molde.

\subsection{2 - Solos}

A escolha dos solos a serem utilizados nesta pesquisa ficou restrita à área em torno da usina termelétrica na qual foi coletada a cinza. Dessa forma, delimitou-se a área de estudo em um círculo com aproximadamente $50 \mathrm{~km}$ de raio com centro a partir da usina térmica em questão. 
Com a definição da área de estudo e com o mapa pedológico da região foi possível distinguir os diferentes tipos de solos existentes e quais deles seriam adequados à pesquisa, descartando-se os solos encontrados em pequenas quantidades e aqueles cuja pedologia indicasse características inadequadas para uso em obras de pavimentação. Assim, dos solos encontrados em maior quantidade, optou-se pelos com classificação pedológica de Podzólico Vermelho-Amarelo (PV). As amostras foram coletadas em taludes rodoviários com alturas inferiores a 1,5m nos municípios de Treze de Maio (TM), Jaguaruna (JG) e Sangão (SG). As figuras 3.4 e 3.5 mostram a localização dos pontos de coleta na área de estudo e os perfis dos solos coletados, respectivamente.

Após a coleta, os solos foram destorroados, peneirados e secos ao ar para, então, serem homogeneizados e estocados em sacos plásticos devidamente identificados.

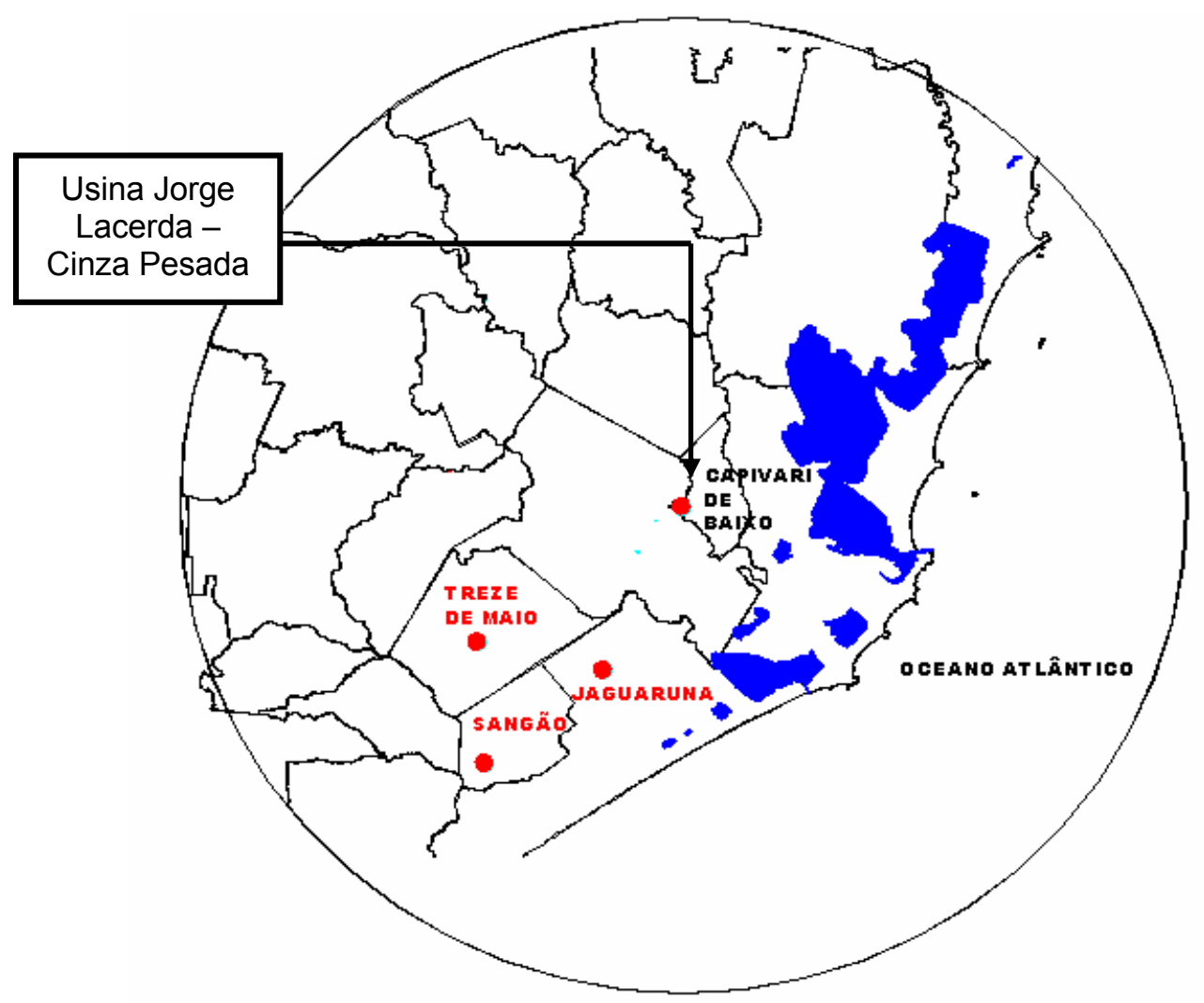

FIGURA 3.4 - Localização dos pontos de coleta das amostras de solo e de cinza pesada. 

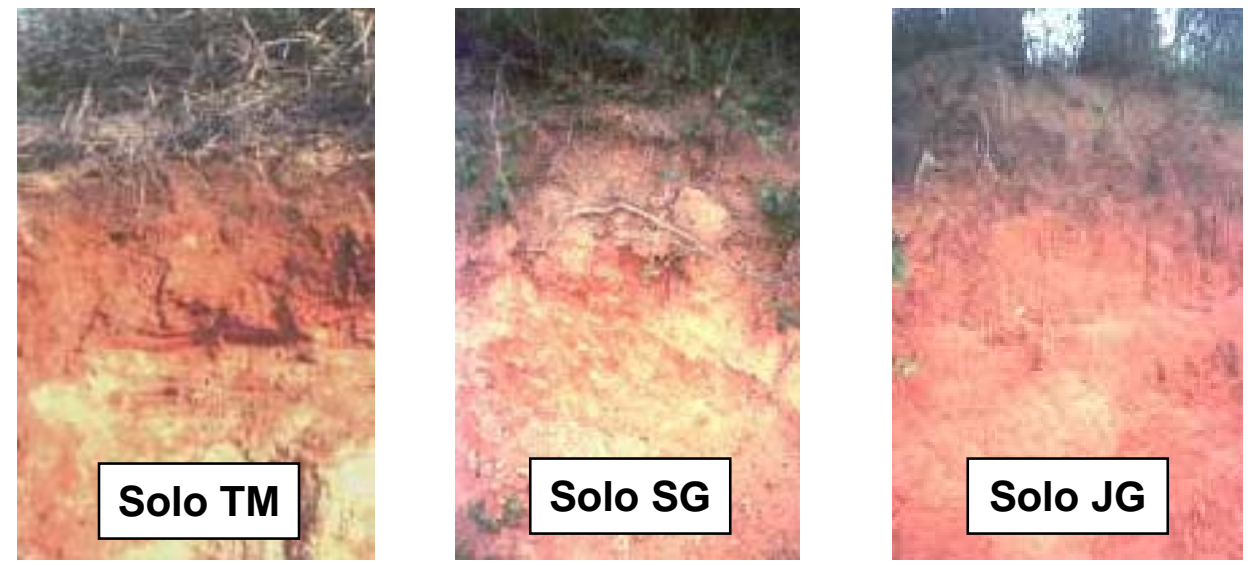

FIGURA 3.5 - Perfis dos solos provenientes de: Treze de Maio (TM), Sangão (SG) e Jaguaruna (JG).

\subsubsection{1 - Caracterização e Classificação dos Solos}

Os solos foram caracterizados por meio dos mesmos ensaios utilizados para a cinza pesada, conforme descrito no item 3.2.1; a seguir, são apresentados os resultados obtidos.

A tabela 3.1 apresenta os resultados obtidos dos ensaios de Limites de Atterberg e a massa específica dos sólidos para os três solos empregados na pesquisa. As massas específicas dos sólidos dos solos são maiores que a da cinza pesada. Isso já era esperado uma vez que a cinza pesada, conforme apresentado no capitulo 2, apresenta uma textura altamente porosa.

TABELA 3.1 - Resultados dos ensaios de massa específica dos sólidos e dos Limites de Atterberg para os solos estudados.

\begin{tabular}{|c|c|c|c|c|c|}
\hline $\begin{array}{c}\text { Procedência } \\
\text { do Solo }\end{array}$ & Nomenclatura & $\begin{array}{c}\text { Massa } \\
\text { específica } \\
\text { dos sólidos } \\
\left(\mathrm{g} / \mathrm{cm}^{3}\right)\end{array}$ & $\begin{array}{c}\text { Limite de } \\
\text { liquidez } \\
(\%)\end{array}$ & $\begin{array}{c}\text { Limite de } \\
\text { Plasticidade } \\
(\%)\end{array}$ & IP (\%) \\
\hline Jaguaruna & JG & 2,688 & 66,8 & 39,4 & 27.3 \\
\hline Treze de Maio & TM & 2,642 & 65,4 & 37,7 & 27.6 \\
\hline Sangão & SG & 2,632 & 51,3 & 32,2 & 19.0 \\
\hline
\end{tabular}

Quanto às distribuições granulométricas dos solos escolhidos para o desenvolvimento desta pesquisa, a tabela 3.2 apresenta as porcentagens 
constituintes de areia, silte e argila e a figura 3.6 mostra as curvas granulométricas.

TABELA 3.2 - Porcentagens de areia, silte e argila dos solos estudados.

\begin{tabular}{|c|c|c|c|c|}
\hline \multirow{2}{*}{ Solo } & \multicolumn{3}{|c|}{ Porcentagens (\%) } & $\begin{array}{c}\text { Porcentagem Passante na } \\
\text { peneira } \mathrm{n}^{\circ} 200(\%)\end{array}$ \\
\cline { 2 - 4 } & Areia & Silte & Argila & 66,0 \\
\hline Jaguaruna (JG) & 35 & 7 & 58 & 70,0 \\
\hline Treze de Maio (TM) & 32 & 30 & 38 & 56,5 \\
\hline Sangão (SG) & 44 & 26 & 30 & \multirow{2}{*}{ Sann } \\
\hline
\end{tabular}

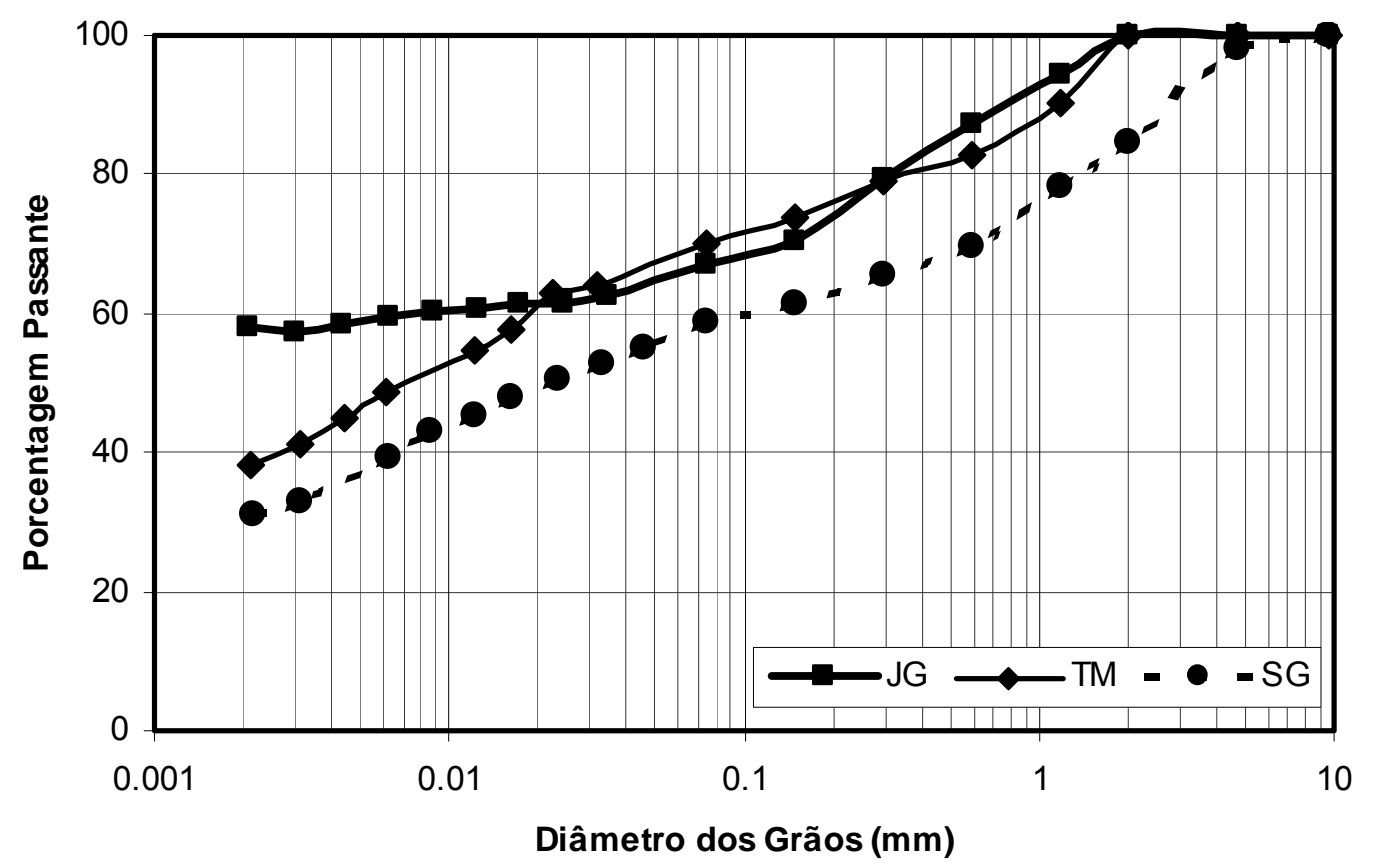

FIGURA 3.6 - Distribuição granulométrica dos solos coletados na área de estudo.

Na tabela 3.2, é possível observar que os solos JG e TM possuem uma distribuição argilo-arenosa, sendo que o segundo apresente maior quantidade de silte. Já o solo SG apresenta uma distribuição areno-argilosa. As porcentagens de areia dos solos JG e TM são semelhantes, bem como as porcentagens passantes na peneira $n^{\circ} 200$. O solo proveniente do município de TM foi o que apresentou maior quantidade passante nesta peneira enquanto que a menor quantidade passante na peneira $n^{\circ} 200$ foi observada para o solo SG. 
A forma das curvas da distribuição granulométrica dos solos também é semelhante. Na figura 3.6, verifica-se que estes materiais apresentaram distribuição aproximadamente contínua.

Segundo a metodologia MCT de classificação de solos, apenas o solo JG foi classificado como laterítico (LG', laterítico argiloso). Os outros dois solos foram classificados como não lateríticos. Segundo os valores dos coeficientes e' e c', os solos TM e SG pertencem ao grupo dos solos não lateríticos argilosos (NG'). Na realização do ensaio de mini-MCV para o solo de Sangão, o material retido na peneira $\mathrm{n}^{\circ} 10(2,00 \mathrm{~mm})$ foi desprezado. A figura 3.7 mostra a posição das amostras de solos no ábaco da classificação MCT.

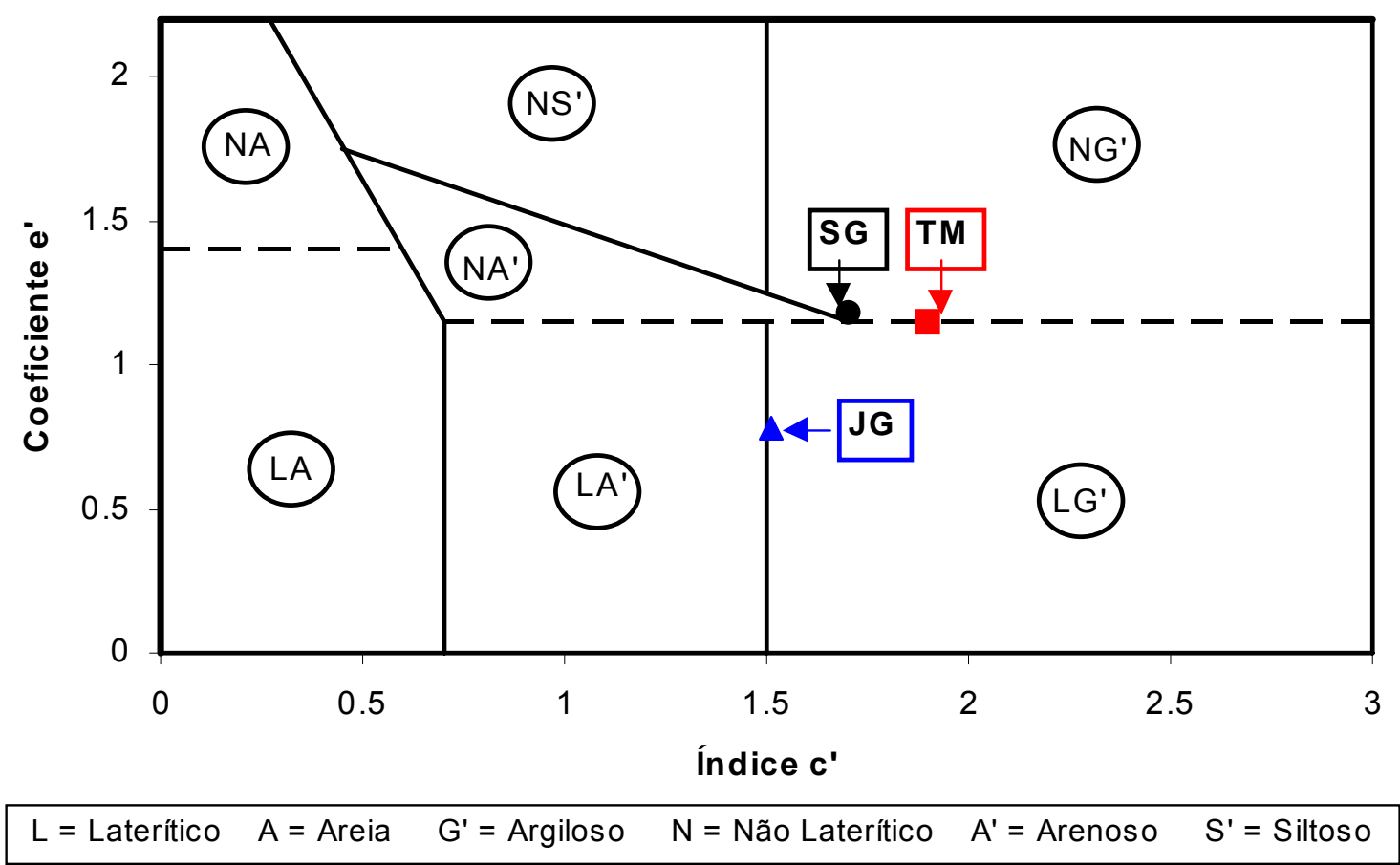

FIGURA 3.7 - Posição dos solos no ábaco de classificação MCT.

Para a caracterização da fração fina dos solos utilizou-se o método de adsorção de azul de metileno proposto por Fabbri (1994). Este método possibilita quantificar a atividade do conjunto de argilo-minerais presentes nos solos por meio da determinação do coeficiente de atividade (CA). O CA corresponde à média ponderada das atividades dos argilo-minerais existentes, proporcionalmente à sua atividade. A tabela 3.3 apresenta o grau de atividade dos argilo-minerais presentes nos solos e um resumo das classificações dos solos desta pesquisa segundo os métodos MCT, HRB e USCS. 
TABELA 3.3 - Classificação dos solos segundo os métodos MCT, HRB, USCS e atividade dos argilo-minerais em função do CA.

\begin{tabular}{|c|c|c|c|c|c|}
\hline \multirow[b]{2}{*}{ Solo } & \multicolumn{3}{|c|}{ Sistema de Classificação } & \multicolumn{2}{|c|}{$\begin{array}{l}\text { Classificação da fração } \\
\text { fina dos solos }\end{array}$} \\
\hline & MCT & HRB & USCS & $\mathrm{CA}^{*}$ & $\begin{array}{l}\text { Atividade dos } \\
\text { argilo-minerais }\end{array}$ \\
\hline Jaguaruna (JG) & $\mathrm{LG}^{\prime}$ & A-7-6 & $\mathrm{MH}$ & 14,20 & Ativo \\
\hline Treze de Maio (TM) & NG' & A-7-5 & $\mathrm{MH}$ & 14,48 & Ativo \\
\hline Sangão (SG) & NG' & A-7-6 & $\mathrm{MH}$ & 14,60 & Ativo \\
\hline
\end{tabular}

${ }^{*} \mathrm{CA}$ - Coeficiente de atividade dos argilo-minerais (FABBRI, 1994).

Conforme o apresentado na tabela 3.3, percebe-se que segundo o sistema de classificação MCT os solos TM e SG são considerados não lateríticos e apenas o solo JG é classificado como laterítico. Já segundo o sistema de classificação da HRB os solos JG e SG são classificados como A-76 enquanto o solo TM é classificado como um solo do grupo A-7-5. Os três solos apresentam a mesma classificação segundo o sistema unificado, $\mathrm{MH}$.

Os argilo-minerais presentes nos três solos foram classificados como ativos segundo o método de adsorção de azul de metileno, apresentando coeficiente de atividade entre 14,20 e 14,60.

\subsection{3 - Cal}

A cal empregada nas misturas com solo e cinza pesada é um produto comercial disponível na região de São Carlos. A cal é da marca Supercal, do tipo $\mathrm{CH}$-III e suas propriedades são as apresentadas na tabela 3.4.

TABELA 3.4 - Propriedades da cal cálcica, Supercal CH-III.

\begin{tabular}{|c|c|}
\hline Propriedades & Composição química \\
\hline Estrutura microcristalina: romboédrica & $\mathrm{Ca}(\mathrm{OH})_{2}: 98,5 \%$ \\
\hline Origem: sedimentar marinha & $\mathrm{MgO}: 3,5 \%$ máx. \\
\hline Massa específica dos sólidos: $2,700 \mathrm{~g} / \mathrm{cm}^{3}$ & $\mathrm{SiO}_{2}: 0,3 \%$ máx. \\
\hline Dureza Mohs: 3,00 & $\mathrm{R}_{2} \mathrm{O}_{3}: 1,5 \%$ máx. \\
\hline
\end{tabular}

Fonte: Ficha técnica do produto (CARBOMIL, 2003). 


\section{3 - MÉTODO EXPERIMENTAL}

O método experimental empregado na pesquisa foi dividido em duas etapas: estudo preliminar e estudo definitivo.

\subsection{1 - Estudo Preliminar}

$\mathrm{Na}$ etapa inicial foram definidas as proporções das misturas de solo e cinza pesada com base nos teores estudados por Leandro (2002) e nas capacidades de suporte determinadas através de ensaios de mini-CBR. Também foi avaliada, nesta fase, a necessidade da incorporação de cal às misturas de solo-cinza através dos ensaios (preliminares) de compressão simples.

\subsubsection{1 - Preparo dos Materiais}

Os solos, depois de coletados, foram destorroados e secos ao ar até atingirem a umidade higroscópica. Após este processo, foram submetidos ao peneiramento (peneira número 4) para, em seguida, serem homogeneizados e armazenados em sacos plásticos devidamente identificados para posterior utilização. A preparação da cinza pesada seguiu o mesmo processo, porém, o destorroamento do material não se fez necessário.

\subsubsection{2 - Determinação das Proporções de Solo, Cinza Pesada e Cal}

A definição dos teores de cinza empregados nas misturas com os solos, para a realização do estudo preliminar, foi baseada no trabalho realizado por Leandro (2002) que utilizou um solo Podzólico Vermelho-Amarelo e a cinza pesada da Usina Termelétrica Jorge Lacerda.

Os teores de cinza utilizados naquela pesquisa foram $0 \%, 25 \%, 35 \%$, $40 \%$ e $50 \%$. Os resultados indicaram um ganho no valor de CBR quase que linear até próximo ao teor de $35 \%$ de cinza pesada. Para os teores de $40 \%$ e 
$50 \%$, os valores de CBR diminuíram gradativamente. Dessa forma, o teor ótimo "teórico" de cinza, determinado naquela pesquisa, que proporcionaria o maior valor de $\mathrm{CBR}$, foi de $37 \%$ em peso.

Portanto, para o presente método experimental adotou-se os teores de 0\%, 25\%, 35\% e 45\% de cinza pesada na composição das misturas com solo para realização do estudo preliminar, no qual foram determinados, através dos ensaios de mini-CBR, o teor de umidade ótimo e a massa específica seca máxima das misturas. Esses resultados orientaram a moldagem dos corpos-deprova destinados à realização dos ensaios de compressão simples, compressão diametral e CBR.

Após a determinação das proporções de solo e cinza a serem empregadas no estudo definitivo, realizou-se um estudo prévio com estas proporções através de ensaios de compressão simples com corpos-de-prova curados em câmara úmida por 28 dias. Os resultados indicaram uma diminuição da resistência à compressão simples com o aumento no teor de cinza pesada adicionado às misturas, evidenciando, assim, a necessidade de estabilização com cal.

O teor de cal a ser incorporado às misturas com solo e solo-cinza foi arbitrado em $3 \%$ em peso seco em substituição a porcentagem de cinza pesada. Outros autores, como LIMA (1981) e CORREA (1989), empregaram este teor de cal para avaliar o efeito estabilizante deste material quando empregado em misturas com solos argilosos. A tabela 3.5 apresenta as proporções de solo, cinza e cal utilizadas em cada uma das misturas desta pesquisa.

A nomenclatura de cada uma das misturas é representada pelas iniciais maiúsculas do local onde as amostras de solos foram coletadas e, em seguida, a outra letra maiúscula indica a presença de cal ou não na mistura $(A-$ sem cal; B - com 3\% de cal). O par de números subscritos revela a porcentagem de cinza pesada presente na mistura. A figura 3.8 ilustra um exemplo de nomenclatura e seu significado. 
TABELA 3.5 - Proporções de solo, cinza pesada e cal empregadas em cada mistura para cada tipo de solo.

\begin{tabular}{|c|c|c|c|c|c|c|}
\hline & \multicolumn{3}{|c|}{ MISTURAS } & \multicolumn{3}{c|}{ Porcentagens (\%) } \\
\cline { 2 - 7 } & Jaguaruna & $\begin{array}{c}\text { Treze de } \\
\text { Maio }\end{array}$ & Sangão & Solo & $\begin{array}{c}\text { Cinza } \\
\text { Pesada }\end{array}$ & Cal \\
\hline \multirow{4}{*}{ : } & $\mathrm{JGA}_{00}$ & $\mathrm{TMA}_{00}$ & $\mathrm{SGA}_{00}$ & 100 & 0 & 0 \\
\cline { 2 - 7 } & $\mathrm{JGA}_{25}$ & $\mathrm{TMA}_{25}$ & $\mathrm{SGA}_{25}$ & 75 & 25 & 0 \\
\cline { 2 - 7 } & $\mathrm{JGA}_{35}$ & $\mathrm{TMA}_{35}$ & $\mathrm{SGA}_{35}$ & 65 & 35 & 0 \\
\cline { 2 - 7 } & $\mathrm{JGA}_{45}$ & $\mathrm{TMA}_{45}$ & $\mathrm{SGA}_{45}$ & 55 & 45 & 0 \\
\cline { 2 - 7 } & $\mathrm{JGB}_{00}$ & $\mathrm{TMB}_{00}$ & $\mathrm{SGB}_{00}$ & 97 & 0 & 3 \\
\cline { 2 - 7 } & $\mathrm{JGB}_{22}$ & $\mathrm{TMB}_{22}$ & $\mathrm{SGB}_{22}$ & 75 & 22 & 3 \\
\cline { 2 - 7 } & $\mathrm{JGB}_{32}$ & $\mathrm{TMB}_{32}$ & $\mathrm{SGB}_{32}$ & 65 & 32 & 3 \\
\cline { 2 - 7 } & $\mathrm{JGB}_{42}$ & $\mathrm{TMB}_{42}$ & $\mathrm{SGB}_{42}$ & 55 & 42 & 3 \\
\hline
\end{tabular}

Mistura do solo de Jaguaruna com $25 \%$ de cinza pesada e sem cal.

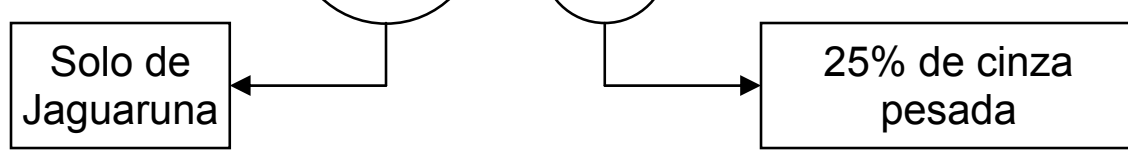

Sem cal pesada

FIGURA 3.8 - Exemplo de nomenclatura adotada para distinguir as misturas dos três solos com os vários teores de cinza e também com a cal.

\subsection{2 - Estudo Definitivo}

A preparação e moldagem dos corpos-de-prova para a realização do estudo definitivo foram feitas com base nos valores de teor de umidade ótimo e massa especifica seca máxima obtidos no estudo preliminar. Nessa etapa do trabalho foram realizados os seguintes ensaios:

\subsubsection{1 - Ensaios de Compressão Simples}

A moldagem dos corpos-de-prova destinados aos ensaios de compressão simples foi feita mediante a aplicação de compactação dinâmica em seis camadas iguais. Ao fim da compactação de cada uma das camadas foi 
executada uma escarificação na superfície proporcionando uma maior aderência entre as interfaces. Nesse processo utilizou-se um cilindro bipartido de bronze com 5,10 cm de diâmetro e 10,20 cm de altura. A norma do DNER ME - 180/94 serviu de base para a realização dos ensaios de compressão simples.

Para a realização dos ensaios de compressão simples, foram moldados três corpos-de-prova para cada um dos quatro teores de cinza empregados nas misturas com os solos, num subtotal de 12 corpos-de-prova. Considerando que foram empregados três períodos de cura (zero, 28 e 84 dias), teve-se, ao fim, 36 corpos-de-prova para cada tipo de solo. Para as misturas de solo-cinza-cal foram empregadas as mesmas quantidades de corpos-de-prova, 36 por tipo de solo.

Além da resistência à compressão simples das misturas de solo-cinza e solo-cinza-cal, também foi avaliada a deformabilidade dessas misturas através da determinação do módulo tangente inicial, $E_{0}$ (DUCAN e CHANG, 1970). Assim, a prensa de CBR do Laboratório de Estradas do Departamento de Transportes da EESC foi instrumentada de forma a se medir as cargas e os deslocamentos durante a aplicação do carregamento axial.

Ducan e Chang (1970) consideram a curva tensão x deformação como uma hipérbole representada pela seguinte equação:

$$
\frac{\varepsilon_{a}}{\sigma_{a}}=a+b \times \varepsilon_{a}
$$

onde:

$\varepsilon_{\mathrm{a}}$ - deformação axial $(\mathrm{mm} / \mathrm{mm})$;

$\sigma_{a}-$ tensão axial (kPa);

a e b-coeficientes de regressão. 
Assim, o módulo tangente inicial $\left(\mathrm{E}_{0}\right)$ é calculado pela expressão 3.2:

$$
E_{0}=\frac{1}{a}
$$

$O \mathrm{E}_{0}$ pode ser calculado graficamente a partir do coeficiente "a", como mostrado na figura 3.9. A determinação do coeficiente "a" é feita através da reta que melhor se ajusta aos pares de pontos referentes à deformação axial (eixo das abscissas) pela relação entre essa deformação e a tensão axial aplicada (eixo das ordenadas). Devido à imprecisão existente na determinação de deslocamentos muito pequenos, os pontos iniciais da curva tensão $x$ deformação devem ser descartados, assim como os pontos posteriores à ruptura do corpo-de-prova (PARENTE, 2002).

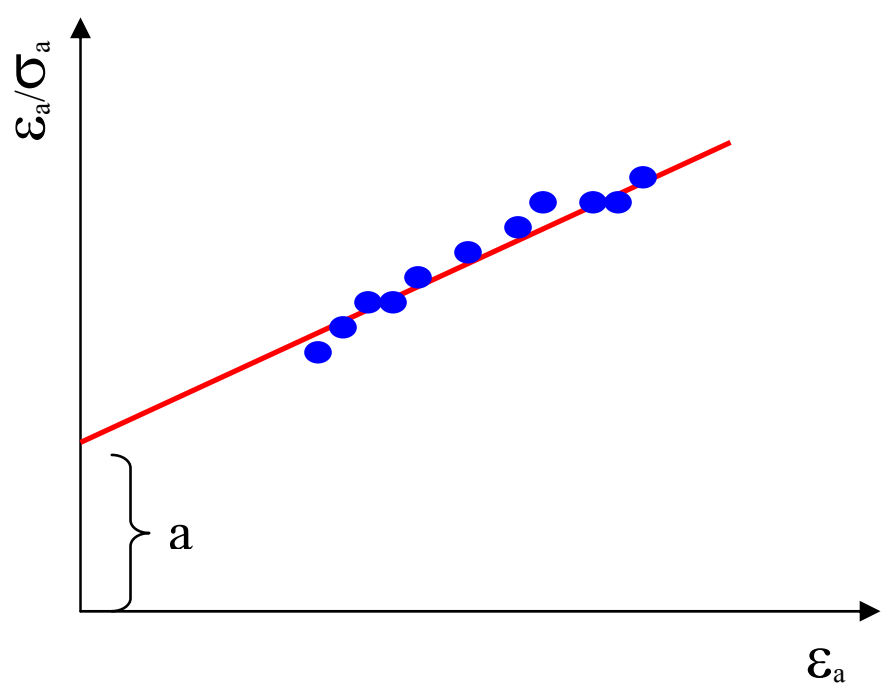

FIGURA 3.9 - Exemplo da estimativa de $E_{0}$ a partir da determinação do coeficiente "a" (adaptado de DUCAN e CHANG, 1970).

Nos casos em que não seja possível ajustar o comportamento tensão $x$ deformação a uma hipérbole, o módulo tangente inicial pode ser calculado graficamente fazendo-se passar uma tangente no inicio da curva tensão $\mathrm{x}$ deformação como mostrado na figura 3.10. 


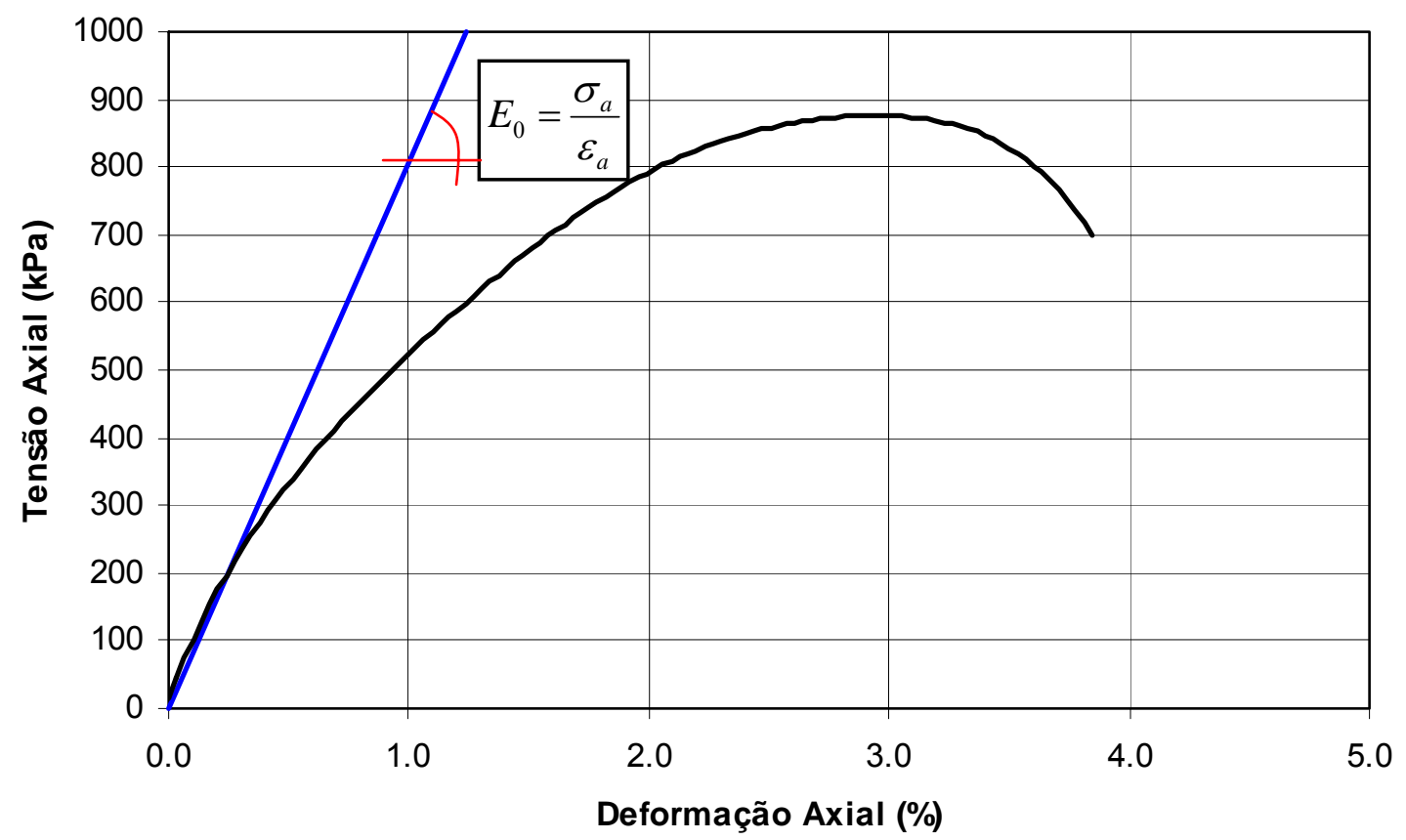

FIGURA 3.10 - Exemplo da estimativa de $E_{0}$ a partir da curva tensão $x$ deformação.

\subsubsection{2 - Ensaios de Compressão Diametral}

O ensaio de compressão diametral ou Ensaio Brasileiro foi desenvolvido por Lobo Carneiro e Barcellos para determinar a resistência à tração de corposde-prova de concreto com cimento Portland (MOLINA, 2004). Este ensaio consiste em submeter o corpo-de-prova sem confinamento a uma carga de compressão ao longo de um plano diametral, aplicada através de dois frisos metálicos colocados em lados diametralmente opostos.

Neste ensaio, além de surgir a tensão de tração horizontal $\left(\sigma_{x}\right)$ também existem, no plano vertical, tensões de compressão $\left(\sigma_{y}\right)$. Desse modo, a real causa da ruptura deve refletir a ação da tensão vertical de compressão combinada à tensão horizontal de tração (GOODMAN, 1989).

Segundo a teoria de ruptura de Griffith, o ponto crítico deve ser o centro da amostra onde a relação entre a tensão de compressão e de tração é igual a 3. Com uma razão de tensão principal de 3 , a ruptura deve resultar da aplicação apenas da tensão de tração, sem qualquer interferência da compressão para a ruptura eventual do plano. 
A tensão de tração por compressão diametral é dada pela expressão 3.3 e a tensão de compressão num dado ponto do diâmetro vertical do cilindro é calculada pela equação 3.4 .

Tensão de tração no centro da amostra:

$$
\sigma_{\mathrm{x}}=\frac{2 \mathrm{~F}}{\pi \mathrm{td}}
$$

Tensão de compressão em um ponto qualquer do diâmetro vertical:

$$
\sigma_{y}=\frac{2 F}{\pi t d}\left(\frac{d^{2}}{r(d-r)}-1\right)
$$

Onde $r$ e $(d-r)$ são as distâncias do ponto aos dois frisos de aplicação de carga, respectivamente. Assim, para se calcular a tensão vertical de compressão no centro do corpo-de-prova tem-se que $r$ e $(d-r)$ serão iguais a d/2. Logo a equação 3.4 poderá ser escrita da seguinte forma:

$$
\begin{gathered}
\sigma_{y}=\frac{2 F}{\pi t d}\left(\frac{d^{2}}{(d / 2)^{2}}-1\right) \\
\sigma_{y}=\frac{2 F}{\pi t d}\left(\frac{d^{2}-d^{2} / 4}{d^{2} / 4}\right) \\
\sigma_{y}=\frac{6 F}{\pi t d}
\end{gathered}
$$

Onde:

$\sigma_{\mathrm{x}}=$ resistência à tração por compressão diametral $(\mathrm{kPa})$;

$\sigma_{\mathrm{y}}=$ resistência à compressão vertical $(\mathrm{kPa})$;

$\mathrm{F}=$ carga diametral aplicada $(\mathrm{kgf})$;

$\mathrm{t}=$ altura do corpo-de-prova $(\mathrm{m})$;

$\mathrm{d}$ = diâmetro do corpo-de-prova $(\mathrm{m})$;

$r$ e $(d-r)$ = distâncias de um ponto qualquer do diâmetro vertical aos dois frisos de aplicação de carga (m). 
A figura 3.11 apresenta um esquema de distribuições de tensões de um corpo-de-prova cilíndrico submetido ao ensaio de compressão diametral.

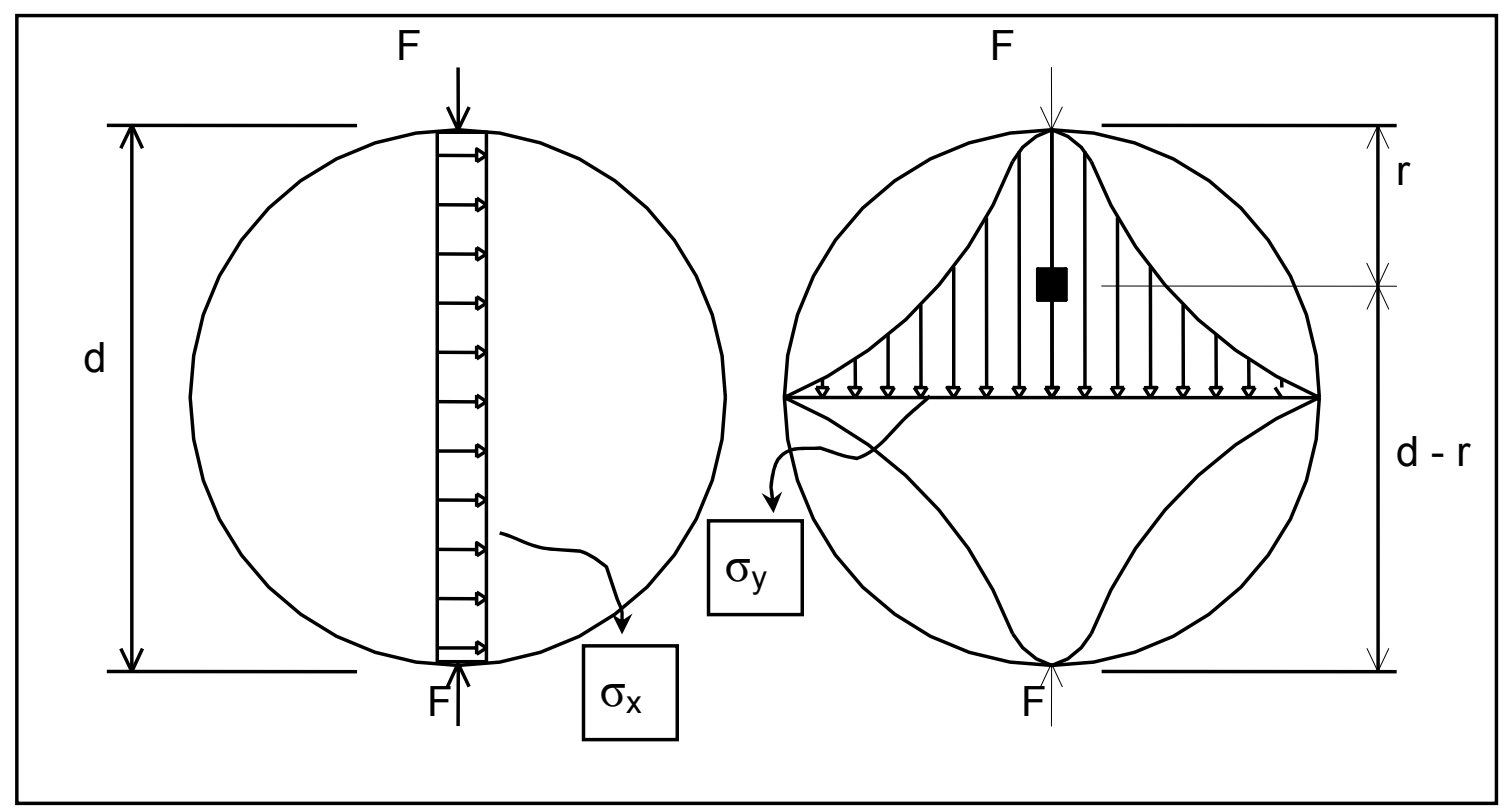

FIGURA 3.11 - Esquema de distribuição de tensões no ensaio de compressão diametral ou Ensaio Brasileiro.

Os ensaios de compressão diametral foram realizados com corpos-deprova com $5 \mathrm{~cm}$ de diâmetro e $5 \mathrm{~cm}$ de altura, compactados dinamicamente no compactador de mini-MCV na umidade ótima e massa especifica seca máxima. O método de ensaio do DNER ME - 181/94 foi utilizado como referência para a realização desse tipo de ensaio.

Para a realização dos ensaios de compressão diametral, foram moldados três corpos-de-prova para cada um dos quatro teores de cinza utilizados nas misturas com os solos, num subtotal de 12 corpos-de-prova. Considerando que foram empregados três períodos de cura, teve-se, ao fim, 36 corpos-de-prova para cada tipo de solo. Para as misturas de solo-cinza-cal foram moldados a mesma quantidade de corpos-de-prova, ou seja, 36 por tipo de solo.

Os valores de $\sigma_{x}$ e $\sigma_{y}$ obtidos através dos ensaios de compressão diametral foram empregados no traçado dos círculos de Mohr Coulomb conforme será descrito no próximo item. 


\subsubsection{3 - Cálculo do Intercepto Coesivo e do Ângulo de Atrito através dos Resultados de RCS e RTCD}

O critério de Mohr Coulomb é fácil de trabalhar e oferece uma forma útil para manipulação em situações práticas quando de deseja conhecer o comportamento quanto à ruptura de um material. Entretanto, segundo Goodman (1989), a envoltória de ruptura é freqüentemente uma curva descendente, ou seja, o intercepto coesivo obtido pelo critério de Mohr Coulomb é superestimado.

Assim, ainda segundo Goodman (1989), um critério mais preciso de ruptura pode ser determinado ajustando-se uma envoltória empírica para uma série de círculos de Mohr Coulomb representando tensões principais nas condições de pico dos ensaios em laboratório. A figura 3.12 apresenta a comparação entre o critério de Mohr Coulomb e o critério empírico de ruptura definidos a partir de uma série de ensaios de laboratório.

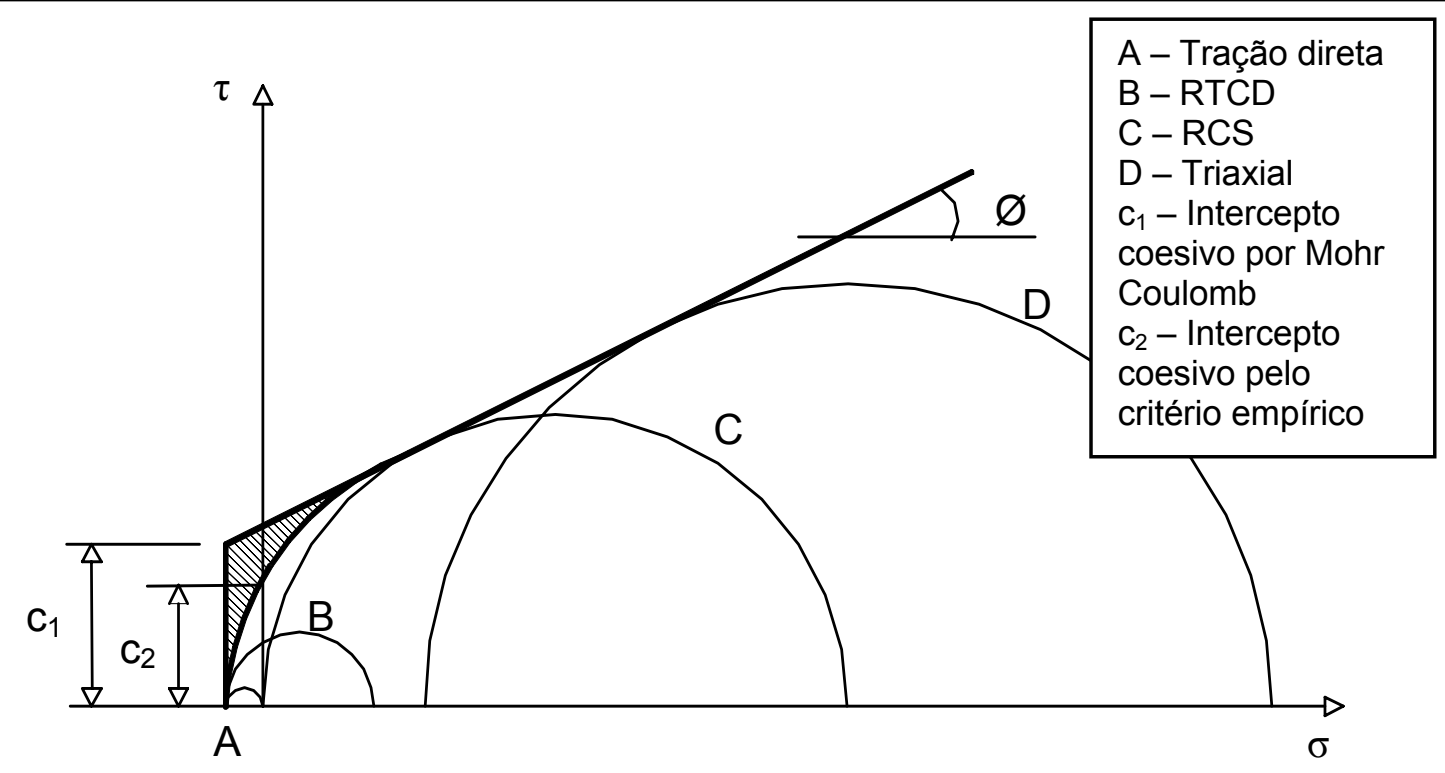

FIGURA 3.12 - Comparação entre o critério de ruptura empírico e o critério de ruptura de Mohr Coulomb.

Através da figura 3.12, verifica-se que o intercepto coesivo determinado pelo critério de Mohr Coulomb é maior do que o encontrado pelo critério de ruptura empírico. Além disso, a envoltória de ruptura é curva, principalmente para tensões pequenas. Desse modo, o ângulo de atrito pelo método empírico 
varia ao longo da curva, diferentemente do que acontece pelo critério de Mohr Coulomb.

Com os valores $\sigma_{x}$ e $\sigma_{y}$ obtidos pelo ensaio de compressão diametral e com os resultados de resistência à compressão simples $\left(\sigma_{1}\right)$ foram traçados os círculos de Mohr para esses dois ensaios. Em seguida, traçou-se uma reta tangente a esses dois círculos, sendo que, o intercepto coesivo é dado pela altura do eixo das abscissas até o ponto onde essa reta intercepta o eixo das ordenadas. O ângulo de atrito é a inclinação dessa reta, porém, como visto anteriormente, esse parâmetro deve ser analisado com cuidado devido ao fato de que a envoltória real de ruptura é curva. A figura 3.13 ilustra a forma como foram traçadas as envoltórias de rupturas através dos ensaios de compressão diametral e de compressão simples para esta pesquisa.

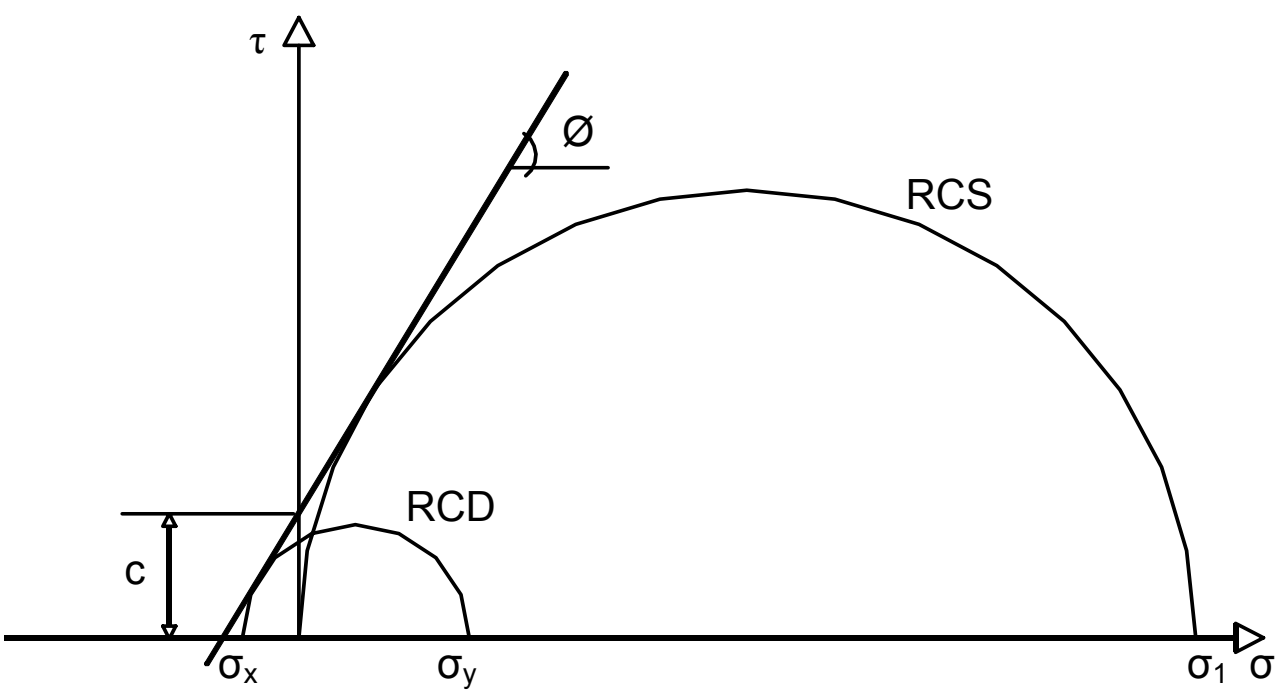

FIGURA 3.13 - Esquema do traçado dos círculos de Mohr Coulomb a partir dos resultados dos ensaios de compressão simples e compressão diametral para determinação do intercepto coesivo (c) e do ângulo de atrito $(\varnothing)$.

\subsubsection{4 - Ensaios de CBR}

O ensaio de CBR foi realizado para avaliar a influência das adições de cinza pesada e da cal na capacidade de suporte dos solos. Este ensaio foi 
executado na energia intermediária segundo o procedimento especificado pela ABNT NBR 9895 para todas as misturas de solo-cinza e solo-cinza-cal. Nesta etapa, foram realizados oito ensaios de CBR.

\subsubsection{5 - Cura dos Corpos-de-prova}

Para avaliar a existência e o efeito das reações pozolânicas sobre as misturas de solo-cinza e solo-cinza-cal, os corpos-de-prova dos ensaios de compressão simples e compressão diametral após a moldagem, foram identificados, embalados com filme plástico e submetidos ao processo de cura em câmara úmida. Estes corpos-de-prova somente foram ensaiados após decorridos períodos de cura diferentes (0, 28 e 84 dias). Os ensaios de CBR foram realizados da maneira tradicional.

\subsubsection{6 - Análise dos Resultados}

A análise dos resultados de resistência à compressão simples e resistência à tração por compressão diametral foi feita com base nos valores de média e desvio padrão aplicando-se o teste de Grubbs para identificação de outliers.

O teste de Grubbs (GRUBBS, 1969) ${ }^{6}$ é uma ferramenta estatística empregada para detectar outliers em conjunto de resultados de ensaios e é aplicável apenas para resultados cuja distribuição se aproxime da normal. Esta ferramenta detecta um outlier por vez, após a retirada deste valor incorreto, novas interações são realizadas, até que não reste mais nenhum outlier.

O teste de Grubbs é definido pelas seguintes hipóteses:

$\mathrm{H}_{\mathrm{o}}=$ não há outliers entre os resultados;

$\mathrm{H}_{\mathrm{a}}=$ há pelo menos um outlier entre os resultados.

${ }^{6}$ GRUBBS, F. (1969). Procedures for detecting outlying observations in samples.

Technometrics, v.11, n. 1, p. 1-21. 
Para a aplicação deste teste deve-se verificar, dentre os dados de um mesmo tratamento, quais são os valores máximo e mínimo. De posse destes valores, calcular a estatística "G", definida como:

$$
G=\frac{m a ́ x|y i-y|}{s}
$$

Onde:

$\mathrm{y}_{\mathrm{i}}=$ valores máximo e mínimo dentro do conjunto de resultados de um mesmo tratamento;

$\mathrm{y}=$ média dos resultados de um mesmo tratamento;

$\mathrm{s}=$ desvio padrão dos resultados de um mesmo tratamento.

A estatística " $G$ " deve ser comparada com o valor de $G_{\text {crítico }}$ que depende do número de repetições e do grau de confiança. O resultado é considerado

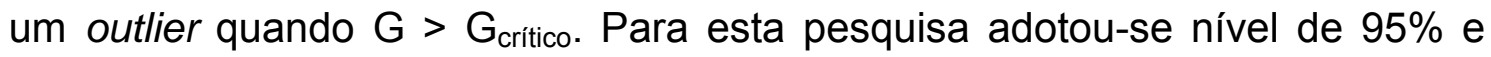
foram feitas três observações para cada ensaio de resistência à compressão simples e resistência à tração por compressão diametral sendo o $G_{\text {crítico }}$ utilizado igual a 1. 


\section{CAPÍTULO 4}

\section{APRESENTAÇÃO E DISCUSSÃO DOS RESULTADOS}

\section{1 - INTRODUÇÃO}

Os resultados apresentados e discutidos neste capítulo dizem respeito aos ensaios realizados para a avaliação do aproveitamento da cinza pesada, quando incorporada a solos.

O método experimental, conforme descrito no capítulo 2, foi dividido em duas etapas: Estudo Preliminar e Estudo Definitivo. Desta maneira, os resultados referentes a essas etapas serão apresentados e discutidos nesta ordem.

\section{2 - ESTUDO PRELIMINAR}

No estudo preliminar, foram determinados, através do ensaio de miniCBR, os parâmetros de compactação das misturas de solo-cinza massa específica seca máxima e teor de umidade ótimo, além da expansão, contração, mini-CBR após 24 horas de imersão e imediato. Em seguida, foi feita a avaliação da necessidade de cal por meio da realização dos ensaios de resistência à compressão simples em corpos-de-prova compactados de solocinza, ensaiados após 28 dias de cura em câmara úmida. Os resultados destes ensaios serão apresentados e discutidos no item Estudo Definitivo (item 4.3). 


\subsection{1 - Ensaios de Mini-CBR}

Os ensaios de mini-CBR foram realizados na energia intermediária para misturas de solo e cinza pesada obtendo-se, assim, os parâmetros de compactação: massa específica seca máxima e teor de umidade ótimo, além dos valores de mini-CBR imediato e após 24 horas de imersão e também a expansão e contração das misturas.

As curvas de compactação, através das quais se obteve os valores de massa específica seca máxima e teor de umidade ótimo das misturas dos solos com os teores de cinza pesada, foram semelhantes quanto ao comportamento e também quanto a forma. A figura 4.1 ilustra o comportamento das curvas de compactação em função das adições de cinza pesada ao solo JG.

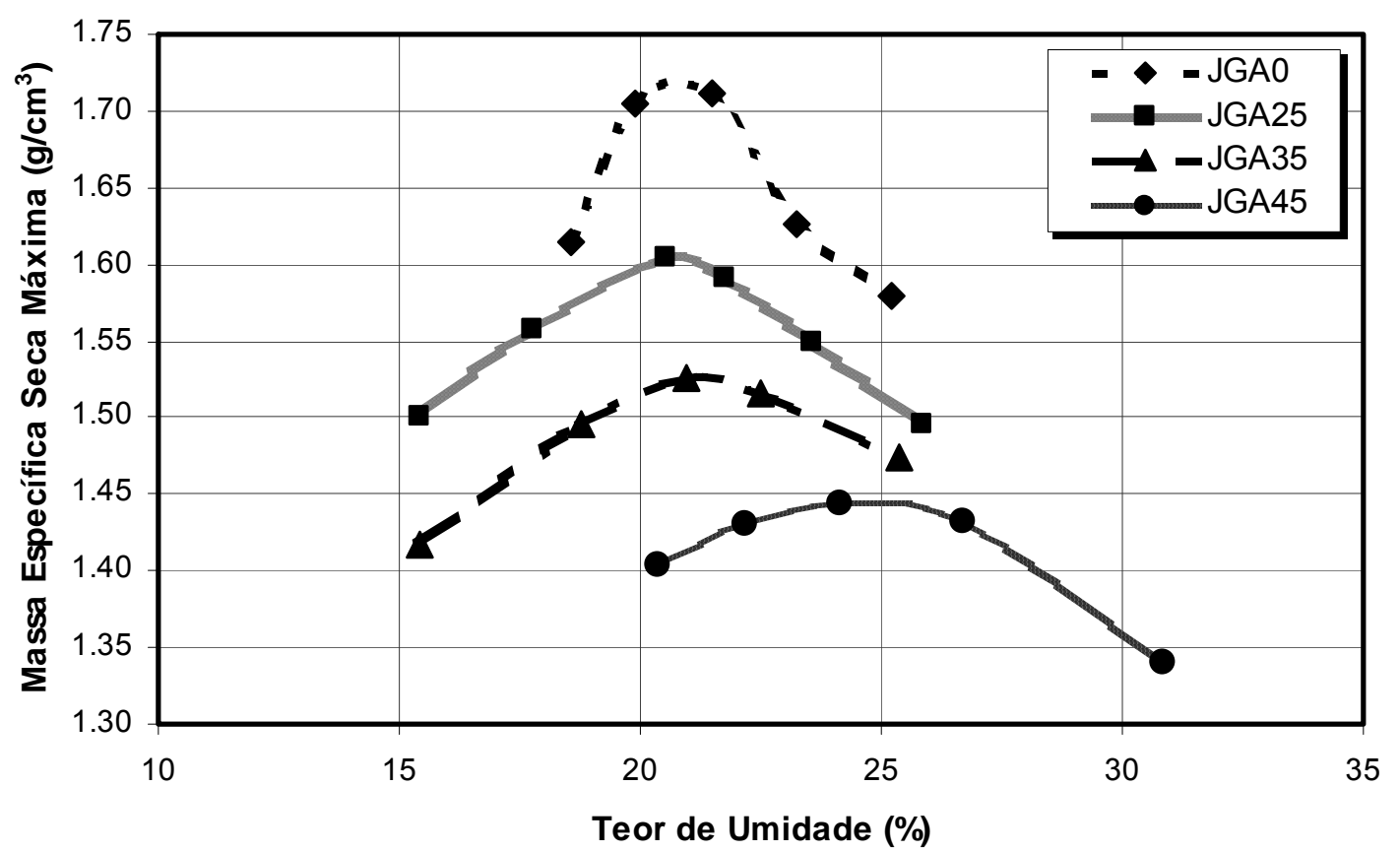

FIGURA 4.1 - Curvas de compactação das misturas do solo JG com cinza pesada.

Analisando-se a forma das curvas de compactação da figura 4.1, observa-se que a adição de cinza pesada produziu suas suavizações, ou seja, a massa especifica seca máxima das misturas com cinza pesada é menos sensível à variação do teor de umidade de compactação do que os solos sem adição de cinza. Verifica-se também que o aumento no teor de cinza pesada 
adicionada aos solos resultou na diminuição das massas específicas secas máximas e no aumento dos teores de umidade ótimos das misturas.

A tabela 4.1 apresenta os resultados de mini-CBR imediato e mini-CBR após 24 horas de imersão e também os valores de expansão e contração para a massa específica seca máxima e teor ótimo de umidade das misturas de solo-cinza.

TABELA 4.1 - Resultados de mini-CBR imediato, mini-CBR após 24 horas de imersão, expansão e contração para a massa específica seca máxima e teor de umidade ótimo das misturas de solo-cinza.

\begin{tabular}{|c|c|c|c|c|c|c|c|c|}
\hline Solo & Mistura & $\begin{array}{c}\rho_{\text {dmáx }} \\
\left(\mathrm{g} / \mathrm{cm}^{3}\right)\end{array}$ & $\begin{array}{l}W_{\circ} \\
(\%)\end{array}$ & $\begin{array}{c}\text { Mini- } \\
\text { CBR }_{\text {imediato }} \\
(\%)\end{array}$ & \begin{tabular}{|c|} 
Mini- \\
CBR $_{\text {após }}$ \\
$24 \mathrm{~h}(\%)$
\end{tabular} & $\begin{array}{l}\text { RIS } \\
(\%)\end{array}$ & $\begin{array}{c}\text { Expansão } \\
(\%)\end{array}$ & $\begin{array}{c}\text { Contração } \\
(\%)\end{array}$ \\
\hline \multirow{4}{*}{$\mathrm{TM}$} & $\mathrm{TMA}_{00}$ & 1,724 & 18,70 & 44,0 & 13,0 & 29,5 & 1,15 & 1,05 \\
\hline & $\mathrm{TMA}_{25}$ & 1,594 & 20,10 & 27,0 & 23,0 & 85,2 & 0,80 & 0,90 \\
\hline & $\mathrm{TMA}_{35}$ & 1,592 & 19,50 & 35,0 & 30,0 & 85,7 & 0,00 & 0,75 \\
\hline & $\mathrm{TMA}_{45}$ & 1,485 & 23,40 & 21,0 & 25,5 & 121,4 & 0,00 & 0,40 \\
\hline \multirow{4}{*}{ JG } & $\mathrm{JGA}_{00}$ & 1,720 & 20,60 & 46,0 & 25,0 & 54,3 & 0,20 & 1,60 \\
\hline & $\mathrm{JGA}_{25}$ & 1,604 & 20,40 & 45,0 & 38,0 & 84,4 & 0,00 & 0,95 \\
\hline & $\mathrm{JGA}_{35}$ & 1,526 & 20,60 & 44,0 & 40,0 & 90,9 & 0,00 & 0,55 \\
\hline & $\mathrm{JGA}_{45}$ & 1,445 & 25,00 & 25,0 & 28,0 & 112 & 0,00 & 0,25 \\
\hline \multirow{4}{*}{ SG } & $\mathrm{SGA}_{00}$ & 1,720 & 19,80 & 34,0 & 10,1 & 29,7 & 0,90 & 1,80 \\
\hline & $\mathrm{SGA}_{25}$ & 1,585 & 20,30 & 23,6 & 19,5 & 82,6 & 0,00 & 1,10 \\
\hline & $\mathrm{SGA}_{35}$ & 1,530 & 21,40 & 26,5 & 23,0 & 86,8 & 0,10 & 0,85 \\
\hline & $\mathrm{SGA}_{45}$ & 1,470 & 20,00 & 34,0 & 32,0 & 94,1 & 0,00 & 0,60 \\
\hline
\end{tabular}

Através da tabela 4.1 percebe-se que a massa específica seca máxima diminui com o aumento no teor de cinza pesada e que, na maior parte das vezes, o teor de umidade ótimo é maior para teores maiores de cinza. Entretanto, até $35 \%$ de cinza pesada o aumento no teor de umidade ótimo é geralmente pouco significante. Por exemplo, a maior diferença no teor de umidade ótimo para as misturas com $35 \%$ de cinza em relação às misturas sem cinza (solos puros) foi observada para a mistura SGA 35 , onde a diferença em relação ao solo puro foi de aproximadamente $1.6 \%$.

As figuras 4.2 e 4.3 ilustram o comportamento da massa específica seca máxima e do teor de umidade ótimo em função do teor de cinza pesada adicionada aos três solos, respectivamente. 


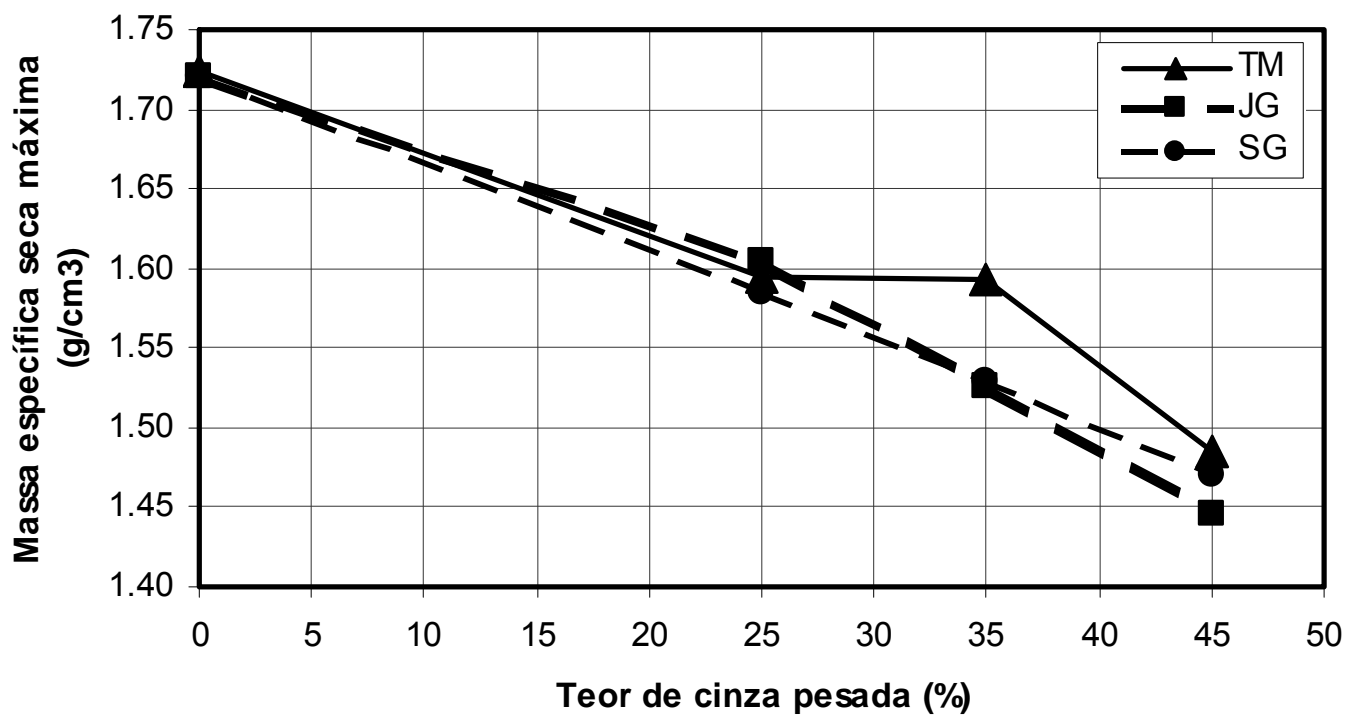

FIGURA 4.2 - Massa específica seca máxima das misturas de solo-cinza em função do teor de cinza pesada.

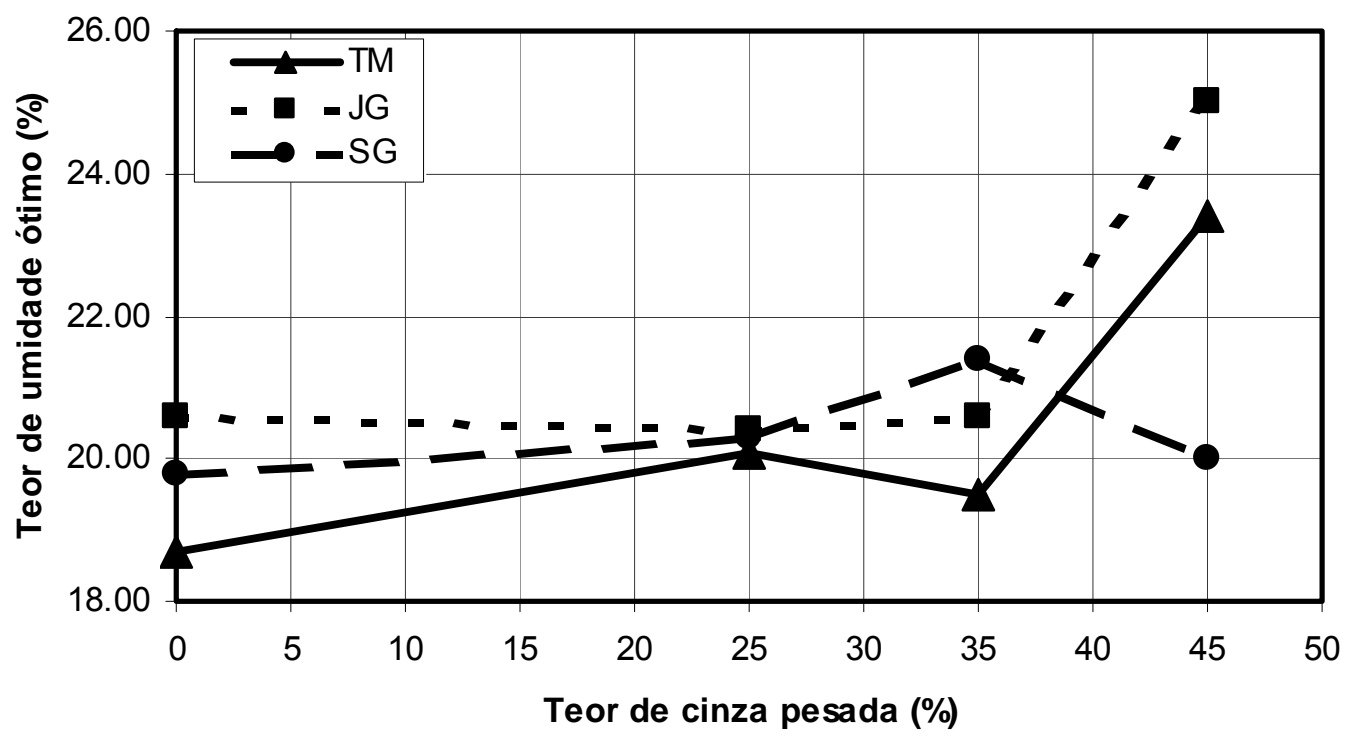

FIGURA 4.3 - Teor de umidade ótimo das misturas de solo-cinza em função do teor de cinza pesada.

Analisando-se a figura 4.2 nota-se que a redução de massa específica seca máxima em função do teor de cinza pesada foi quase que linear para as misturas dos três solos com cinza. A única exceção foi a mistura do solo TM com 35\% de cinza que apresentou praticamente o mesmo valor de massa específica seca máxima da mistura anterior $\left(\mathrm{TMA}_{25}\right)$. Já as umidades ótimas apresentaram pouca variação até $35 \%$ de cinza pesada (figura 4.3 ), sendo que com $45 \%$ as misturas dos solos JG e TM apresentaram elevação acentuada desse parâmetro enquanto que o solo SG apresentou uma redução. 
Ainda analisando-se a tabela 4.1 verifica-se que as adições de cinza pesada até $35 \%$ tiveram pouca influência nos valores de mini-CBR imediato para o solo laterítico JG. Contudo, os solos não lateríticos TM e SG apresentaram uma redução maior no valor desse parâmetro devido às adições de cinza pesada, ou seja, esse tipo de solo foi mais sensível às adições de cinza. Quanto aos valores de mini-CBR após 24 horas de imersão em água, percebe-se que ocorreu um aumento significativo até $35 \%$ de cinza e que para $45 \%$, os valores diminuíram consideravelmente para os solos TM e JG. Apenas o solo SG apresentou aumento no valor de mini-CBR após 24 horas de imersão para o teor de $45 \%$ de cinza. Esse comportamento evidencia a influência positiva da cinza pesada nos valores de mini-CBR após a imersão em água devido ao caráter granular e inerte da cinza.

O efeito benéfico das adições de cinza nos valores de mini-CBR após imersão também pode ser constatado através dos valores de RIS (relação entre mini-CBR após 24 horas de imersão e mini-CBR imediato expresso em porcentagem). Nota-se que alguns solos apresentaram valores de RIS não aceitáveis, aproximadamente $29 \%$ para os solos não lateríticos TM e SG. As adições crescentes de cinza proporcionaram o aumento desses valores chegando a alcançar mais de 100\%. Isto significa que a redução nos valores de mini-CBR após imersão foram menores para as misturas com teores maiores de cinza pesada do que para os solos puros, sendo que, em alguns momentos, os valores após imersão foram maiores do que os não imersos. Desse modo, pode-se dizer que a imersão exerce menor influência nos valores de mini-CBR após as adições de cinza pesada.

Ainda na tabela 4.1 verifica-se que todas as misturas de solo-cinza não apresentaram expansão ou apresentaram expansão praticamente nula. A mistura $\mathrm{TMA}_{25}$ foi a que apresentou maior expansão de todas as misturas solocinza, $0,8 \%$. Quanto às contrações, nota-se que as adições crescentes de cinza pesada provocaram reduções importantes nos valores.

As curvas de compactação, expansão, contração, mini-CBR imediato e mini-CBR após 24 horas de imersão em função do teor de umidade estão apresentadas no anexo A para todas as misturas de solo-cinza. 


\section{3 - ESTUDO DEFINITIVO}

Os resultados aqui apresentados referem-se aos ensaios de resistência à compressão simples, resistência à tração por compressão diametral e CBR, realizados com o propósito de avaliar as propriedades mecânicas das misturas estudadas.

Os resultados dos ensaios preliminares de resistência à compressão simples executados sem cura e após 28 dias de cura, para misturas de solocinza, com o objetivo de se verificar a ocorrência de reações pozolânicas, serão apresentados e discutidos de forma conjunta com os resultados obtidos aos 84 dias. Em seguida, serão analisados os efeitos dos períodos de cura e da adição de cal.

Após isso, serão apresentados os resultados dos ensaios de resistência à tração por compressão diametral, módulo tangente inicial, intercepto coesivo e ângulo de atrito para as misturas de solo-cinza e solo-cinza-cal. Por último serão apresentados e analisados os resultados de CBR, expansão com e sem cal e resistência à compressão simples após imersão em água.

\subsection{1 - Resistência à Compressão Simples}

A tabela 4.2 apresenta os valores médios de resistência à compressão simples obtidos através dos resultados apresentados no anexo B para os solos puros e para as misturas solo-cal, solo-cinza e solo-cinza-cal para todos os períodos de cura empregados. 
TABELA 4.2 - Resistência à compressão simples dos solos e das misturas de solo-cal, solo-cinza e solo-cinza-cal para todos os períodos de cura.

\begin{tabular}{|c|c|c|c|c|c|c|c|}
\hline \multirow{4}{*}{ Solo } & \multirow{2}{*}{$\begin{array}{c}\text { Teor de } \\
\text { Cinza } \\
(\%)\end{array}$} & \multicolumn{6}{|c|}{ Resistência à Compressão Simples (kPa) } \\
\cline { 3 - 8 } & & \multicolumn{7}{|c|}{0} & \multicolumn{3}{|c|}{ Período de Cura (dias) } \\
\cline { 3 - 8 } & & Sem Cal & Com Cal & Sem Cal & Com Cal & Sem Cal & Com Cal \\
\hline \multirow{4}{*}{ TM } & 0 & 872 & 1432 & 1127 & 1455 & 1294 & 1610 \\
\cline { 2 - 8 } & 25 & 274 & 571 & 366 & 849 & 340 & 991 \\
\cline { 2 - 8 } & 35 & 270 & 600 & 369 & 987 & 407 & 1216 \\
\cline { 2 - 8 } & 45 & 174 & 232 & 196 & 422 & 251 & 558 \\
\hline \multirow{4}{*}{ JG } & 0 & 1872 & 1331 & 1270 & 2168 & 1508 & 2577 \\
\cline { 2 - 8 } & 25 & 539 & 620 & 581 & 1334 & 630 & 1771 \\
\cline { 2 - 8 } & 35 & 406 & 662 & 489 & 987 & 472 & 1369, \\
\cline { 2 - 8 } & 45 & 132 & 295 & 231 & 557 & 184 & 752 \\
\hline \multirow{4}{*}{ SG } & 0 & 996 & 1388 & 885 & 1656 & 1216 & 1813 \\
\cline { 2 - 8 } & 25 & 415 & 643 & 443 & 1030 & 349 & 1278 \\
\cline { 2 - 8 } & 35 & 293 & 509 & 268 & 647 & 246 & 864 \\
\cline { 2 - 8 } & 45 & 267 & 440 & 327 & 798 & 341 & 1028 \\
\hline
\end{tabular}

${ }^{*}$ Para as misturas com cal o teor de cinza é reduzido em $3 \%$.

As adições crescentes de cinza pesada aos solos provocaram a diminuição das resistências à compressão simples em todos os períodos de cura, sendo que, geralmente, as resistências são menores para as misturas com maiores quantidades de cinza (tabela 4.2). Com adição de $25 \%$ de cinza, as resistências diminuíram em mais de $50 \%$ em relação aos solos puros, na maioria das vezes.

A figura 4.4 ilustra o comportamento descrito acima. Nessa figura, apresentam-se as variações de resistência à compressão simples imediata das misturas solo-cinza em função do teor de cinza pesada.

Através da observação da figura 4.4 verifica-se que as formas das curvas de resistência à compressão simples em função do teor de cinza pesada são relativamente parecidas para os três solos. O solo laterítico JG foi o que apresentou maior valor de resistência à compressão simples, entretanto, também foi o que apresentou maior diminuição de resistência após a adição de $25 \%$ de cinza. 


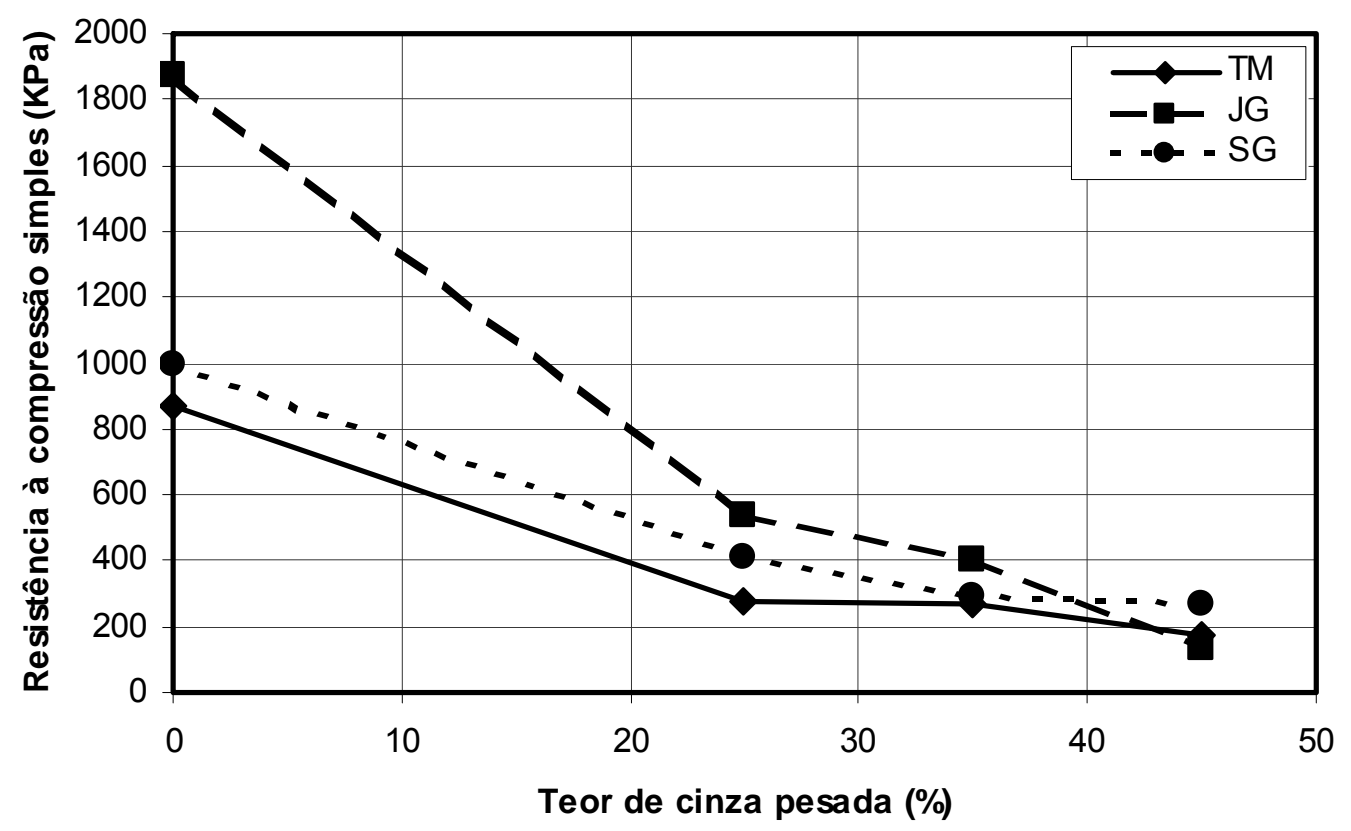

FIGURA 4.4 - Variação das resistências à compressão simples imediatas das misturas solo-cinza em função do teor de cinza pesada.

Ainda pela análise da figura 4.4 nota-se que após o teor de $25 \%$ as variações de resistência à compressão simples são menores de um teor para outro de cinza, ou seja, as resistências das misturas de solo-cinza são menos influenciadas pela parcela de cinza.

Ao se observar a variação de resistência à compressão simples das misturas de solo-cinza (figura 4.5) ao longo dos períodos de cura para um mesmo teor de cinza, nota-se que ocorreram pequenos aumentos de resistência para a maioria das misturas de solo-cinza. O solo não laterítico TM foi o que apresentou maior ganho de resistência ao longo do tempo. As misturas desse solo com 35 e $45 \%$ de cinza pesada apresentaram 47 e $40 \%$ de ganho aos 84 dias de cura em relação ao ensaio imediato.

Porém, as misturas dos outros dois solos com cinza pesada apresentaram ganhos bem menores e, em alguns casos, ocorrendo até a redução da resistência ao longo do tempo. Desse modo, verificou-se a necessidade da adição de algo às misturas de solo-cinza que propiciasse reações pozolânicas com a cinza presente nas misturas com os solos, proporcionando ganhos importantes de resistência ao longo do tempo. 
A figura 4.5 ilustra o comportamento típico das resistências à compressão simples das misturas de solo-cinza ao longo do período de cura. Nessa figura está representada a variação das resistências à compressão simples em função do período de cura para as misturas do solo TM com cinza pesada.

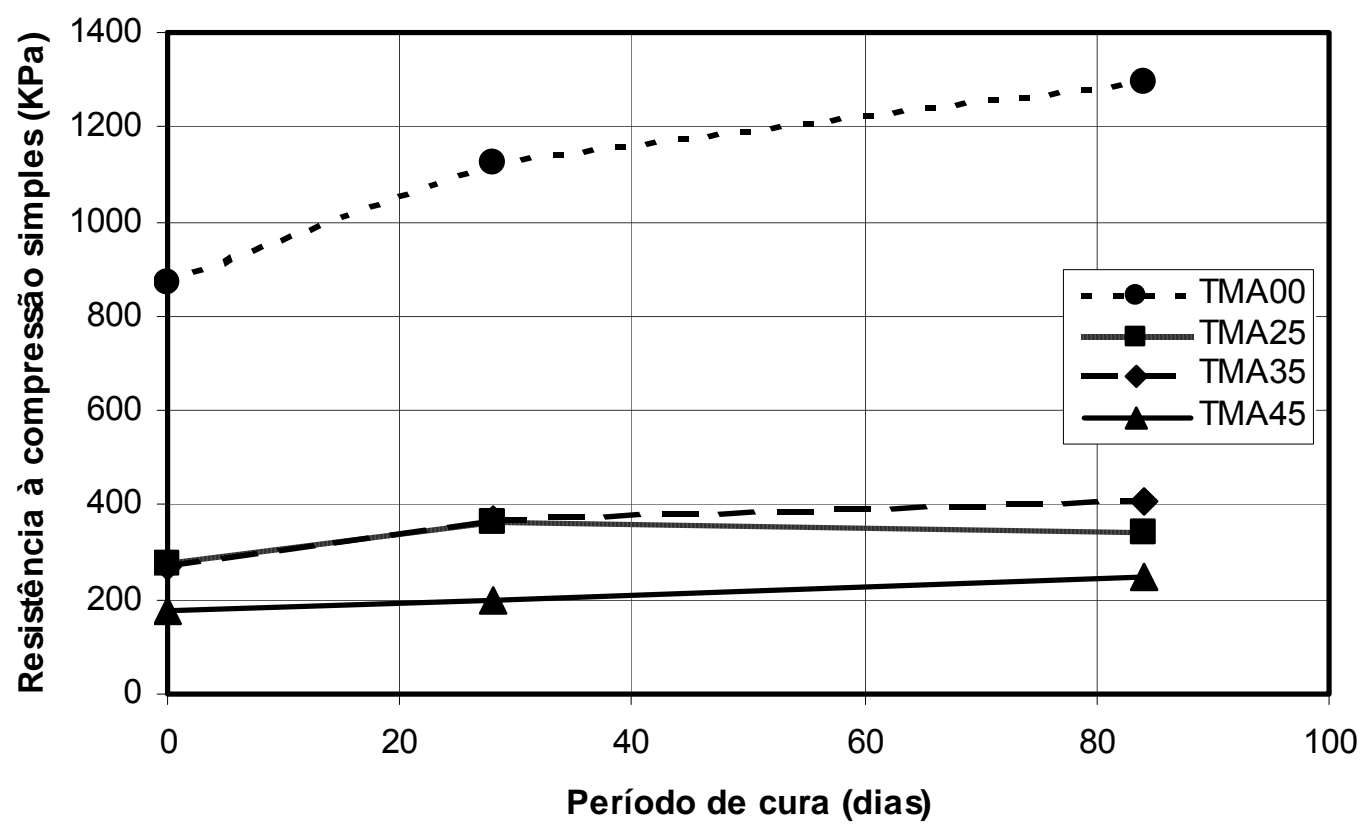

FIGURA 4.5 - Resistência à compressão simples em função do período de cura das misturas do solo laterítico TM com cinza pesada.

Através da figura 4.5 verifica-se de maneira clara que os ganhos de resistência, na maior parte dos casos, são reduzidos. Assim, se constata que não há reações pozolânicas consideráveis com a introdução dos teores de cinza pesada aos solos.

Visando aumentar as resistências à compressão simples das misturas e desencadear as reações pozolânicas devido à presença da cinza, substituiu-se $3 \%$ dos teores iniciais de cinza por cal hidratada.

Assim, analisando-se agora os resultados das misturas de solo-cinza-cal apresentados na tabela 4.2 , nota-se que também para essas misturas as resistências à compressão simples sofreram reduções consideráveis após as adições de cinza pesada em relação aos solos-cal, sendo que, geralmente, quanto maior a quantidade de cinza presente nas misturas, menor os valores 
de resistência. Contudo, a influência da adição de $3 \%$ de cal às misturas de solo-cinza foi significativamente positiva.

Através da análise das colunas de resistência à compressão simples imediata das misturas de solo-cinza-cal e das misturas de solo-cinza da tabela 4.2 constata-se que ocorreram aumentos significativos de resistência após a adição da cal. Somente o solo laterítico puro JG apresentou diminuição de resistência imediata após a adição de cal.

Geralmente, as misturas de solo-cinza em relação aos solos puros apresentaram ganhos percentuais muito maiores de resistência imediata após a adição de cal. A mistura do solo não laterítico TM com os teores de 22 e $32 \%$ de cinza pesada apresentou ganhos maiores que $100 \%$ depois da adição de cal, enquanto que o solo puro apresentou um ganho de aproximadamente $64 \%$. O mesmo comportamento ocorreu para as misturas dos outros dois solos com cinza, sendo que, aos 84 dias os ganhos percentuais de resistência para as misturas dos solos-cinza devido à adição da cal foram em torno de $200 \%$, enquanto que para os solos sem cinza os ganhos foram por volta de 24 e $68 \%$.

Vale ressaltar que na maioria das vezes os ganhos de resistência à compressão simples foram tão maiores quanto maior a quantidade de cinza presente nas misturas. Desse modo, pode-se afirmar que esses maiores ganhos, após adição de cal, se devem às reações imediatas ocorridas principalmente entre os compostos de cinza e a cal.

A figura 4.6 mostra a variação típica da resistência à compressão simples em função do teor de cinza pesada das misturas de solo-cinza-cal em comparação com as resistências das misturas de solo-cinza. 


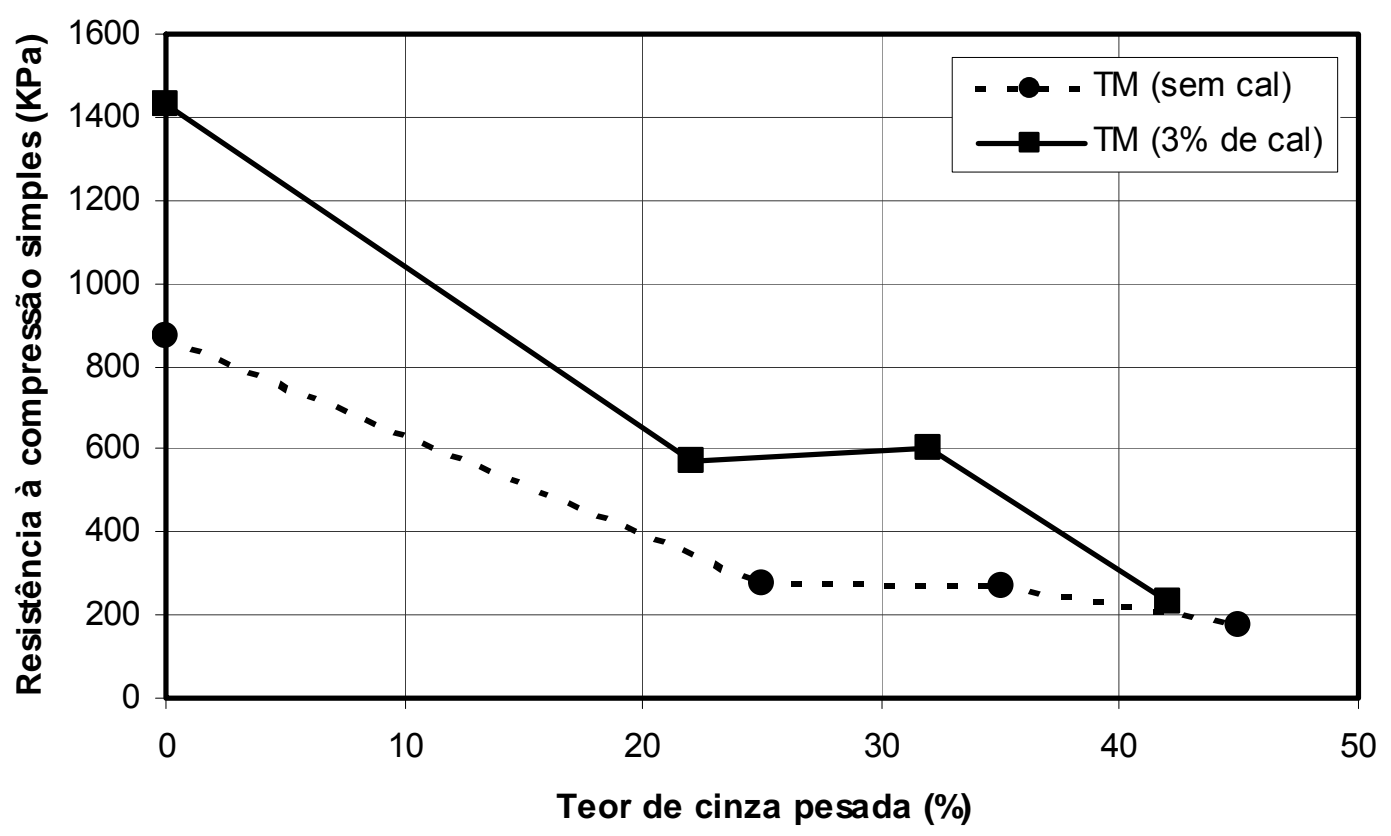

FIGURA 4.6 - Resistência à compressão simples imediata em função do teor de cinza pesada das misturas do solo TM com cinza pesada e cal em comparação com as misturas desse solo com apenas cinza.

Através da figura 4.6 observa-se o efeito positivo da adição de cal na resistência à compressão simples imediata das misturas de solo-cinza, ou seja, ocorreram reações imediatas que proporcionaram essa melhora de comportamento.

Analisando-se os ganhos de resistência à compressão simples das misturas de solo-cinza depois da adição da cal para os outros dois períodos de cura (28 e 84 dias), através da tabela 4.2, verifica-se que quanto maior o período de cura, maior é o ganho de resistência em relação às misturas de solo-cinza, indicando, dessa maneira, a ocorrência de reações lentas de cimentação das partículas ao longo do tempo, que conduzem a aumentos expressivos de resistência à compressão simples.

A figura 4.7 ilustra o desenvolvimento típico da resistência à compressão simples em função do tempo de cura para as misturas de solo-cinza-cal. 


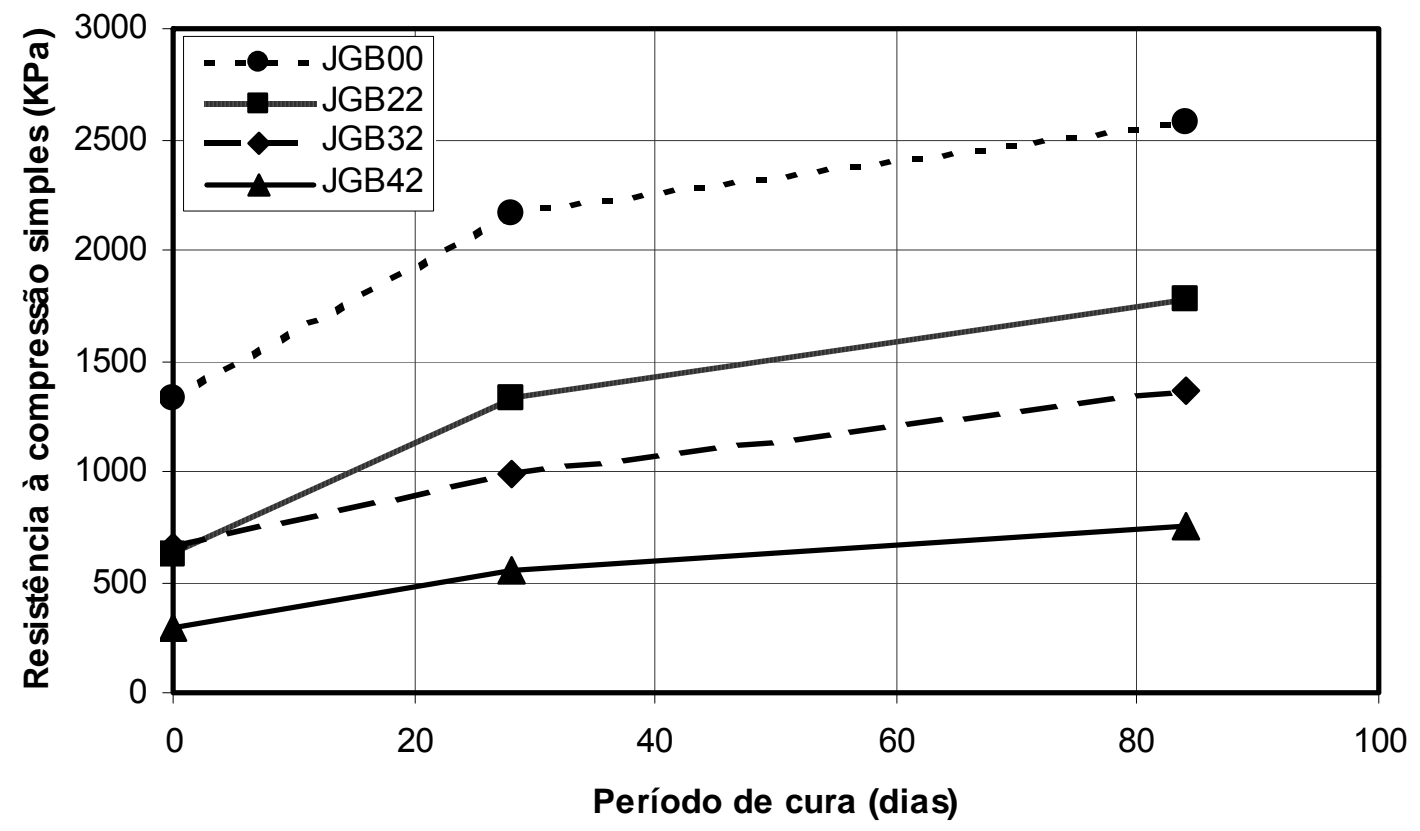

FIGURA 4.7 - Resistência à compressão simples em função do período de cura para as misturas do solo JG com cinza pesada e cal.

Através da análise conjunta da figura 4.7 e da tabela 4.2 observa-se que há ocorrência de reações pozolânicas significativas ao longo do tempo para as misturas, que alcançam, na maioria das vezes, aos 84 dias resistências à compressão simples maiores do que $1000 \mathrm{kPa}$ para as misturas de solo-cinzacal e acima de $1600 \mathrm{kPa}$ para os solos puros. Pela forma das curvas percebese que a maior parte das reações ocorridas entre a cinza e a cal acontecem até 28 dias de cura, sendo que após esse período a taxa de aumento decresce.

Ainda em relação a tabela 4.2 e tomando-se como base o critério de Thompson $^{7}$ apud Lima (1981) que diz que para um solo ser reativo à cal o ganho mínimo após a adição de cal deve ser de $338 \mathrm{kPa}$, verifica-se que apenas os solos puros não lateríticos TM e SG na condição sem cura prévia se mostraram reativos à cal. Entretanto, aos 84 dias de cura, todos os solos e todas as misturas de solo-cinza apresentaram ganhos superiores ao especificado pelo método, com exceção do solo TM e da mistura desse solo com $42 \%$ de cinza pesada, isto é, aos 84 dias de cura quase a totalidade das misturas de solo-cinza foi reativa à adição de $3 \%$ de cal.

\footnotetext{
7 THOMPSON, M. R. (1967). Engineering properties of lime-soil mixtures. ASTM, paper n. 78, $66 \mathrm{p}$.
} 
Segundo o critério do Departamento de Estradas do Texas, na condição sem cura, apenas os solos puros poderiam ser empregados em camadas de base de pavimentos, uma vez que apresentaram resistência à compressão simples superior a $677 \mathrm{kPa}$. Contudo, a mistura do solo laterítico com 25 e $35 \%$ de cinza e a mistura do solo não laterítico SG com $25 \%$ de cinza pesada se adequariam ao uso em camadas de sub-bases de pavimentos, já que as resistências obtidas para essas misturas foram maiores que $338 \mathrm{kPa}$. Aos 84 dias, além dessas, as misturas do solo TM com 25 e 35\% de cinza e do solo SG com $45 \%$ também poderiam ser utilizadas em camadas de sub-bases.

Com adição de $3 \%$ de cal todos os solos sem cinza se adequariam ao uso em camadas de base, uma vez que apresentaram resistências à compressão simples imediata consideravelmente superiores ao mínimo especificado. Ainda na condição sem cura quase todas as misturas de solocinza-cal poderiam ser empregadas em camadas de sub-bases com exceção das misturas $\mathrm{TMB}_{42}$ e $\mathrm{JGB}_{42}$. Já aos 84 dias todas as misturas solo-cal e solocinza-cal, com exceção da mistura $\mathrm{TMB}_{42}$, superam com certa folga a resistência mínima exigida para camadas de base.

\subsection{2 - Módulo Tangente Inicial}

Com as cargas e os deslocamentos obtidos durantes os ensaios de resistência à compressão simples foi possível calcular as tensões e deformações de ruptura e, traçando-se a curva tensão-deformação, pôde-se determinar o módulo tangente inicial dos solos e de todas as misturas.

Durante a realização dos ensaios preliminares de resistência à compressão simples verificou-se que, para as misturas de solo-cinza, a curva tensão-deformação não se ajusta a uma hipérbole, ou seja, não foi possível determinar o módulo tangente inicial segundo o critério de Ducan e Chang (1970). Dessa maneira, determinou-se o módulo tangente inicial de todas as misturas de solo-cinza, de solo-cinza-cal e dos solos sem adição, traçando-se uma reta tangente no inicio da curva tensão-deformação. 


\subsubsection{1 - Influência das adições de cinza, cal e do período de cura no módulo tangente inicial das misturas}

Os valores de módulo tangente inicial de todas as misturas solo-cinza, solo-cinza-cal, solo-cal e dos solos puros, para todos os períodos de cura, estão apresentados na tabela 4.3.

TABELA 4.3 - Módulo tangente inicial dos solos e das misturas de solocal, solo-cinza e solo-cinza-cal para todos os períodos de cura.

\begin{tabular}{|c|c|c|c|c|c|c|c|}
\hline \multirow{4}{*}{ Solo } & \multirow{4}{*}{$\begin{array}{c}\text { Teor de } \\
\text { Cinza } \\
(\%)\end{array}$} & \multicolumn{6}{|c|}{ Módulo Tangente Inicial (MPa) } \\
\hline & & \multicolumn{6}{|c|}{ Período de Cura (dias) } \\
\hline & & \multicolumn{2}{|c|}{0} & \multicolumn{2}{|c|}{28} & \multicolumn{2}{|c|}{84} \\
\hline & & Sem Cal & Com Cal & Sem Cal & Com Cal & Sem Cal & Com Cal \\
\hline \multirow{4}{*}{ TM } & 0 & 80 & 100 & 130 & 197 & 77 & 213 \\
\hline & 25 & 4 & 15 & 9 & 49 & 8 & 76 \\
\hline & 35 & 4 & 11 & 9 & 32 & 8 & 72 \\
\hline & 45 & 6 & 4 & 4 & 6 & 4 & 8 \\
\hline \multirow{4}{*}{ JG } & 0 & 147 & 59 & 162 & 170 & 155 & 196 \\
\hline & 25 & 22 & 13 & 42 & 82 & 45 & 128 \\
\hline & 35 & 32 & 42 & 33 & 72 & 38 & 112 \\
\hline & 45 & 6 & 7 & 9 & 19 & 15 & 39 \\
\hline \multirow{4}{*}{ SG } & 0 & 50 & 53 & 67 & 140 & 51 & 153 \\
\hline & 25 & 8 & 13 & 10 & 34 & 8 & 58 \\
\hline & 35 & 5 & 12 & 7 & 12 & 4 & 19 \\
\hline & 45 & 10 & 14 & 14 & 46 & 21 & 73 \\
\hline
\end{tabular}

${ }^{*}$ Para as misturas com cal o teor de cinza é reduzido em $3 \%$.

As adições de cinza pesada aos solos ocasionou elevada diminuição do módulo tangente inicial, ou seja, as misturas solo-cinza apresentaram maior deformação para um mesmo nível de tensão. Na condição sem cura e com $25 \%$ de cinza incorporada aos solos, a redução no módulo tangente inicial foi entre 84 e $95 \%$. Para as outras misturas e os outros períodos de cura as reduções foram sempre maiores que $70 \%$.

As variações do módulo tangente inicial em função dos teores de cinza pesada das misturas solo-cinza para todos os períodos de cura foram relativamente parecidas. A figura 4.8 ilustra a variação do módulo tangente inicial em função do teor de cinza para as misturas solo-cinza sem cura. 


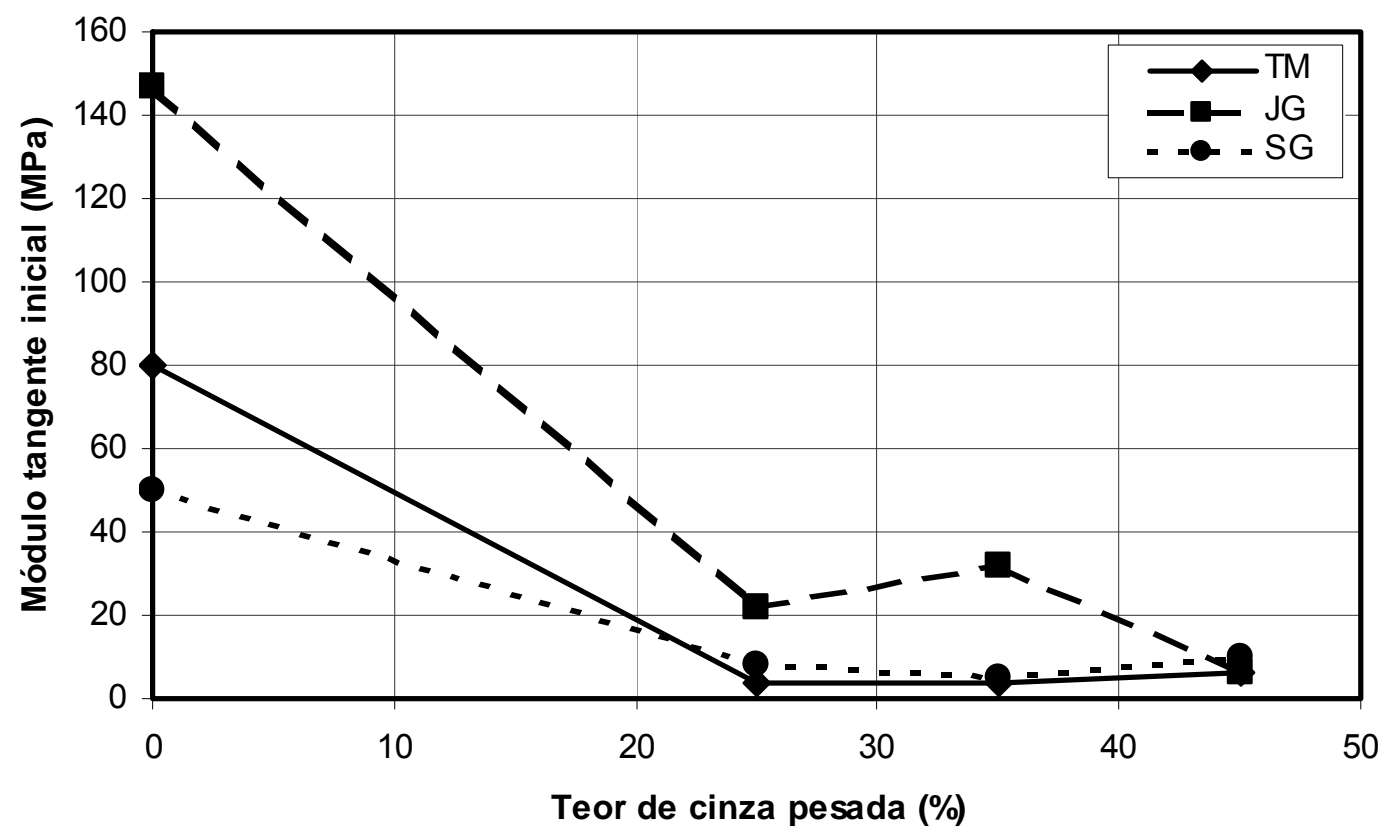

FIGURA 4.8 - Variação do módulo tangente inicial imediato das misturas de solo-cinza em função do teor de cinza pesada.

Através da observação da figura 4.8, constata-se que adições de cinza pesada conduzem a reduções consideráveis no valor do módulo tangente inicial. O solo JG e as misturas desse solo com cinza geralmente apresentaram valores maiores do que os outros dois solos não lateríticos. No entanto, foi esse solo o que apresentou maior redução do módulo tangente inicial após a adição de $25 \%$ de cinza pesada.

As misturas dos solos com $45 \%$ de cinza pesada conduziram a valores de módulo tangente muito semelhantes, ou seja, esse parâmetro parece não ser mais influenciado pela quantidade de cinza.

A influência do tempo de cura nos valores de módulo tangente inicial das misturas solo-cinza pode ser verificada através da tabela 4.3. Percebe-se que quase todas as misturas apresentaram pequenos ganhos para 28 dias, sendo que geralmente, os aumentos mais significativos foram para as misturas com o solo TM. Entretanto, os solos não lateríticos TM e SG apresentaram valores absolutos muito menores do que os apresentados pelo solo laterítico JG.

Já aos 84 dias as misturas do solo JG com cinza pesada foram as que apresentaram maiores ganhos de módulo tangente inicial em relação à 
condição sem cura. Mesmo assim, nenhuma mistura solo-cinza com solo laterítico apresentou módulo tangente inicial maior que 45MPa e que 21MPa, respectivamente para as com solos não lateríticos.

A figura 4.9 ilustra a variação dos valores de módulo tangente inicial em função do período de cura para as misturas solo-cinza do solo JG.

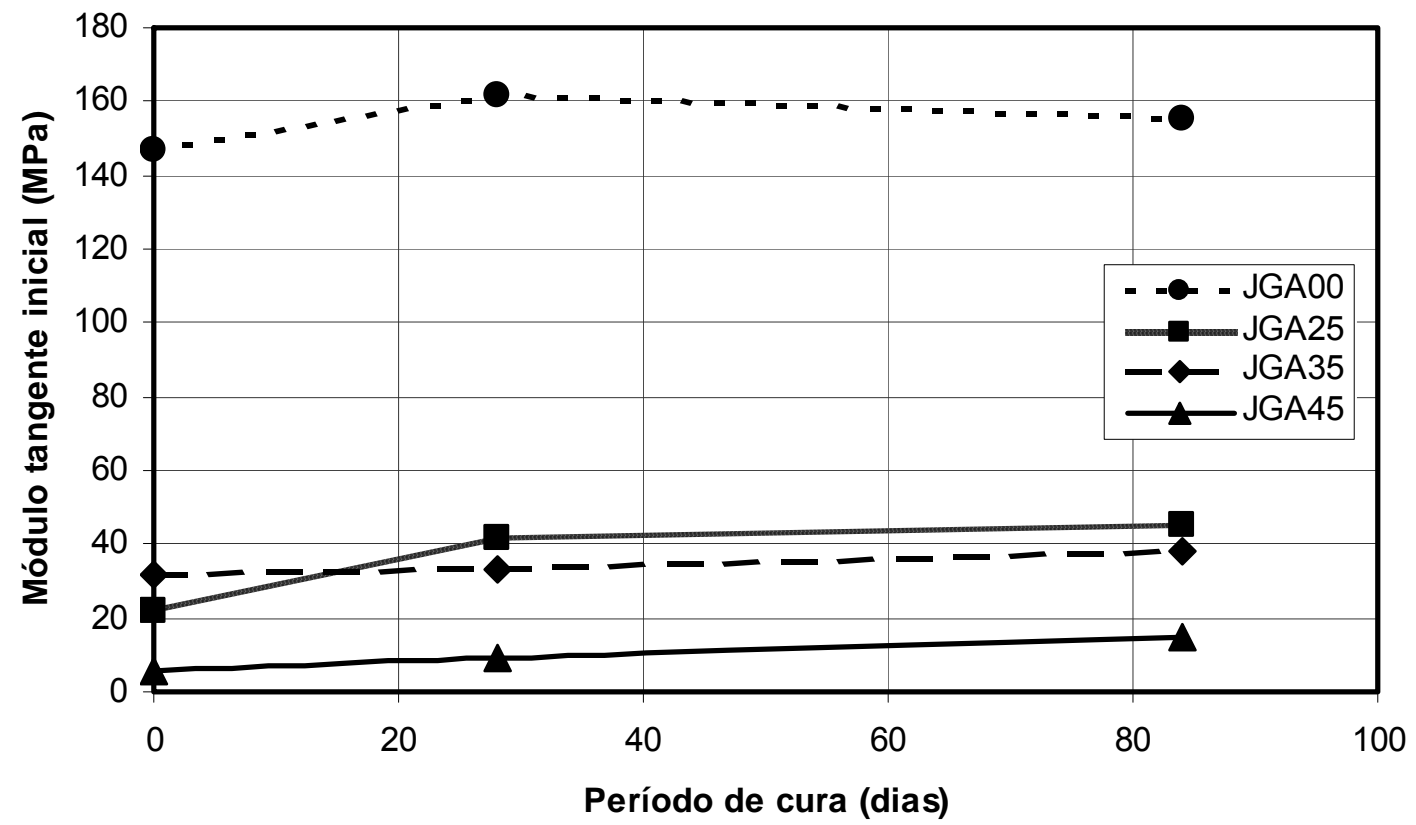

FIGURA 4.9 - Variação do módulo tangente inicial em função do período de cura para as misturas do solo laterítico JG com cinza pesada.

Através da análise da figura 4.9 verifica-se que ocorreu aumento dos valores de módulo tangente inicial ao longo do período de cura, principalmente até 28 dias para o solo JG e para a mistura desse solo com $25 \%$ de cinza. Contudo, os ganhos não alcançaram valores expressivos que se aproximassem dos valores obtidos para os solos puros.

A adição de cal às misturas solo-cinza também se mostrou positiva com respeito ao módulo tangente inicial, proporcionando a elevação dos valores desse parâmetro consideravelmente (tabela 4.3). Porém, todas as misturas solo-cinza-cal, para todos os períodos de cura, apresentaram reduções nos valores de módulo tangente inicial importantes para teores crescentes de cinza. 
As figuras 4.10 e 4.11 trazem as variações do módulo tangente inicial em função do teor de cinza das misturas de solo-cinza-cal do solo TM em comparação com as misturas de solo-cinza na condição sem cura e aos 84 dias, respectivamente.

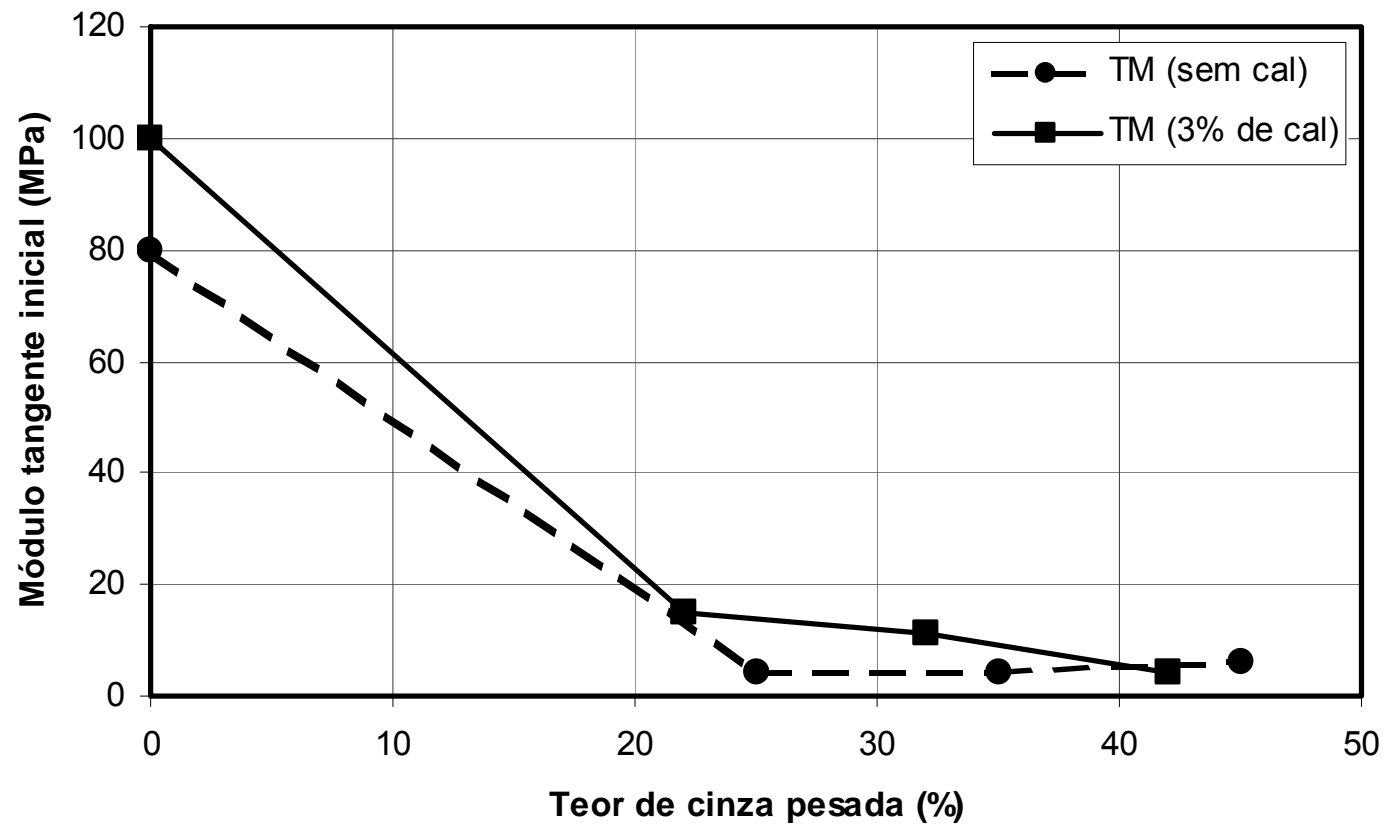

FIGURA 4.10 - Variação do módulo tangente inicial imediato das misturas de solo-cinza-cal em função do teor de cinza pesada em comparação com as misturas solo-cinza do solo TM na condição sem cura.

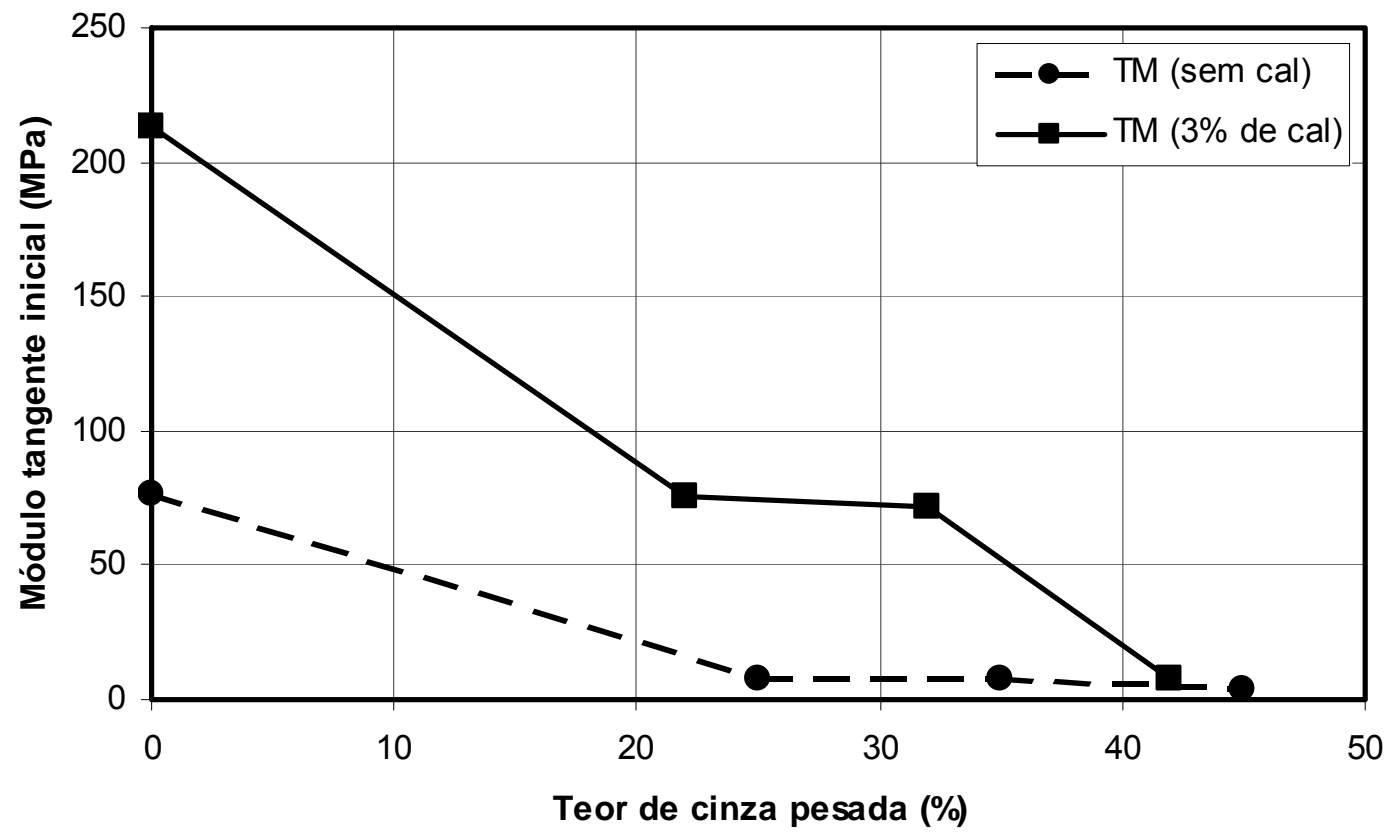

FIGURA 4.11 - Variação do módulo tangente inicial aos 84 dias de cura das misturas de solo-cinza-cal em função do teor de cinza pesada em comparação com as misturas solo-cinza do solo TM. 
A influência negativa da cinza pesada nas misturas de solo-cal também fica evidenciada através da observação das figuras 4.10 e 4.11. Nota-se que, geralmente, quanto maior a quantidade de cinza pesada presente nas misturas solo-cinza-cal, menor é o valor de módulo tangente inicial. Entretanto, com a adição de cal verifica-se uma pequena melhora imediata desse parâmetro para os solos puros e também para os solo-cinza.

Aos 84 dias, o efeito positivo da cal sobre o módulo tangente inicial fica ainda mais claro. Percebe-se pela figura 4.11 e pela tabela 4.3, que aos 84 dias de cura os valores de módulo tangente das misturas solo-cinza-cal foram muito maiores do que os das misturas solo-cinza, com exceção das misturas dos solos TM e JG com $42 \%$ de cinza e 3\% de cal, que apresentaram pouca diferença em relação às misturas sem cal.

As misturas do solo laterítico com cinza pesada apresentaram maiores ganhos de módulo tangente após a adição de cal em relação às misturas dos outros dois solos. Analisando-se novamente a tabela 4.3 observa-se que, na maioria dos casos, o aumento no valor do módulo tangente inicial para as mistura solo-cinza-cal foi consideravelmente maior para as misturas que continham cinza pesada do que para as misturas apenas de solo-cal.

Por exemplo, a mistura do solo laterítico JG com 3\% de cal apresentou, aproximadamente, $232 \%$ de aumento no valor de módulo tangente inicial aos 84 dias de cura em relação à condição sem cura. Já a mistura desse solo com $22 \%$ de cinza apresentou um ganho superior a $800 \%$ após a adição de $3 \%$ de cal. Assim, pode-se dizer que maior parte do aumento no valor do módulo tangente inicial deve-se, principalmente, às reações pozolânicas ocorridas entre os compostos de cinza e a cal.

A figura 4.12 mostra o desenvolvimento do módulo tangente inicial ao longo do período de cura para as misturas do solo laterítico JG com cinza pesada e $3 \%$ de cal. 


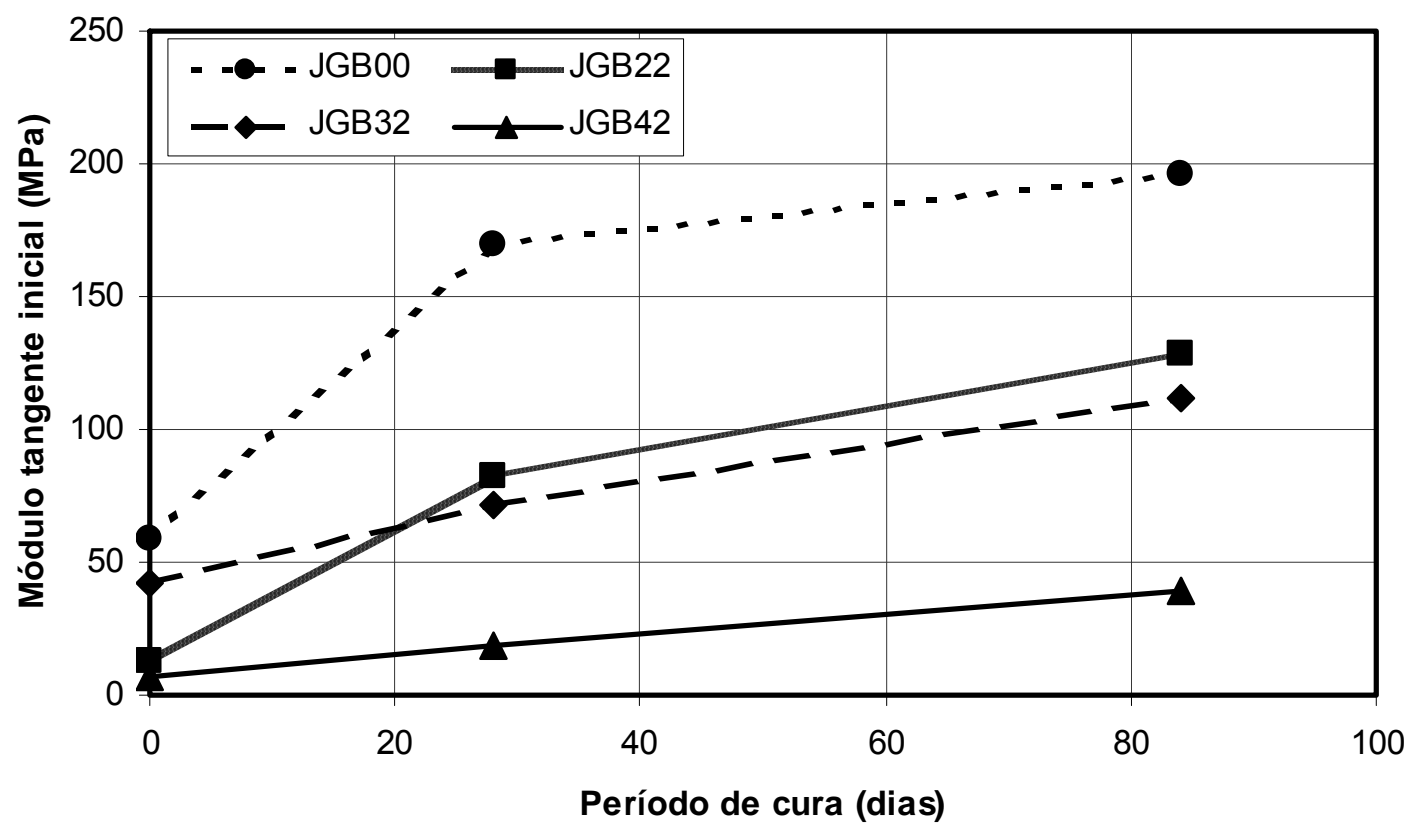

FIGURA 4.12 - Variação do módulo tangente inicial das misturas de solocinza-cal do solo JG em função do tempo de cura.

De acordo com a figura 4.12 percebe-se que o solo-cal apresentou maior taxa de aumento do módulo tangente inicial de zero para 28 dias, seguido da mistura desse solo com $22 \%$ de cinza pesada mais $3 \%$ de cal. Contudo, de 28 para 84 dias, a taxa de aumento das misturas de solo-cinza-cal foi maior do que a da mistura solo-cal, isto é, as reações pozolânicas foram mais efetivas ao longo do tempo nas misturas que continham cinza pesada.

\subsubsection{2 - Comparação da resistência à compressão simples e módulo tangente Inicial}

A partir dos valores médios de resistência à compressão simples e módulo tangente inicial pôde-se estabelecer uma relação entre estes dois parâmetros, expressa pelas equações 4.1 e 4.2 , para as misturas solo-cinza e solo-cinza-cal, respectivamente. As figuras 4.13 e 4.14 apresentam, graficamente, essas relações entre a resistência à compressão simples e o módulo tangente inicial para as misturas solo-cinza e solo-cinza-cal, respectivamente.

Para misturas de solo-cinza:

$$
\mathrm{RCS}=8,6005 \mathrm{E}_{0}+253,78
$$


Para misturas de solo-cinza-cal:

$$
\mathrm{RCS}=7,8466 \mathrm{E}_{0}+528,51
$$

Onde:

RCS: resistência à compressão simples $(\mathrm{kPa})$;

$\mathrm{E}_{0}$ : módulo tangente inicial (MPa).

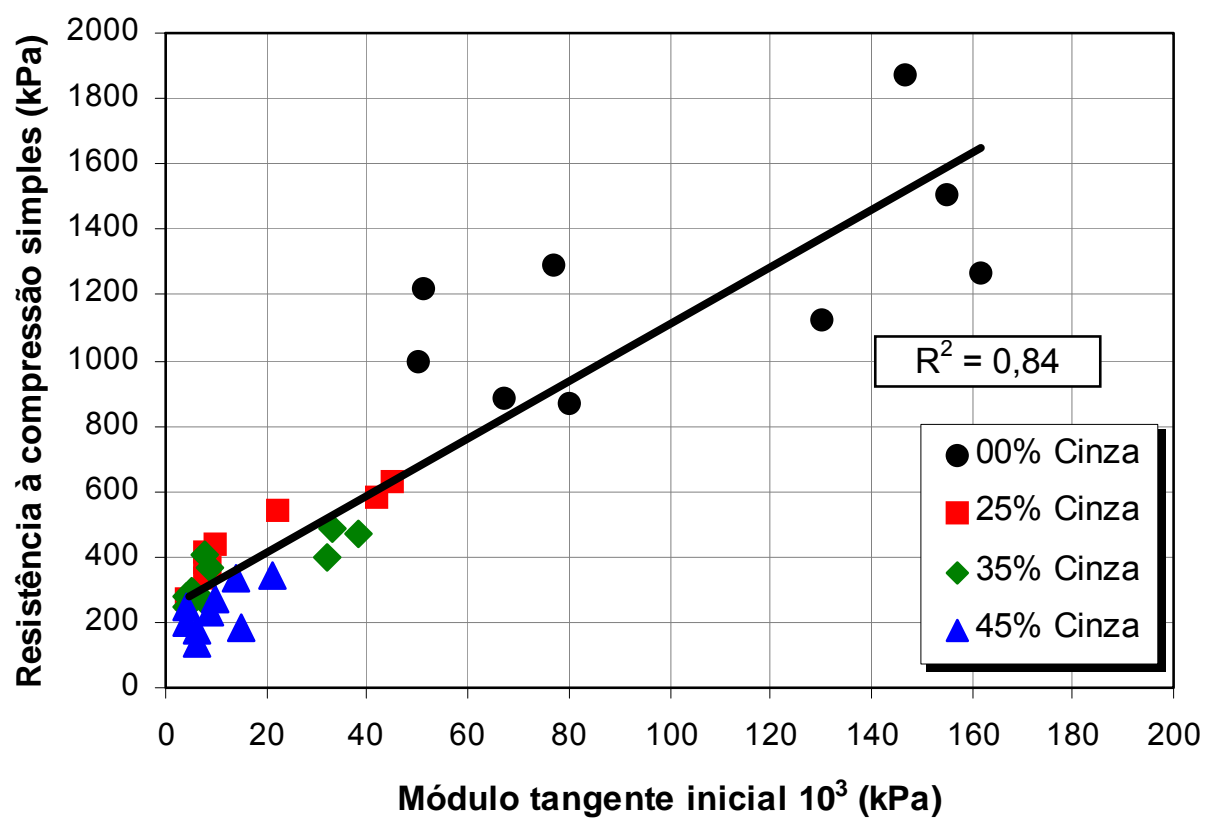

FIGURA 4.13 - Resistência à compressão simples versus módulo tangente inicial das misturas de solo-cinza.

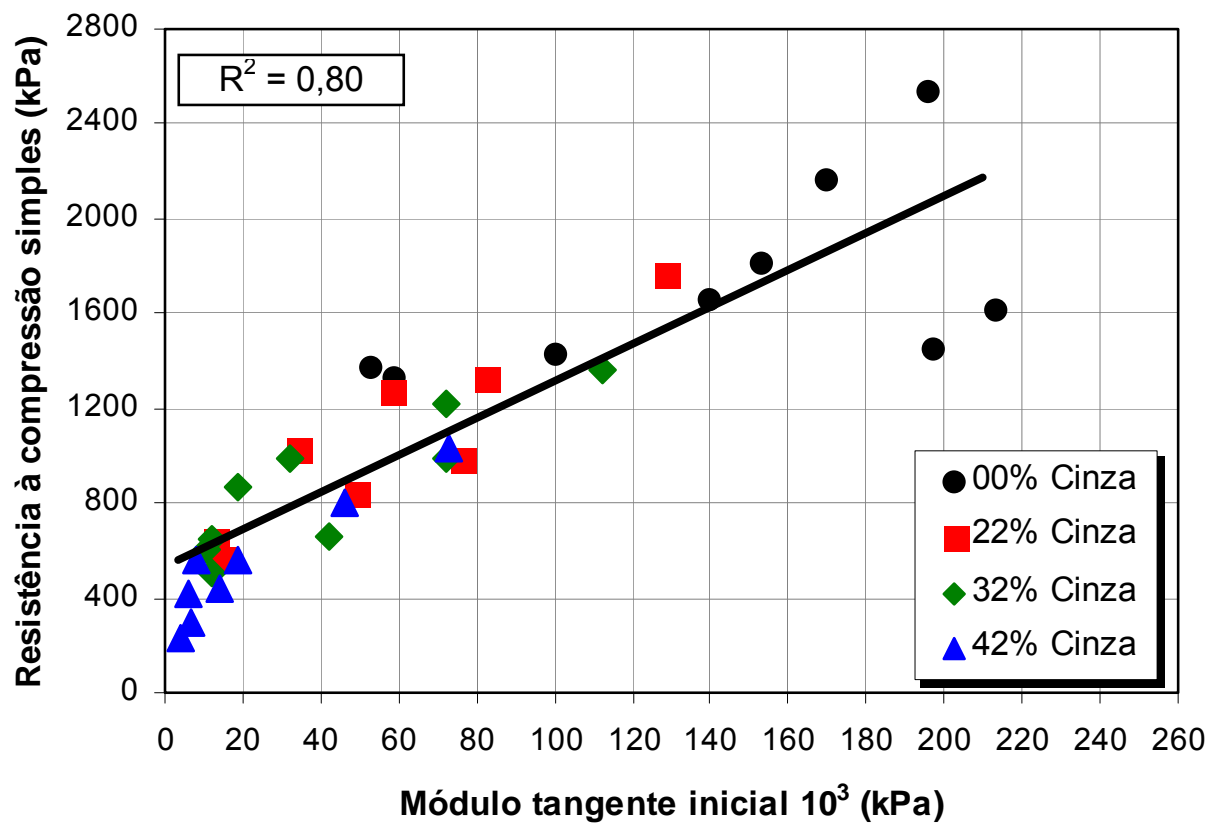

FIGURA 4.14 - Resistência à compressão simples versus módulo tangente inicial das misturas de solo-cinza-cal. 
Através das figuras 4.13 e 4.14 , percebe-se que geralmente maiores teores de cinza conduzem à redução do módulo tangente inicial e também da resistência à compressão simples, tanto para as misturas de solo-cinza-cal quanto para as misturas de solo-cinza. Nota-se, também, que existe uma relação linear bem definida entre a resistência à compressão simples e o módulo tangente inicial para as misturas de solo-cinza e solo-cinza-cal com coeficientes de determinação de 0,84 e 0,80, respectivamente. É importante observar que os modelos representados pelas expressões 4.1 e 4.2 foram obtidos através dos gráficos das figura 4.13 e 4.14 com o propósito de se ter uma previsão de módulo tangente inicial à partir da resistência à compressão simples. Dessa forma, os modelos que melhor representaram essa relação $\left(R^{2}\right.$ maior) foram os que tiveram a linha de tendência deslocada do ponto de origem dos gráficos (ponto 0,0 ).

Os gráficos de barras das figuras 4.15, 4.16 e 4.17 apresentam as variações percentuais nos valores médios de resistência à compressão simples e módulo tangente inicial das misturas de solo-cinza devido à adição de $3 \%$ de cal para os três períodos de cura adotados: 0,28 e 84 dias, respectivamente.

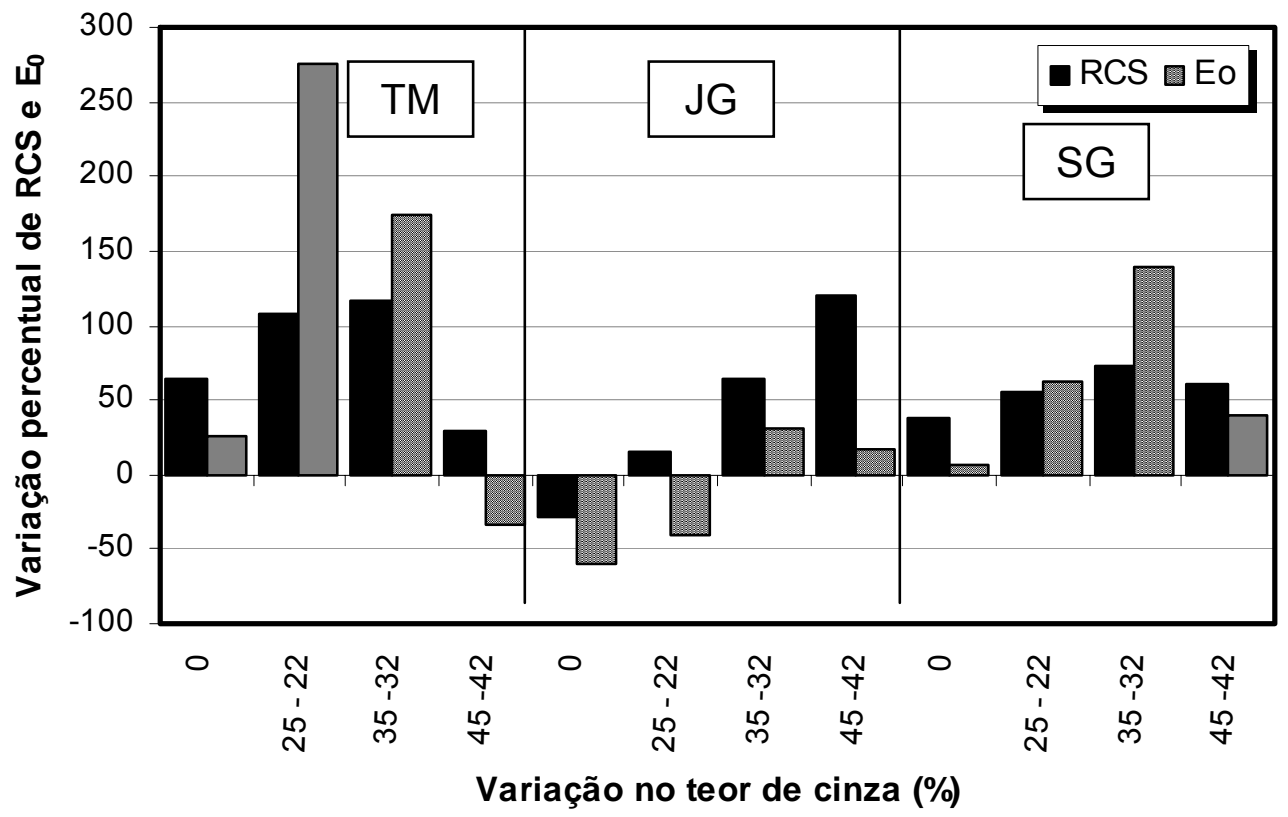

FIGURA 4.15 - Variação percentual das resistências à compressão simples e módulo tangente inicial das misturas de solo-cinza devido à adição de $3 \%$ de cal sem cura prévia. 


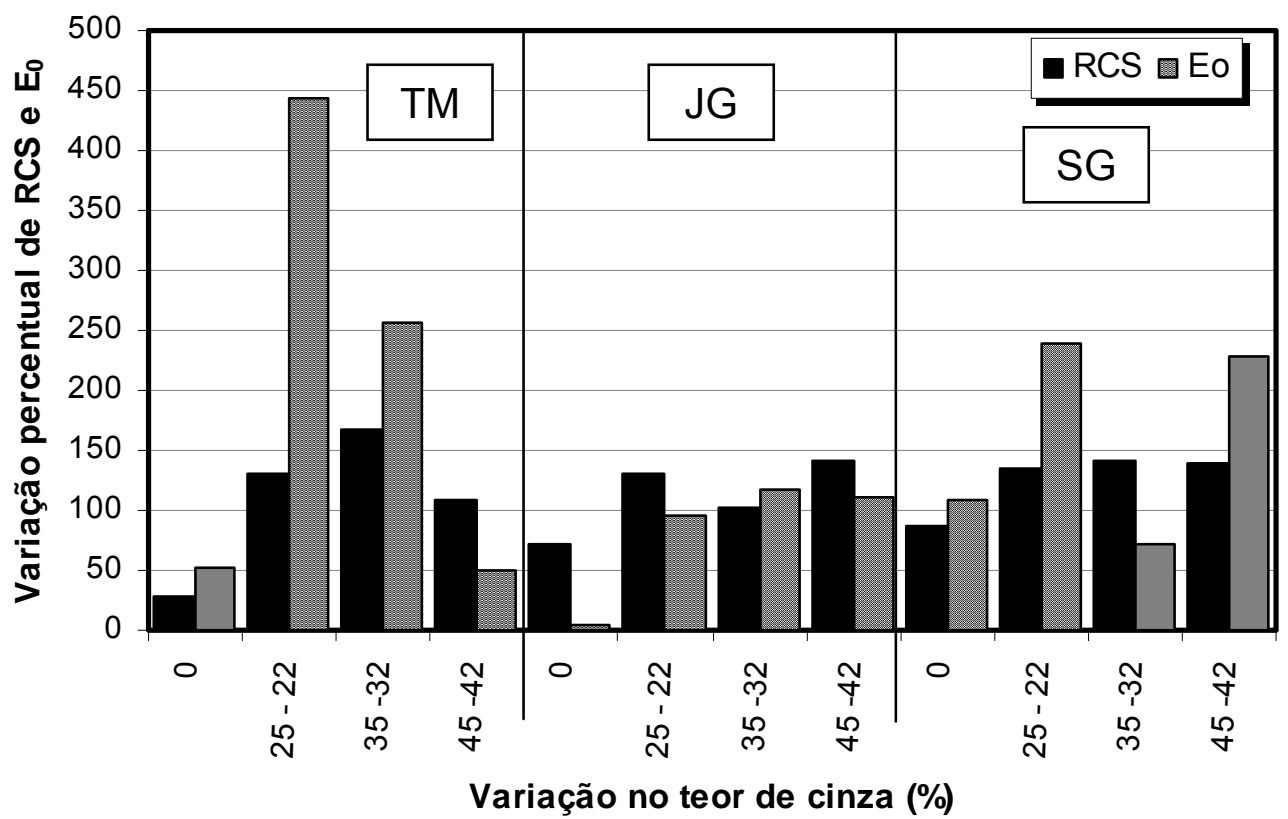

FIGURA 4.16 - Variação percentual das resistências à compressão simples e módulo tangente inicial das misturas de solo-cinza devido à adição de $3 \%$ de cal aos 28 dias de cura.

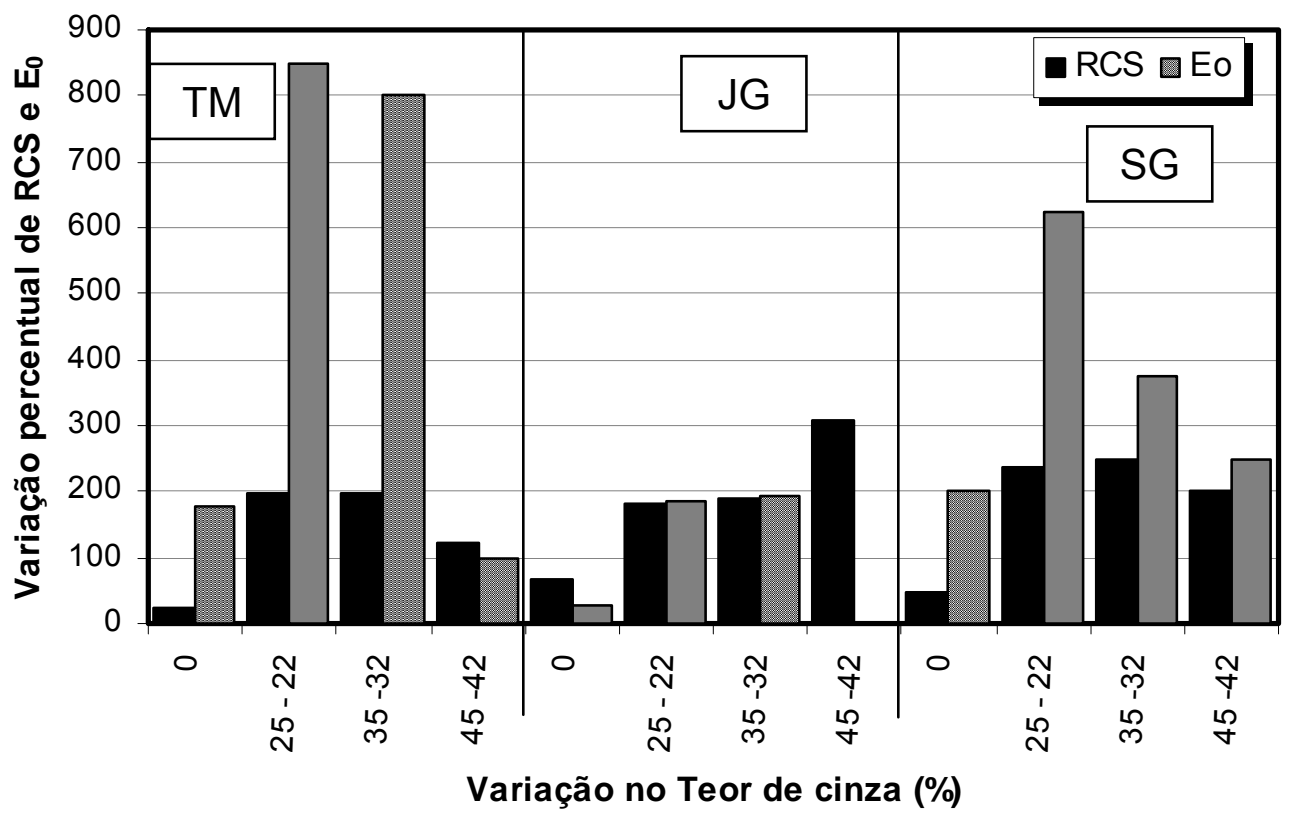

FIGURA 4.17 - Variação percentual das resistências à compressão simples e módulo tangente inicial das misturas de solo-cinza devido à adição de 3\% de cal aos 84 dias de cura.

Analisando-se as figuras 4.15, 4.16 e 4.17, observa-se que normalmente as variações de módulo tangente inicial foram significativamente maiores do que as variações de resistência à compressão simples após a adição de cal às misturas dos solos não lateríticos com cinza pesada, principalmente para as misturas com zero, 22 e $32 \%$ de cinza. 
Com respeito às misturas do solo laterítico com cinza, nota-se que após a adição de cal as variações de resistência à compressão simples foram, na maioria das vezes, maiores do que as variações positivas de módulo tangente inicial, principalmente para as misturas que continham 0, 22 e $42 \%$ de cinza pesada.

Desse modo, nota-se que o efeito da adição de cal é mais notável no módulo tangente inicial para as misturas com solos não lateríticos-cinza e que, nas misturas com solo laterítico-cinza o seu efeito é maior na resistência à compressão simples.

Outra característica do comportamento das misturas dos três solos com cinza e cal que pode ser observada através das figuras 4.15, 4.16 e 4.17, é que para os três períodos de cura, as variações positivas, tanto de resistência à compressão simples quanto de módulo tangente inicial, são, na maior parte das vezes, maiores para as misturas de solo-cinza-cal do que para as misturas de solo-cal. Portanto, a cal atua de maneira mais efetiva sobre as misturas contendo cinza pesada do que nos solos puros. Esse comportamento se deve ao fato de que as reações entre a cinza e a cal produzem novos compostos cimentantes que contribuem para a elevação da resistência à compressão simples e, também, do módulo tangente inicial.

\subsection{3 - Resistência à Tração por Compressão Diametral}

Geralmente, camadas estabilizadas com cal apresentam elevada resistência e rigidez, que fazem com que seu comportamento seja semelhante ao de uma placa, contribuindo na redução das tensões transmitidas às camadas subjacentes. Porém, podem aparecer nestas camadas tensões de flexão consideráveis, o que justifica a análise do comportamento à tração das misturas com cal.

O ensaio de compressão diametral tem sido utilizado por muitos autores para determinar a resistência à tração de misturas de solo-cal. Aqui serão 
apresentados e discutidos os resultados obtidos através dos ensaios de compressão diametral para as misturas de solo-cinza e solo-cinza-cal.

Os valores médios de resistência à tração por compressão diametral dos solos, das misturas de solo-cinza e de solo-cinza-cal, para todos os períodos de cura, estão apresentados na tabela 4.4.

TABELA 4.4 - Resistência à tração por compressão diametral dos solos e das misturas de solo-cal, solo-cinza e solo-cinza-cal para todos os períodos de cura.

\begin{tabular}{|c|c|c|c|c|c|c|c|}
\hline \multirow{4}{*}{ Solo } & \multirow{4}{*}{$\begin{array}{c}\text { Teor de } \\
\text { Cinza } \\
(\%)\end{array}$} & \multicolumn{6}{|c|}{ Resistência à Tração por Compressão Diametral (kPa) } \\
\hline & & \multicolumn{6}{|c|}{ Período de Cura (dias) } \\
\hline & & \multicolumn{2}{|c|}{0} & \multicolumn{2}{|c|}{28} & \multicolumn{2}{|c|}{84} \\
\hline & & Sem Cal & Com Cal & Sem Cal & Com Cal & Sem Cal & Com Cal \\
\hline \multirow{4}{*}{$\mathrm{TM}$} & 0 & 122 & 185 & 97 & 157 & 94 & 140 \\
\hline & 25 & 15 & 45 & 13 & 61 & 12 & 70 \\
\hline & 35 & 22 & 51 & 16 & 59 & 32 & 67 \\
\hline & 45 & 13 & 15 & 11 & 20 & 11 & 30 \\
\hline \multirow{4}{*}{ JG } & 0 & 173 & 234 & 140 & 198 & 118 & 161 \\
\hline & 25 & 77 & 75 & 43 & 103 & 33 & 132 \\
\hline & 35 & 37 & 49 & 25 & 72 & 20 & 102 \\
\hline & 45 & 10 & 24 & 22 & 12 & 22 & - \\
\hline \multirow{4}{*}{ SG } & 0 & 82 & 161 & 72 & 150 & 70 & 145 \\
\hline & 25 & 28 & 51 & 47 & 64 & 54 & 80 \\
\hline & 35 & 19 & 31 & 26 & 44 & 32 & 58 \\
\hline & 45 & 12 & 14 & 10 & 52 & 10 & 61 \\
\hline
\end{tabular}

* Para as misturas com cal o teor de cinza é reduzido em $3 \%$.

As adições de cinza pesada aos solos provocaram a diminuição das resistências à tração por compressão diametral conforme pode ser observado na tabela 4.4. Normalmente, quanto maior a quantidade de cinza misturada aos solos menor foi o valor de resistência à tração observado.

O solo SG foi o que apresentou menor perda de resistência à tração após a adição de $25 \%$ de cinza pesada para 28 e 84 dias de cura, 34 e $22 \%$, respectivamente. Já o solo laterítico JG apresentou redução de resistência à tração por compressão diametral entre 58 e $71 \%$ para 25\% de cinza. Para as misturas do solo TM com o mesmo teor de cinza as reduções de resistência à tração foram maiores que $80 \%$ para todos os períodos de cura. 
A figura 4.18 ilustra a variação da resistência à tração por compressão diametral das misturas solo-cinza em função do teor de cinza pesada aos 28 dias de cura.

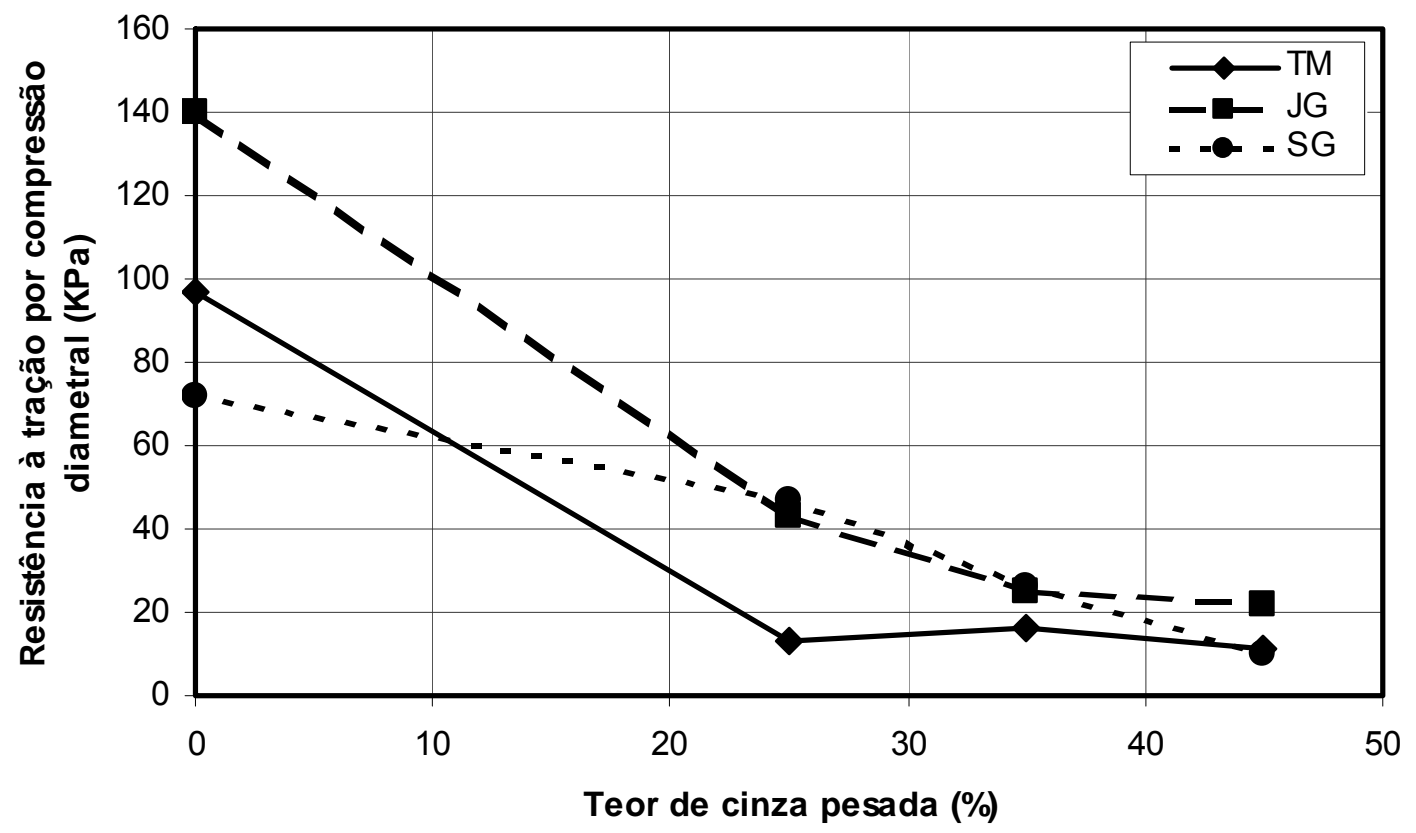

FIGURA 4.18 - Resistência à tração por compressão diametral das misturas de solo-cinza em função do teor de cinza aos 28 dias de cura.

$\mathrm{Na}$ figura 4.18, verifica-se que o solo laterítico puro apresentou maior resistência à tração por compressão diametral e que após a adição de $25 \%$ de cinza pesada o solo não laterítico SG foi o que apresentou menor redução de resistência. A partir da adição de $35 \%$ de cinza pesada aos solos percebe-se que as resistências à tração são semelhantes.

Analisando-se a influência da cura nas resistências à tração por compressão diametral das misturas solo-cinza, apresentadas na tabela 4.4, nota-se que todos os solos puros apresentaram diminuição de resistência à tração ao longo do tempo de cura. As misturas que apresentaram ganhos mais significativos de resistência à tração por compressão diametral ao longo do período de cura foram as misturas do solo não laterítico SG com 25 e 35\% de cinza e a mistura do solo laterítico JG com $45 \%$ de cinza pesada. Para as duas primeiras misturas $\left(\mathrm{SGA}_{25}\right.$ e $\left.\mathrm{SGA}_{35}\right)$, os ganhos foram de 93 e $70 \%$ aos 84 dias, enquanto que para a mistura $\mathrm{JGA}_{45}$ com o mesmo tempo de cura o ganho foi de $117 \%$, aproximadamente. 
As figuras 4.19 e 4.20 mostram a variação da resistência à tração das misturas do solo laterítico JG com cinza pesada e do solo não laterítico SG em função do período de cura, respectivamente.

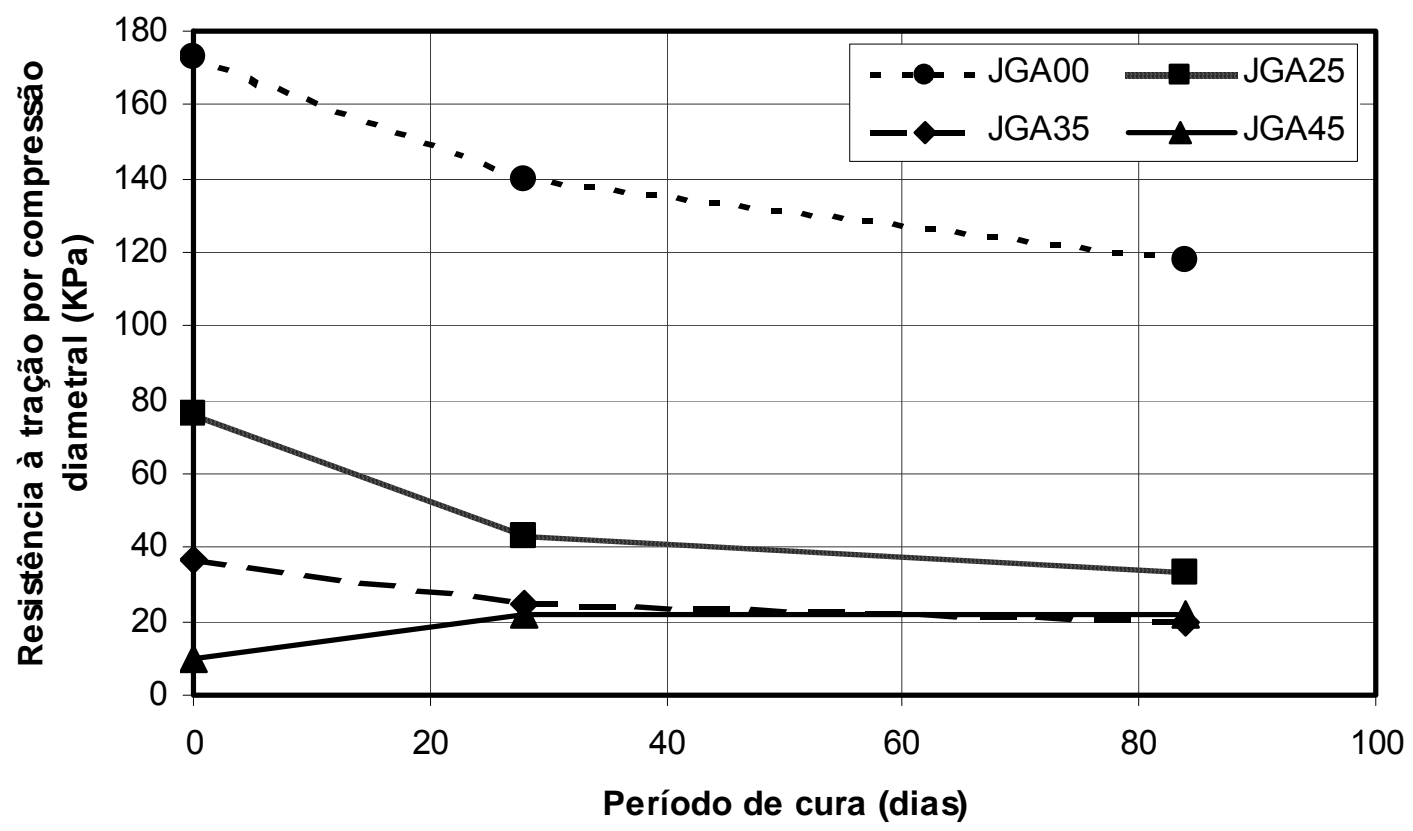

FIGURA 4.19 - Resistência à tração por compressão diametral das misturas do solo laterítico JG com cinza pesada em função do período de cura.

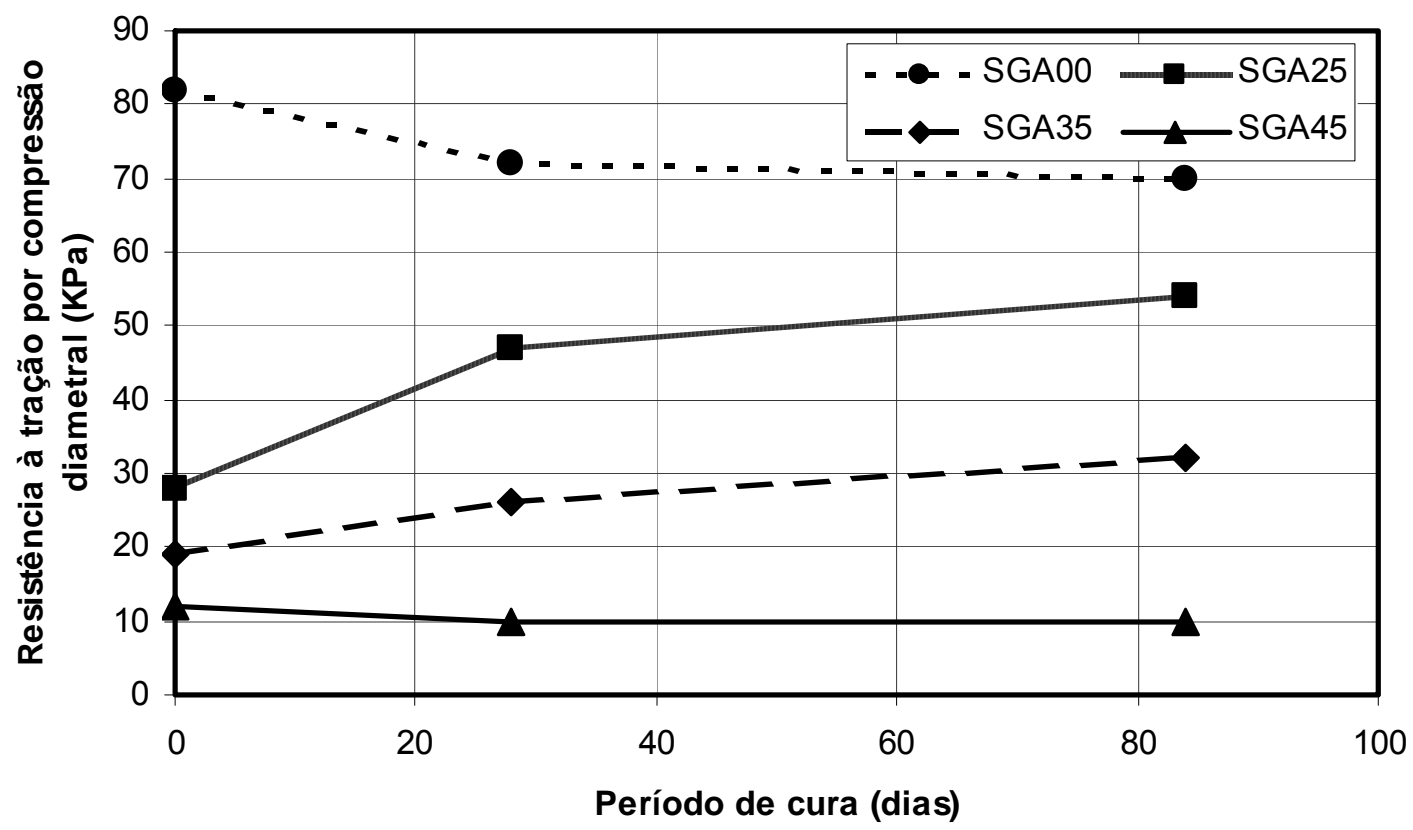

FIGURA 4.20 - Resistência à tração por compressão diametral das misturas do solo não laterítico SG com cinza pesada em função do período de cura. 
Analisando-se as figura 4.19 e 4.20 observa-se que as resistências à tração por compressão diametral das misturas do solo JG com 25 e 35\% de cinza pesada e para a mistura $\mathrm{SGA}_{45}$ diminuíram ao longo do período de cura, ou seja, as adições de cinza pesada não desencadearam nenhum tipo de reação que proporcionasse o aumento das resistências à tração por compressão diametral ao longo do tempo para esses teores de cinza.

Entretanto, a mistura do solo JG com $45 \%$ de cinza apresentou aumento relativo considerável de resistência à tração de zero pra 28 dias de cura. 0 mesmo ocorreu para as misturas do solo não laterítico SG com 25 e 35\% de cinza pesada. Porém, enquanto a resistência à tração da mistura do solo JG com $45 \%$ de cinza permaneceu praticamente constante após 28 dias de cura, as misturas do solo não laterítico SG com 25 e 35\% cinza pesada apresentaram ganhos significativos de um período de cura para outro, até aos 84 dias. Essa melhora de comportamento quanto à resistência à tração por compressão diametral pode indicar a ocorrência de reações pozolânicas ao longo do tempo devido à adição de cinza pesada ao solo não laterítico SG.

A adição de cal às misturas solo-cinza foi extremamente importante.Todos os solos e, praticamente, todas as misturas de solo-cinza, para um mesmo teor, apresentaram aumentos consideráveis de resistência à tração por compressão diametral.

Geralmente os ganhos de resistência para as misturas de solo-cinza com cal foram bem maiores do que os ganhos dos solos puros com cal. Aos 84 dias de cura a adição de cal aos solos aumentou em até 100\% a resistência à tração enquanto que a adição do mesmo teor de cal às misturas de solo-cinza elevou, em alguns casos, em mais de $400 \%$ as resistências à tração por compressão diametral. Desse modo, pode-se dizer que houve reações mais efetivas nas misturas de solo-cinza após a adição da cal do que nos solos puros, ou seja, as reações ocorridas, que proporcionaram aumentos importantes das resistências à tração das misturas de solo-cinza, se devem, principalmente, às reações de cimentação ocorridas entre a cinza e a cal. 
As figuras 4.21 e 4.22 ilustram a influência da adição de cal na resistência à tração por compressão diametral das misturas de solo-cinza e dos solos puros para a condição sem cura e aos 84 dias de cura, respectivamente.

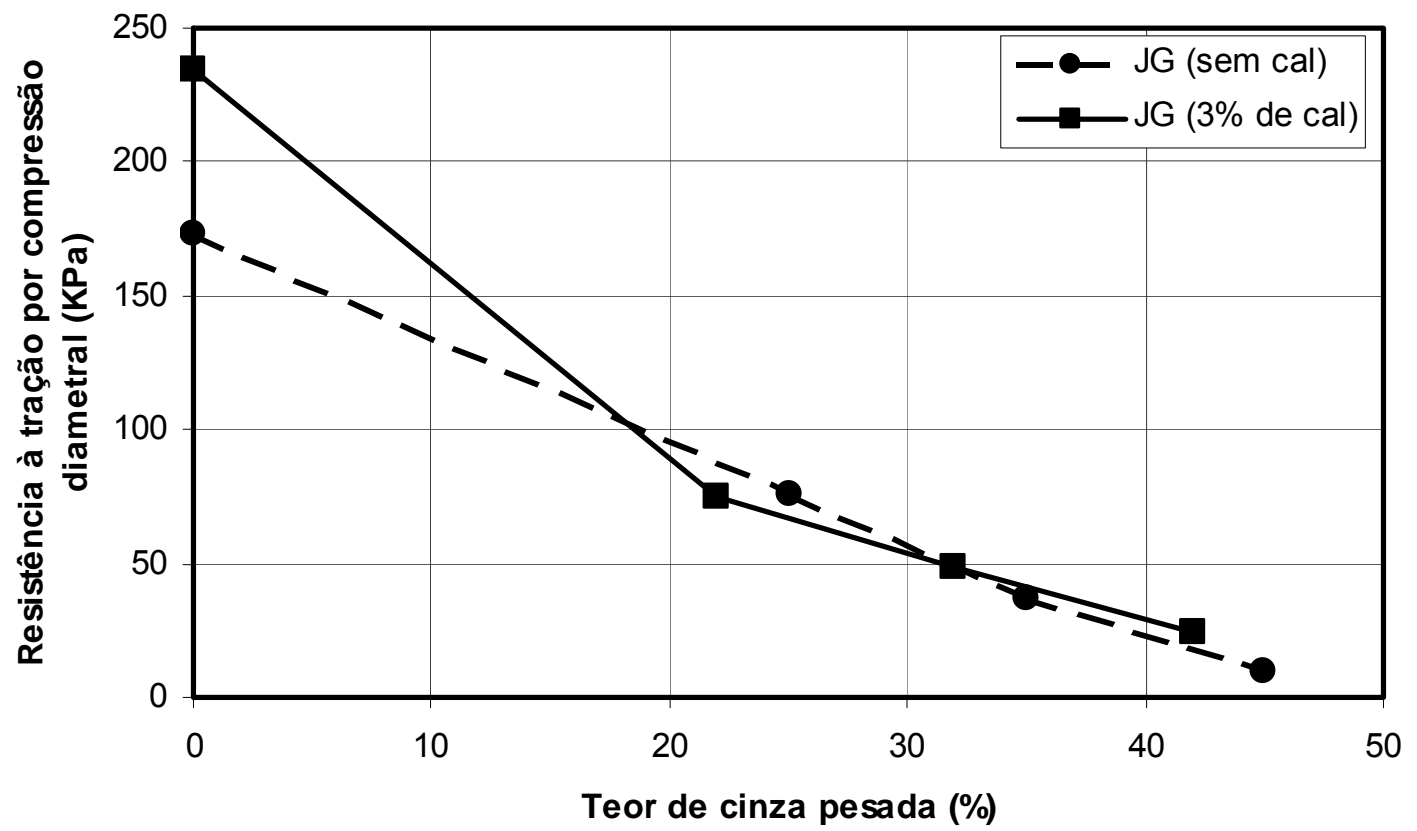

FIGURA 4.21 - Resistência à tração por compressão diametral das misturas do solo JG com cinza e cal e das misturas desse solo apenas com cinza na condição sem cura em função do teor de cinza pesada.

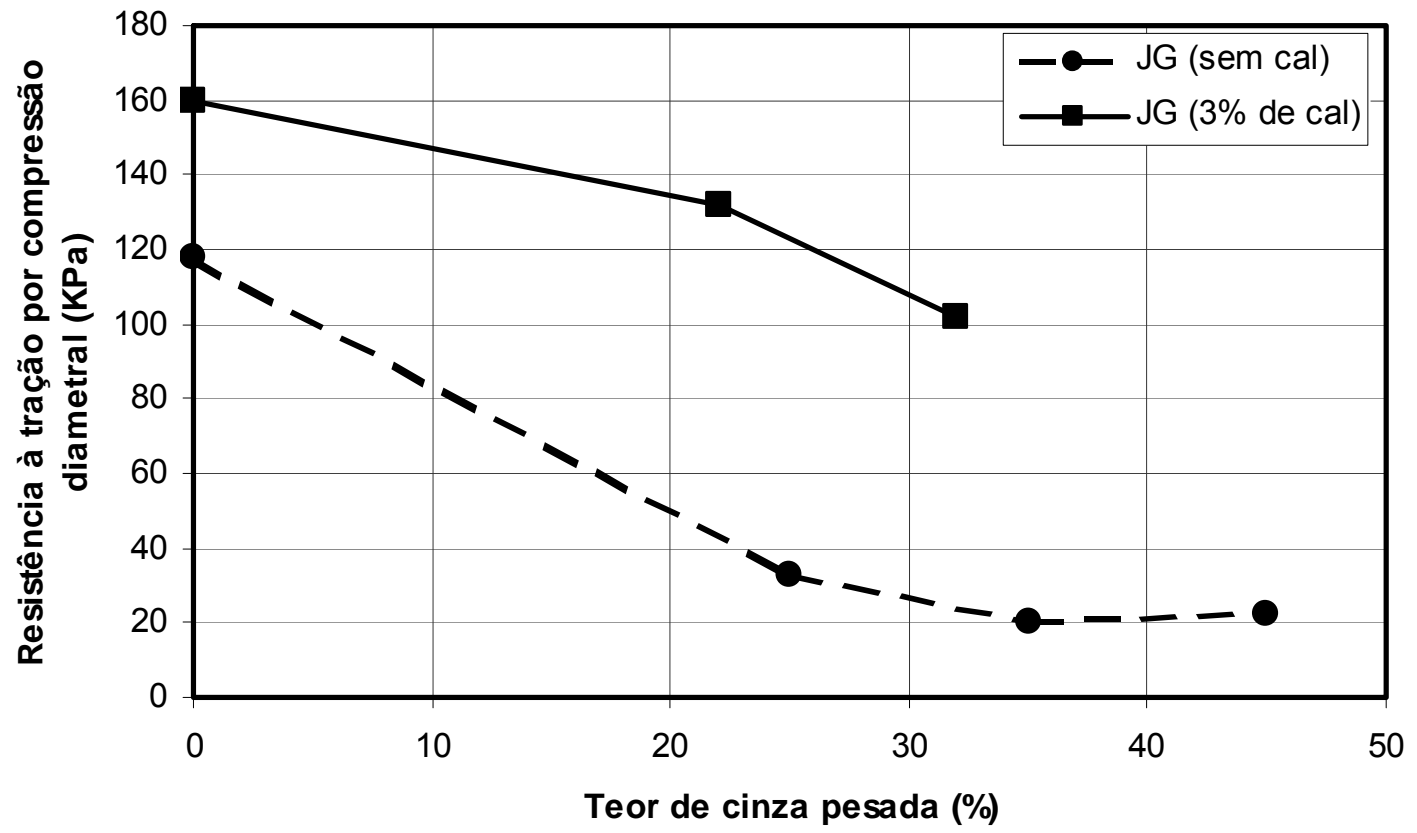

FIGURA 4.22 - Resistência à tração por compressão diametral das misturas do solo JG com cinza e cal e das misturas desse solo com apenas cinza aos 84 dias de cura em função do teor de cinza pesada. 
De acordo com as figuras 4.21 e 4.22, verifica-se que as resistências à tração por compressão diametral, tanto das misturas de solo-cinza quanto das misturas solo-cinza-cal, reduziram-se com o aumento no teor de cinza pesada. Esse comportamento foi observado para todos os três solos.

Através da observação da figura 4.21, nota-se que a adição de cal teve pouca influência sobre a resistência à tração imediata das misturas de solocinza. Para os outros solos não lateríticos ocorreu aumento significativo de resistência à tração por compressão diametral (tabela 4.4), ou seja, as misturas com solos não lateríticos com cinza pesada são mais sensíveis à influência imediata da adição de $3 \%$ de cal do que as misturas com solo laterítico.

Entretanto, aos 84 dias as misturas do solo laterítico com cinza pesada apresentaram aumentos de resistência à tração devido à adição da cal maior do que os solos não lateríticos (tabela 4.4), isto é, durante o decorrer do tempo as reações ocorridas nas misturas do solo JG com cinza e cal foram mais eficientes do que nas misturas dos solos não lateríticos.

Comparando-se os resultados apresentados nas figuras 4.21 e 4.22 , observa-se que aos 84 dias de cura as resistências à tração por compressão diametral das misturas solo-cinza-cal foram muito maiores do que as das misturas solo-cinza, diferentemente do que aconteceu na condição sem cura onde as resistências dos dois tipos de mistura foram semelhantes. Esse comportamento caracteriza a ocorrência de reações pozolânicas que ao longo do período de cura proporcionaram aumentos importantes de resistência à tração por compressão diametral. A figura 4.23 ilustra esse comportamento.

Através da figura 4.23 percebe-se que ao longo do período de cura a resistência do solo-cal diminuiu gradativamente enquanto que, as misturas solo-cinza-cal apresentaram aumentos expressivos de resistência à tração por compressão diametral ao longo do tempo, ou seja, ocorreram reações pozolânicas apenas nas misturas que continham cinza pesada. 


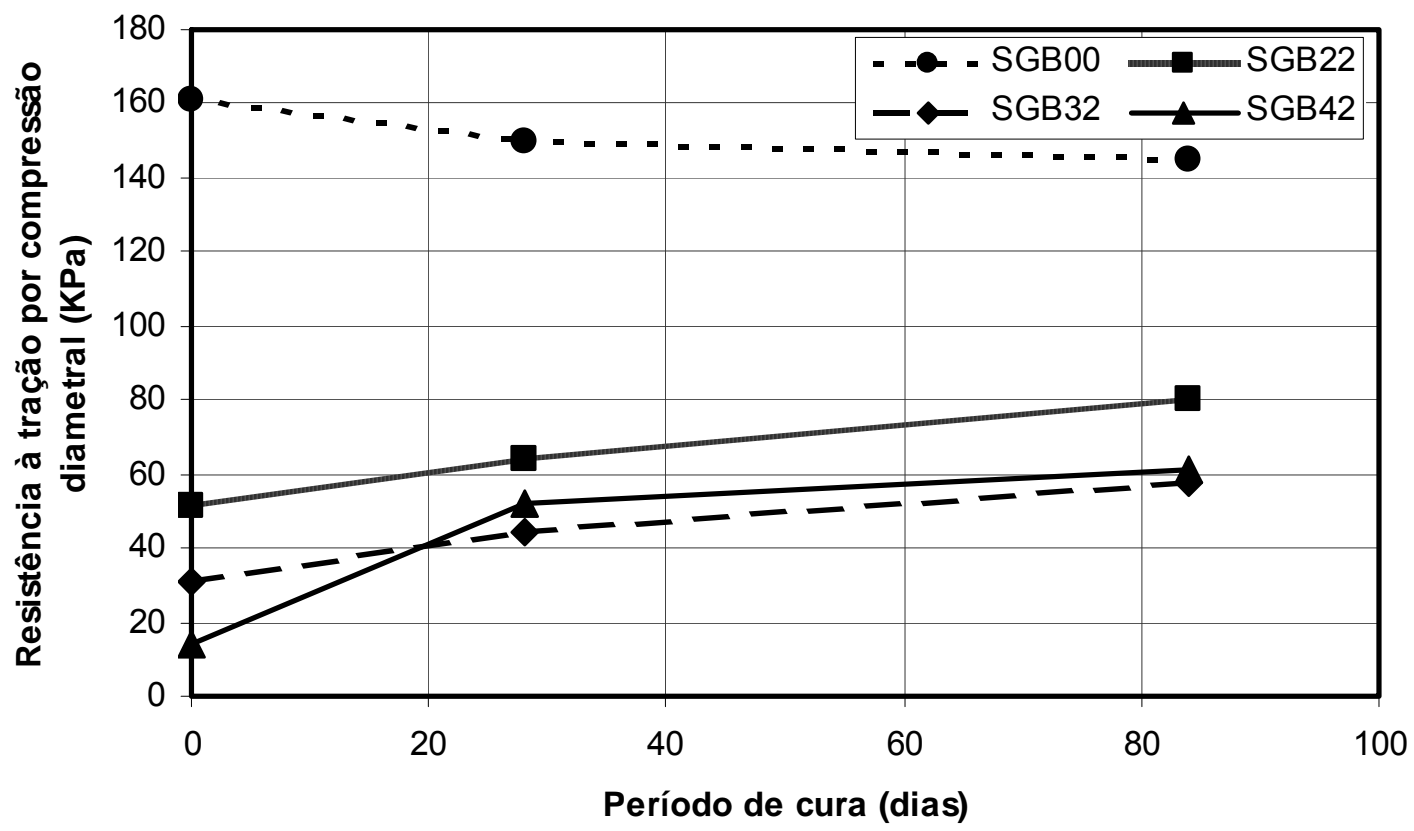

FIGURA 4.23 - Resistência à tração por compressão diametral das misturas do solo SG com cinza pesada e cal em função do período de cura.

\subsubsection{1 - Comparação das resistências à compressão simples e à tração} por compressão diametral

Os gráficos das figuras 4.24 e 4.25 apresentam os valores médios de resistência à compressão simples versus os valores médios de resistência à tração por compressão diametral para todos os períodos de cura de todas as misturas de solo-cinza e solo-cinza-cal, respectivamente. As equações $4.3 \mathrm{e}$ 4.4 expressam a relação entre RCS e RTCD (resistência à tração por compressão diametral) para as misturas de solo-cinza e solo-cinza-cal, respectivamente.

Para misturas de solo-cinza:

$$
\mathrm{RCS}=9,2695 \mathrm{RTCD}+141,19
$$

Para misturas de solo-cinza-cal:

$$
\mathrm{RCS}=7,8865 \mathrm{RTCD}+375,88
$$

Onde:

RCS: resistência à compressão simples $(\mathrm{KPa})$; 
RTCD: resistência à tração por compressão diametral $(\mathrm{KPa})$.

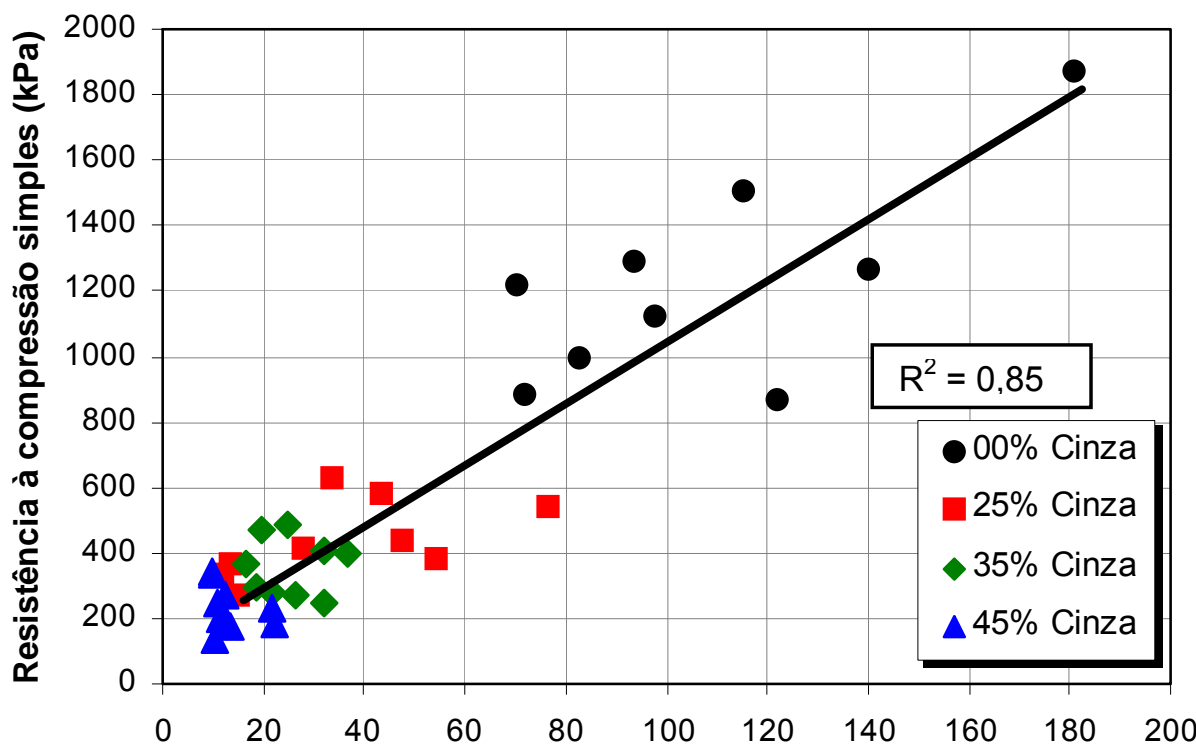

Resistência à tração por compressão diametral (kPa)

FIGURA 4.24 - Resistência à compressão simples versus resistência à tração por compressão diametral das misturas de solo-cinza.

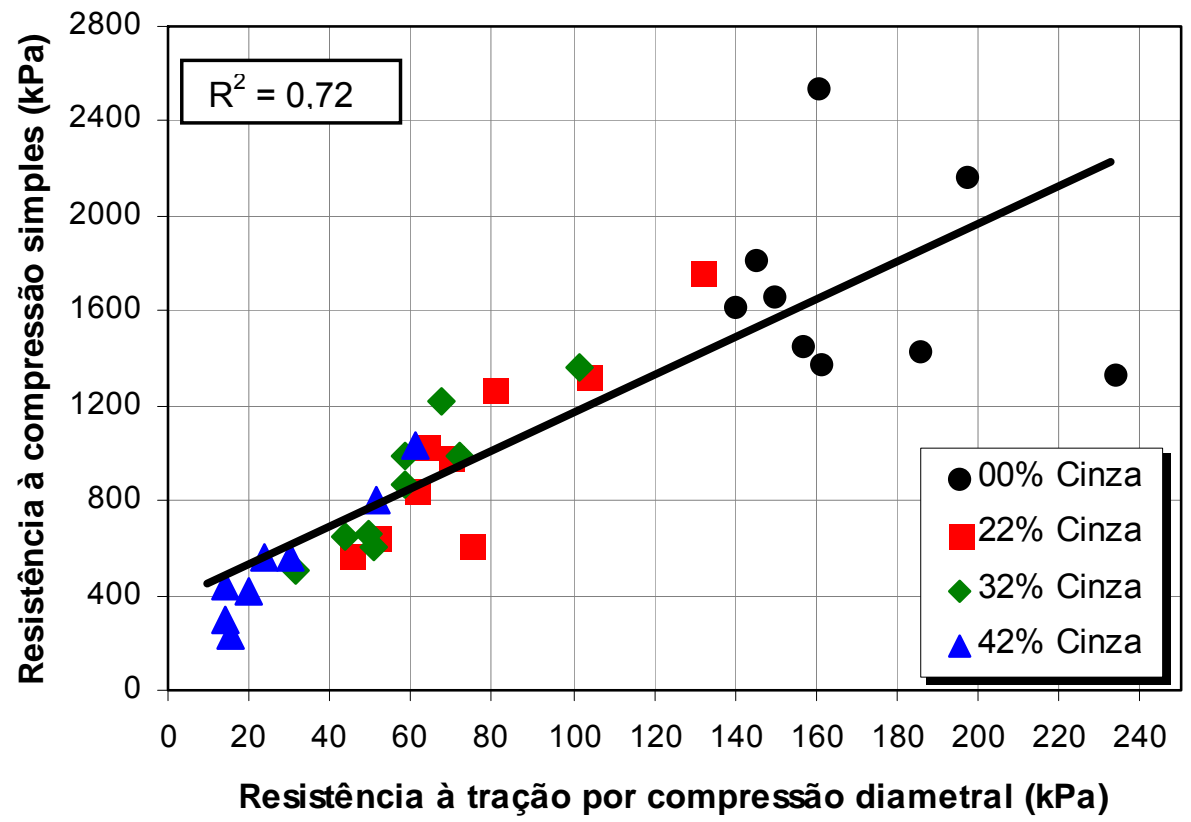

FIGURA 4.25 - Resistências à compressão simples versus resistência à tração por compressão diametral das misturas de solo-cinza-cal.

Da observação das figuras 4.24 e 4.25 verifica-se que para maiores teores de cinza pesada nas misturas, obtêm-se menores valores de resistência à compressão simples e, também, de resistência à tração por compressão diametral. Além disso, percebe-se que existe uma relação linear bem definida entre as resistências à compressão simples e à tração por compressão 
diametral, sendo que as misturas de solo-cinza apresentaram coeficiente de determinação maior do que o das misturas de solo-cinza-cal, que foram iguais a 0,85 e 0,72 , respectivamente. Vale ressaltar que os modelos que apresentaram melhores coeficientes de determinação foram os que tiveram a linha de tendência deslocada da origem, ou seja, as expressões 4.3 e 4.4 servem apenas como modelos de previsão de propriedade.

Os gráficos de barras das figuras 4.26, 4.27 e 4.28 apresentam as variações percentuais nos valores médios de resistência à compressão simples e à tração por compressão diametral das misturas de solo-cinza em relação à adição de $3 \%$ de cal para os três períodos de cura, respectivamente.

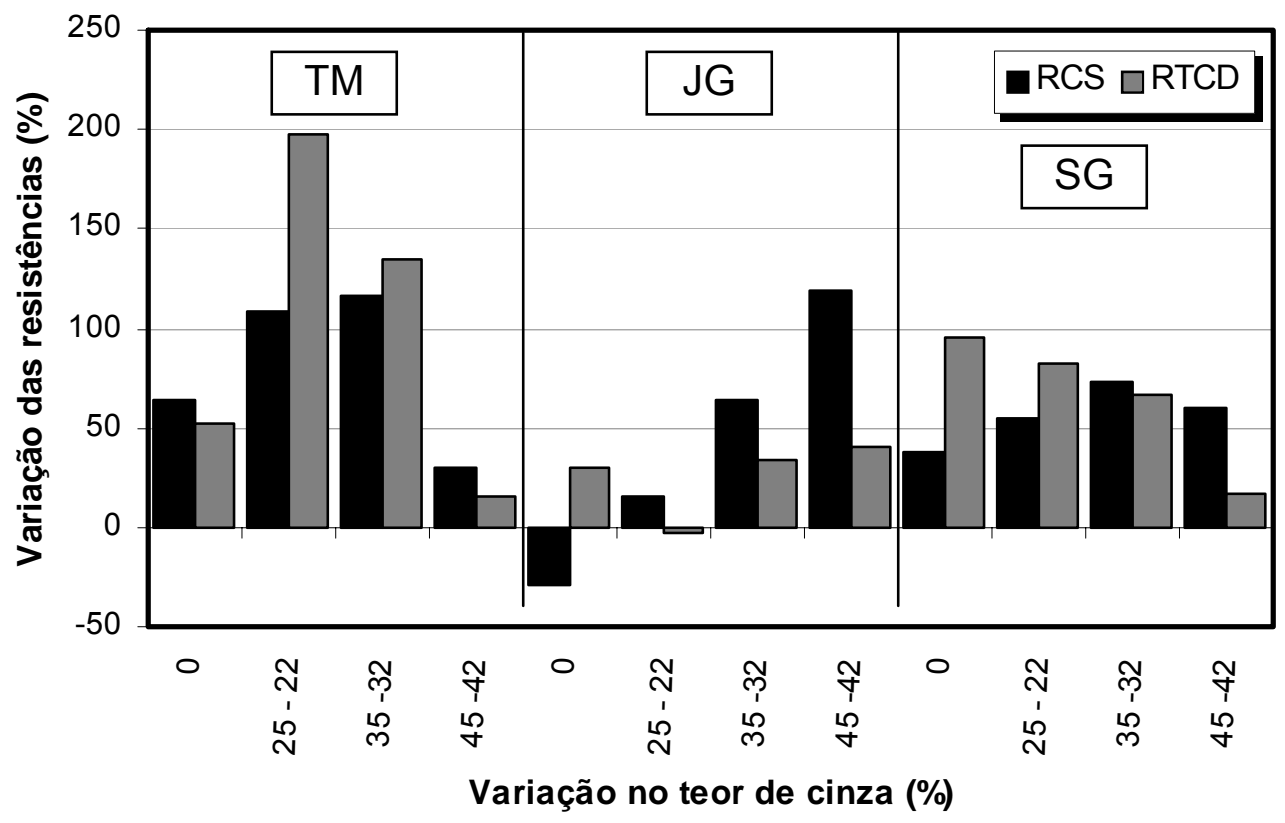

FIGURA 4.26 - Variação percentual das resistências à compressão simples e à tração por compressão diametral das misturas de solo-cinza devido à adição de $3 \%$ de cal sem cura prévia. 


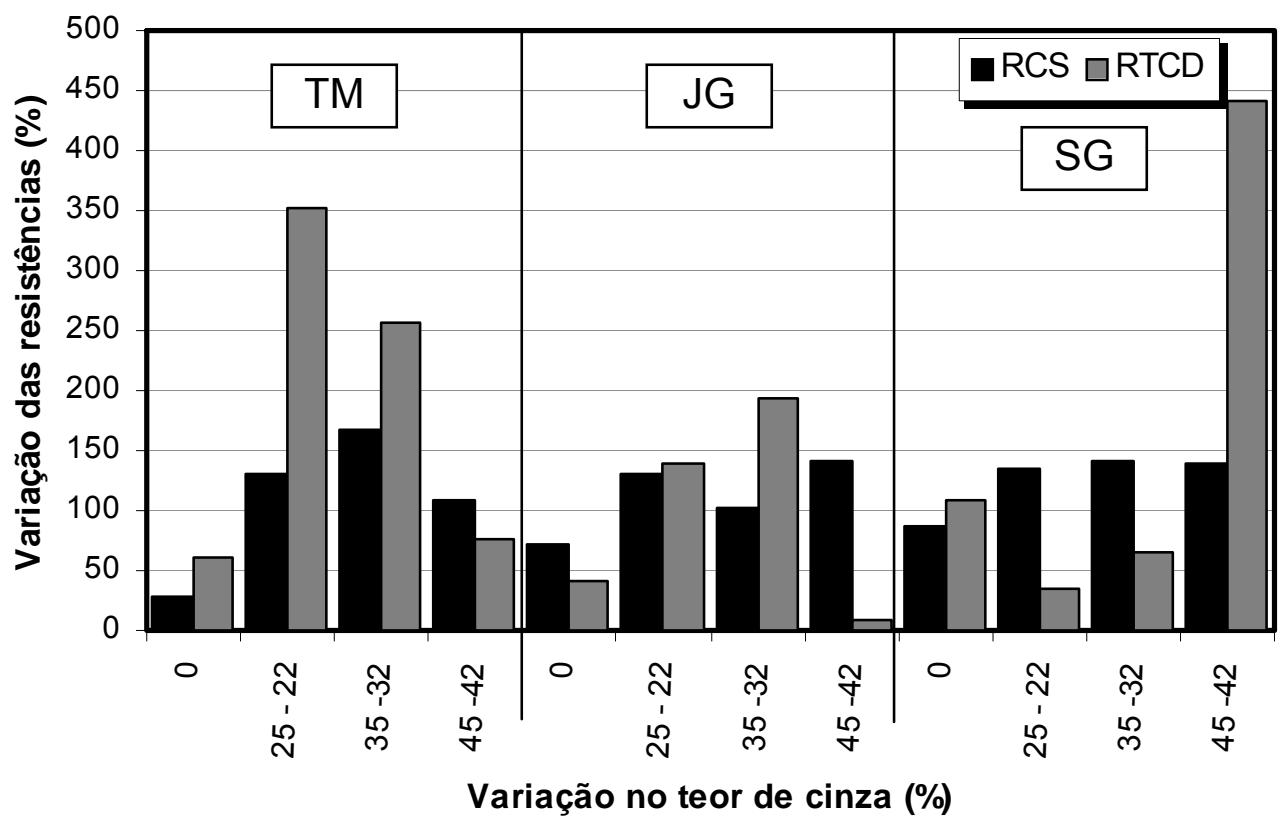

FIGURA 4.27 - Variação percentual das resistências à compressão simples e à tração por compressão diametral das misturas de solo-cinza devido à adição de $3 \%$ de cal aos 28 dias de cura.

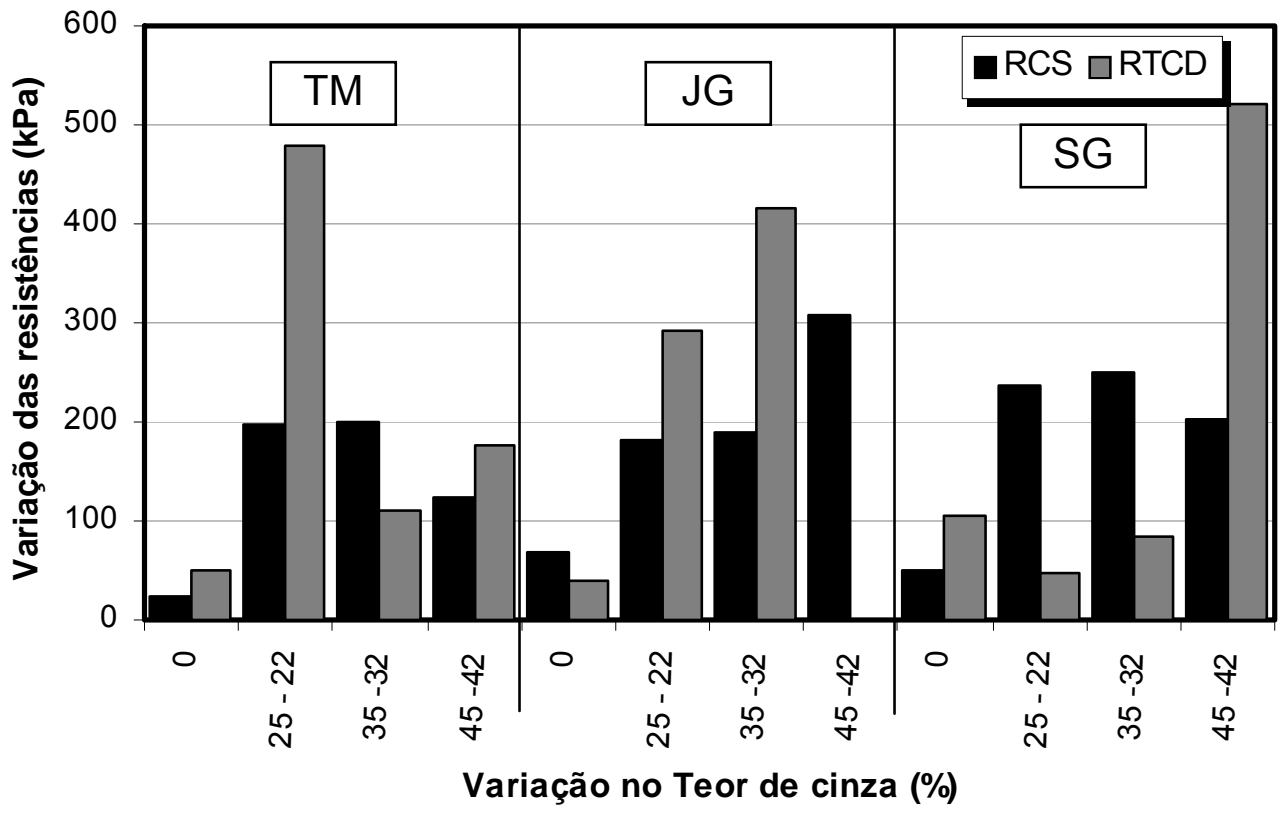

FIGURA 4.28 - Variação percentual das resistências à compressão simples e à tração por compressão diametral das misturas de solo-cinza devido à adição de $3 \%$ de cal aos 84 dias de cura.

Analisando-se as figuras 4.26, 4.27 e 4.28, nota-se que as variações das resistências à compressão simples e tração por compressão diametral, devido à adição de $3 \%$ de cal, são bem distintas quando comparadas entre si. 
Para as misturas do solo TM com cinza, verifica-se que a resistência à tração por compressão diametral foi mais sensível à adição de 3\% de cal para os teores de 22 e $32 \%$ de cinza pesada sem cura e aos 28 dias. Já aos 84 dias de cura a resistência à tração para os teores de 22 e $42 \%$ de cinza foram mais influenciados positivamente pela adição de cal.

A resistência à tração por compressão diametral para os teores de $22 \mathrm{e}$ $32 \%$ de cinza das misturas com o solo JG também foram mais sensíveis ao efeito positivo da adição de cal para 28 e 84 dias de cura. Assim, pode-se dizer que a adição de cal exerce, geralmente, maior influência positiva na resistência à tração por compressão diametral para os teores de 22 e $32 \%$ de cinza para os solos TM e JG, evidenciando o efeito cimentante entre a cinza e a cal.

As misturas do solo SG com cinza pesada sofreram, na maioria das vezes, maior variação percentual de resistência à tração por compressão diametral para a mistura sem cinza pesada e para o teor de $42 \%$ de cinza. Entretanto, a variação percentual de resistência à tração por compressão diametral em relação à resistência à compressão simples, após adição de cal, foi muito maior para as misturas com $42 \%$ de cinza do que para as misturas sem adição de cinza pesada, ou seja, a cal agiu com mais eficiência quando se tinha a presença da cinza.

\subsection{4 - Intercepto Coesivo e Ângulo de Atrito das Misturas Solo-Cinza e Solo-Cinza-Cal}

Com os resultados dos ensaios de resistência à compressão simples e de resistência à tração por compressão diametral foi possível traçar a envoltória de ruptura de Mohr Coulomb para as misturas de solo-cinza e solocinza-cal, conforme descrito no capítulo 3.

Para a análise dos resultados de intercepto coesivo e ângulo de atrito, deve-se ressaltar que para traçar a reta tangente utilizou-se apenas dois pontos e que a envoltória de ruptura deveria ser, na realidade, uma curva, ou seja, o ângulo de atrito varia ao longo dessa curva sendo maior para tensões 
menores. Entretanto, os valores de intercepto coesivo são coerentes, sendo um pouco menores do que os interceptos da envoltória curva.

A tabela 4.5 mostra os resultados de intercepto coesivo, obtidos graficamente a partir dos valores médios de resistência à compressão simples e à tração por compressão diametral, dos solos puros e das misturas de solocal, solo-cinza e solo-cinza-cal para todos os períodos de cura.

TABELA 4.5 - Intercepto coesivo dos solos e das misturas de solo-cal, solo-cinza e solo-cinza-cal para todos os períodos de cura.

\begin{tabular}{|c|c|c|c|c|c|c|c|}
\hline \multirow{4}{*}{ Solo } & \multirow{3}{*}{$\begin{array}{c}\text { Teor de } \\
\text { Cinza } \\
(\%)\end{array}$} & \multicolumn{6}{|c|}{ Intercepto Coesivo (kPa) } \\
\cline { 3 - 8 } & & \multicolumn{7}{|c|}{ Período de Cura (dias) } \\
\cline { 2 - 8 } & & Sem Cal & Com Cal & Sem Cal & Com Cal & Sem Cal & Com Cal \\
\hline \multirow{4}{*}{ TM } & 0 & 213 & 330 & 193 & 290 & 191 & 277 \\
\cline { 2 - 8 } & 25 & 33 & 90 & 31 & 126 & 28 & 144 \\
\cline { 2 - 8 } & 35 & 44 & 99 & 37 & 130 & 64 & 155 \\
\cline { 2 - 8 } & 45 & 27 & 32 & 25 & 49 & 25 & 70 \\
\hline \multirow{4}{*}{ JG } & 0 & 345 & 421 & 256 & 382 & 237 & 357 \\
\cline { 2 - 8 } & 25 & 134 & 133 & 90 & 206 & 79 & 273 \\
\cline { 2 - 8 } & 35 & 66 & 102 & 59 & 146 & 51 & 205 \\
\cline { 2 - 8 } & 45 & 21 & 31 & 42 & 60 & 40 & - \\
\hline \multirow{4}{*}{ SG } & 0 & 164 & 291 & 144 & 295 & 157 & 291 \\
\cline { 2 - 8 } & 25 & 61 & 102 & 86 & 136 & 95 & 172 \\
\cline { 2 - 8 } & 35 & 40 & 70 & 49 & 95 & 57 & 122 \\
\cline { 2 - 8 } & 45 & 28 & 40 & 23 & 114 & 23 & 133 \\
\hline
\end{tabular}

* Para as misturas com cal o teor de cinza é reduzido em $3 \%$.

Através da análise da tabela 4.5 constata-se que as adições crescentes de cinza pesada influíram negativamente nos valores de intercepto coesivo dos solos estudados para todos os períodos de cura, ou seja, na maioria das vezes, o intercepto coesivo foi menor para as misturas com maior quantidade de cinza pesada. Esse comportamento foi verificado tanto para as misturas de solocinza quanto para as misturas solo-cinza-cal.

A diminuição dos valores de intercepto coesivo para teores crescentes de cinza se deve, provavelmente, ao seu caráter granular. Na maioria dos casos a redução no intercepto coesivo foi superior a $50 \%$ em relação ao solo puro para as misturas solo-cinza e ao solo-cal para as misturas solos-cinza-cal, sendo que, em alguns casos ocorreram reduções superiores a $85 \%$. 
Entretanto, as adições de cal aos solos e às misturas solo-cinza elevaram de maneira significativa os valores de intercepto coesivo, sendo que, as misturas do solo TM com cinza foram, geralmente, as que apresentaram maiores aumentos dos interceptos após a adição de cal que, em alguns casos, foram superiores a $400 \%$.

Analisando-se os valores de intercepto coesivo da tabela 4.5, após à adição de cal, nota-se que praticamente todas as misturas solo-cinza-cal apresentaram aumentos importantes em relação às misturas solo-cinza para um teor semelhante de cinza pesada. Assim, pode-se dizer que a adição de cal atuou de maneira positiva nas misturas solos-cinza, contribuindo para a melhora da coesão. Esse comportamento pode ser creditado às reações de cimentação ocorridas, principalmente, entre a cal e a cinza, uma vez que, na maior parte das situações, as misturas solo-cinza apresentaram aumentos dos interceptos coesivos, após a adição de cal, muito maiores do que os solos.

A figura 4.29 ilustra a variação, aos 84 dias de cura, do intercepto coesivo das misturas solo-cinza em função do teor de cinza pesada, para os três solos. Já a figura 4.30 mostra a variação típica do intercepto coesivo das misturas solo-cinza-cal em função do teor de cinza em comparação com os das misturas solo-cinza.

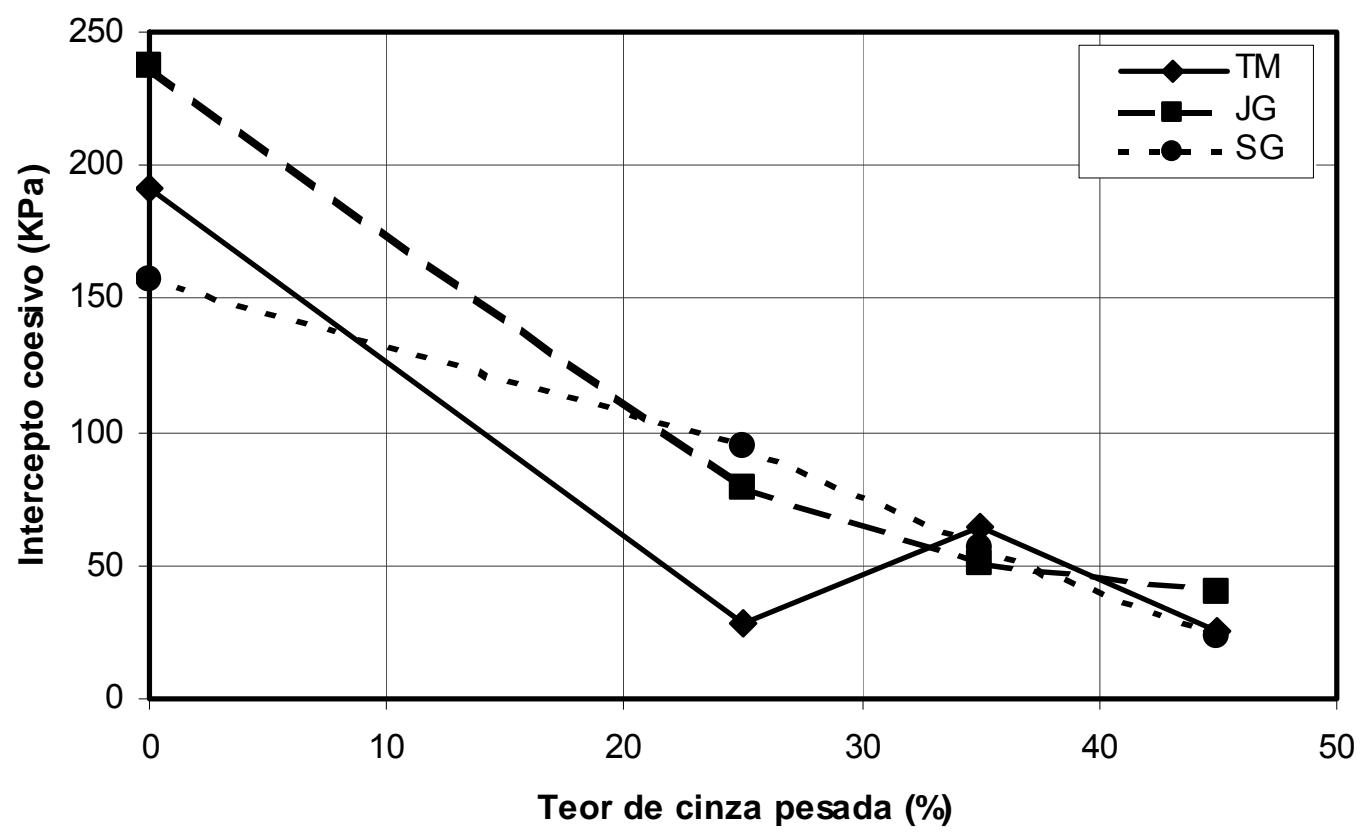

FIGURA 4.29 - Intercepto coesivo aos 84 dias de cura das misturas de solo-cinza em função do teor de cinza pesada. 


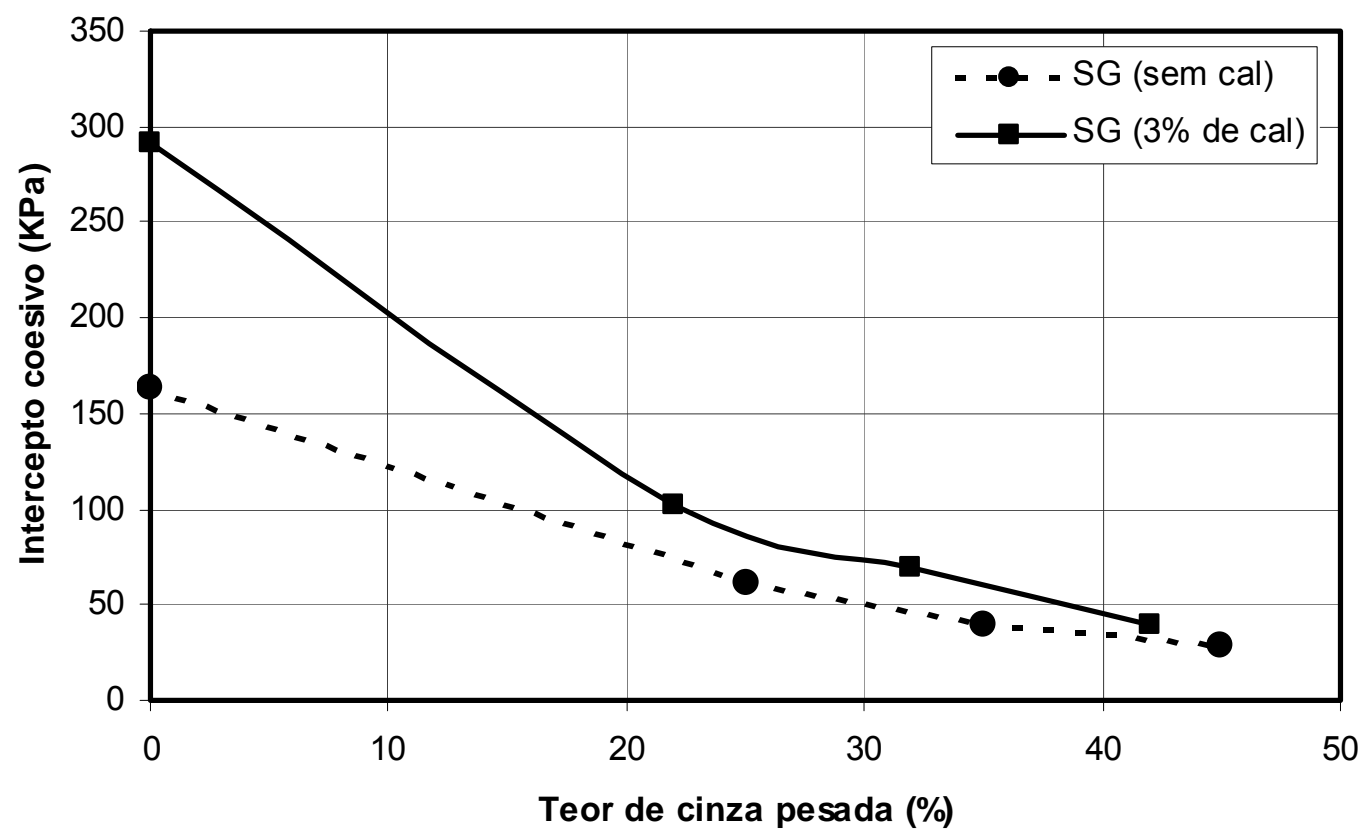

FIGURA 4.30 - Intercepto coesivo sem cura prévia das misturas do solo SG com cinza e cal em comparação com as misturas desse solo com apenas cinza pesada.

Nas figuras 4.29 e 4.30, verifica-se que as adições crescentes de cinza pesada aos solos e às misturas solo-cal ocasionaram reduções nos interceptos coesivos devido à granulometria típica de areia fina da cinza pesada. Contudo, a adição de $3 \%$ de cal elevou de maneira significativa os valores dos interceptos das misturas para um teor semelhante de cinza pesada, ou seja, a adição de cal proporcionou a melhora imediata do intercepto coesivo por meio da cimentação do material, contribuindo, dessa forma, para o aumento da coesão das misturas.

Entretanto, conforme pode ser observado na tabela 4.5, esse efeito foi mais importante ao longo do tempo de cura, isto é, com o passar do tempo ocorreram aumentos significativos de intercepto coesivo devido à adição de cal. Esse efeito foi mais pronunciado nas misturas que continham cinza pesada, ou seja, o aumento do intercepto coesivo após a adição de cal foi maior para as misturas solo-cinza do que para os solos puros. Isso caracteriza a ocorrência de reações pozolânicas entre a cinza e a cal que fizeram com que houvesse uma melhora no comportamento quanto à coesão dessas misturas ao longo do tempo. 
As figuras 4.31 e 4.32 apresentam as variações típica do intercepto coesivo das misturas de solo-cinza e solo-cinza-cal em função do período de cura, respectivamente.

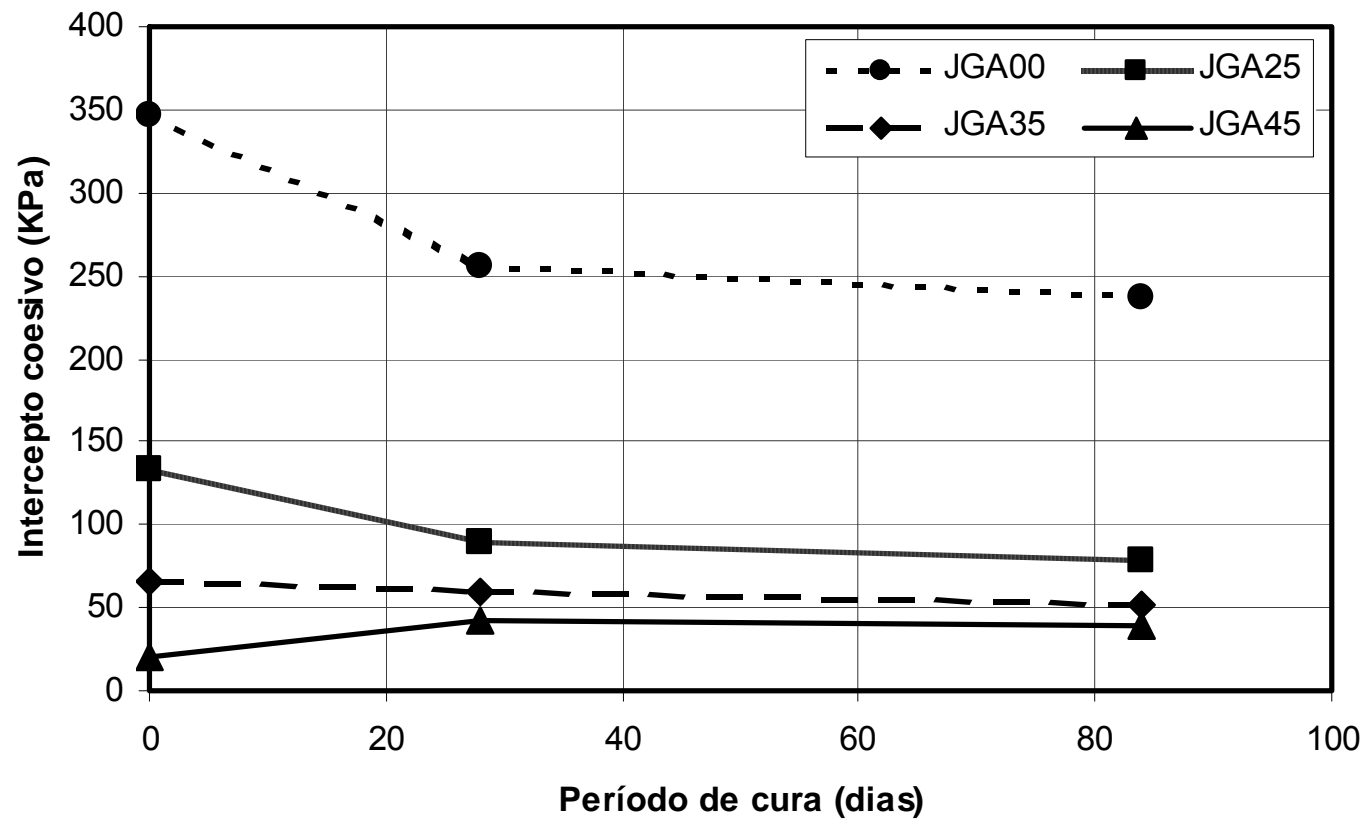

FIGURA 4.31 - Intercepto coesivo das misturas do solo JG com cinza pesada em função do período de cura.

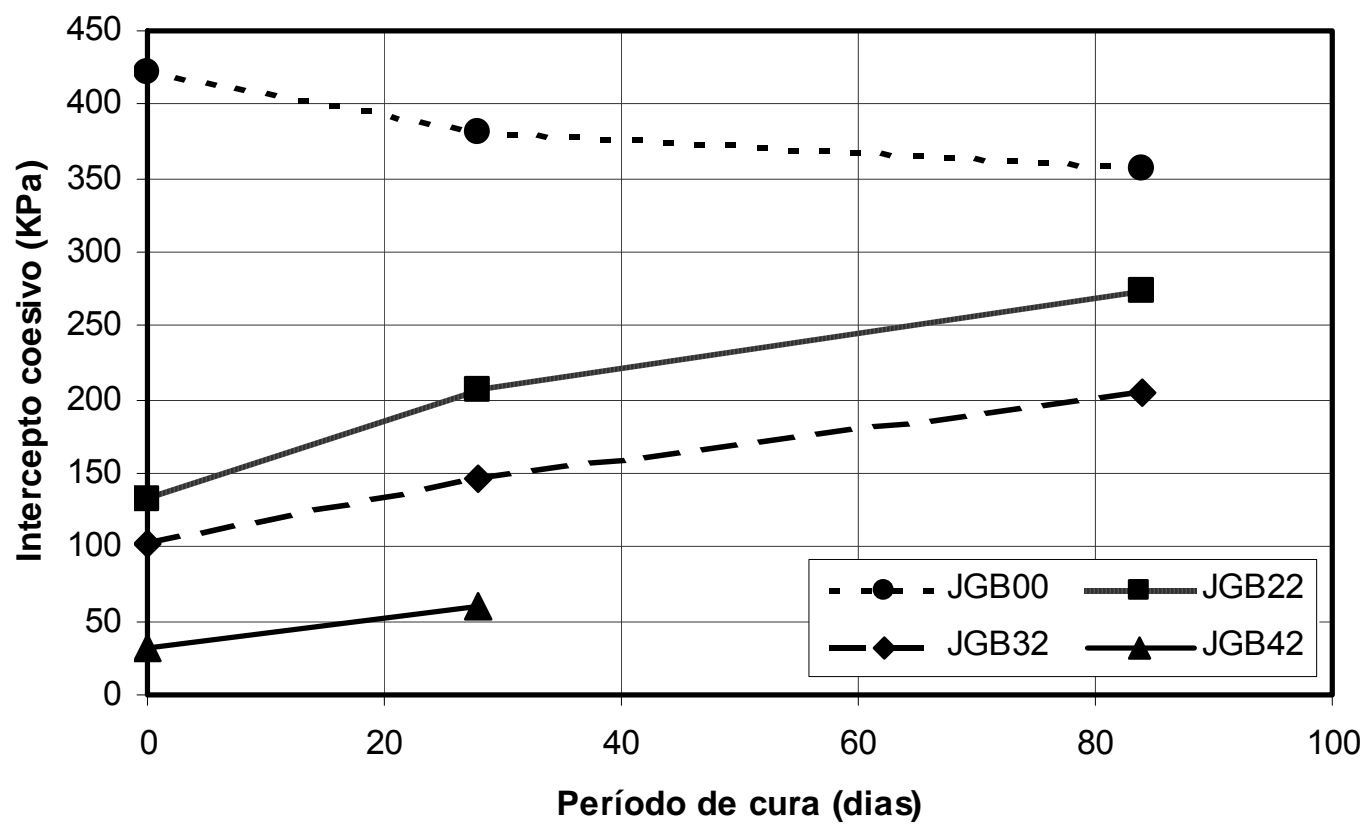

FIGURA 4.32 - Intercepto coesivo das misturas do solo JG com cinza pesada e cal em função do período de cura.

Observando-se as figuras 4.31 e 4.32 constata-se que não houve reações pozolânicas entre a cinza pesada e os solos que conduzissem a 
aumentos significativos dos interceptos coesivos ao longo do tempo de cura. Todavia, após a adição de $3 \%$ de cal os valores de intercepto coesivo apresentaram aumentos ao longo do tempo, caracterizando a ocorrência de reações pozolânicas nas misturas de solo-cinza-cal. Mesmo após 28 dias as misturas solo-cinza-cal continuaram apresentando aumentos extremamente importantes do intercepto coesivo diferentemente do que ocorreu para os solos puros. Desse modo, pode-se concluir que os ganhos de intercepto coesivo obtidos ao longo do tempo devem-se, principalmente, às reações entre a cinza pesada e a cal.

A tabela 4.6 mostra os valores de ângulo de atrito ( $\varnothing)$ obtidos graficamente a partir dos círculos de Mohr Coulomb, dos solos e das misturas de solo-cal, solo-cinza e solo-cinza-cal, para todos os períodos de cura.

TABELA 4.6 - Ângulo de atrito dos solos e das misturas de solo-cal, solocinza e solo-cinza-cal para todos os períodos de cura.

\begin{tabular}{|c|c|c|c|c|c|c|c|}
\hline \multirow{4}{*}{ Solo } & \multirow{4}{*}{$\begin{array}{c}\text { Teor de } \\
\text { Cinza } \\
(\%)\end{array}$} & \multicolumn{6}{|c|}{ Ângulo de Atrito (graus) } \\
\hline & & \multicolumn{6}{|c|}{ Período de Cura (dias) } \\
\hline & & \multicolumn{2}{|c|}{0} & \multicolumn{2}{|c|}{28} & \multicolumn{2}{|c|}{84} \\
\hline & & Sem Cal & Com Cal & Sem Cal & Com Cal & Sem Cal & Com Cal \\
\hline \multirow{4}{*}{ TM } & 0 & 37 & 41 & 51 & 45 & 55 & 52 \\
\hline & 25 & 58 & 54 & 61 & 55 & 61 & 55 \\
\hline & 35 & 54 & 52 & 60 & 58 & 54 & 61 \\
\hline & 45 & 54 & 56 & 57 & 63 & 60 & 62 \\
\hline \multirow{4}{*}{ JG } & 0 & 50 & 25 & 46 & 51 & 59 & 59 \\
\hline & 25 & 36 & 41 & 56 & 54 & 62 & 56 \\
\hline & 35 & 51 & 55 & 63 & 54 & 65 & 54 \\
\hline & 45 & 54 & 59 & 50 & 65 & 44 & - \\
\hline \multirow{4}{*}{ SG } & 0 & 52 & 44 & 53 & 50 & 59 & 54 \\
\hline & 25 & 58 & 53 & 43 & 57 & 36 & 57 \\
\hline & 35 & 57 & 60 & 48 & 58 & 41 & 56 \\
\hline & 45 & 60 & 67 & 63 & 58 & 63 & 59 \\
\hline
\end{tabular}

* Para as misturas com cal o teor de cinza é reduzido em $3 \%$.

Da análise da tabela 4.6, observa-se que geralmente teores crescentes de cinza pesada conduziram a valores crescentes de ângulo de atrito tanto das misturas solo-cinza quanto das misturas solo-cinza-cal. Esse fato se deve, provavelmente, ao caráter granular da cinza pesada. A figura 4.33 ilustra a variação do ângulo de atrito em função do teor de cinza pesada para todas as misturas solo-cinza. 


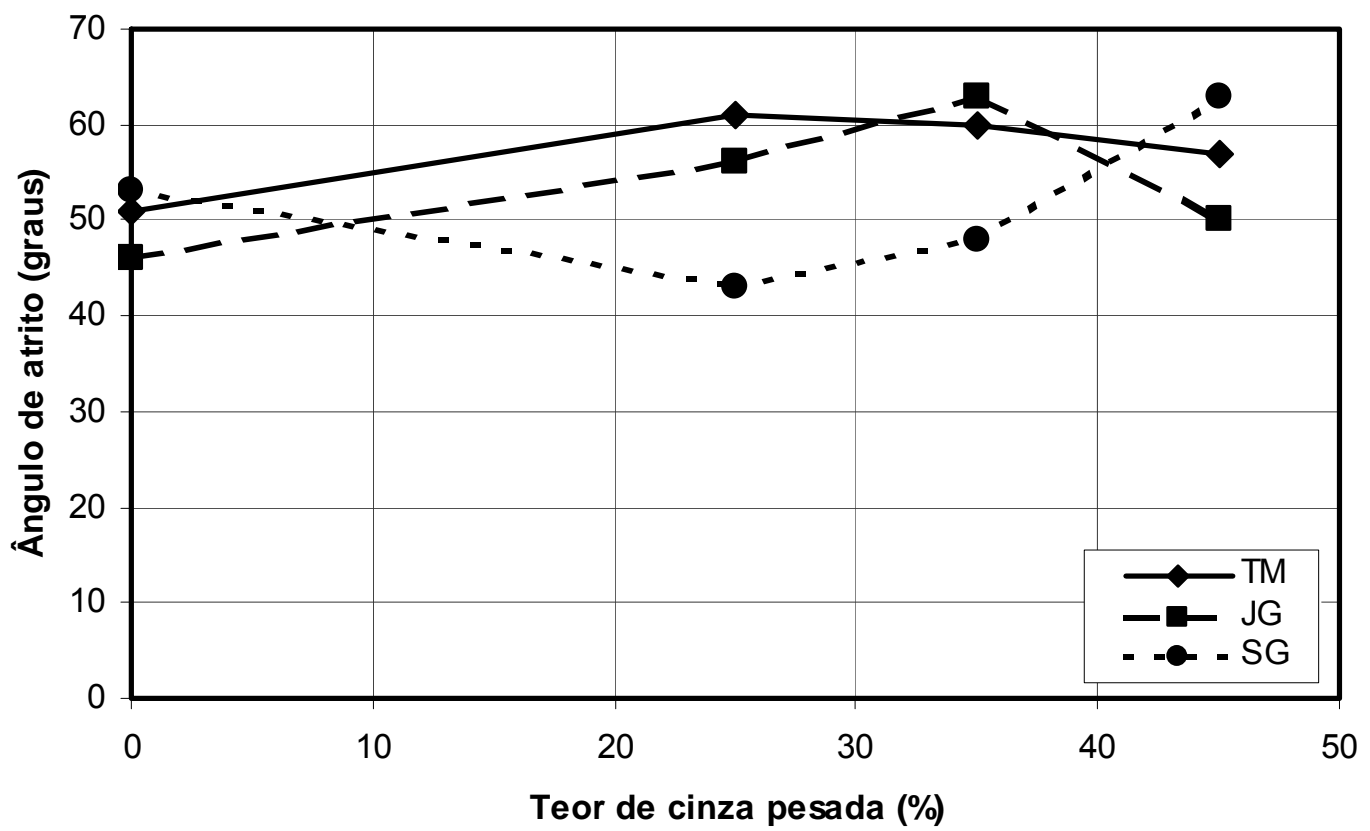

FIGURA 4.33 - Variação do ângulo de atrito das misturas solo-cinza aos 28 dias de cura em função do teor de cinza pesada.

Através da figura 4.33 verifica-se que as misturas de solo-cinza apresentaram, quase sempre, valores de ângulo de atrito maiores do que os solos puros. Na maioria das vezes, as misturas do solo SG com cinza pesada apresentaram valores de ângulo de atrito menores do que as outras misturas para a adição de até $35 \%$ de cinza. Acima desse teor os valores de ângulo de atrito para este solo foram os maiores para os três períodos de cura (tabela 4.6). Esse aumento nos valores de ângulo de atrito após a adição dos teores de cinza pesada é função do seu aspecto granular.

Como pode-se observar na tabela 4.6, os comportamentos das misturas solo-cinza-cal em função do teor de cinza pesada foram relativamente parecidos. A figura 4.34 mostra a variação do ângulo de atrito das misturas solo-cinza-cal aos 28 dias de cura, em função do teor de cinza pesada, para os três solos estudados. 


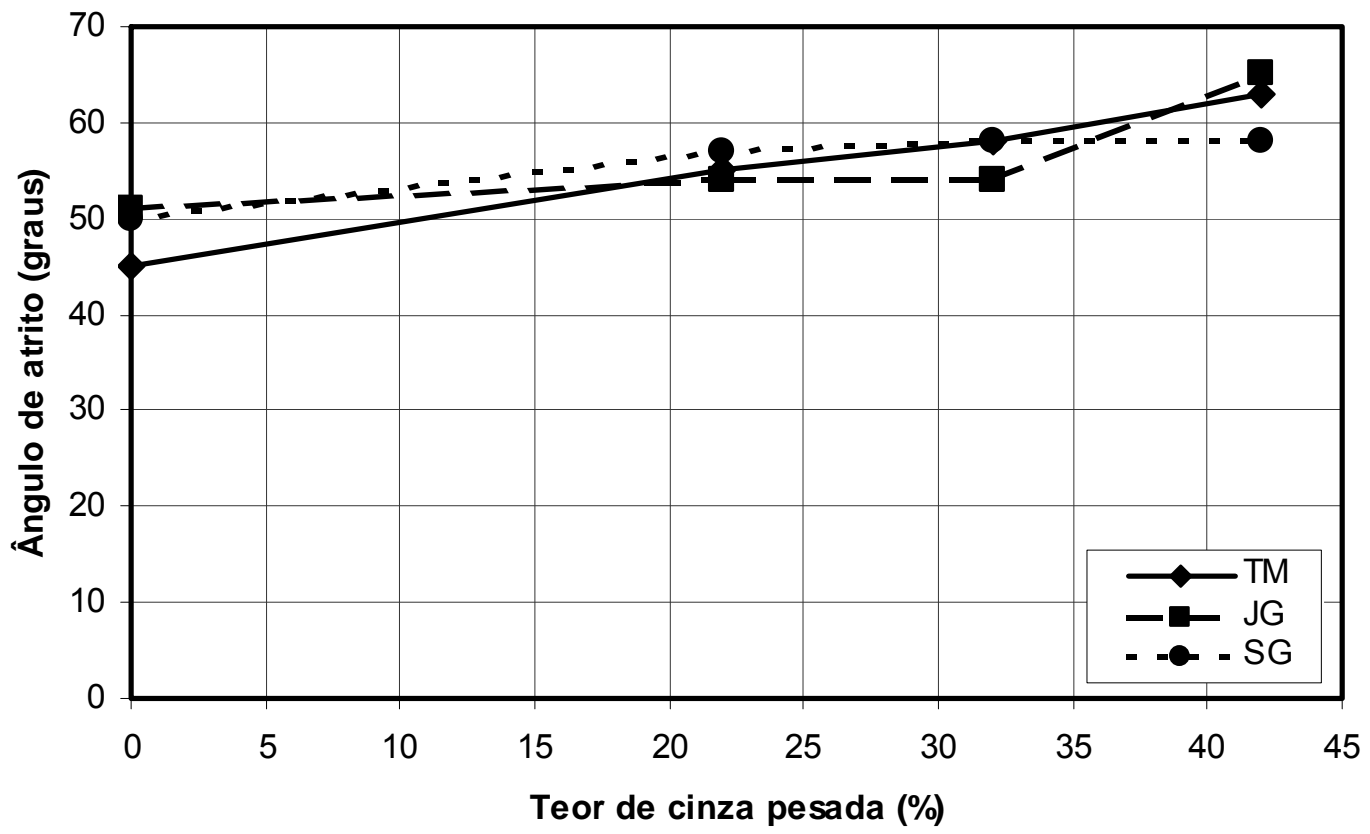

FIGURA 4.34 - Variação do ângulo de atrito das misturas solo-cinza-cal aos 28 dias de cura em função do teor de cinza pesada.

Os valores de ângulo de atrito das misturas solo-cinza-cal foram relativamente semelhantes para um mesmo teor de cinza, sendo que o aumento do seu teor conduziu à elevação do ângulo de atrito, ou seja, constata-se a influência da granulometria da cinza nas misturas com cal.

Contudo, ao comparar os valores de ângulo de atrito de uma mistura solo-cinza com os de uma mistura solo-cinza-cal nota-se que a adição de cal exerceu pouca ou quase nenhuma influência. A figura 4.35 mostra a influência da adição de cal nos valores de ângulo de atrito. 


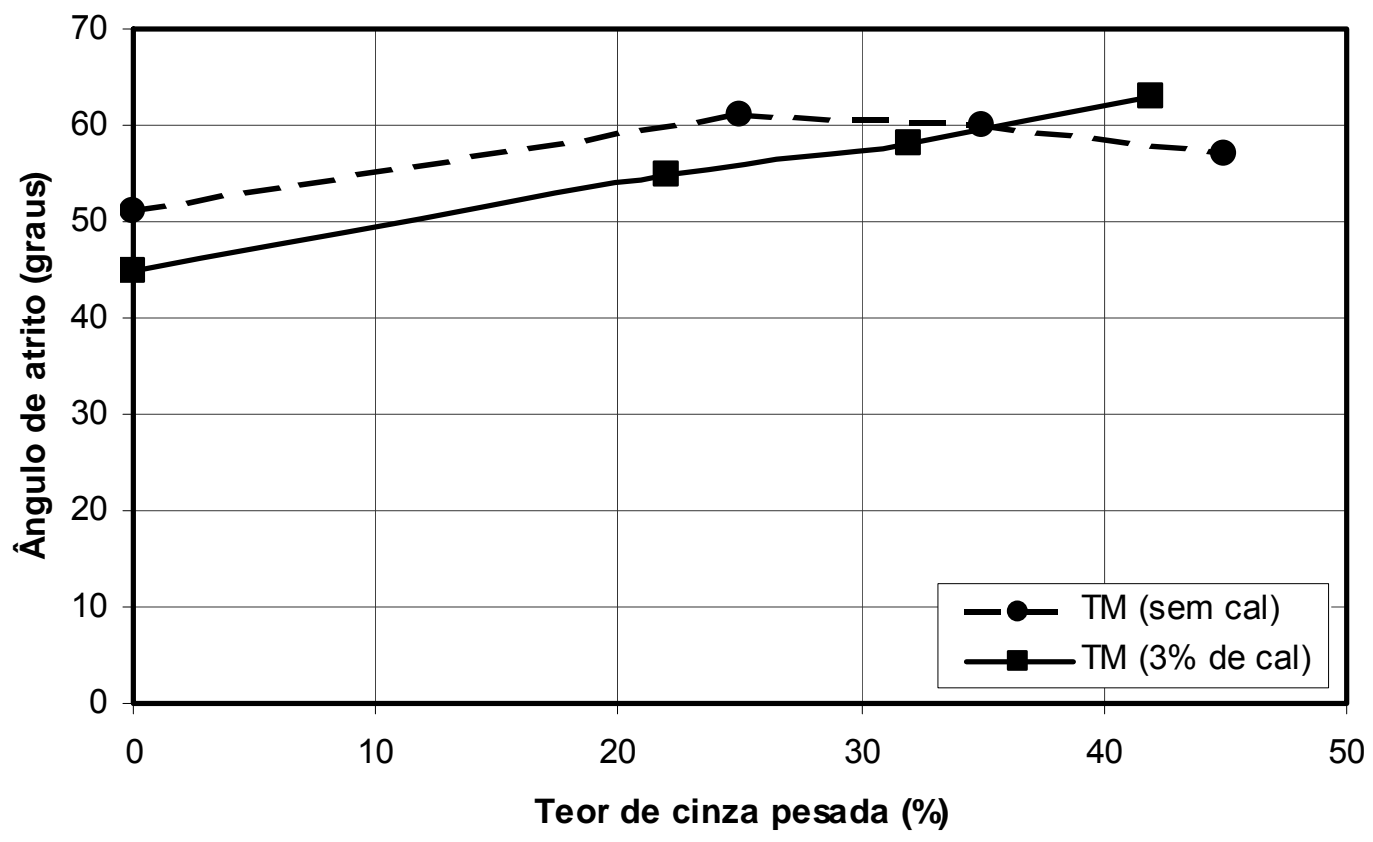

FIGURA 4.35 - Influência da adição de 3\% de cal às misturas do solo TM com cinza pesada aos 28 dias de cura.

Constata-se através da análise figura 4.35 que a adição de $3 \%$ de cal não exerceu nenhuma influência significativa sobre os valores de ângulo de atrito das misturas solo-cinza, uma vez que, para um mesmo teor de cinza pesada, os valores foram relativamente semelhantes.

Normalmente, para as misturas do solo laterítico JG com cinza pesada, os valores de ângulo de atrito foram maiores do que os apresentados por essas misturas após a adição de cal. Em contrapartida, para as misturas dos solos não lateríticos com cinza e cal, os valores de ângulo de atrito foram, na maioria das vezes, no mínimo, iguais aos das misturas desse tipo de solo com cinza pesada.

O tempo de cura aos quais as misturas de solo-cinza e solo-cinza-cal foram submetidas também não exerceu efeito significativo nos valores de ângulo de atrito. Esse fato pode ser comprovado através das figuras $4.36 \mathrm{e}$ 4.37, que apresentam as variações dos ângulos de atrito das misturas solocinza e, em seguida, das misturas solo-cinza-cal, em função do tempo de cura. 


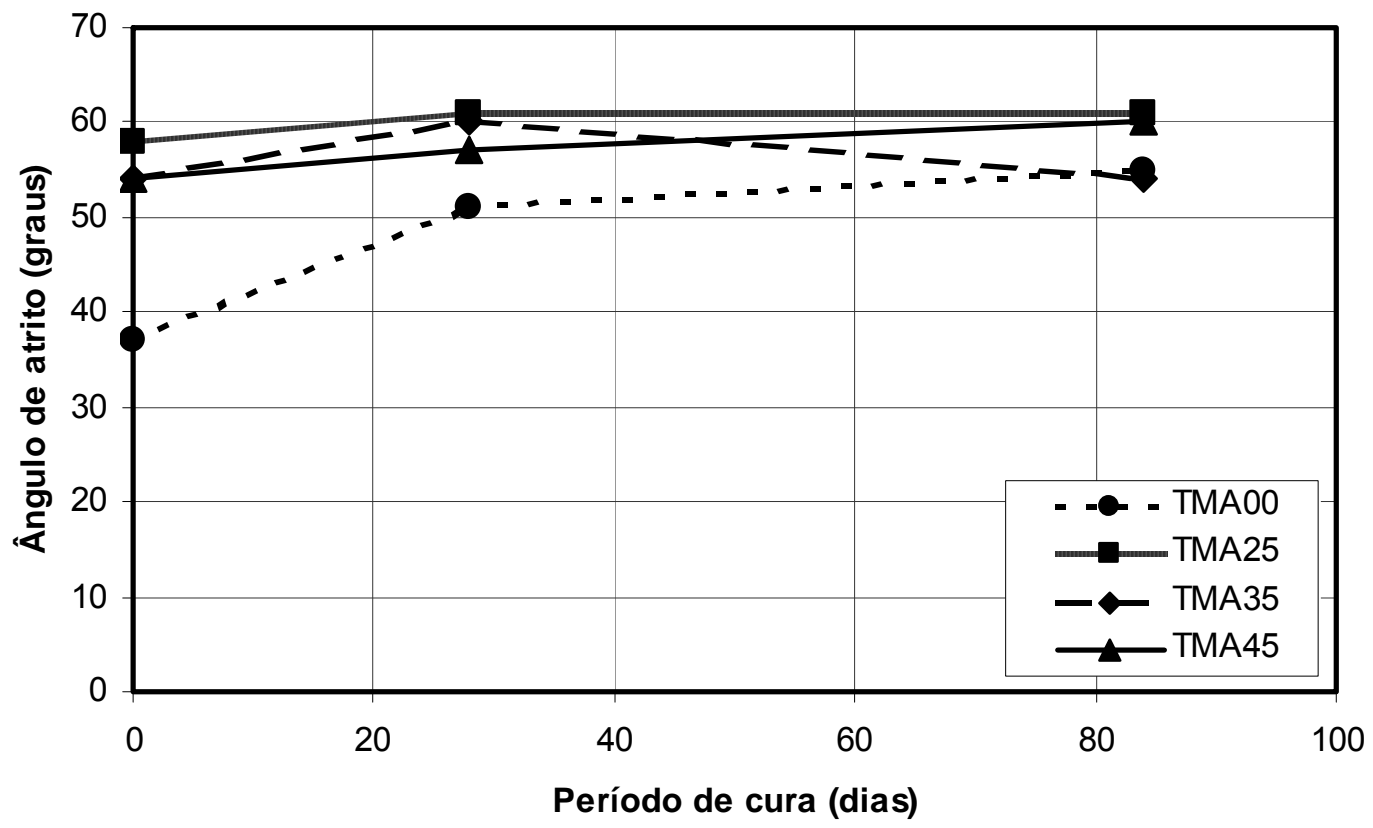

FIGURA 4.36 - Variação do ângulo de atrito das misturas do solo TM com cinza pesada em função do período de cura.

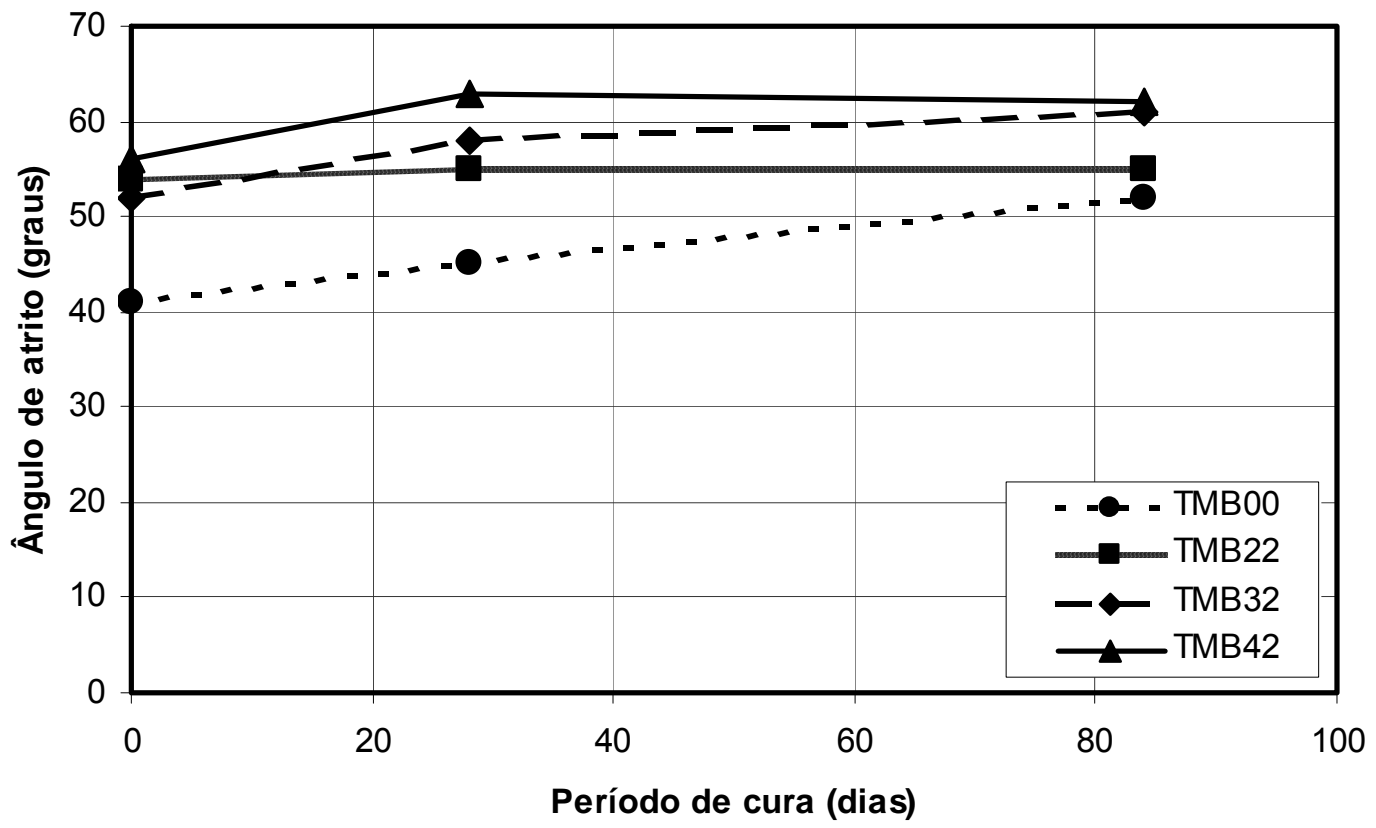

FIGURA 4.37 - Variação do ângulo de atrito das misturas do solo TM com cinza pesada e cal em função do período de cura.

Analisando-se a figura 4.36, verifica-se que os valores de ângulo de atrito das misturas solo-cinza foram pouco influenciados pelo tempo de cura, uma vez que os aumentos obtidos ao longo do tempo foram pouco significativos. 
Após a adição do teor de $3 \%$ de cal nota-se que ocorreu um aumento mais importante nos valores de ângulo de atrito ao longo do tempo de cura (figura 4.37). Contudo, esse aumento é observado apenas de zero para 28 dias de cura. Após esse período não ocorreram mais aumentos notáveis de ângulo de atrito para as misturas solo-cinza-cal.

\subsection{5 - Resultados dos Ensaios de CBR}

Os ensaios de CBR, realizados nesta pesquisa com intuito especulativo, são comumente utilizados no dimensionamento de pavimentos. O ensaio de CBR foi executado para as misturas do solo laterítico (JG) e do não laterítico (SG) com cinza e, também, com cinza e cal.

\subsubsection{1 - Influência das adições de cinza pesada e da cal sobre o CBR das misturas de solo-cinza e solo-cinza-cal}

A tabela 4.7 apresenta os valores de CBR obtidos para as misturas dos solos JG e SG com cinza pesada e com cinza pesada e cal.

TABELA 4.7 - CBR das misturas de solo-cinza e solo-cinza-cal.

\begin{tabular}{|c|c|c|c|c|}
\hline \multirow{2}{*}{ Solo } & \multicolumn{2}{|c|}{ Misturas sem Cal } & \multicolumn{2}{c|}{ Misturas com Cal } \\
\cline { 2 - 5 } & Mistura & CBR (\%) & Mistura & CBR (\%) \\
\hline \multirow{3}{*}{$J G(L G ')$} & $\mathrm{JGA}_{00}$ & 43 & $\mathrm{JGB}_{00}$ & 76 \\
\cline { 2 - 5 } & $\mathrm{JGA}_{25}$ & 50 & $\mathrm{JGB}_{22}$ & 67 \\
\cline { 2 - 5 } & $\mathrm{JGA}_{35}$ & 39 & $\mathrm{JGB}_{32}$ & 107 \\
\cline { 2 - 5 } & $\mathrm{JGA}_{45}$ & 24 & $\mathrm{JGB}_{42}$ & 32 \\
\hline \multirow{3}{*}{$\mathrm{SG}(\mathrm{NG})$} & $\mathrm{SGA}_{00}$ & 7 & $\mathrm{SGB}_{00}$ & 37 \\
\cline { 2 - 5 } & $\mathrm{SGA}_{25}$ & 4 & $\mathrm{SGB}_{22}$ & 55 \\
\cline { 2 - 5 } & $\mathrm{SGA}_{35}$ & 13 & $\mathrm{SGB}_{32}$ & 43 \\
\cline { 2 - 5 } & $\mathrm{SGA}_{45}$ & 32 & $\mathrm{SGB}_{42}$ & 56 \\
\hline
\end{tabular}

Analisando-se a tabela 4.7 verifica-se que o solo laterítico apresentou CBR muito maior do que o solo não laterítico. Entretanto, com as adições crescentes de cinza pesada, o CBR das misturas do solo laterítico JG diminuíram gradativamente. Apenas a mistura $\mathrm{JGA}_{25}$ apresentou um pequeno aumento no valor de CBR em relação ao solo JG puro. Já as misturas do solo 
não laterítico SG com cinza pesada apresentaram ganhos significativos no valor de CBR com o aumento do teor de cinza chegando a, aproximadamente, $360 \%$ de aumento.

Ainda pela análise da tabela 4.7 observa-se que após a adição de $3 \%$ de cal às misturas solo-cinza ocorreram ganhos expressivos de CBR para as misturas tanto do solo laterítico quanto para o solo não laterítico. Entretanto, as misturas do solo não laterítico com cinza pesada apresentaram ganhos maiores após a adição de $3 \%$ de cal do que as misturas do solo laterítico JG. Isto é, as misturas solo-cinza do solo SG mostraram-se mais reativas à adição da cal.

Outro aspecto importante a ser observado é que os maiores ganhos de CBR, após a adição de cal, ocorreram para as misturas solo-cinza do que para os solos puros, ou seja, as misturas solo-cinza são mais sensíveis à ação da cal.

A figura 4.38 ilustra a variação dos valores de CBR das misturas solocinza e solo-cinza-cal em função do teor de cinza pesada.

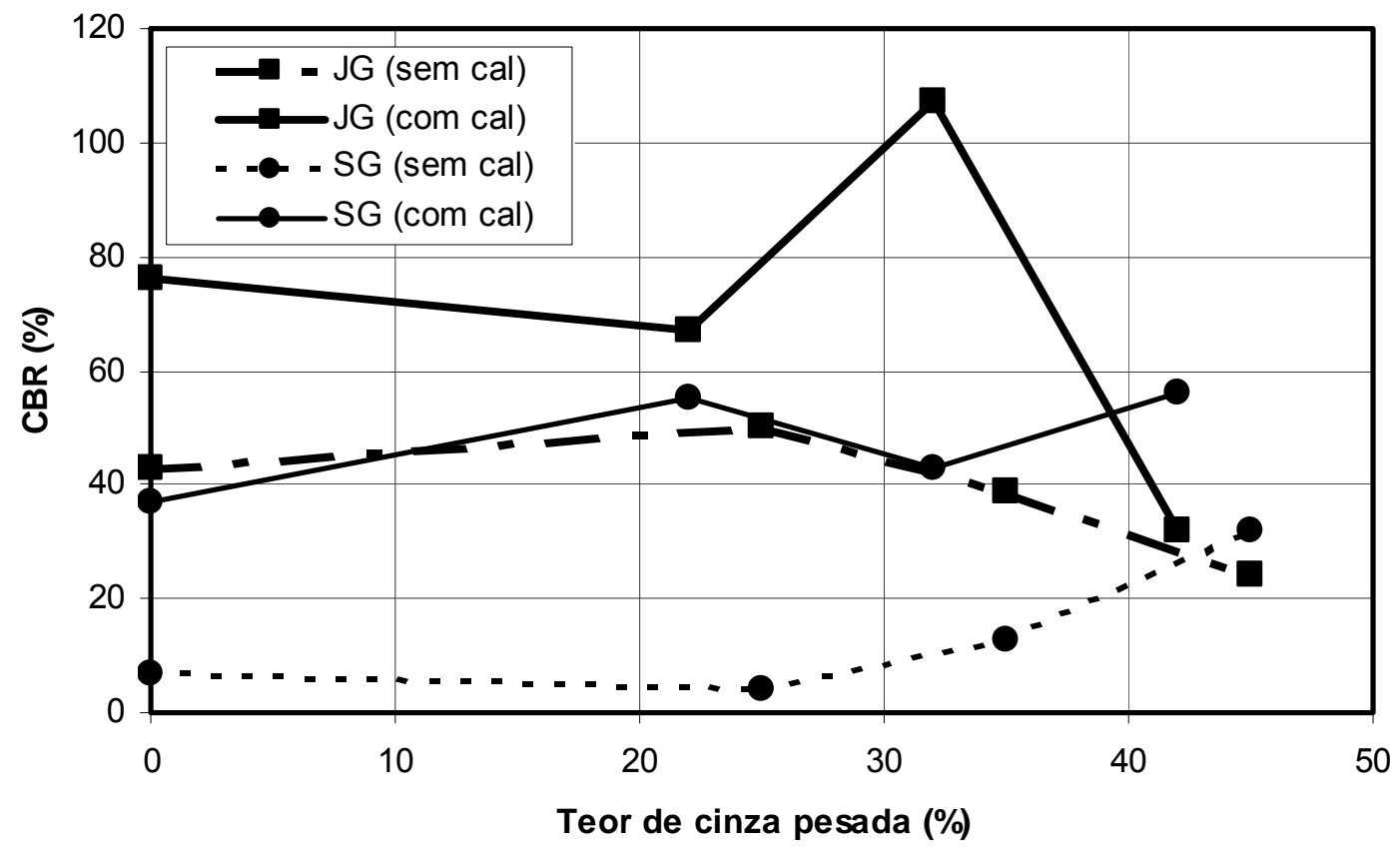

FIGURA 4.38 - Variação do CBR em função do teor de cinza pesada para as misturas de solo-cinza e solo-cinza-cal. 
Através da comparação das curvas de CBR em função do teor de cinza pesada das misturas com cal (linhas cheias) com as sem cal (linhas tracejadas) da figura 4.38, observa-se o efeito positivo da adição do teor de $3 \%$ de cal. Todas as misturas de solo-cinza-cal apresentaram valores de CBR significativamente maiores em relação às misturas de solo-cinza.

A curva de CBR versus teor de cinza pesada para as misturas do solo JG com cinza e cal apresentou um valor máximo de CBR como ocorrido para a curva das misturas apenas de solo-cinza. Contudo, para as misturas desse solo com cinza e cal o pico foi mais bem definido e o teor de cinza para o qual se obteve o maior valor de CBR foi de $32 \%$.

As misturas do solo SG com cinza pesada e cal apresentaram curva de CBR em função do teor de cinza que tende, aparentemente, a valores de CBR maiores com o aumento do teor de cinza pesada. Porém, para o teor de $32 \%$ de cinza ocorreu um decréscimo no valor de CBR em relação ao teor de $22 \%$.

Nota-se ainda pela tabela 4.7 e pela figura 4.38 que as misturas solocinza do solo não laterítico SG após a adição de cal apresentaram ganhos maiores nos valores de CBR do que as misturas do solo laterítico JG evidenciando, mais uma vez, que as misturas do solo SG com cinza são mais sensíveis às adições de cal.

O melhor comportamento das misturas solo-cinza-cal em relação ás misturas de solo-cinza, solo-cal e solo puro, se deve às reações ocorridas entre a cinza e a cal que, através da formação de novos compostos cimentantes, contribuíram para a elevação dos valores de CBR, principalmente, para os teores entre 22 e $32 \%$ de cinza pesada.

\subsubsection{2 - Influência das adições de cinza pesada e da cal sobre a expansão das misturas de solo-cinza e solo-cinza-cal}

A tabela 4.8 apresenta os valores de expansão obtidos para as misturas de solo-cinza e solo-cinza-cal dos solos JG e SG. 
TABELA 4.8 - Expansão das misturas de solo-cinza e solo-cinza-cal.

\begin{tabular}{|c|c|c|c|c|}
\hline \multirow{2}{*}{ Solo } & \multicolumn{2}{|c|}{ Misturas sem Cal } & \multicolumn{2}{c|}{ Misturas com Cal } \\
\cline { 2 - 5 } & Mistura & Expansão (\%) & Mistura & Expansão (\%) \\
\hline \multirow{3}{*}{$J G(L G ')$} & $\mathrm{JGA}_{00}$ & 0,35 & $\mathrm{JGB}_{00}$ & 0,02 \\
\cline { 2 - 5 } & $\mathrm{JGA}_{25}$ & 0,04 & $\mathrm{JGB}_{22}$ & 0,01 \\
\cline { 2 - 5 } & $\mathrm{JGA}_{35}$ & 0,03 & $\mathrm{JGB}_{32}$ & 0,00 \\
\cline { 2 - 5 } & $\mathrm{JGA}_{45}$ & 0,03 & $\mathrm{JGB}_{42}$ & 0,00 \\
\hline \multirow{3}{*}{ SG (NG') } & $\mathrm{SGA}_{00}$ & 0,19 & $\mathrm{SGB}_{00}$ & 0,02 \\
\cline { 2 - 5 } & $\mathrm{SGA}_{25}$ & 0,11 & $\mathrm{SGB}_{22}$ & 0,01 \\
\cline { 2 - 5 } & $\mathrm{SGA}_{35}$ & 0,03 & $\mathrm{SGB}_{32}$ & 0,00 \\
\cline { 2 - 5 } & $\mathrm{SGA}_{45}$ & 0,02 & $\mathrm{SGB}_{42}$ & 0,00 \\
\hline
\end{tabular}

As expansões, tanto para o solo puro JG, quanto para o SG, foram menores do que 0,35\% como pode ser observado na tabela 4.8. Mesmo assim, as adições de cinza pesada proporcionaram a diminuição da expansão das misturas de solo-cinza. Esse fato mostra que a cinza atuou de maneira positiva na redução das expansões das misturas. Com a adição de $3 \%$ de cal as expansões de todas as misturas de solo-cinza-cal foram praticamente nulas.

\subsection{6 - Resistência à Compressão Simples na Condição Imersa das Misturas de Solo-Cinza e Solo-Cinza-Cal aos 7 Dias de Cura}

Para avaliar a influência da ação da água no comportamento mecânico das misturas de solo-cinza e solo-cinza-cal moldou-se, apenas para o solo laterítico JG, um corpo-de-prova para cada uma das misturas, sem réplica, devido à falta de material. Optou-se nesse momento, com base nos ensaios anteriores de resistência à compressão simples, em substituir em $5 \%$ as adições iniciais de cinza pesada por cal, ou seja, as misturas de solo-cinza-cal foram elaboradas nas seguintes proporções:

JGB 00 - Solo-cal: $95 \%+5 \%$

JGB $_{20}$ - Solo-cinza-cal: $75 \%+20 \%+5 \%$

JGB $_{30}$ - Solo-cinza-cal: $65 \%+30 \%+5 \%$

JGB $_{40}$ - Solo-cinza-cal: $55 \%+40 \%+5 \%$

Após a moldagem, os corpos-de-prova foram embalados e levados à câmara úmida onde ficaram por 7 dias. Decorrido esse período os corpos-de- 
prova foram colocados dentro de um recipiente com água ficando totalmente submersos por 4 horas e depois disso foram realizados os ensaios de resistência à compressão simples.

A influência das adições de cinza pesada e de $5 \%$ de cal, na resistência à compressão simples na condição imersa, é ilustrada na figura 4.39. Nessa figura também são apresentadas as curvas de resistência à compressão simples em função do teor de cinza pesada para as misturas de solo-cinza e solo-cinza-cal aos 28 dias de cura na condição não imersa para efeito de comparação.

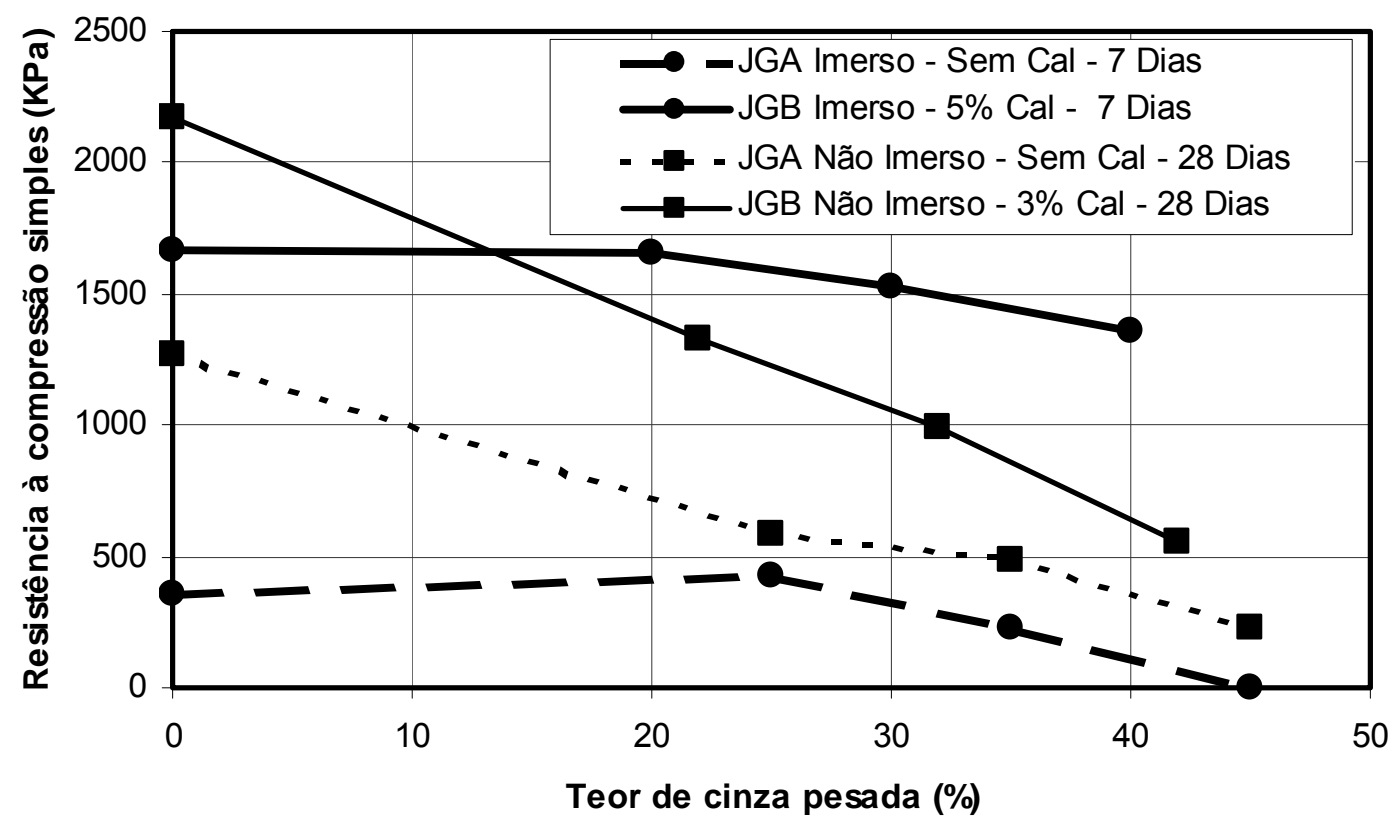

FIGURA 4.39 - Resistência à compressão simples versus teor de cinza pesada nas condições imersa e não imersa das misturas de solo-cinza e solo-cinza-cal.

Devido à imersão em água as misturas solo-cinza apresentaram um ligeiro decréscimo na resistência à compressão simples (figura 4.39). O solo puro foi o que apresentou maior queda de resistência à compressão simples quando comparado com a condição não imersa.

A imersão do corpo-de-prova da mistura com $25 \%$ de cinza pesada apresentou resistência à compressão simples pouco inferior à resistência dessa mesma mistura na condição não imersa e com 28 dias de cura. A resistência à compressão simples imersa permaneceu praticamente constante 
até a adição de $25 \%$ de cinza pesada ao solo. Para teores maiores de cinza ocorreram diminuições significativas, sendo que, para a mistura com 45\% de cinza o corpo-de-prova se desmanchou não apresentando estabilidade frente à ação da água.

Com adição de $5 \%$ cal, observa-se, através da figura 4.39 que houve um aumento da resistência à compressão simples na condição imersa em relação as misturas apenas de solo-cinza, ou seja, a cal atuou de maneira importante na melhora da estabilidade das misturas de solo-cinza em relação a ação da água.

A resistência à compressão simples imersa da mistura solo-cinza-cal com $20 \%$ de cinza foi praticamente a mesma obtida para a mistura solo-cal e, em seguida, ocorreram diminuições de resistência para teores maiores de cinza pesada. Entretanto, as resistências obtidas na condição imersa para todas as misturas solo-cinza-cal foram muito significativas.

Nota-se pela figura 4.39, que as resistências obtidas para as misturas de solo-cinza-cal com $5 \%$ de cal na condição imersa foram consideravelmente maiores do que as resistências à compressão simples das misturas de solocinza-cal na condição não imersa com 28 dias de cura e 3\% de cal, enquanto que o solo-cal após a imersão em água apresentou uma redução significativa de resistência. Pode-se dizer então, que a imersão e a maior quantidade de cal atuaram de maneira positiva nas misturas de solo-cinza. 


\section{CAPÍTULO 5} CONCLUSÕES

O objetivo principal desta dissertação foi investigar, através de ensaios laboratoriais, os efeitos da cinza pesada quando incorporada a solos, visando o aproveitamento deste resíduo na construção rodoviária. O comportamento mecânico foi estudado com base na determinação da resistência à compressão simples, resistência à tração por compressão diametral e, a título especulativo, através de ensaios de CBR. As principais conclusões obtidas foram:

- Quanto às adições de cinza pesada

Verificou-se que o aumento da quantidade de cinza adicionada aos solos resultou na diminuição das massas específicas secas máximas e no aumento dos teores de umidade ótimos. Todavia, o aumento do teor de umidade até $35 \%$ de cinza pesada é pouco significativo.

As adições dos teores crescentes de cinza pesada aos solos atuaram de maneira negativa em relação aos valores de mini-CBR imediato, ou seja, na maior parte das vezes quanto maior o teor de cinza, menor o valor de miniCBR. Entretanto, após 24 horas de imersão em água, verificou-se o efeito benéfico da cinza, uma vez que ocorreram aumentos significativos nos valores para teores de até $35 \%$, provavelmente devido ao caráter granular da cinza pesada.

A maior estabilidade quanto à imersão em água das misturas de solocinza, com relação aos valores de mini-CBR, em comparação com os solos puros também ficou clara ao se analisar os resultados de RIS. Constatou-se 
que a relação entre mini-CBR após 24 horas de imersão e mini-CBR imediato foi maior para as misturas solo-cinza do que para os solos. Em alguns casos, as misturas solo-cinza apresentaram RIS maiores que $100 \%$, ou seja, não houve perda de capacidade de suporte após a imersão em água.

As adições de cinza pesada também atuaram de maneira positiva em se tratando de expansão e contração obtidas através dos ensaios de mini-CBR. Observou-se que adições crescentes de cinza pesada conduziram a expansões praticamente nulas das misturas solo-cinza e que as contrações reduziram de maneira significativa.

Com relação à resistência à compressão simples, resistência à compressão diametral e módulo tangente inicial foi constatado que os teores de cinza atuam de maneira negativa, provocando a diminuição acentuada de seus valores.

O aumento do teor de cinza nas misturas com os solos resultou também na diminuição dos interceptos coesivos e no aumento dos ângulos de atrito, provavelmente devido à distribuição granulométrica da cinza, tipicamente de areia fina.

Outro aspecto importante quanto ao teor de cinza presente nas misturas com os solos é com relação aos valores de CBR. Constatou-se que as adições de cinza pesada exercem influência mais positiva nos valores de CBR do solo não laterítico do que nos do laterítico. Enquanto que para as misturas do solo laterítico ocorreram reduções gradativas de CBR, para as misturas do solo não laterítico-cinza ocorreram aumentos consideráveis.

- Quanto à adição de 3\% de cal

Observou-se que também ocorrem diminuições importantes de resistência à compressão simples devido aos teores crescentes de cinza pesada. No entanto, para um teor semelhante de cinza ficou evidente o 
aspecto extremamente positivo da adição da cal, alcançando-se ganhos percentuais de até $200 \%$ de resistência à compressão simples.

Constatou-se também que os ganhos de resistência à compressão simples obtidos pelas misturas solo-cinza foram, geralmente, maiores que os ganhos apresentados pelos solos após a adição da cal. Desse modo, pode-se admitir que esses maiores ganhos se devem, principalmente, às reações ocorridas entre os compostos de cinza pesada e cal. Comportamento semelhante ocorreu para a resistência à tração por compressão diametral e também para o módulo tangente inicial e intercepto coesivo.

A adição de cal exerceu pouca influência sobre os valores de ângulo de atrito das misturas de solo-cinza, uma vez que, para um teor semelhante de cinza pesada, os valores de ângulo de atrito foram relativamente parecidos.

Todas as misturas de solo-cinza apresentaram ganhos consideráveis de CBR após a adição de cal. As misturas do solo laterítico com cinza apresentaram ganhos absolutos maiores do que as misturas do solo não laterítico com cinza pesada após a adição de cal. Contudo, as misturas do solo não laterítico apresentaram ganhos relativos maiores. Verificou-se também, através dos ensaios de CBR, que as adições de cinza pesada proporcionaram a diminuição das expansões e que, com a adição de cal, as expansões de todas as misturas de solo-cinza-cal foram praticamente nulas.

- Quanto a influência do período de cura

Verificou-se que os aumentos ocorridos de resistência à compressão simples ao longo do tempo não foram significativos na maior parte das vezes, ou seja, não foram observadas reações pozolânicas importantes entre os solos e os teores de cinza pesada.

Observou-se também que a taxa de aumento de resistência após 28 dias de cura é maior para os solos-cinza-cal do que para os solos-cal. Esse 
fato indica que a cal atuou de maneira mais eficiente na presença da cinza pesada ao longo do tempo.

O período de cura também exerceu maior influência no módulo tangente inicial nas misturas que continham cal, ou seja, as reações pozolânicas que proporcionaram a cimentação das partículas e, conseqüentemente, elevaram os valores de resistência à compressão simples e módulo tangente inicial se deram após as adições de cal. Essas reações também foram mais eficientes quando se teve nas misturas a presença ao mesmo tempo da cinza e da cal.

Com relação à resistência à tração por compressão diametral, a ocorrência de reações pozolânicas ficou, como nos casos anteriores, mais clara após a adição de cal e os maiores ganhos se deram, geralmente, para teores maiores de cinza presentes nas misturas. Mais uma vez ficou evidente o desencadeamento de reações lentas ao longo do tempo entre a cinza pesada e a cal que atuaram na elevação das resistências.

Ao longo do período de cura, as misturas solo-cinza-cal apresentaram ganhos importantes de intercepto coesivo. Já para as misturas de solo-cinza não foram constatadas reações que contribuíssem de maneira significativa para a elevação do intercepto coesivo dessas misturas.

Também não foram observados ganhos significativos de ângulo de atrito ao longo do tempo de cura para as misturas solo-cinza e nem para as misturas solo-cinza-cal.

- Quanto à influência da imersão em água

À luz dos resultados de Mini-CBR após imersão em água, concluí-se que a cinza atua de maneira positiva quando incorporada aos solos, uma vez que, a perda de capacidade de suporte devido à imersão é menor para as misturas solo-cinza do que para os solos puros. Além disso, as misturas solo-cinza apresentaram valores de Mini-CBR sempre maiores do que os dos solos após a imersão em água. 
Com relação aos ensaios de resistência à compressão simples após imersão em água, concluiu-se que para as misturas de solo-cinza, na condição imersa, o teor de $25 \%$ de cinza pesada com o solo laterítico, apresenta boa estabilidade frente à ação da água, com resistência muito semelhante à obtida na condição não imersa. Entretanto, o solo laterítico puro e as misturas com maior quantidade de cinza são mais sensíveis à ação da água, não apresentando estabilidade para o teor de $45 \%$ de cinza.

Com adição de $5 \%$ de cal ocorreu aumento elevado da resistência à compressão simples na condição imersa em relação às misturas apenas de solo-cinza, ou seja, a cal atuou de maneira importante na melhora da estabilidade das misturas de solo-cinza em relação à ação da água.

Por fim, conclui-se que a adição de cinza pesada aos solos não melhora as propriedades mecânicas das misturas compactadas na condição de teor de umidade ótimo e massa específica seca máxima. Desse modo, necessita-se de um estabilizante, como a cal, para melhorar as características das misturas solo-cinza. Com adição da cal verificou-se a melhora significativa quanto ao comportamento mecânico das misturas, representando uma solução factível para a utilização da cinza pesada em misturas com solo e cal para construção de bases e sub-bases de pavimentos flexíveis. 


\section{RECOMENDAÇÕES PARA TRABALHOS FUTUROS}

Como sugestão e recomendações para trabalhos futuros têm-se a necessidade de um estudo mais amplo quanto a deformabilidade das misturas de solo-cinza e solo-cinza-cal através de ensaios triaxiais levando-se em consideração o tempo e as condições de cura das misturas. Outros aspectos interessantes e, também, importantes de serem estudados são:

- Ampliar o estudo para outros tipos de solos;

- A elaboração de um método de dosagem de cal ou a escolha de um teor ótimo de cal para as misturas com solo-cinza com base no comportamento mecânico, sobretudo na resistência à compressão simples;

- Analisar o comportamento das misturas de solo-cinza com a adição de teores diferentes de cal e de outros estabilizantes como o cimento por exemplo;

- Estudar o comportamento mecânico apenas da cinza pesada com adições de estabilizantes como a cal através de ensaios de resistência à compressão simples, resistência à tração por compressão diametral, triaxiais cíclicos e, também, por ensaios complementares como o ensaio de CBR.

- Avaliar o efeito da imersão em água das misturas de solo-cinza-cal de maneira mais ampla variando-se os teores de cal adicionados às misturas de solo-cinza; 
- Verificar a influência das adições de cinza pesada e cal aos solos nos valores de CBR ao longo do tempo de cura;

- Analisar a influência da energia de compactação no comportamento mecânico das misturas de solo-cinza e solo-cinza-cal;

- Realizar um estudo avaliando o potencial contaminante da cinza pesada através de ensaios de lixiviação e solubilização das misturas de solocinza e solo-cinza-cal;

- Avaliar o comportamento das misturas de solo, cinza e cal, em campo, através da construção de trechos experimentais e seu monitoramento ao longo do tempo que permita avaliar seu desempenho.

- Análise econômica e ambiental das vantagens e desvantagens da utilização da cinza pesada na construção rodoviária. 


\section{RECOMENDAÇÕES PARA TRABALHOS FUTUROS}

Como sugestão e recomendações para trabalhos futuros têm-se a necessidade de um estudo mais amplo quanto a deformabilidade das misturas de solo-cinza e solo-cinza-cal através de ensaios triaxiais levando-se em consideração o tempo e as condições de cura das misturas. Outros aspectos interessantes e, também, importantes de serem estudados são:

- Ampliar o estudo para outros tipos de solos;

- A elaboração de um método de dosagem de cal ou a escolha de um teor ótimo de cal para as misturas com solo-cinza com base no comportamento mecânico, sobretudo na resistência à compressão simples;

- Analisar o comportamento das misturas de solo-cinza com a adição de teores diferentes de cal e de outros estabilizantes como o cimento por exemplo;

- Estudar o comportamento mecânico apenas da cinza pesada com adições de estabilizantes como a cal através de ensaios de resistência à compressão simples, resistência à tração por compressão diametral, triaxiais cíclicos e, também, por ensaios complementares como o ensaio de CBR.

- Avaliar o efeito da imersão em água das misturas de solo-cinza-cal de maneira mais ampla variando-se os teores de cal adicionados às misturas de solo-cinza; 
- Verificar a influência das adições de cinza pesada e cal aos solos nos valores de CBR ao longo do tempo de cura;

- Analisar a influência da energia de compactação no comportamento mecânico das misturas de solo-cinza e solo-cinza-cal;

- Realizar um estudo avaliando o potencial contaminante da cinza pesada através de ensaios de lixiviação e solubilização das misturas de solocinza e solo-cinza-cal;

- Avaliar o comportamento das misturas de solo, cinza e cal, em campo, através da construção de trechos experimentais e seu monitoramento ao longo do tempo que permita avaliar seu desempenho.

- Análise econômica e ambiental das vantagens e desvantagens da utilização da cinza pesada na construção rodoviária. 


\section{REFERÊNCIAS BIBLIOGRÁFICAS}

AMERICAN ASSOCIATION OF HIGHWAY AND TRANSPORTATION OFFICIALS (1986). AASHTO Designation TP46-94. Standard method for determining the resilient modulus of soils and aggregate materials. Washington, DC.

ASSOCIAÇÃO BRASILEIRA DE NORMAS TÉCNICAS (1984). NBR 6459 Solos - Determinação do limite de liquidez. Rio de Janeiro.

ASSOCIAÇÃO BRASILEIRA DE NORMAS TÉCNICAS (1984). NBR 6508 Solos - Determinação da massa específica. Rio de Janeiro.

ASSOCIAÇÃO BRASILEIRA DE NORMAS TÉCNICAS (1984). NBR 7180 Solos - Determinação do limite de plasticidade. Rio de Janeiro.

ASSOCIAÇÃO BRASILEIRA DE NORMAS TÉCNICAS (1984). NBR 7181 Solos - Análise granulométrica. Rio de Janeiro.

ASSOCIAÇÃO BRASILEIRA DE NORMAS TÉCNICAS (1987). NBR 9895 Solos - Índice de Suporte Califórnia. Rio de Janeiro.

CARVALHO, J. B. Q.; CABRERA, J. G. (1979). Um método simples para avaliar a reatividade à cal dos solos vermelhos tropicais. Congresso Panamericano de Mecânica dos Solos e Engenharia de Fundações, Anais, Lima, p. 485 - 501. 
CHAUVEL, A. C.; NOBREGA, M. T. (1980). Comportamento dos solos argilosos desenvolvidos sobre basaltos do Brasil Meridional, após tratamento com cal. São Paulo, Associação Brasileira dos Produtores de Cal, IV Reunião Aberta da Industria de Cal, Boletim n. 12, p. 125 - 172.

CHIES, F.; ZWONOK, O.; SILVA, N. H. W. (1998). Desenvolvimento de tijolos maciços a partir de cinza pesada e cal hidratada. Simpósio internacional de qualidade ambiental. Porto Alegre. Artigos Técnicos, p. 122 a 126.

COLLINS, R. J. (1979). Composition and characteristics of municipal incinerator residues. Transport Research Record, n. 734, p. 46-53.

CORREA, F. C. (1989). Contribuição à estabilização do latossolo roxo. São Calos. 83p. Tese (Doutorado). Escola de Engenharia de São Carlos. Universidade de São Paulo.

CUNTO, F. J. C. (1997). Determinação do módulo de resiliência através de ensaios triaxiais dinâmicos e a sua estimativa a partir de ensaios de compressão simples: estudo de três solos do nordeste brasileiro. São Carlos. 154p. Dissertação (Mestrado). Escola de Engenharia de São Carlos. Universidade de São Paulo.

DESCHAMPS, R. J. (1997). Geotechnical and environmental characteristics of atmospheric fluidized bed combustion ash and stoker ash. Transport Research Record, n. 1577, p. 90-95.

DEPARTAMENTO NACIONAL DE ESTRADAS DE RODAGEM (1997). DNER ME 180/94 - Solos estabilizados com cinza volante e cal hidratada determinação da resistência à compressão simples. Rio de Janeiro.

DEPARTAMENTO NACIONAL DE ESTRADAS DE RODAGEM (1997). DNER ME 181/94 - Solos estabilizados com cinza volante e cal hidratada determinação da resistência à tração por compressão diametral. Rio de Janeiro. 
DEPARTAMENTO NACIONAL DE ESTRADAS DE RODAGEM (1997). DNER ME 254/97 - Solos compactados com equipamento miniatura - Mini-CBR e expansão. Rio de Janeiro.

DEPARTAMENTO NACIONAL DE ESTRADAS DE RODAGEM (1994). DNER ME 258/94 - Solos compactados com equipamento miniatura - Mini-MCV. Rio de Janeiro.

DUCAN, J. M.; CHANG, C-Y. (1970). Nonlinear analysis of stress and strain in soils. Journal of the Soil Mechanics and Foundations Division. Proceedings of the American Society of Civil Engineers, n. SM5, p. 1629 - 1653.

FABBRI, G. T. P. (1994). Caracterização da fração fina de solos tropicais através da adsorção de azul de metileno. Tese de Doutorado. Escola de Engenharia de São Carlos, USP. São Carlos, 101 p.

FEDERAL HIGHWAY ADMINISTRATION: TURNER FAIRBANK HIGHAWAY RESEARCH CENTER (1998). User guidelines for waste and by-product material in pavement construction. FHWA-RD-97-148. United States Department of Transport.

GOODMAN, R. E. (1989). Introduction to rock mechanics. 2en ed. New York, Wiley. 562p.

GRESS, D.; ZHANG, X.; TARR, S.; PAZIENZA, I.; EIGHMY, T. (1992). Physical and environmental properties of asphalt-amended bottom ash. Transport Research Record, n. 1345, p. 10-18.

HARTY, J. R. (1971). Factors influencing the lime reactivity of tropically and subtropically weathered soils. University of Illinois at Urbana-Champaign, PhD thesis, $182 \mathrm{p}$.

HUANG, W. H.; LOVELL, C. W. (1990). Bottom ash as embankment material. Geothecnics of Waste Fills - Theory and Practice. STP 1070, p. 71-85. 
INGLES, O. G.; METCALF, J. B. (1973). Soil stabilization - principles and practice, New York, J. Wiley e Sons. 374 p.

KE, T. C. (1990). Physical durability and electrical resistivity of Indiana bottom ash. Indiana. 335p. Purdue University West Lafayette.

KE, T. C.; LOVELL, C. W. (1992). Corrosivity of Indiana Bottom Ash. Transportation Research Record, n. 1345, p.113-117.

KSAIBATI, K.; BOWEN, M. M. (1999). Utilization of bottom ash in pavement bases. Annual Meeting of Transportation Research Board, $30 \mathrm{p}$.

LEANDRO, R. P. (2002). Utilização das cinzas pesadas provenientes da queima do carvão mineral em diques de contenção: aspectos técnicos e ambientais. Trabalho de Final de Curso. Universidade do Sul de Santa Catarina, Tubarão, 143p.

LIMA, D.C. (1981). Algumas considerações relativas à aspectos da estabilização dos solos em particular à estabilização solo-cal. São Carlos. 171p. Dissertação (Mestrado). Escola de Engenharia de São Carlos. Universidade de São Paulo.

LOVELL, C. W.; KE, T. C.; HUANG, W. H.; LOVELL, J. E. (1991). Bottom ash as a highway material. Transportation Research Record, n. 1310, p. 106-116.

MAJIZADEH, K.; BOKOWSKI, G.; EL- MITINY, R. (1979). Material characteristics of power plant bottom ashes and their performance in bituminous mixtures: a laboratory investigation. Proceedings of the fifth International ash utilization symposium, Morgantown, West Virginia.

MOLINA, C. E. C. (2004). Estudo do comportamento mecânico de misturas de resíduo da fabricação de papel e solo para utilização na construção rodoviária. São Carlos. 131p. Dissertação (Mestrado). Escola de Engenharia de São Carlos. Universidade de São Paulo. 
MOORE, J. C.; JONES, R. L. (1971). Effect of soil surface area and extractable silica, alumina, and iron on lime stabilization characteristics of Illinois Soils. Highway Research Record, n. 351, p. 87 - 92.

MOULTON, L. K. (1973). Bottom ash and boiler slag. Proceedings of Third International Ash Utilization Symposium, Information Circular, Washington, DC. n. 8640 .

NARDI, J. V. (1988). Cinza: uma alternativa na construção de pavimentos noções gerais. Vigésima Terceira Reunião Anual de Pavimentação, Florianópolis, Santa Catarina, p. 287-309.

NEUBAUER, C. H.; THOMPSON, M. R. (1972). Stability properties of uncured lime-treated fine grained soils. Highway Research Record, n. 381, p. $20-26$.

NOGAMI, J. S.; VILLIBOR, D. F. (1995). Pavimentação de baixo custo com solos lateríticos. São Paulo. Editora Villibor. 213p.

NUNES, M. C. M.; DAWSON, A. R. (1997). Behavior of some pavement foundation materials under repeated loading. Transportation Research Record, n. 1577 , p. 1-9.

PANDEline, D. A.; CONSENTINO, P. J.; KALAJIAN, E. H.; CHAVEZ, M. F. (1997). Shear and deformation characteristics of municipal waste combustor bottom ash for highway applications. Transport Research Record, n. 1577, p. 101-108.

PARENTE, E. B. (2002). Avaliação do comportamento mecânico das misturas de solo-cimento e fosfogesso e cimento para uso na construção rodoviária. São Carlos. 120p. Dissertação (Mestrado). Escola de Engenharia de São Carlos. Universidade de São Paulo.

PAUTE, J. L.; DAWSON, A. R.; GALJAARD, P. J. (1996). Recommendations for repeated load triaxial test equipment and procedures for unbound granular 
materials. Proceedings European Symposium on Flexible Pavements, Rotterdam, Netherlands, p. 23-34.

PIAZZA, J. L.; RUI, V. (1999). Comportamento das cinzas pesadas de carvão mineral como substituto da areia quartzosa em argamassas. III Simpósio Brasileiro de Tecnologia das Argamassas, Vitória, Espírito Santo, p. 389-401.

POZZOBON, C. E. (1999). Aplicações tecnológicas para a cinza do carvão mineral produzida no complexo termelétrico Jorge Lacerda. Florianópolis. 122p. Dissertação (Mestrado). Universidade Federal de Santa Catarina.

RAMME, B.; THARANIYIL, M. (1999). Coal combustion products utilization handbook. Wisconsin Energy Company, p.

ROCHA, J. C. (2001). Aproveitamento de cinzas volantes e pesadas para a produção de concretos usinados, blocos e pavimentos de concretos. Relatório Final do Convênio GS-15/99 - Gerasul, Aneel, UFSC, Florianópolis, Santa Catarina, v. 1. 206 p.

ROCHA, J. C.; CHERIAF, M.; POZZOBON, C.; MAIA, M. S.; MAGRI, L.; XAVIER, S. M. T. (1999). Reaproveitamento das cinzas pesadas do Complexo Termelétrico Jorge Lacerda na elaboração de materiais de construção: aspectos tecnológicos e ambientais. Décimo Quinto Seminário Nacional de Produção e Transmissão de Energia Elétrica, Foz do Iguaçu, Paraná, p. 1-5.

SEALS, R. K.; MOULTON, L. K.; RUTH, B. E. (1972). An engineering material. Journal of Geotechnical Engineering. ASCE, v. 98, p. 311-325.

THOMPSON, M. R. (1966). Lime - Reactivity of Illinois soils. Journal of Soil Mechanics and Foundations Division, v. 92.

TORREY, S. (1978). Coal ash utilization - fly ash, bottom Ash and slag. New Jersey, Noyes Data Corporation. 370p. 
TRACTEBEL ENERGIA (2002). Fluxo Básico do Processo de Geração de Energia Térmica. Diretoria de Produção de Energia - Central de Manutenção de Serviços.

TRANSPORTATION RESEARCH BOARD, NATIONAL RESEARCH COUNCIL (1987). State of the art 5 - Lime stabilization reactions, properties, design and construction. Washington D. C.

USMEN, M. A.; HEAD, W. J.; MOULTON, L. K. (1983). Use of coal-associated waste in low-volume roads. Transport Research Record, n. 898, p. 268-277.

ZHANG, X.; GRESS, D.; KARPINSKI, S.; EIGHMY, T. (1999). Utilization of municipal solid waste combustion bottom ash as a paving material. Transport Research Record, n. 1652, p. 257-263. 


\section{BIBLIOGRAFIA CONSULTADA}

ABITANTE, E. (1997). Proposta metodológica de mapeamento geotécnico com uso de pedologia em solos tropicais visando obras rodoviárias. Florianópolis. 138p. Dissertação (Mestrado). Universidade Federal de Santa Catarina.

AGÊNCIA NACIONAL DE ENERGIA ELÉTRICA (2002). Atlas de energia elétrica do Brasil. $1^{a}$ edição. Brasília. 153p.

ANDERSON, D. A.; USMEN, M.; MOULTON, L. K. (1976). Use of power plant aggregate in bituminous construction. Transport Research Record, n. 595, p. 18 $-24$.

ANTUNES, F. D. S. (2003). O uso da pedologia na engenharia. Segundo colóquio de solos tropicais e subtropicais e suas aplicações em engenharia civil. Porto Alegre. 164p.

BARROS, C. O. A. (2003). Revisão da correlação mini-CBR/CBR para solos do município de São Carlos - SP. São Carlos. 110p. Dissertação (Mestrado). Escola de Engenharia de São Carlos. Universidade de São Paulo.

DESCHAMPS, R. J. (1998). Using FBC stoker ashes as roadway fill: a case study. Journal of Geotechinical and Geoenviromental Engineering, p. 1120 1127.

FABER, J. H.; DIGIOIA, A. M. (1976). Use of ash in embankment construction. Transport Research Record, n. 593, p. 13 -19. 
GOMES, A. J. P. (2002). Carvão do Brasil - Turfa agrícola - geologia, meio ambiente e participação estratégica na produção de eletricidade no sul do Brasil. Porto Alegre, EST edições. 164p.

KOBAYASHI, A. R. K. (2000). Avaliação da influência do tipo de cimento na expansibilidade de misturas de fosfogesso e cimento. São Carlos. 112p. Dissertação (Mestrado). Escola de Engenharia de São Carlos. Universidade de São Paulo.

KNIESS, C. T.; KUHNEN, N. C.; RIELLA, H. G.; NEVES, E.; BORBA, C. D. G. (2002). Estudo do efeito da quantidade de óxido de ferro em cinzas pesadas de carvão mineral na obtenção de vitrocerâmicos. Química Nova, n. 6, p. 926 930.

LEWIS, T. S. (1976). Construction of fly ash roadway embankment in Illinois. Transport Research Record, n. 593, p. 20 -24.

NEVILLE, A. M. (1997). Propriedades do concreto. $2^{a}$ ed. São Paulo, PINI. $828 p$.

ORTIZ, J. A. (1997). Estudo de misturas de solo e fosfogesso com a sua utilização em rodovias. São Carlos. 179p. Dissertação (Mestrado). Escola de Engenharia de São Carlos. Universidade de São Paulo.

PAVLOVICH, R. D.; LENTZ, H. J.; ORMSBY, W. C. (1979). Incinerator residue as aggregate for hot-mix asphalt base course. Transport Research Record, $\mathrm{n}$. 734 , p. $38-44$.

PRADO, H. D. (1996). Manual de classificação de solos do Brasil. $3^{a}$ edição. Jaboticabal, FUNEP. 194p.

PRADO, H. D. (2003). Solos do Brasil. $3^{a}$ edição revisada e ampliada. Piracicaba, $275 p$. 
SIKES, F. P. G.; KPLBECK, M. H. J. (1973). Disposal and uses of power plant ash in urban area. Journal of the Power Division. Proceedings of the American Society of Civil Engineers, n. P01, p. $217-235$.

SILVESTRE JÚNIOR, O. B. (2002). Fosfogesso estabilizado com cimento para aplicação na construção rodoviária: a influência do tipo de cimento na resistência e deformabilidade da mistura. São Carlos. 141p. Dissertação (Mestrado). Escola de Engenharia de São Carlos. Universidade de São Paulo.

TAKEDA, M. C. (1998). Avaliação das propriedades mecânicas de misturas de fosfogesso e cimento para uso na construção rodoviária. São Carlos. 179p. Dissertação (Mestrado). Escola de Engenharia de São Carlos. Universidade de São Paulo.

TRACTEBEL ENERGIA (2002). Relatório gerencial. Diretoria de produção de energia. 141p.

USMEN, M.; ANDERSON, D. A.; MOULTON, L. K. (1978). Applicability of conventional test methods and material specifications to coal-associated waste aggregates. Transport Research Record, n. 691, p. $49-57$. 


\section{ANEXO A ENSAIOS DE MINI-CBR}


$\mathrm{TMA}_{00}$
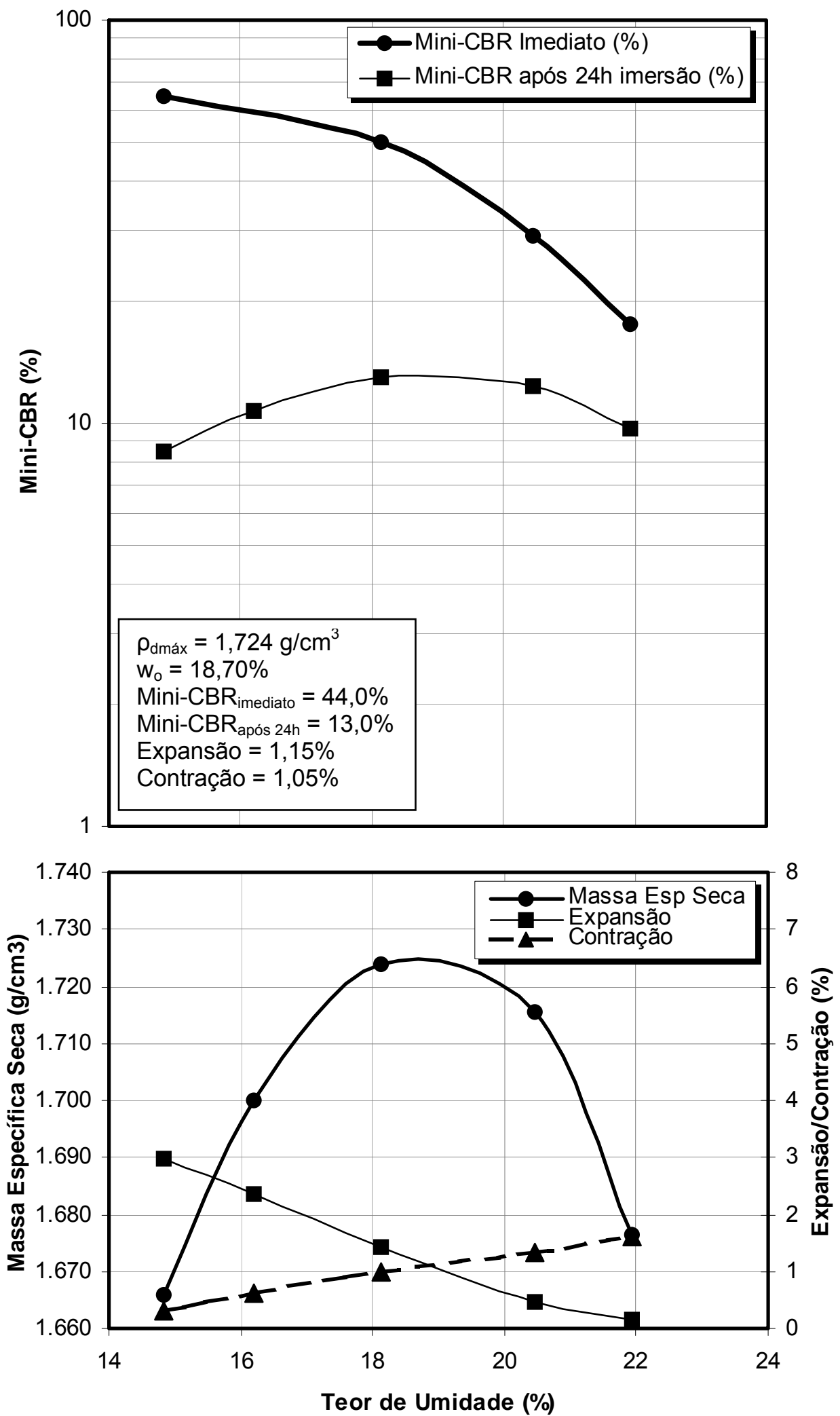
$\mathrm{TMA}_{25}$
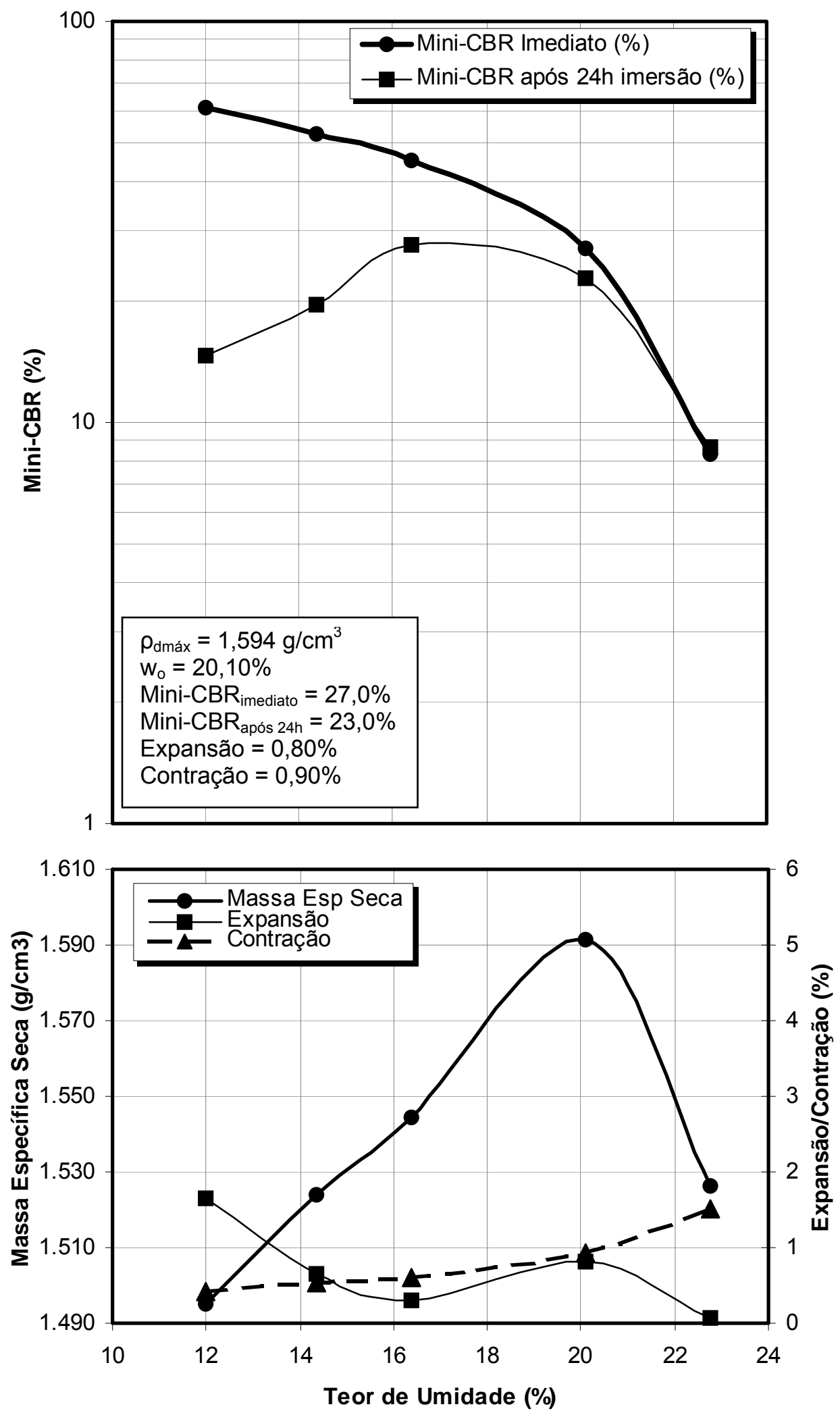
$\mathrm{TMA}_{35}$
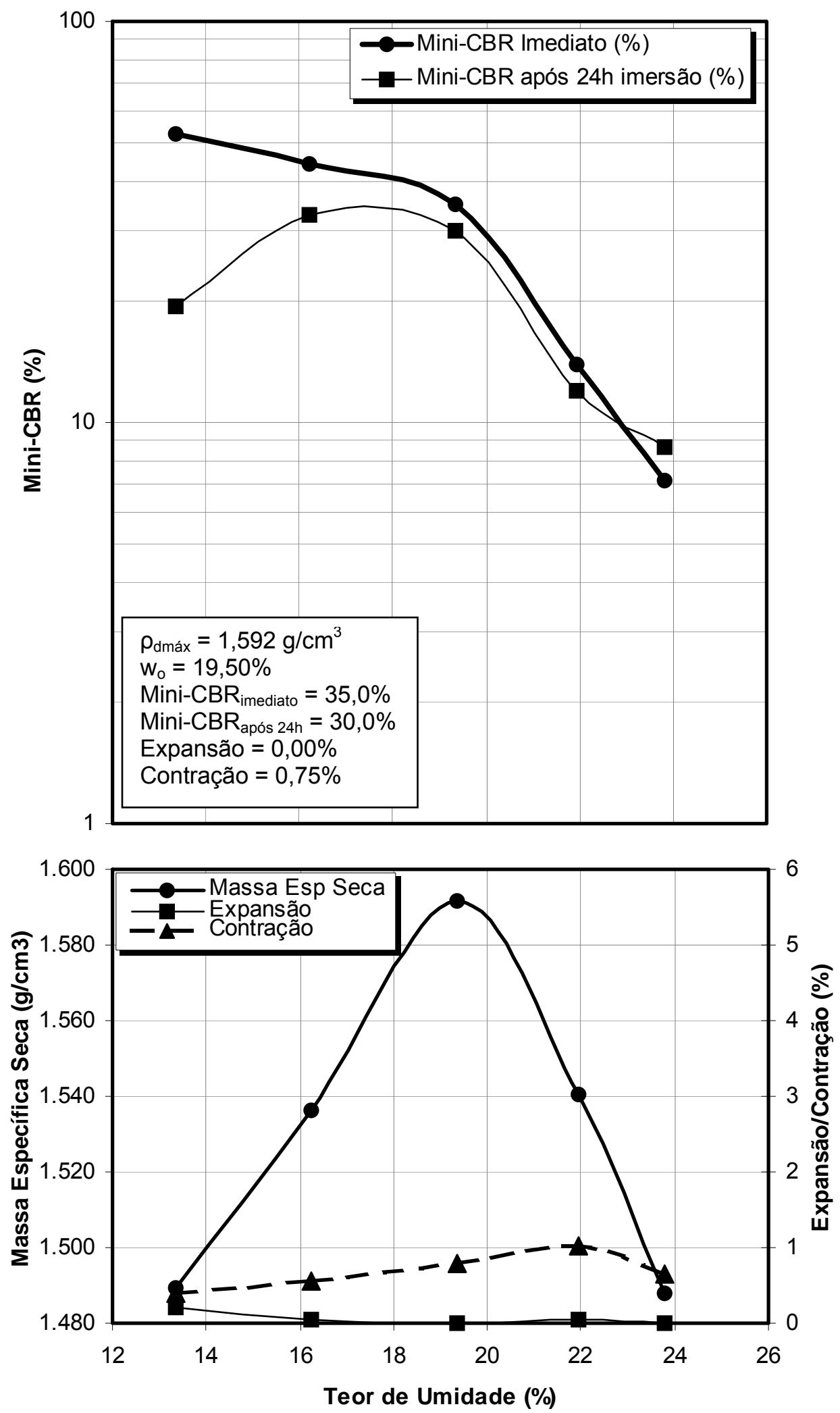
$\mathrm{TMA}_{45}$
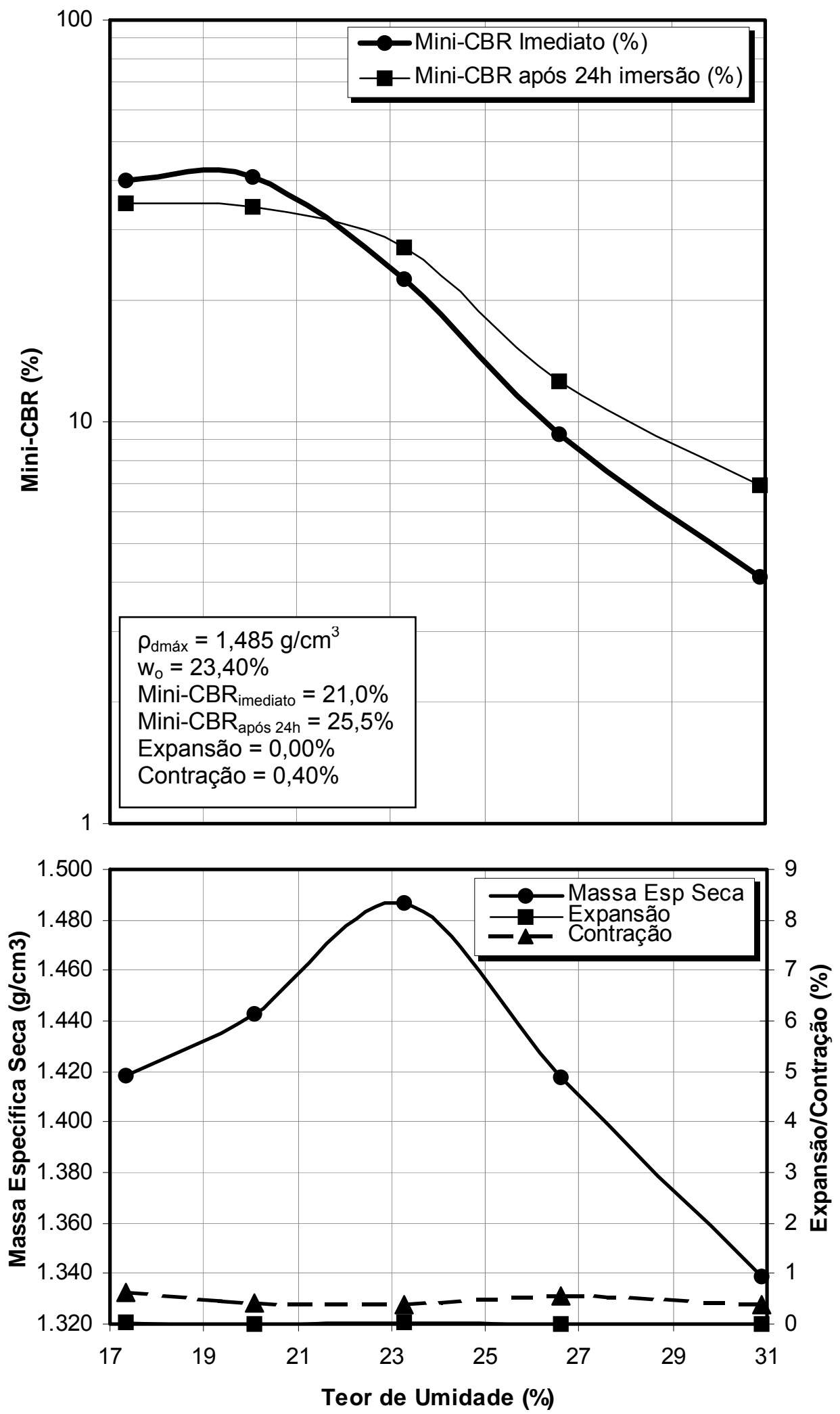


\section{$J_{G A} A_{00}$}
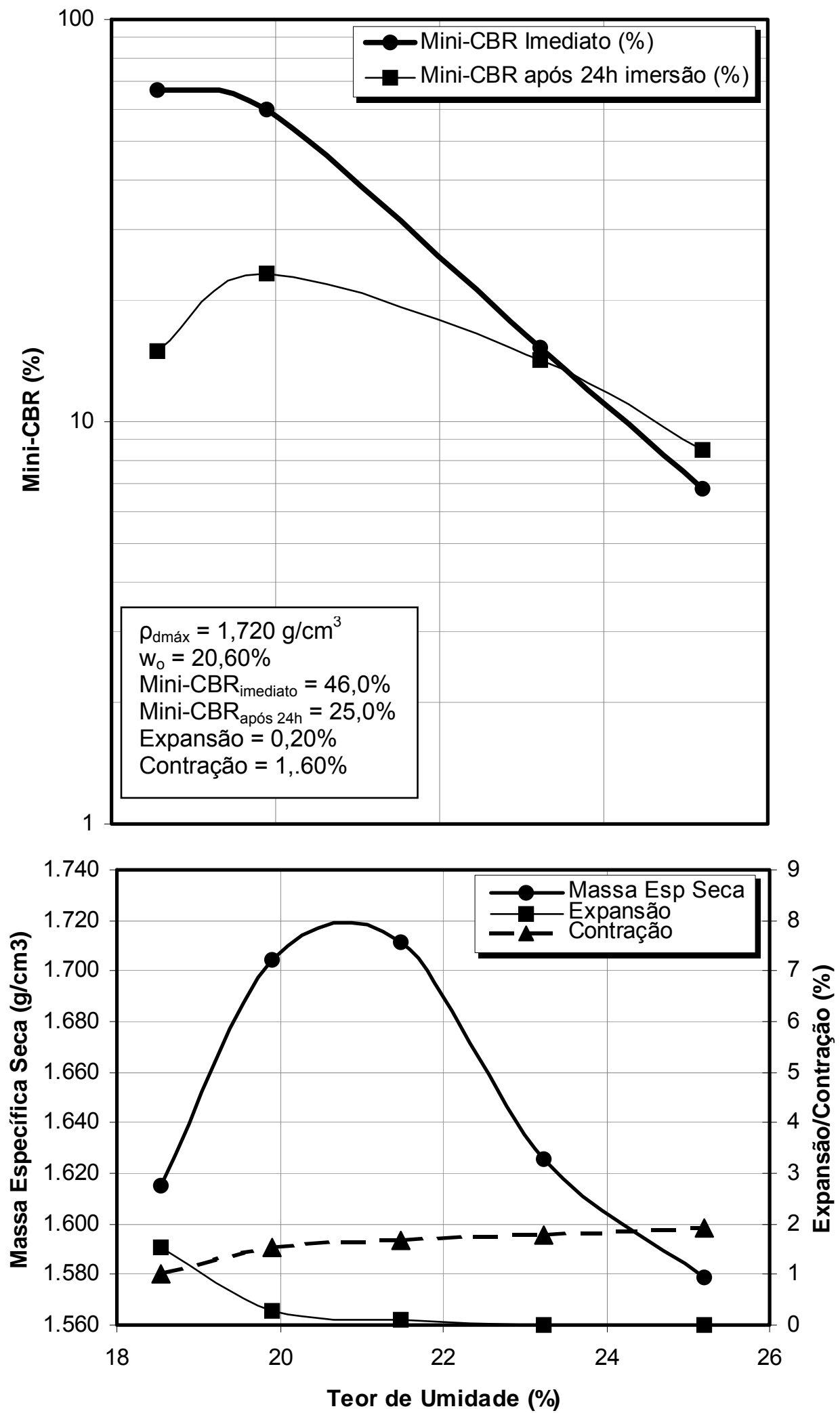
$J_{G A}$
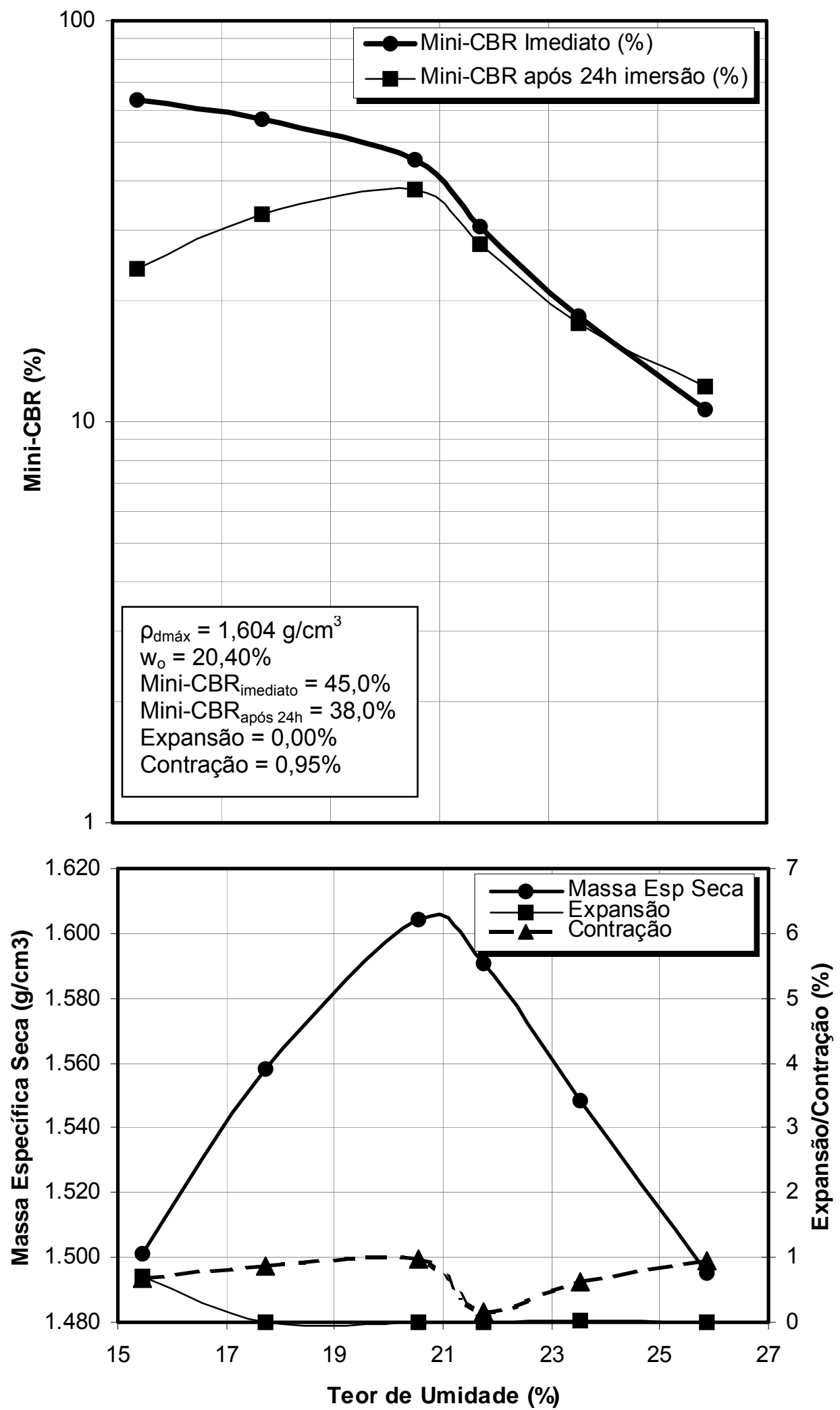
$\mathrm{JGA}_{35}$
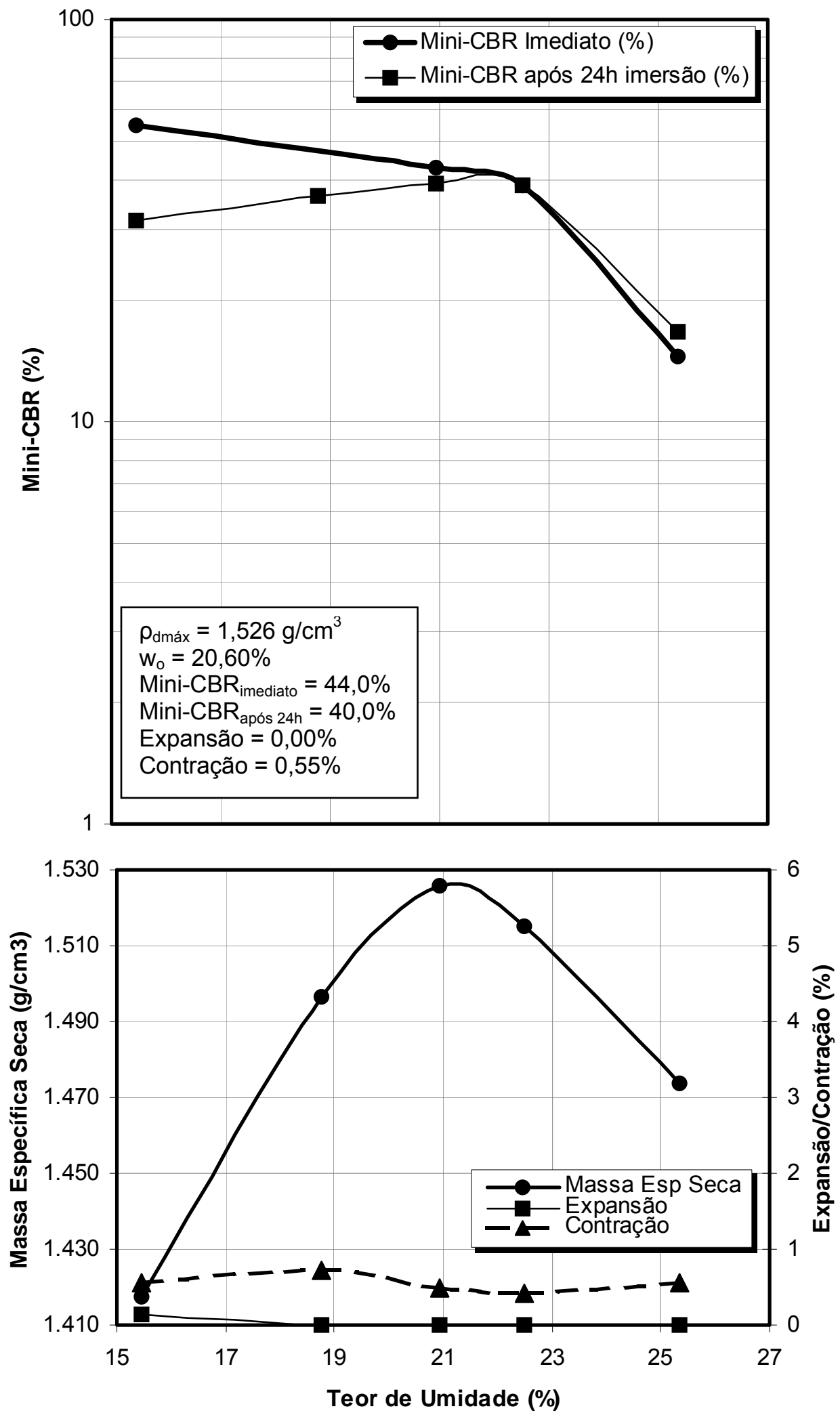
$J_{G A}$
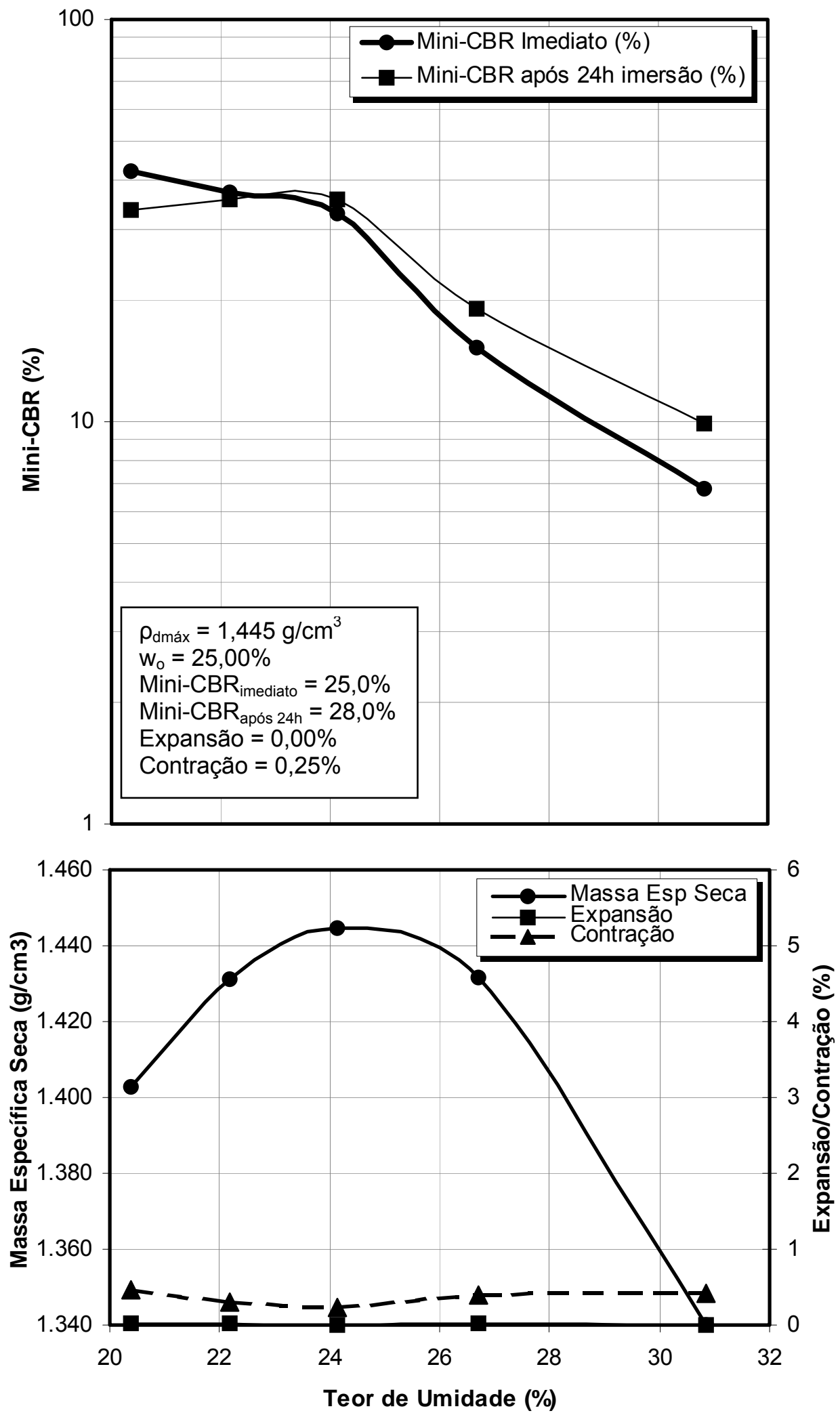

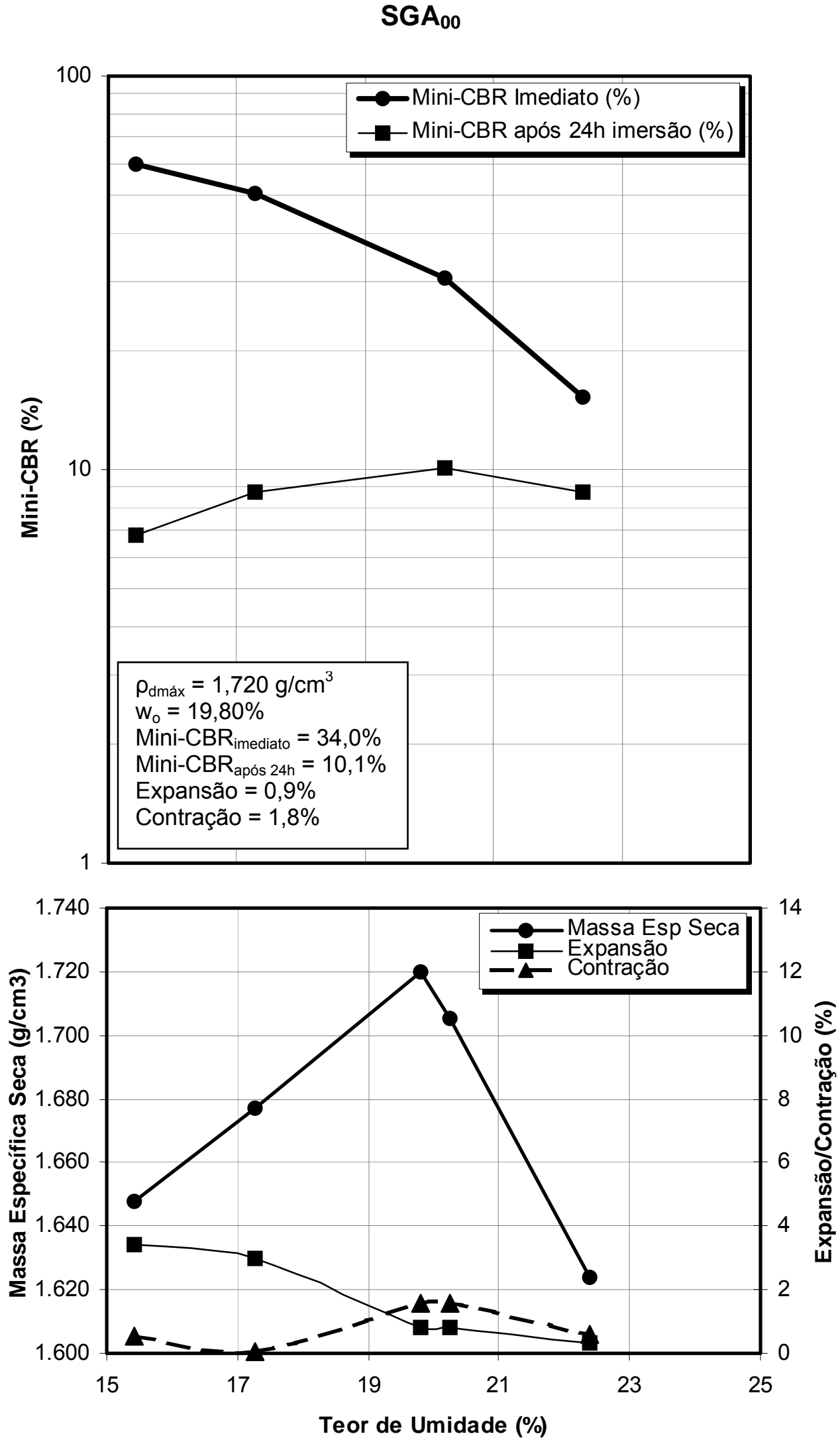

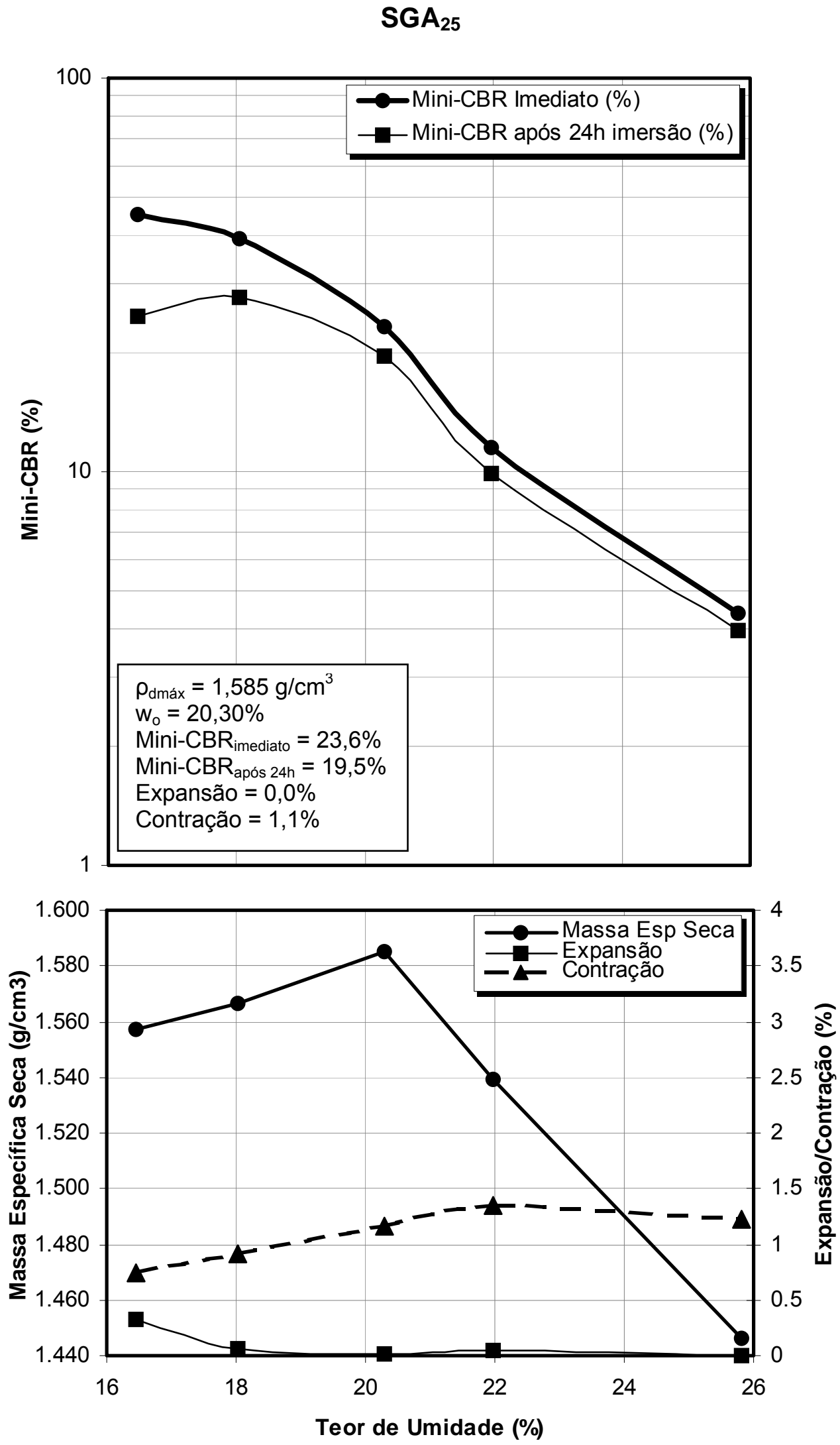
$\mathrm{SGA}_{35}$
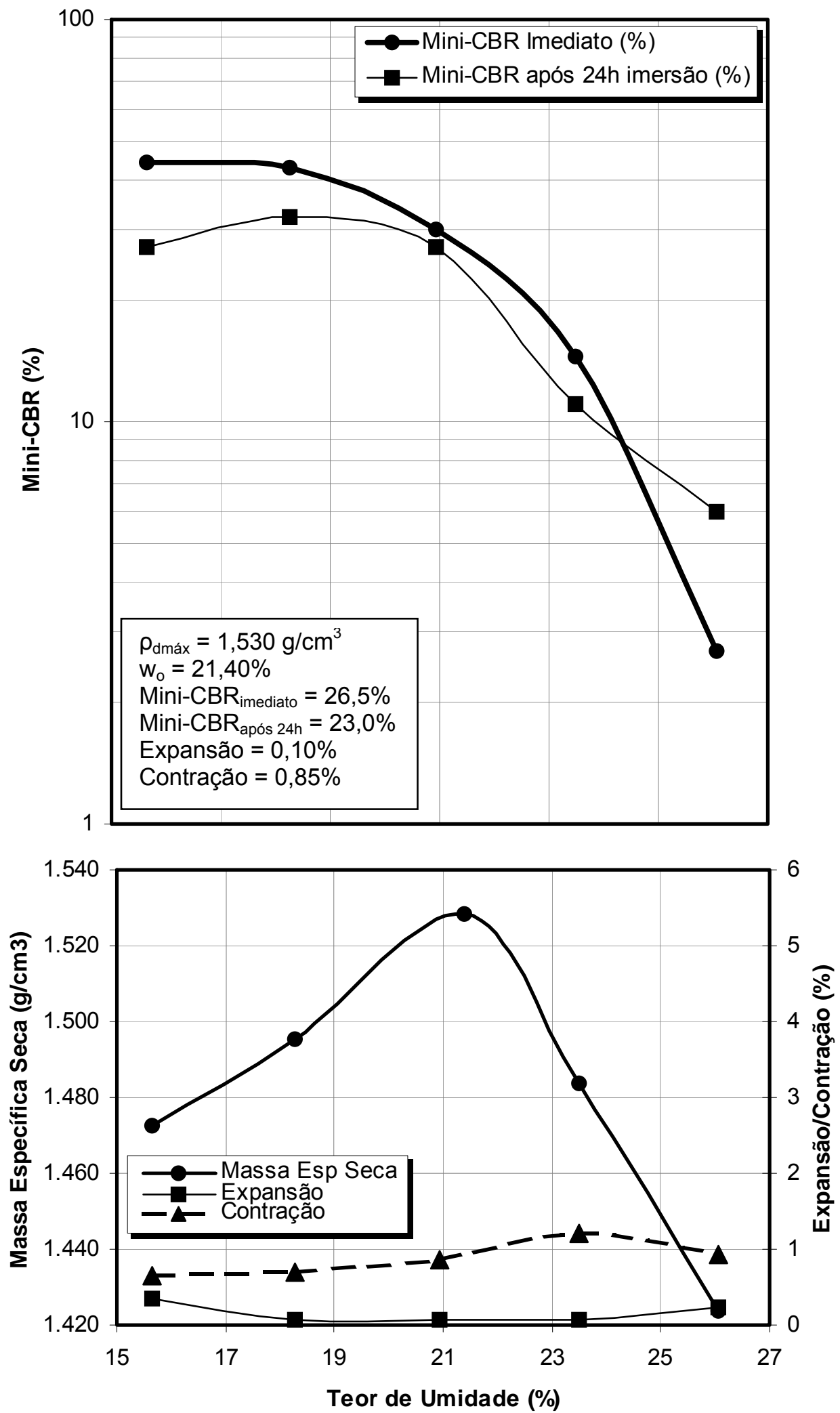


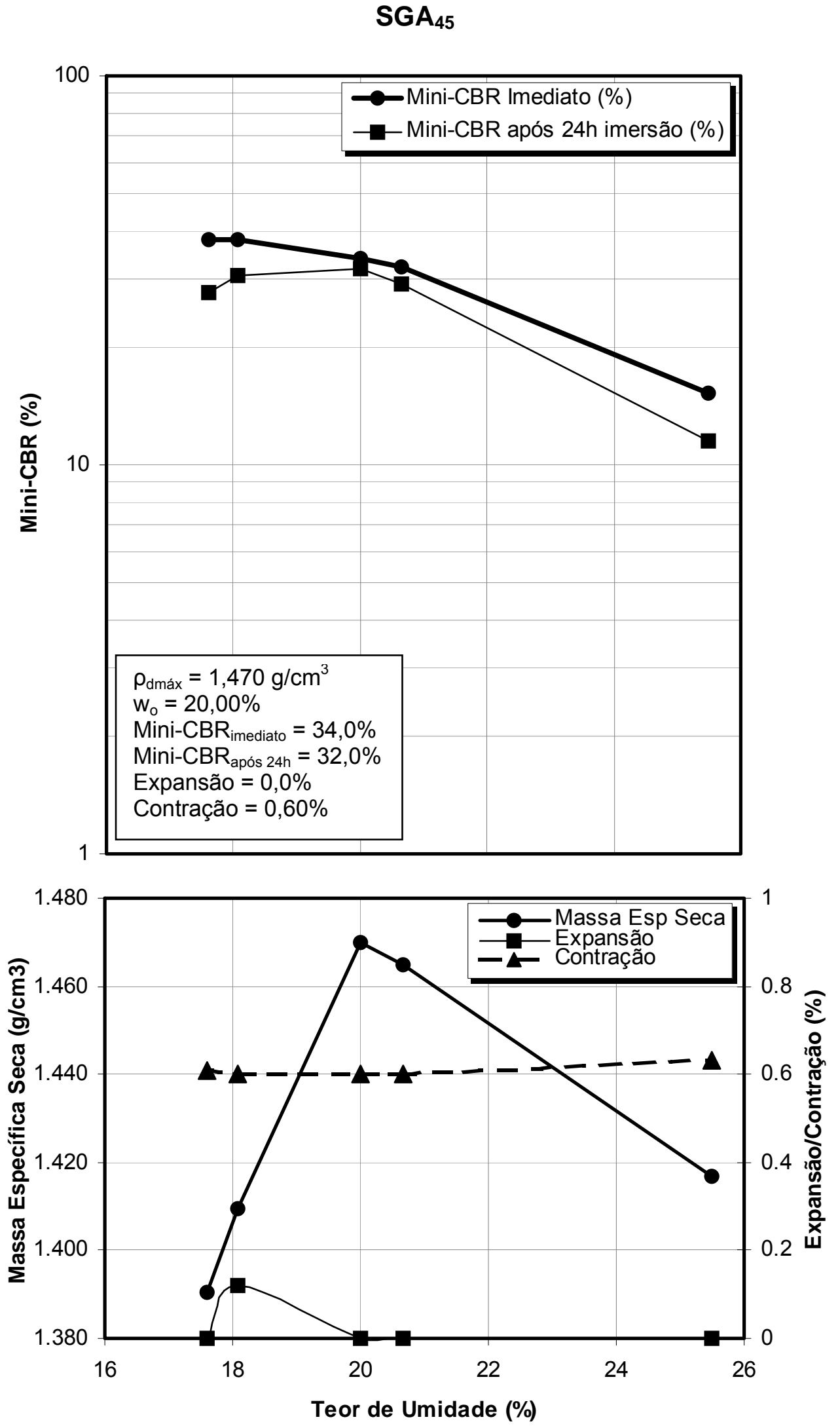




\section{ANEXO B \\ RESULTADOS DOS ENSAIOS DE RESISTÊNCIA À COMPRESSÃO SIMPLES}



TABELA B2 - Valores de resistência à compressão simples das misturas solo-cinza pesada-cal e identificação dos outliers.

\begin{tabular}{|c|c|c|c|c|c|c|c|c|c|c|c|c|c|c|c|}
\hline \multirow[b]{2}{*}{ Solo } & \multirow[b]{2}{*}{$\begin{array}{l}\text { Cura } \\
\text { (dias) }\end{array}$} & \multicolumn{3}{|c|}{ Misutras } & \multicolumn{3}{|c|}{ Corpo-de-prova } & \multirow[b]{2}{*}{$\begin{array}{c}\text { Média } \\
\text { (kPa) }\end{array}$} & \multirow[b]{2}{*}{$\begin{array}{l}\text { Desvio } \\
\text { Padrão }\end{array}$} & \multirow[b]{2}{*}{ G Maior } & \multirow[b]{2}{*}{ G Menor } & \multirow[b]{2}{*}{ G Crítico } & \multirow[b]{2}{*}{ Y Maior } & \multirow[b]{2}{*}{ Y menor } & \multirow[b]{2}{*}{$\begin{array}{l}\text { Média Adotada } \\
\qquad(\mathrm{kPa})\end{array}$} \\
\hline & & $\begin{array}{l}\text { Solo } \\
(\%)\end{array}$ & $\begin{array}{c}\text { Cinza } \\
(\%)\end{array}$ & $\begin{array}{l}\text { Cal } \\
(\%)\end{array}$ & $\begin{array}{c}1 \\
(\mathrm{kPa}) \\
\end{array}$ & $\begin{array}{c}2 \\
(\mathrm{kPa})\end{array}$ & $\begin{array}{c}3 \\
(\mathrm{kPa})\end{array}$ & & & & & & & & \\
\hline \multirow{12}{*}{ JG } & $\overline{0}$ & 97 & 0 & 3 & 1343.32 & 1318.98 & 1401.84 & 1354.71 & 42.59 & 1.11 & 0.84 & 1.00 & 1397.30 & 1312.12 & 1331.15 \\
\hline & 0 & 75 & 22 & 3 & 616.66 & 623.39 & 653.24 & 631.10 & 19.47 & 1.14 & 0.74 & 1.00 & 650.57 & 611.63 & 620.03 \\
\hline & 0 & 65 & 32 & 3 & 683.44 & 640.76 & 586.09 & 636.76 & 48.80 & 0.96 & 1.04 & 1.00 & 685.56 & 587.97 & 662.10 \\
\hline & 0 & 55 & 42 & 3 & 313.08 & 294.80 & 295.23 & 301.04 & 10.43 & 1.15 & 0.60 & 1.00 & 311.47 & 290.60 & 295.02 \\
\hline & 28 & 97 & 0 & 3 & 2200.00 & 1875.04 & 2136.76 & 2070.60 & 172.29 & 0.75 & 1.14 & 1.00 & 2242.89 & 1898.31 & 2168.38 \\
\hline & 28 & 75 & 22 & 3 & 1334.78 & 1340.66 & 1332.70 & 1336.05 & 4.13 & 1.12 & 0.81 & 1.00 & 1340.18 & 1331.92 & 1333.74 \\
\hline & 28 & 65 & 32 & 3 & 1091.07 & 1014.75 & 959.84 & 1021.89 & 65.91 & 1.05 & 0.94 & 1.00 & 1087.79 & 955.98 & 987.30 \\
\hline & 28 & 55 & 42 & 3 & 509.59 & 604.15 & 556.69 & 556.81 & 47.28 & 1.00 & 1.00 & 1.00 & 604.09 & 509.53 & 556.81 \\
\hline & 84 & 97 & 0 & 3 & 2450.00 & 2600.00 & 2555.00 & 2535.00 & 76.97 & 0.84 & 1.10 & 1.00 & 2611.97 & 2458.03 & 2577.50 \\
\hline & 84 & 75 & 22 & 3 & 1764.00 & 1779.00 & 1801.00 & 1781.33 & 18.61 & 1.06 & 0.93 & 1.00 & 1799.94 & 1762.72 & 1771.50 \\
\hline & 84 & 65 & 32 & 3 & 1360.00 & 1368.00 & 1371.00 & 1366.33 & 5.69 & 0.82 & 1.11 & 1.00 & 1372.02 & 1360.65 & 1369.50 \\
\hline & 84 & 55 & 42 & 3 & 750.00 & 754.00 & 900.00 & 801.33 & 85.47 & 1.15 & 0.60 & 1.00 & 886.80 & 715.86 & 752.00 \\
\hline \multirow{12}{*}{ SG } & 0 & 97 & 0 & 3 & 1403.91 & 1372.78 & 1328.12 & 1368.27 & 38.10 & 0.94 & 1.05 & 1.00 & 1406.37 & 1330.17 & 1388.35 \\
\hline & 0 & 75 & 22 & 3 & 634.72 & 651.62 & 692.25 & 659.53 & 29.57 & 1.11 & 0.84 & 1.00 & 689.10 & 629.96 & 643.17 \\
\hline & 0 & 65 & 32 & 3 & 507.89 & 508.41 & 508.75 & 508.35 & 0.43 & 0.92 & 1.06 & 1.00 & 508.78 & 507.92 & 508.58 \\
\hline & 0 & 55 & 42 & 3 & 440.18 & 443.94 & 439.42 & 441.18 & 2.42 & 1.14 & 0.73 & 1.00 & 443.60 & 438.76 & 439.80 \\
\hline & 28 & 97 & 0 & 3 & 1482.80 & 1619.74 & 1692.00 & 1598.18 & 106.25 & 0.88 & 1.09 & 1.00 & 1704.43 & 1491.93 & 1655.87 \\
\hline & 28 & 75 & 22 & 3 & 1098.91 & 1013.48 & 1045.76 & 1052.72 & 43.14 & 1.07 & 0.91 & 1.00 & 1095.85 & 1009.58 & 1029.62 \\
\hline & 28 & 65 & 32 & 3 & 631.07 & 642.93 & 650.50 & 641.50 & 9.79 & 0.92 & 1.06 & 1.00 & 651.29 & 631.71 & 646.72 \\
\hline & 28 & 55 & 42 & 3 & 742.46 & 783.95 & 812.38 & 779.60 & 35.16 & 0.93 & 1.06 & 1.00 & 814.76 & 744.43 & 798.17 \\
\hline & 84 & 97 & 0 & 3 & 1940.57 & 1800.11 & 1825.41 & 1855.36 & 74.87 & 1.14 & 0.74 & 1.00 & 1930.23 & 1780.50 & 1812.76 \\
\hline & 84 & 75 & 22 & 3 & 1276.81 & 1279.22 & 1278.03 & 1278.02 & 1.21 & 1.00 & 1.00 & 1.00 & 1279.23 & 1276.81 & 1278.02 \\
\hline & 84 & 65 & 32 & 3 & 872.64 & 864.28 & 863.33 & 866.75 & 5.12 & 1.15 & 0.67 & 1.00 & 871.87 & 861.63 & 863.81 \\
\hline & 84 & 55 & 42 & 3 & 1029.33 & 1022.13 & 1027.55 & 1026.34 & 3.75 & 0.80 & 1.12 & 1.00 & 1030.09 & 1022.59 & 1028.44 \\
\hline \multirow{12}{*}{ TM } & 0 & 97 & 0 & 3 & 1470.23 & 1393.53 & 1557.72 & 1473.83 & 82.15 & 1.02 & 0.98 & 1.00 & 1555.98 & 1391.67 & 1431.88 \\
\hline & 0 & 75 & 22 & 3 & 577.38 & 570.74 & 571.39 & 573.17 & 3.66 & 1.15 & 0.66 & 1.00 & 576.83 & 569.51 & 571.07 \\
\hline & 0 & 65 & 32 & 3 & 601.65 & 599.30 & 559.79 & 586.91 & 23.52 & 0.63 & 1.15 & 1.00 & 610.43 & 563.39 & 600.48 \\
\hline & 0 & 55 & 42 & 3 & 230.95 & 233.08 & 249.36 & 237.80 & 10.07 & 1.15 & 0.68 & 1.00 & 247.87 & 227.73 & 232.02 \\
\hline & 28 & 97 & 0 & 3 & 1430.91 & 1350.92 & 1478.43 & 1420.09 & 64.44 & 0.91 & 1.07 & 1.00 & 1484.53 & 1355.65 & 1454.67 \\
\hline & 28 & 75 & 22 & 3 & 853.26 & 844.36 & 771.21 & 822.94 & 45.02 & 0.67 & 1.15 & 1.00 & 867.97 & 777.92 & 848.81 \\
\hline & 28 & 65 & 32 & 3 & 977.98 & 944.50 & 995.20 & 972.56 & 25.78 & 0.88 & 1.09 & 1.00 & 998.34 & 946.78 & 986.59 \\
\hline & 28 & 55 & 42 & 3 & 384.32 & 416.41 & 427.97 & 409.57 & 22.62 & 0.81 & 1.12 & 1.00 & 432.18 & 386.95 & 422.19 \\
\hline & 84 & 97 & 0 & 3 & 1610.00 & 1611.00 & 1609.00 & 1610.00 & 1.00 & 1.00 & 1.00 & 1.00 & 1611.00 & 1609.00 & 1610.00 \\
\hline & 84 & 75 & 22 & 3 & 990.09 & 1002.00 & 992.09 & 994.73 & 6.38 & 1.14 & 0.73 & 1.00 & 1001.10 & 988.35 & 991.09 \\
\hline & 84 & 65 & 32 & 3 & 1215.32 & 1210.00 & 1216.74 & 1214.02 & 3.55 & 0.77 & 1.13 & 1.00 & 1217.57 & 1210.47 & 1216.03 \\
\hline & 84 & 55 & 42 & 3 & 560.00 & 558.00 & 556.00 & 558.00 & 2.00 & 1.00 & 1.00 & 1.00 & 560.00 & 556.00 & 558.00 \\
\hline
\end{tabular}




\section{ANEXO C RESULTADOS DE MÓDULO TANGENTE INICIAL}


TABELA C1 - Valores de módulo tangente inicial das misturas solo-cinza.

\begin{tabular}{|c|c|c|c|c|c|c|c|c|}
\hline \multirow[b]{2}{*}{ Solo } & \multirow[b]{2}{*}{$\begin{array}{c}\text { Cura } \\
\text { (dias) }\end{array}$} & \multicolumn{3}{|c|}{ Misutras } & \multicolumn{3}{|c|}{ Corpo-de-prova } & \multirow[b]{2}{*}{$\begin{array}{l}\text { Média } \\
\text { (MPa) }\end{array}$} \\
\hline & & $\begin{array}{l}\text { Solo } \\
(\%)\end{array}$ & $\begin{array}{c}\text { Cinza } \\
(\%)\end{array}$ & $\begin{array}{l}\text { Cal } \\
(\%)\end{array}$ & $\begin{array}{c}1 \\
(\mathrm{MPa})\end{array}$ & $\begin{array}{c}2 \\
(\mathrm{MPa})\end{array}$ & $\begin{array}{c}3 \\
(\mathrm{MPa})\end{array}$ & \\
\hline \multirow{12}{*}{ JG } & 0 & 100 & 0 & 0 & 125.00 & 168.00 & 7 & 147 \\
\hline & 0 & 75 & 25 & 0 & 20.00 & 24.00 & * & 22 \\
\hline & 0 & 65 & 35 & 0 & 34.00 & 30.00 & 27.00 & 32 \\
\hline & 0 & 55 & 45 & 0 & 6.00 & 6.00 & 6.00 & 6 \\
\hline & 28 & 100 & 0 & $\overline{0}$ & 145.00 & 179.00 & 203.00 & 162 \\
\hline & 28 & 75 & 25 & 0 & 36.00 & 53.00 & 48.00 & 42 \\
\hline & 28 & 65 & 35 & 0 & 29.00 & 34.00 & 32.00 & 33 \\
\hline & 28 & 55 & 45 & 0 & 11.00 & 6.00 & * & 9 \\
\hline & 84 & 100 & $\overline{0}$ & $\overline{0}$ & 187.00 & 123.00 & * & 155 \\
\hline & 84 & 75 & 25 & 0 & 39.00 & 51.00 & 42.00 & 45 \\
\hline & 84 & 65 & 35 & 0 & 35.00 & 38.00 & 38.00 & 38 \\
\hline & 84 & 55 & 45 & 0 & 15.00 & 14.00 & * & 15 \\
\hline \multirow{12}{*}{ SG } & 0 & 100 & 0 & 0 & 50.00 & 50.00 & n & 50 \\
\hline & 0 & 75 & 25 & 0 & 8.00 & 8.00 & 8.00 & 8 \\
\hline & 0 & 65 & 35 & 0 & 4.00 & 5.00 & 4.00 & 5 \\
\hline & 0 & 55 & 45 & 0 & 11.00 & 9.00 & 10.00 & 10 \\
\hline & 28 & 100 & 0 & 0 & 73.00 & 63.00 & 71.00 & 67 \\
\hline & 28 & 75 & 25 & 0 & 9.00 & 10.00 & 11.00 & 10 \\
\hline & 28 & 65 & 35 & 0 & 10.00 & 6.00 & 4.00 & 7 \\
\hline & 28 & 55 & 45 & 0 & 14.00 & 15.00 & 13.00 & 14 \\
\hline & 84 & 100 & 0 & 0 & 20.00 & 51.00 & 51.00 & 51 \\
\hline & 84 & 75 & 25 & 0 & 8.00 & 7.00 & 10.00 & 8 \\
\hline & 84 & 65 & 35 & 0 & 4.00 & 6.00 & 3.00 & 4 \\
\hline & 84 & 55 & 45 & 0 & 20.00 & 23.00 & 21.00 & 21 \\
\hline \multirow{12}{*}{ TM } & 0 & 100 & 0 & 0 & 79.00 & 68.00 & 92.00 & 80 \\
\hline & 0 & 75 & 25 & 0 & 7.00 & 4.00 & 4.00 & 4 \\
\hline & 0 & 65 & 35 & 0 & 4.00 & 4.00 & 3.00 & 4 \\
\hline & 0 & 55 & 45 & 0 & 5.00 & 6.00 & 6.00 & 6 \\
\hline & 28 & 100 & 0 & 0 & 128.00 & 131.00 & 128.00 & 130 \\
\hline & 28 & 75 & 25 & 0 & 9.00 & 7.00 & 9.00 & 9 \\
\hline & 28 & 65 & 35 & 0 & 10.00 & 10.00 & 8.00 & 9 \\
\hline & 28 & 55 & 45 & 0 & 4.00 & 4.00 & 4.00 & 4 \\
\hline & 84 & 100 & 0 & 0 & 48.00 & 42.00 & 106.00 & 77 \\
\hline & 84 & 75 & 25 & 0 & 8.00 & 8.00 & 8.00 & 8 \\
\hline & 84 & 65 & 35 & 0 & 8.00 & 4.00 & 8.00 & 8 \\
\hline & 84 & 55 & 45 & 0 & 5.00 & 4.00 & 4.00 & 4 \\
\hline
\end{tabular}

Outliers determinados para os corpos-de-prova dos ensaios de RCS. 
TABELA C2 - Valores de módulo tangente inicial das misturas solo-cinza-cal.

\begin{tabular}{|c|c|c|c|c|c|c|c|c|}
\hline \multirow[b]{2}{*}{ Solo } & \multirow[b]{2}{*}{$\begin{array}{l}\text { Cura } \\
\text { (dias) }\end{array}$} & \multicolumn{3}{|c|}{ Misutras } & \multicolumn{3}{|c|}{ Corpo-de-prova } & \multirow[b]{2}{*}{$\begin{array}{l}\text { Média } \\
(\mathrm{kPa})\end{array}$} \\
\hline & & $\begin{array}{l}\text { Solo } \\
(\%)\end{array}$ & $\begin{array}{c}\text { Cinza } \\
(\%)\end{array}$ & $\begin{array}{l}\text { Cal } \\
(\%)\end{array}$ & $\begin{array}{c}1 \\
(\mathrm{kPa})\end{array}$ & $\begin{array}{c}2 \\
(\mathrm{kPa})\end{array}$ & $\begin{array}{c}3 \\
(\mathrm{kPa})\end{array}$ & \\
\hline \multirow{12}{*}{ JG } & 0 & 97 & 0 & 3 & 57.00 & 60.00 & 60.00 & 59 \\
\hline & 0 & 75 & 22 & 3 & 13.00 & 13.00 & 13.00 & 13 \\
\hline & 0 & 65 & 32 & 3 & 42.00 & 42.00 & 42.00 & 42 \\
\hline & 0 & 55 & 42 & 3 & 7.00 & 7.00 & 7.00 & 7 \\
\hline & 28 & 97 & 0 & 3 & 170.00 & 170.00 & 170.00 & 170 \\
\hline & 28 & 75 & 22 & 3 & 79.00 & 77.00 & 84.00 & 82 \\
\hline & 28 & 65 & 32 & 3 & 65.00 & 72.00 & 72.00 & 72 \\
\hline & 28 & 55 & 42 & 3 & 12.00 & 23.00 & 23.00 & 19 \\
\hline & 84 & 97 & 0 & 3 & 221.00 & 197.00 & 195.00 & 196 \\
\hline & 84 & 75 & 22 & 3 & 131.00 & 125.00 & 140.00 & 128 \\
\hline & 84 & 65 & 32 & 3 & 112.00 & 115.00 & 109.00 & 112 \\
\hline & 84 & 55 & 42 & 3 & 40.00 & 37.00 & 33.00 & 39 \\
\hline \multirow{12}{*}{ SG } & 0 & 97 & 0 & 3 & 52.00 & 53.00 & 50.00 & 53 \\
\hline & 0 & 75 & 22 & 3 & 13.00 & 13.00 & 13.00 & 13 \\
\hline & 0 & 65 & 32 & 3 & 12.00 & 12.00 & 12.00 & 12 \\
\hline & 0 & 55 & 42 & 3 & 14.00 & 14.00 & 14.00 & 14 \\
\hline & 28 & 97 & 0 & 3 & 186.00 & 124.00 & 156.00 & 140 \\
\hline & 28 & 75 & 22 & 3 & 34.00 & 34.00 & 34.00 & 34 \\
\hline & 28 & 65 & 32 & 3 & 12.00 & 12.00 & 12.00 & 12 \\
\hline & 28 & 55 & 42 & 3 & 49.00 & 46.00 & 46.00 & 46 \\
\hline & 84 & 97 & 0 & 3 & 185.00 & 152.00 & 153.00 & 153 \\
\hline & 84 & 75 & 22 & 3 & 60.00 & 58.00 & 57.00 & 58 \\
\hline & 84 & 65 & 32 & 3 & 18.00 & 19.00 & 19.00 & 19 \\
\hline & 84 & 55 & 42 & 3 & 71.00 & 73.00 & 74.00 & 73 \\
\hline \multirow{12}{*}{ TM } & 0 & 97 & 0 & 3 & 74.00 & 126.00 & 126.00 & 100 \\
\hline & 0 & 75 & 22 & 3 & 15.00 & 15.00 & 15.00 & 15 \\
\hline & 0 & 65 & 32 & 3 & 11.00 & 11.00 & 11.00 & 11 \\
\hline & 0 & 55 & 42 & 3 & 4.00 & 4.00 & 4.00 & 4 \\
\hline & 28 & 97 & 0 & 3 & 202.00 & 193.00 & 192.00 & 197 \\
\hline & 28 & 75 & 22 & 3 & 49.00 & 49.00 & 49.00 & 49 \\
\hline & 28 & 65 & 32 & 3 & 29.00 & 31.00 & 34.00 & 32 \\
\hline & 28 & 55 & 42 & 3 & 5.00 & 5.00 & 6.00 & 6 \\
\hline & 84 & 97 & 0 & 3 & 212.00 & 213.00 & 213.00 & 213 \\
\hline & 84 & 75 & 22 & 3 & 75.00 & 80.00 & 77.00 & 76 \\
\hline & 84 & 65 & 32 & 3 & 69.00 & 75.00 & 74.00 & 72 \\
\hline & 84 & 55 & 42 & 3 & 8.00 & 7.00 & 8.00 & 8 \\
\hline
\end{tabular}

Outliers determinados para os corpos-de-prova dos ensaios de RCS. 


\section{ANEXO D \\ RESULTADOS DOS ENSAIOS DE RESISTÊNCIA À TRAÇÃO POR COMPRESSÃO DIAMETRAL}


TABELA D1 - Valores de resistência à tração por compressão diametral das misturas solo-cinza pesada e identificação dos outliers.

\begin{tabular}{|c|c|c|c|c|c|c|c|c|c|c|c|c|c|c|c|}
\hline \multirow[b]{2}{*}{ Solo } & \multirow[b]{2}{*}{$\begin{array}{l}\text { Cura } \\
\text { (dias) }\end{array}$} & \multicolumn{3}{|c|}{ Misutras } & \multicolumn{3}{|c|}{ Corpo-de-prova } & \multirow[b]{2}{*}{$\begin{array}{c}\text { Média } \\
(\mathrm{kPa})\end{array}$} & \multirow[b]{2}{*}{$\begin{array}{l}\text { Desvio } \\
\text { Padrão }\end{array}$} & \multirow[b]{2}{*}{ G Maior } & \multirow[b]{2}{*}{ G Menor } & \multirow[b]{2}{*}{ G Crítico } & \multirow[b]{2}{*}{ Y Maior } & \multirow[b]{2}{*}{ Y menor } & \multirow[b]{2}{*}{ Média Adotada (kPa) } \\
\hline & & $\begin{array}{l}\text { Solo } \\
(\%)\end{array}$ & $\begin{array}{c}\text { Cinza } \\
(\%)\end{array}$ & $\begin{array}{l}\text { Cal } \\
(\%)\end{array}$ & $\begin{array}{c}1 \\
(\mathrm{kPa})\end{array}$ & $\begin{array}{c}2 \\
(\mathrm{kPa})\end{array}$ & $\begin{array}{c}3 \\
(\mathrm{kPa})\end{array}$ & & & & & & & & \\
\hline \multirow{12}{*}{ JG } & 0 & 100 & 0 & 0 & 205.17 & 181.06 & 166.02 & 184.08 & 19.75 & 1.07 & 0.91 & 1.00 & 203.83 & 164.33 & 173.54 \\
\hline & 0 & 75 & 25 & 0 & 44.29 & 79.77 & 73.29 & 65.78 & 18.89 & 0.74 & 1.14 & 1.00 & 84.68 & 46.89 & 76.53 \\
\hline & 0 & 65 & 35 & 0 & 39.28 & 34.02 & 47.27 & 40.19 & 6.67 & 1.06 & 0.92 & 1.00 & 46.86 & 33.52 & 36.65 \\
\hline & 0 & 55 & 45 & 0 & 4.40 & 8.92 & 11.34 & 8.22 & 3.52 & 0.89 & 1.08 & 1.00 & 11.74 & 4.70 & 10.13 \\
\hline & 28 & 100 & 0 & 0 & 128.11 & 151.66 & 94.31 & 124.69 & 28.83 & 0.94 & 1.05 & 1.00 & 153.52 & 95.87 & 139.89 \\
\hline & 28 & 75 & 25 & 0 & 41.21 & 27.33 & 45.27 & 37.94 & 9.41 & 0.78 & 1.13 & 1.00 & 47.34 & 28.53 & 43.24 \\
\hline & 28 & 65 & 35 & 0 & 29.30 & 24.25 & 25.04 & 26.20 & 2.72 & 1.14 & 0.72 & 1.00 & 28.91 & 23.48 & 24.65 \\
\hline & 28 & 55 & 45 & 0 & * & 24.25 & 19.58 & 21.92 & 3.30 & 0.71 & 0.71 & 1.00 & 25.22 & 18.61 & 21.92 \\
\hline & 84 & 100 & 0 & 0 & 110.02 & 120.40 & 116.00 & 115.47 & 5.21 & 0.95 & 1.05 & 1.00 & 120.68 & 110.26 & 118.20 \\
\hline & 84 & 75 & 25 & 0 & 36.64 & 33.00 & 34.00 & 34.55 & 1.88 & 1.11 & 0.82 & 1.00 & 36.43 & 32.67 & 33.50 \\
\hline & 84 & 65 & 35 & 0 & 19.22 & 20.24 & 22.04 & 20.50 & 1.43 & 1.08 & 0.90 & 1.00 & 21.93 & 19.07 & 19.73 \\
\hline & 84 & 55 & 45 & 0 & 21.60 & 22.46 & 19.08 & 21.05 & 1.76 & 0.80 & 1.12 & 1.00 & 22.80 & 19.29 & 22.03 \\
\hline \multirow{12}{*}{ SG } & 0 & 100 & 0 & 0 & 84.40 & 91.42 & 80.60 & 85.47 & 5.49 & 1.08 & 0.89 & 1.00 & 90.96 & 79.98 & 82.50 \\
\hline & 0 & 75 & 25 & 0 & 28.43 & 27.77 & 20.47 & 25.56 & 4.42 & 0.65 & 1.15 & 1.00 & 29.97 & 21.14 & 28.10 \\
\hline & 0 & 65 & 35 & 0 & 14.64 & 20.04 & 17.42 & 17.37 & 2.70 & 0.99 & 1.01 & 1.00 & 20.07 & 14.67 & 18.73 \\
\hline & 0 & 55 & 45 & 0 & 21.56 & 13.28 & 11.44 & 15.43 & 5.39 & 1.14 & 0.74 & 1.00 & 20.82 & 10.04 & 12.36 \\
\hline & 28 & 100 & 0 & 0 & 91.75 & 71.60 & 51.42 & 71.59 & 20.17 & 1.00 & 1.00 & 1.00 & 91.76 & 51.42 & 71.59 \\
\hline & 28 & 75 & 25 & 0 & 43.15 & 30.29 & 51.76 & 41.73 & 10.80 & 0.93 & 1.06 & 1.00 & 52.54 & 30.93 & 47.46 \\
\hline & 28 & 65 & 35 & 0 & 28.35 & 24.74 & 17.97 & 23.69 & 5.27 & 0.88 & 1.08 & 1.00 & 28.96 & 18.42 & 26.55 \\
\hline & 28 & 55 & 45 & 0 & * & 15.32 & 3.82 & 9.57 & 8.13 & 0.71 & 0.71 & 1.00 & 17.70 & 1.44 & 9.57 \\
\hline & 84 & 100 & 0 & 0 & 94.08 & 73.62 & 66.90 & 78.20 & 14.16 & 1.12 & 0.80 & 1.00 & 92.36 & 64.04 & 70.26 \\
\hline & 84 & 75 & 25 & 0 & 54.48 & 50.72 & 54.42 & 53.21 & 2.15 & 0.59 & 1.15 & 1.00 & 55.36 & 51.05 & 54.45 \\
\hline & 84 & 65 & 35 & 0 & 30.68 & 33.12 & 22.42 & 28.74 & 5.61 & 0.78 & 1.13 & 1.00 & 34.35 & 23.13 & 31.90 \\
\hline & 84 & 55 & 45 & 0 & 12.24 & 10.02 & 9.58 & 10.61 & 1.43 & 1.14 & 0.72 & 1.00 & 12.04 & 9.19 & 9.80 \\
\hline \multirow{12}{*}{ TM } & 0 & 100 & 0 & 0 & 126.74 & 117.09 & 97.97 & 113.93 & 14.64 & 0.87 & 1.09 & 1.00 & 128.58 & 99.29 & 121.92 \\
\hline & 0 & 75 & 25 & 0 & 14.46 & 15.93 & 12.63 & 14.34 & 1.65 & 0.96 & 1.03 & 1.00 & 15.99 & 12.69 & 15.20 \\
\hline & 0 & 65 & 35 & 0 & 15.75 & 22.26 & 21.08 & 19.70 & 3.47 & 0.74 & 1.14 & 1.00 & 23.17 & 16.23 & 21.67 \\
\hline & 0 & 55 & 45 & 0 & 12.08 & 13.45 & 13.17 & 12.90 & 0.72 & 0.76 & 1.13 & 1.00 & 13.62 & 12.18 & 13.31 \\
\hline & 28 & 100 & 0 & 0 & 95.55 & 99.30 & 73.64 & 89.50 & 13.86 & 0.71 & 1.14 & 1.00 & 103.36 & 75.64 & 97.43 \\
\hline & 28 & 75 & 25 & 0 & 13.63 & 13.29 & 5.01 & 10.64 & 4.88 & 0.61 & 1.15 & 1.00 & 15.52 & 5.76 & 13.46 \\
\hline & 28 & 65 & 35 & 0 & 18.96 & 26.12 & 13.92 & 19.67 & 6.13 & 1.05 & 0.94 & 1.00 & 25.80 & 13.54 & 16.44 \\
\hline & 28 & 55 & 45 & 0 & 17.45 & 12.74 & 10.21 & 13.47 & 3.67 & 1.08 & 0.89 & 1.00 & 17.14 & 9.79 & 11.48 \\
\hline & 84 & 100 & 0 & 0 & 94.08 & 93.62 & 86.48 & 91.39 & 4.26 & 0.63 & 1.15 & 1.00 & 95.65 & 87.13 & 93.85 \\
\hline & 84 & 75 & 25 & 0 & 12.22 & 16.30 & 11.84 & 13.45 & 2.47 & 1.15 & 0.65 & 1.00 & 15.93 & 10.98 & 12.03 \\
\hline & 84 & 65 & 35 & 0 & 32.02 & 31.78 & 40.74 & 34.85 & 5.11 & 1.15 & 0.60 & 1.00 & 39.95 & 29.74 & 31.90 \\
\hline & 84 & 55 & 45 & 0 & 19.56 & 12.10 & 9.80 & 13.82 & 5.10 & 1.12 & 0.79 & 1.00 & 18.92 & 8.72 & 10.95 \\
\hline
\end{tabular}


TABELA D2 - Valores de resistência à tração por compressão diametral das misturas solo-cinza pesada-cal e identificação dos outliers.

\begin{tabular}{|c|c|c|c|c|c|c|c|c|c|c|c|c|c|c|c|}
\hline \multirow[b]{2}{*}{ Solo } & \multirow[b]{2}{*}{$\begin{array}{l}\text { Cura } \\
\text { (dias) }\end{array}$} & \multicolumn{3}{|c|}{ Misutras } & \multicolumn{3}{|c|}{ Corpo-de-prova } & \multirow[b]{2}{*}{$\begin{array}{l}\text { Média } \\
(\mathrm{kPa})\end{array}$} & \multirow[b]{2}{*}{$\begin{array}{l}\text { Desvio } \\
\text { Padrão }\end{array}$} & \multirow[b]{2}{*}{ G Maior } & \multirow[b]{2}{*}{ G Menor } & \multirow[b]{2}{*}{ G Crítico } & \multirow[b]{2}{*}{ Y Maior } & \multirow[b]{2}{*}{ Y menor } & \multirow[b]{2}{*}{$\begin{array}{l}\text { Média Adotada } \\
\qquad(\mathrm{kPa})\end{array}$} \\
\hline & & $\begin{array}{c}\text { Solo } \\
(\%)\end{array}$ & $\begin{array}{c}\text { Cinza } \\
(\%)\end{array}$ & $\begin{array}{l}\text { Cal } \\
(\%)\end{array}$ & $\begin{array}{c}1 \\
(\mathrm{kPa})\end{array}$ & $\begin{array}{c}2 \\
(\mathrm{kPa})\end{array}$ & $\begin{array}{c}3 \\
(\mathrm{kPa})\end{array}$ & & & & & & & & \\
\hline \multirow{12}{*}{ JG } & 0 & 97 & 0 & 3 & 227.46 & 282.04 & 240.81 & 250.10 & 28.45 & 1.12 & 0.80 & 1.00 & 278.56 & 221.65 & 234.14 \\
\hline & 0 & 75 & 22 & 3 & 75.49 & 74.17 & 77.04 & 75.57 & 1.44 & 1.03 & 0.97 & 1.00 & 77.00 & 74.13 & 74.83 \\
\hline & 0 & 65 & 32 & 3 & 48.05 & 50.50 & 37.94 & 45.50 & 6.66 & 0.75 & 1.13 & 1.00 & 52.15 & 38.84 & 49.28 \\
\hline & 0 & 55 & 42 & 3 & 29.39 & 24.89 & 22.92 & 25.73 & 3.32 & 1.10 & 0.85 & 1.00 & 29.05 & 22.42 & 23.91 \\
\hline & 28 & $\overline{97}$ & 0 & 3 & 192.37 & 202.87 & 177.80 & 191.01 & 12.59 & 0.94 & 1.05 & 1.00 & 203.60 & 178.42 & 197.62 \\
\hline & 28 & 75 & 22 & 3 & 103.06 & 104.68 & 103.27 & 103.67 & 0.88 & 1.15 & 0.69 & 1.00 & 104.55 & 102.79 & 103.98 \\
\hline & 28 & 65 & 32 & 3 & 71.34 & 72.88 & 66.56 & 70.26 & 3.30 & 0.80 & 1.12 & 1.00 & 73.56 & 66.96 & 72.11 \\
\hline & 28 & 55 & 42 & 3 & 14.70 & 12.45 & 11.46 & 12.87 & 1.66 & 1.10 & 0.85 & 1.00 & 14.53 & 11.21 & 11.96 \\
\hline & 84 & 97 & 0 & 3 & 158.42 & 163.00 & 160.26 & 160.56 & 2.30 & 1.06 & 0.93 & 1.00 & 162.86 & 158.26 & 160.56 \\
\hline & 84 & 75 & 22 & 3 & 131.12 & 134.00 & 132.02 & 132.38 & 1.47 & 1.10 & 0.86 & 1.00 & 133.85 & 130.91 & 131.57 \\
\hline & 84 & 65 & 32 & 3 & 100.66 & 102.52 & 106.12 & 103.10 & 2.78 & 1.09 & 0.88 & 1.00 & 105.88 & 100.32 & 101.59 \\
\hline & 84 & 55 & 42 & 3 & * & * & * & * & * & * & * & * & * & * & * \\
\hline \multirow{12}{*}{ SG } & 0 & 97 & 0 & 3 & 164.06 & 170.51 & 158.33 & 164.30 & 6.09 & 1.02 & 0.98 & 1.00 & 170.39 & 158.21 & 161.20 \\
\hline & 0 & 75 & 22 & 3 & 50.59 & 52.10 & 47.67 & 50.12 & 2.25 & 0.88 & 1.09 & 1.00 & 52.37 & 47.87 & 51.35 \\
\hline & 0 & 65 & 32 & 3 & 31.30 & 31.18 & 30.38 & 30.95 & 0.50 & 0.69 & 1.15 & 1.00 & 31.45 & 30.45 & 31.24 \\
\hline & 0 & 55 & 42 & 3 & 12.93 & 25.06 & 15.83 & 17.94 & 6.33 & 1.12 & 0.79 & 1.00 & 24.27 & 11.61 & 14.38 \\
\hline & 28 & 97 & 0 & 3 & 179.42 & 141.38 & 157.97 & 159.59 & 19.07 & 1.04 & 0.95 & 1.00 & 178.66 & 140.52 & 149.68 \\
\hline & 28 & 75 & 22 & 3 & 61.43 & 66.27 & 76.63 & 68.11 & 7.77 & 1.10 & 0.86 & 1.00 & 75.88 & 60.34 & 63.85 \\
\hline & 28 & 65 & 32 & 3 & 43.09 & 44.05 & 38.22 & 41.79 & 3.13 & 0.72 & 1.14 & 1.00 & 44.91 & 38.66 & 43.57 \\
\hline & 28 & 55 & 42 & 3 & 53.33 & 50.11 & 60.40 & 54.61 & 5.26 & 1.10 & 0.86 & 1.00 & 59.88 & 49.35 & 51.72 \\
\hline & 84 & 97 & 0 & 3 & 145.02 & 147.78 & 142.28 & 145.03 & 2.75 & 1.00 & 1.00 & 1.00 & 147.78 & 142.28 & 145.03 \\
\hline & 84 & 75 & 22 & 3 & 77.36 & 79.52 & 80.78 & 79.22 & 1.73 & 0.90 & 1.08 & 1.00 & 80.95 & 77.49 & 80.15 \\
\hline & 84 & 65 & 32 & 3 & 57.14 & 59.84 & 67.56 & 61.51 & 5.41 & 1.12 & 0.81 & 1.00 & 66.92 & 56.11 & 58.49 \\
\hline & 84 & 55 & 42 & 3 & 59.64 & 60.94 & 62.08 & 60.89 & 1.22 & 0.98 & 1.02 & 1.00 & 62.11 & 59.67 & 60.89 \\
\hline \multirow{12}{*}{ TM } & 0 & 97 & 0 & 3 & 186.37 & 184.88 & 162.67 & 177.97 & 13.27 & 0.63 & 1.15 & 1.00 & 191.25 & 164.70 & 185.63 \\
\hline & 0 & 75 & 22 & 3 & 43.86 & 46.68 & 52.17 & 47.57 & 4.23 & 1.09 & 0.88 & 1.00 & 51.80 & 43.34 & 45.27 \\
\hline & 0 & 65 & 32 & 3 & 47.92 & 49.99 & 51.78 & 49.90 & 1.93 & 0.97 & 1.02 & 1.00 & 51.83 & 47.96 & 50.89 \\
\hline & 0 & 55 & 42 & 3 & 15.34 & 14.22 & 16.45 & 15.34 & 1.12 & 1.00 & 1.00 & 1.00 & 16.45 & 14.22 & 15.34 \\
\hline & 28 & 97 & 0 & 3 & 175.26 & 156.20 & 157.82 & 163.09 & 10.57 & 1.15 & 0.65 & 1.00 & 173.66 & 152.53 & 157.01 \\
\hline & 28 & 75 & 22 & 3 & 60.86 & 38.54 & 60.74 & 53.38 & 12.85 & 0.58 & 1.15 & 1.00 & 66.23 & 40.53 & 60.80 \\
\hline & 28 & 65 & 32 & 3 & 67.36 & * & 50.22 & 58.79 & 12.12 & 0.71 & 0.71 & 1.00 & 70.91 & 46.67 & 58.79 \\
\hline & 28 & 55 & 42 & 3 & 14.49 & 18.87 & 21.38 & 18.25 & 3.49 & 0.90 & 1.08 & 1.00 & 21.73 & 14.76 & 20.13 \\
\hline & 84 & 97 & 0 & 3 & 139.40 & 140.62 & 140.22 & 140.08 & 0.62 & 0.87 & 1.09 & 1.00 & 140.70 & 139.46 & 140.42 \\
\hline & 84 & 75 & 22 & 3 & 79.88 & 69.10 & 70.34 & 73.11 & 5.90 & 1.15 & 0.68 & 1.00 & 79.01 & 67.21 & 69.72 \\
\hline & 84 & 65 & 32 & 3 & 72.46 & 66.20 & 68.50 & 69.05 & 3.17 & 1.08 & 0.90 & 1.00 & 72.22 & 65.89 & 67.35 \\
\hline & 84 & 55 & 42 & 3 & 29.82 & 30.14 & 30.44 & 30.13 & 0.31 & 0.99 & 1.01 & 1.00 & 30.44 & 29.82 & 30.29 \\
\hline
\end{tabular}

